\title{
CONTAMINATED GROUNDWATER FLOW CONTROL ACROSS AN INVERTED GROUNDWATER DIVIDE WITH THREE GROUNDWATER CONTROL SYSTEMS
}

\author{
by \\ Christopher Eugene Hortert \\ B.A. Environmental Geoscience, Slippery Rock University, 2006
}

\begin{abstract}
Submitted to the Graduate Faculty of the
Kenneth P. Dietrich School of Arts and Sciences in partial fulfillment

of the requirements for the degree of

Master of Science
\end{abstract}

University of Pittsburgh

2016 


\title{
UNIVERSITY OF PITTSBURGH
}

Kenneth P. Dietrich School of Arts and Sciences

This thesis was presented

by

Christopher Eugene Hortert

\author{
It was defended on \\ March 28, 2016 \\ and approved by \\ Anthony Iannacchione, PhD, Associate Professor \\ Bill Harbert, PhD, Professor \\ Committee Chair: Dan Bain, PhD, Assistant Professor
}


Copyright (C) by Christopher Eugene Hortert 2016 


\title{
CONTAMINATED GROUNDWATER FLOW CONTROL ACROSS AN INVERTED GROUNDWATER DIVIDE WITH THREE GROUNDWATER CONTROL SYSTEMS
}

\author{
Christopher Eugene Hortert, M.S. \\ University of Pittsburgh, 2016
}

The potential impacts from legacy, unlined landfills to surrounding hydrological systems are substantial challenges in the management of waste and water quality. Because these landfills do not have passive controls (i.e. liners), groundwater controls (pumping wells, trenches, etc.) can be necessary to minimize impacts. However, the function and interaction of multiple groundwater control devices in combination with complicated hydrogeologic settings are poorly characterized. Most research on groundwater control device interactions relies on simulation experiments and either measures the effectiveness of a system using a limited set of groundwater control devices or focuses on a single aquifer. This thesis examines three groundwater control devices (a slurry wall, a pumping trench, and a pumping well) installed near an active legacy landfill to evaluate changes in the flow of contaminated groundwater off site. This system of control devices was evaluated using monthly water quality data from a spring where changes in water quality were observed prior to installation of the groundwater control system. The water geochemical results indicate that the contaminated groundwater flows primarily through the fractured rock in the ridge (contrary to expectations), and therefore the collection trench is more effective in contaminant flux reductions. The groundwater pumping well, designed to capture contaminated groundwater flow through the coal seams and sandstone, is less effective, likely due to limited transport through the coal aquifers. Although the groundwater control system reduces the amount of contaminated groundwater flow off site, these controls must operate until the landfill is closed and a permanent control (i.e. installation of a clay cap which will reduce infiltration and should result in reduced groundwater elevations) can be installed which may take decades. The results provide fundamental information for future application of groundwater control in complicated field sites. 
$\underline{\text { PAGE }}$

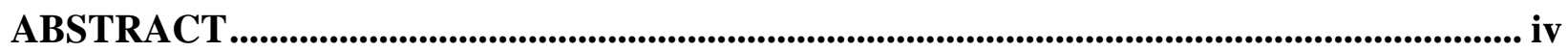

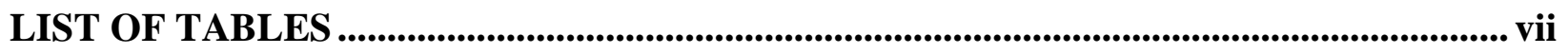

LIST OF FIGURES ........................................................................................................ viii

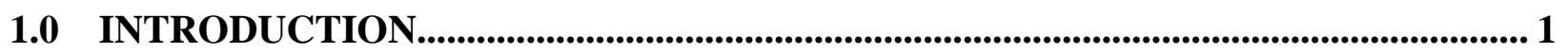

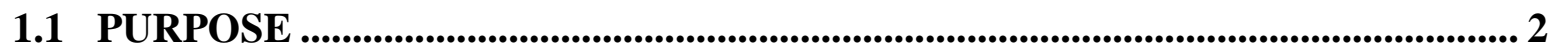

1.2 REVIEW OF PREVIOUS RESEARCH..................................................... 3

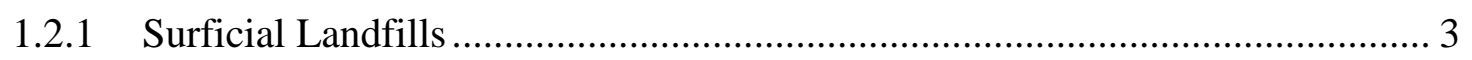

1.2.2 Pumping Trench Groundwater Control ....................................................... 4

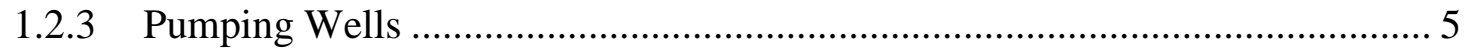

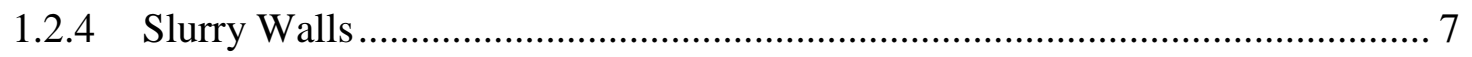

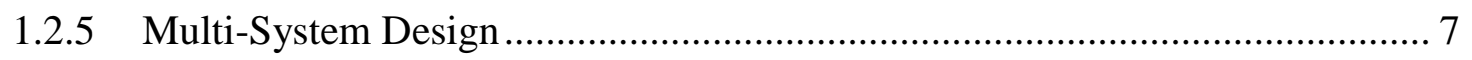

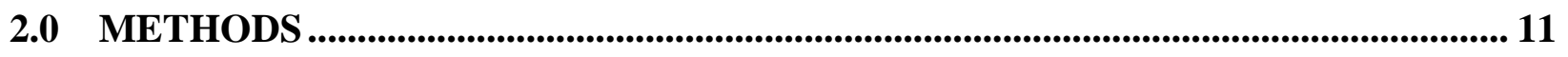

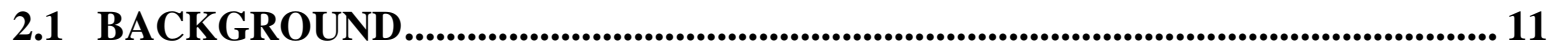

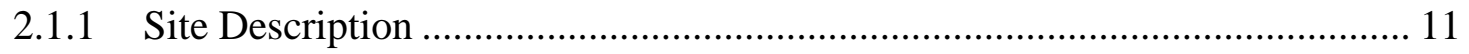

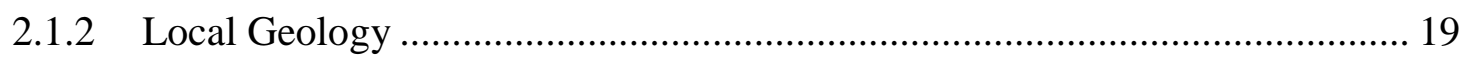

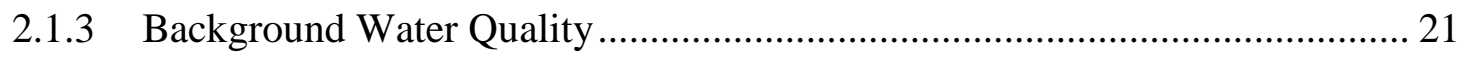

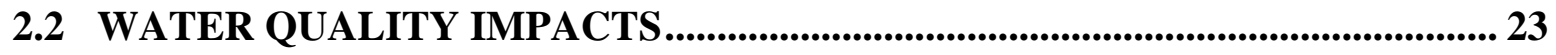

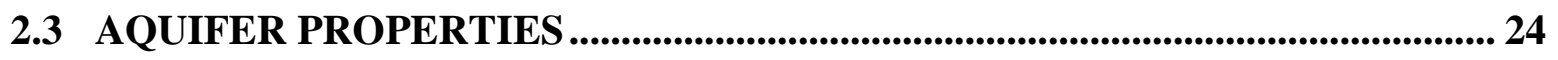

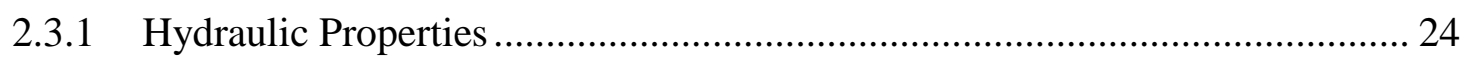

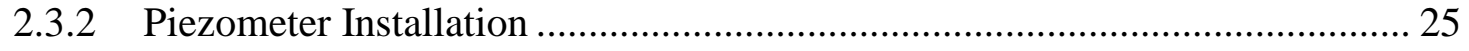

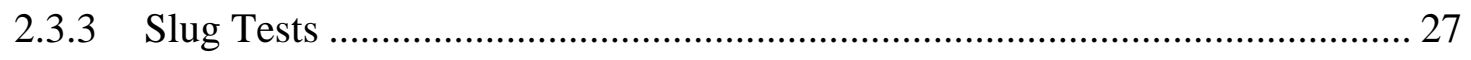

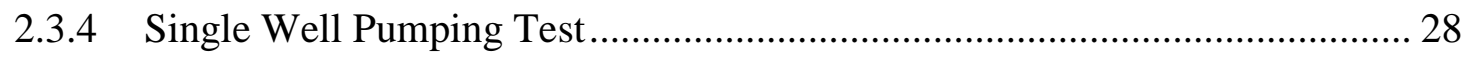

2.3.5 Multi-Well Pumping Test..................................................................... 29

2.4 GROUNDWATER CONTROL INSTALLATIONS ..................................... 31

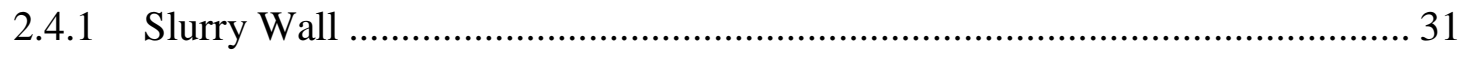

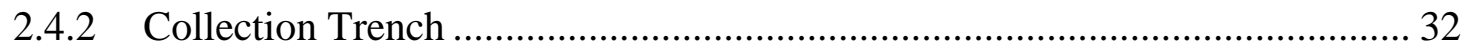

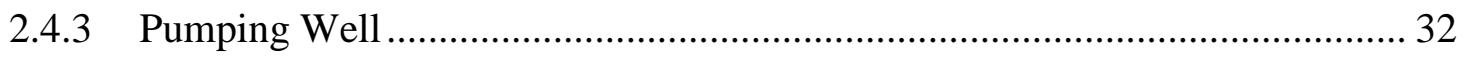




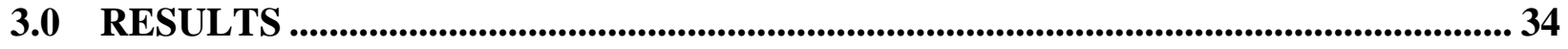

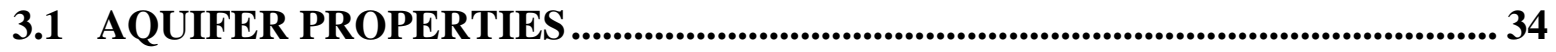

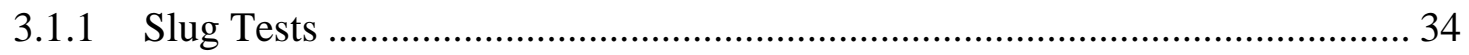

3.1.2 Single Well Pumping Test..................................................................... 35

3.1.3 Multi-Well Pumping Test.......................................................................... 35

3.2 PERTURBATIONS IN GROUNDWATER CONTROL TECHNOLOGIES ..... 40

3.2.1 Pumping Trench .............................................................................. 40

4.0 DISCUSSION OF AQUIFER PROPERTIES AND WATER QUALITY .................. 44

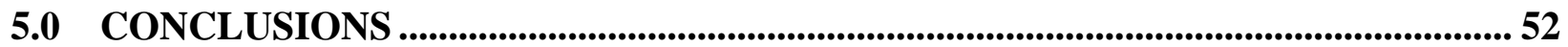

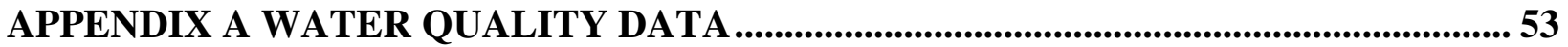

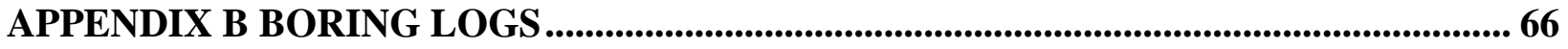

APPENDIX C SLUG TEST AND PUMPING TEST RESULTS...................................... 140

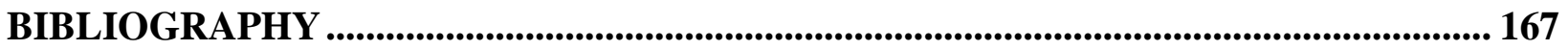




\section{LIST OF TABLES}

Table 1. Water Quality Comparison............................................................................. 22

Table 2. Site Water Quality Compared to Background........................................................ 23

Table 3. Piezometer Construction Details ......................................................................... 26

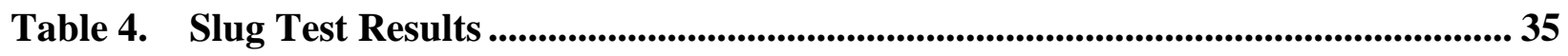

Table 5. Pumping Test Results ........................................................................................ 36

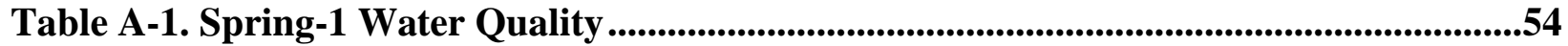

Table A-2. Spring-2 Water Quality ......................................................................................58 


\section{LIST OF FIGURES}

Figure 1. Groundwater Pumping Well Capture Zone........................................................ 6

Figure 2. Pump and Treat Systems with a Slurry Wall.........................................................9

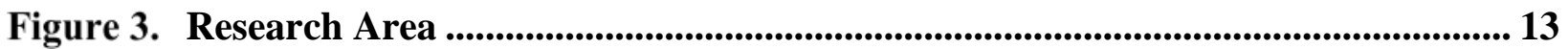

Figure 4. Research Area with Groundwater Controls........................................................... 14

Figure 5. Cross Section A of Research Area ........................................................................... 16

Figure 6. Water Quality at Spring-1 and Spring-2 ..................................................... 18

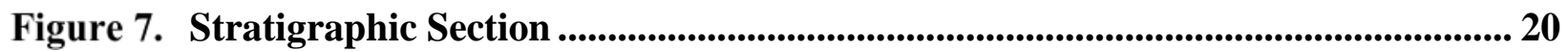

Figure 8. Hydraulic Conductivity Determination .................................................................. 28

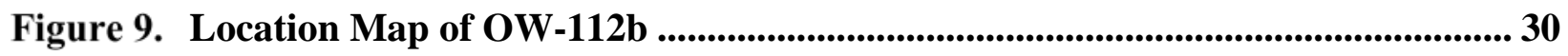

Figure 10. Cross Section A of Research Area ....................................................................................... 37

Figure 11. Cross Section B of Research Area ...................................................................... 38

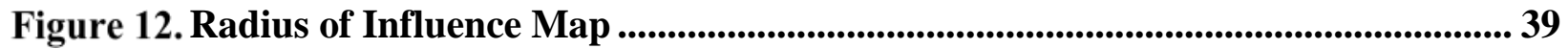

Figure 13. Water Quality at Spring-1 and Spring-2 ..................................................... 41

Figure 14. Spring-2 Water Quality Compared to Groundwater Elevations .......................... 43

Figure 15. Radial Plots of Water Quality-Fall 2012 ........................................................ 49

Figure 16. Radial Plots of Water Quality-Fall 2014................................................................ 50

Figure 17. Sulfate to Alkalinity Comparison .................................................................... 51

Figure B-1 12-10 Boring Log.....................................................................................................6 67

Figure B-2 12-10A Boring Log.................................................................................... 72

Figure B-3 12-10B Boring Log ...................................................................................... 73

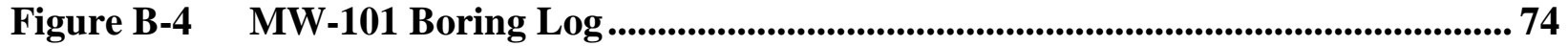

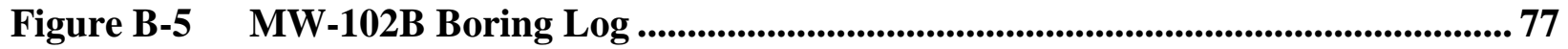

Figure B-6 MW-103A Boring Log .......................................................................................... 84

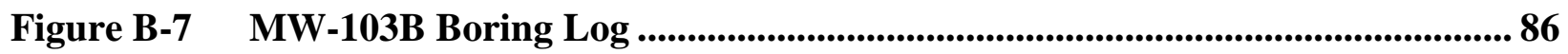

Figure B-8 MW-103C Boring Log ...................................................................................... 92

Figure B-9 MW-105 Boring Log .......................................................................................... 99 
Figure B-10 MW-105B Boring Log ........................................................................................ 101

Figure B-11 MW-107A Boring Log ............................................................................................ 105

Figure B-12 MW-107B Boring Log ................................................................................................. 107

Figure B-13 MW-107C Boring Log ............................................................................................ 113

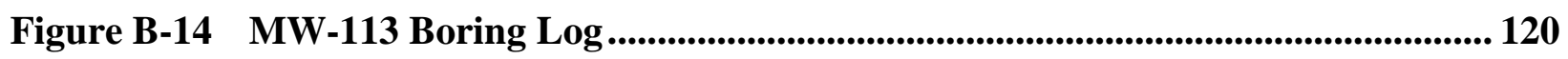

Figure B-15 MW-114A Boring Log .......................................................................................... 122

Figure B-16 MW-114B Boring Log ............................................................................................ 125

Figure B-17 MW-116B Boring Log ............................................................................................. 131

Figure B-18 OW-112B Boring Log.......................................................................................... 137

Figure C-1 12-10 Pumping Test ........................................................................................................ 141

Figure C-2 12-10A Pumping Test ............................................................................................ 142

Figure C-3 12-10B Pumping Test.......................................................................................... 143

Figure C-4 MW-103B Pumping Test.............................................................................................. 144

Figure C-5 MW-103B Slug Test................................................................................................... 145

Figure C-6 MW-102B Pumping Test........................................................................................... 146

Figure C-7 MW-105B Pumping Test................................................................................ 147

Figure C-8 MW-107B Slug Test.......................................................................................... 148

Figure C-9 MW-116B Slug Test............................................................................................. 149

Figure C-10 OW-112B Pumping Test................................................................................................. 150

Figure C-11 12-10A Slug Test ........................................................................................................ 151

Figure C-12 P-1(50) Pumping Test ............................................................................................... 152

Figure C-13 P-1(150) Pumping Test ......................................................................................... 153

Figure C-14 P-1(220) Slug Test ....................................................................................................... 154

Figure C-15 MW-101 Slug Test...................................................................................................... 155

Figure C-16 MW-103a Slug Test.................................................................................................... 156

Figure C-17 MW-103c Slug Test...................................................................................................... 157

Figure C-18 MW-105 Slug Test................................................................................................. 158 
Figure C-19 MW-107a Slug Test............................................................................................... 159

Figure C-20 MW-107b Slug Test .................................................................................................... 160

Figure C-21 MW-107c Slug Test....................................................................................................... 161

Figure C-22 MW-110 Slug Test....................................................................................................... 162

Figure C-23 MW-111 Slug Test................................................................................. 163

Figure C-24 MW-113 Slug Test........................................................................................................... 164

Figure C-25 MW-114A Slug Test..................................................................................................... 165

Figure C-26 MW-114B Slug Test.................................................................................................... 166 


\subsection{INTRODUCTION}

In 2013, the US population, on average, produced 2 kilograms of trash per day per person (USEPA, 2015). This average has increased from an average of 1.2 kilograms per day per person in 1960 (USEPA, 2015). During this period, waste disposal methods have varied, but historically one of the most common methods has been landfill disposal. Landfilling of waste is a common waste management practice and is one of the cheapest methods for organized waste management in most of the world (El-Fadel et al, 1997). In 1983 the United States Environmental Protection Agency (USEPA) inventoried approximately 2,079 open dumps (EPA, 1983). Open dumps had little to no government oversight monitoring their construction or operation. Poorly designed landfills without groundwater control devices can contaminate groundwater, and groundwater contamination is the most commonly reported danger to human health from landfills (Odunlami, 2012). Numerous studies have shown that unlined landfills contaminate groundwater (LaMaskin, 2003; Reddy, 2011; Yadav, 2014).

Newer landfills generally rely on engineered control barriers, that is, barriers constructed from a combination of earthen and polymeric liners, designed to slow the rate of contaminant released to the environment (Yeboah, 2011). Newer landfills are regulated by the United States Environmental Protection Agency (USEPA), or by the state environmental agency where they operate. Legacy open dumps, which started operations before the Solid Waste Disposal Act of 1965 when governmental oversight began, are much more likely to become sources of groundwater contamination. These landfills cannot be retroactively fitted with liners, so groundwater control devices are likely instrumental in groundwater contamination prevention.

Landfills with no liner system cause water to pool and the water levels in the landfill can impact groundwater quality, recharge area, geomorphic changes, and storage of an aquifer. The primary effect of water pooling in landfills is on flow direction and groundwater levels. For example, changes in groundwater flow direction were observed following the construction of Lake Diefenbaker on the Saskatchewan River (Schmid, 2003). Prior to construction of the dam, groundwater flow direction was toward the river valley in a generally flat topography. After the reservoir was filled, the flow direction reversed and generally flowed away from the river valley 
up to 5 kilometers upstream of the dam. Additionally, the water levels in the dam caused groundwater levels in the bedrock aquifer through both increased infiltration and the rise in hydraulic base level (Wildi, 2010). In general, this rise in groundwater levels causes the changes in groundwater flow direction. Increased water elevations in the groundwater aquifer were observed in the Riverhurst section of the Lake Diefenbaker dam. When water levels in the lake rose by $40 \mathrm{~m}$, water levels in the bedrock aquifer were observed to rise by $3 \mathrm{~m}$ to $33 \mathrm{~m}$ depending on the section of the lake (Schmid, 2003). Landfills and dams can dramatically change the groundwater levels and flow direction in aquifers. These altered groundwater flow dynamics generally complicate groundwater control efforts.

Groundwater control devices are installed to capture/prevent movement of contaminated groundwater. These devices can be installed as separate systems or combined at sites where a higher volume of groundwater needs to be controlled and one system alone is not likely to effectively control groundwater flow. Groundwater control is achieved by both passive and active systems. Passive interceptor trenches prevent contaminant migration offsite without causing cones of depression and intervening zones of low velocity, in which contaminants linger (EPA, 1989). Similarly, passive slurry walls are vertical barriers comprised of a material with a low permeability constructed downgradient of a contamination source. This low permeable material prevents contaminated groundwater from flowing downgradient and allows additional time to extract the contaminated groundwater. In contrast, an active system like a groundwater pumping well continuously pumps groundwater out of the system, creating a cone of depression in the groundwater table. The cone of depression funnels contaminated groundwater to the pumping well and prevents continued contaminant flow downstream through the aquifer. Whether passive or active, groundwater controls require careful design and evaluation to ensure they are effective.

\subsection{PURPOSE}

This research examines how three groundwater control devices interact and the implications for prevention of contaminated groundwater flow from a legacy landfill. Without these controls to manage the contaminated groundwater, the water will likely flow from the landfill and down gradient to other downstream receptors. This task is complicated by elevated groundwater levels that have overtopped groundwater divides, removing natural barriers that 
would prevent leachate from flowing offsite under normal groundwater elevations. The resulting flow has impacted groundwater and surface water, creating the need for groundwater control. Three groundwater control devices (a groundwater pumping trench, groundwater pumping well, and slurry wall,) were installed and this study will use water chemistry at a spring to evaluate the effectiveness of these controls in the prevention of groundwater flow offsite. Groundwater control devices are typically installed to control groundwater in a single aquifer system and interactions among multiple control devices installed to address complicated aquifer systems are rare to nonexistent. Some studies have examined the effectiveness of multiple groundwater control systems with models (Bayer 2004, Bayer 2006, Avci 1992). However, the research presented in this study is one of the only to evaluate these systems through field measurements. The results provide fundamental information for future application of groundwater control in complicated field sites.

\subsection{REVIEW OF PREVIOUS RESEARCH}

\subsubsection{Surficial Landfills}

When disposing of solid waste, the most common practice is surficial disposal. This type of disposal generally relies on engineered control barriers, that is, barriers constructed from a combination of earthen and polymeric liners, designed to slow the rate of contaminant releases to the surrounding environment (Yeboah, 2011). In particular, these engineered designs minimize liquid flow through the solid waste and the potential mobilization of leached material into local groundwater. Historically, unregulated (i.e. no environmental oversight from a regulatory agency) waste dumps were frequently placed in naturally occurring, low lying surface depressions, and typically were not lined (Yeboah, 2011). Furthermore, additional volume for waste disposal is often added during landfill operation through the construction of dikes around the surface impoundment (Yeboah, 2011). Legacy landfills had little or no controls installed when constructed, therefore these landfills are much more likely to contaminate groundwater. Ultimately this contamination from legacy landfills has to be addressed with more complicated groundwater control strategies. 


\subsubsection{Pumping Trench Groundwater Control}

One of the simplest and most effective configurations for a passive interceptor trench is a linear trench, installed perpendicular to groundwater flow, spanning the maximum width of a hydraulically up gradient contaminant plume (Hudak, 2005). The pumping trench is backfilled with sand or gravel (McMurtry and Elton, 1985), and groundwater that collects in the trench is pumped to a treatment plant. This type of system utilizes prevailing groundwater flow which requires less energy and maintenance than pumping groundwater at several locations to the land surface, treating it, and injecting it back into an aquifer. In some cases, installing a collection trench directly downgradient of the contamination source is not feasible due to property access limitations or complicated plume structures. Fundamentally, the effectiveness of the pumping trench is dependent on the boundary conditions at the site (Avci, 1992). The primary boundary condition identified by Avci (1992) is the impermeable layer under the aquifer. The pumping trench requires the trench to span entire depth of the aquifer. This configuration is not always feasible, particularly when aquifer may be too thick for a trench to be installed across its entire depth.

Avci (1992) examined several scenarios for an interceptor trench near a lake. The goal was to use models to determine how to prevent contaminated groundwater from flowing into the lake. Avci (1992) used measured data from the lake site to populate the simulations including the baseline scenario which used a collection trench next to a lake. Numerical and analytical models were then used to simulate different scenarios and predict if hydraulic barriers in conjunction with the interceptor trench were more effective at capturing contaminated groundwater than the interceptor trench alone. The second scenario simulated the impact of changing lake water levels. When the water levels decreased in the lake, the amount of water that could be removed with the pumping trench decreased and reduced treatment effectiveness. The third scenario examined the impact of varying aquifer thickness. When the thickness of the aquifer increased the aquifer transmissivity increased and caused a smaller drawdown from the pumping trench. This allowed more groundwater to flow past the pumping trench. The fourth scenario examined the impact of a partially penetrating impermeable flow boundary. This scenario had a slurry wall down gradient of the interceptor trench and upgradient of the lake. In this case, the same amount of groundwater was predicted to flow to the interceptor trench as during baseline conditions. Avci (1992) determined that the use of simulations and models were a quick way to establish initial interceptor 
trench effectiveness using assumptions regarding boundary conditions, but field tests are required to determine how actual boundary conditions will influence the interceptor trench.

Hudak (2005) looked at the most effective size and set back distance of an interceptor trench. The further the interceptor trench is from the contaminated area, the wider the trench size and longer the time period necessary to capture the contaminant plume. Hudak (2005) suggests that interceptor trenches oriented perpendicularly to regional groundwater flow should be located close to the leading tip of a contaminant plume and be slightly wider than the maximum width of the plume. This trench configuration is not always feasible due to the arrangement of local topography or the contaminant plume. For example, if the contaminant plume is under a building, a trench likely cannot be installed at the leading tip of the plume. Or, if a contamination source is too wide, installation of an interceptor trench may be prohibitively expensive. Hudak (2005) determined that because wider trenches and farther setbacks increased capture time, quicker recovery was possible if a shorter setback distance could be implemented.

\subsubsection{Pumping Wells}

Pump-and-treat is the most widely used remediation technology for groundwater contamination. Pump-and-treat has been used both as a stand-alone treatment system and in conjunction with complementary technologies. Conventional pump-and-treat methods focus on the extraction of contaminated groundwater to the surface for subsequent treatment. Such systems have been used in about $75 \%$ of Superfund cleanup actions where groundwater was contaminated (NRC, 1994). The treated groundwater may be re-injected into the subsurface or discharged into a receiving water body or a municipal wastewater collection system (Damera, 2007).

An important design objective of a groundwater extraction system may be the hydraulic control of groundwater to prevent offsite migration of the contaminant plume during reclamation efforts. Properly located extraction wells can remove water from the aquifer by creating a capture zone for migrating contaminants. As water is extracted, a capture zone curve develops upstream from the well (Figure 1). Groundwater inside the capture zone is extracted by the well, while the water outside is not (Damera, 2007). The figure below shows an idealized two-dimensional capture 
zone envelope for a well extending the entire depth of an aquifer and pumping at a constant rate, or head value, to extract groundwater equally at all levels (Damera, 2007).

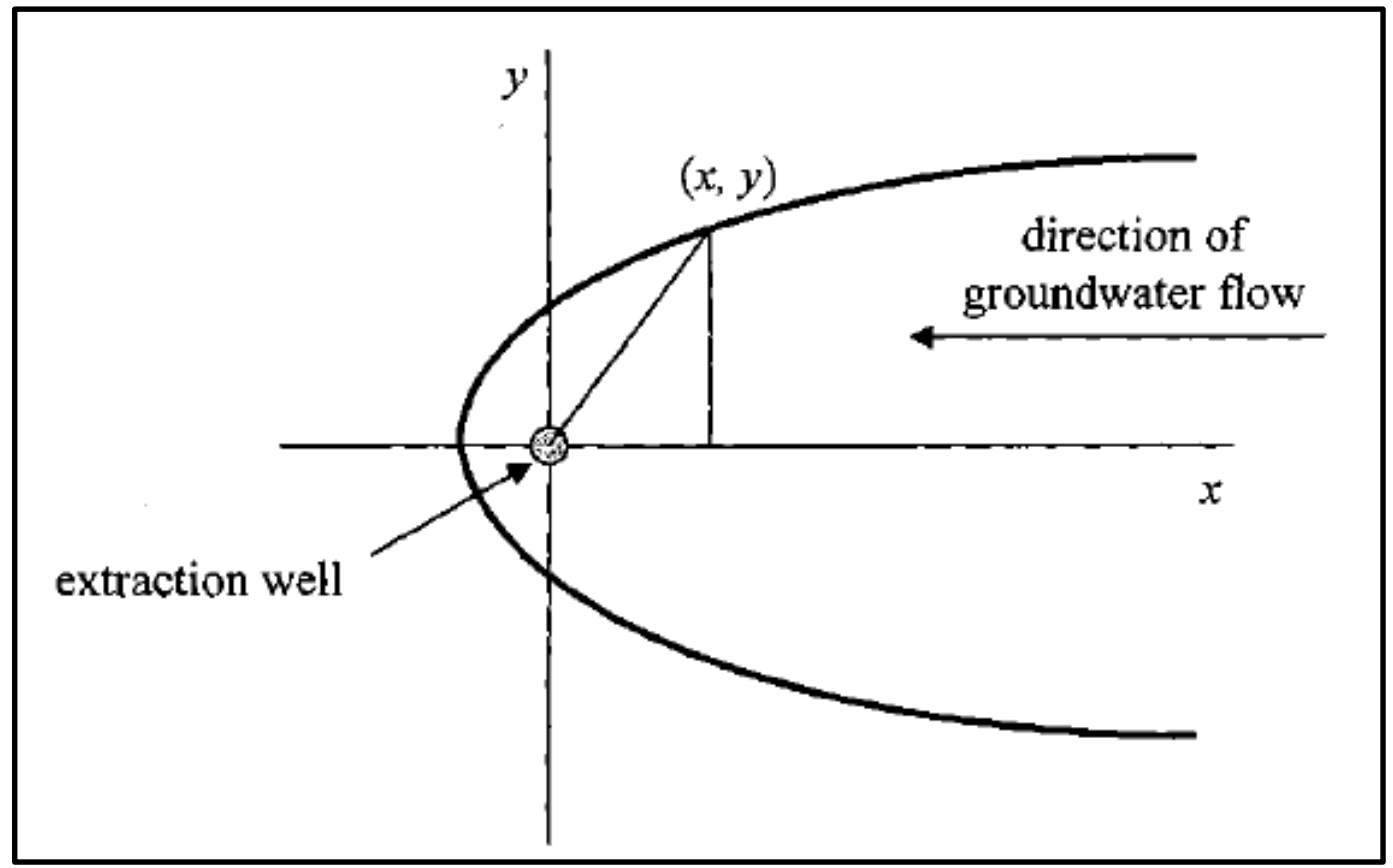

Figure 1. Groundwater Pumping Well Capture Zone

(Damera, 2007)

The objective of many pump-and-treat systems is to lower groundwater contamination concentration below cleanup standards, ultimately allowed the pumping system to be shut down. In some cases, the source of the contamination cannot be completely removed and pumping is required for the foreseeable future.

Duda (2014) examined the water chemistry records of 46 groundwater pumping wells at one of the largest mine tailings disposal sites in Poland to determine reductions in groundwater chloride, sodium, calcium, and sulfate concentrations. Duda (2014) sought to determine a new quantitative criterion for evaluating drainage barrier effects on contaminant transport reduction, and use the criterion to assess pumping well influences on groundwater protection. A material budget approach was used to determine the flux of chloride, sodium, calcium, and sulfate off site and thereby evaluate the effectiveness of the pumping wells. Additional pumping wells were installed until the network surrounded the entire facility and a hydraulic divide between the site and downgradient receptors was created. The network of pumping wells was effective at capturing 
contaminated groundwater that flowed off site. However, not all wells removed contaminated groundwater equally. Duda (2014) found wells that were positioned in preferential groundwater pathways removed the bulk of the contaminated groundwater.

\subsubsection{Slurry Walls}

Vertical barriers are constructed by digging a trench and backfilling it with a slurry-type mixture of water, soil, and bentonite clay. These barriers are keyed into a low-permeability layer such as clay or bedrock (Fetter, 2001). Cutoff walls profoundly alter groundwater flow fields, increasing pumping well efficiency in contaminated groundwater removal. Slurry walls primarily control seepage flow. Slurry walls are now being installed around landfills to prevent contaminant migration off site (Hudak, 2004). Fine sediment content of native soils controls the initial permeability (i.e., more fines, less permeable). As the trench is excavated the materials are mixed and pumped back into the excavation to prevent cave ins. Davis (1988) has shown that the higher the amount of bentonite in the slurry mixture, the lower the hydraulic permeability is of the wall. Davis (1988) also shows that hydraulic permeability varies minimally among the different types of bentonite. The bentonite expands the slurry mixture and minimizes macropore formation that can reduce the effectiveness of the slurry wall. Moreover, if cracking does occur during dry periods, the bentonite will re-expand once the system gets wets again, swells up and reseals. Slurry walls, while effective, require relatively specialized aquifer and plume geometries to be effective in isolation.

\subsubsection{Multi-System Design}

Sometimes a contamination source is too large or the aquifer system too complicated for a single groundwater control system to be effective. In these cases, multiple groundwater control systems can be installed in tandem to control the groundwater flux. However, these systems will interact and can cause unexpected flow patterns.

Bayer (2004) examined the potential of partial containment strategies to reduce the pumping rate required for the pump-and-treat measure. This work used MODFLOW (McDonald and Harbaugh 1988) to conduct simulation experiments. 
Five scenarios were examined (Figure 2);

1. A traditional pump-and-treat system downgradient of the contaminated area (Figure 2A)

2. A hydraulic barrier upgradient of the contaminated area, and the pumping well downgradient of the contaminated area (Figure 2B)

3. A hydraulic barrier downgradient of the contaminated area, and upgradient of the pumping well (Figure 2C)

4. A hydraulic barrier upgradient of the contaminated area, a hydraulic barrier downgradient of the contaminated area, and the pumping well downgradient of both hydraulic barriers and the contaminated area (Figure 2D)

5. A hydraulic barrier upgradient and on both sides of the contaminated area parallel to groundwater flow direction, and the pumping well down gradient of the contaminated area (Figure 2E).

Bayer (2004) determined that combinations of barriers and pumping wells (Figure 2D and 2E) were the most effective at capturing groundwater flow from the contaminated area. When barrier widths are twice the width of the contaminated area, pumping rates from the pumping well can be reduced by $25 \%$ to $50 \%$ compared to a standard pump-and-treat system (Bayer, 2004). While multiple flow controls seem to be promising in terms of improving flow control, these simulated systems focus on relatively simple field conditions. 


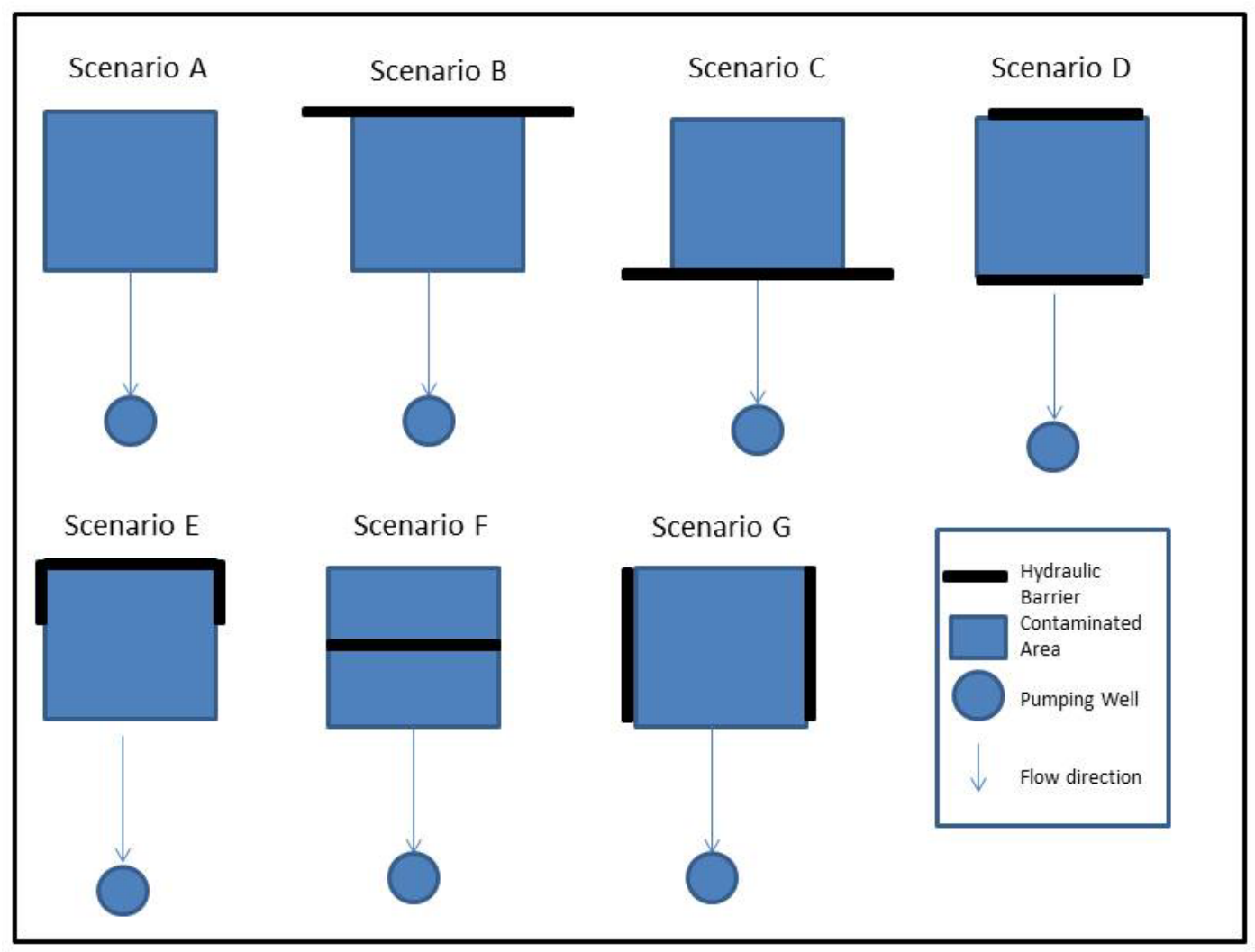

Figure 2. Pump and Treat Systems with a Slurry Wall

Showing 7 different types of pump and treat systems with a slurry wall installed at different locations in respect to the contamination zone.

Bayer (2006) built on this simulation experiment to incorporate uncertainty in the regional flow direction and highly heterogeneous aquifer transmissivity distributions into the simulation experiments. These simulations assume that the operating costs for a pumping system are directly proportional to pumping rates (Bayer, 2006). System designs requiring the minimal pumping rates were therefore the most economical to operate. This study analyzed two additional well-barrier scenarios (Bayer 2206):

1. A hydraulic barrier through the center of the contaminated zone perpendicular to groundwater flow, and the pumping well downgradient of the contaminated area (Figure 2F)

2. Two hydraulic barriers on both sides of the contaminated area and parallel to groundwater flow with the pumping well downgradient of the contaminated area (Figure 2G). 
Heterogeneous aquifer transmissivity was simulated with a Monte Carlo approach; 500 random aquifer realizations were generated with an unconditional sequential Gaussian Simulation (SGS). The SGS is used to estimate probability distributions of aquifer transmissivities. A 3 dimensional transmissivity model was created for each realization, and the minimal pumping rate required for capture of the contaminant plume was evaluated for each scenario. All of the 500 simulated aquifers indicated that pairing a hydraulic barrier with a pumping well would reduce the pumping rate in the well and still capture the contaminated groundwater flow when compared to the standalone pump-and-treat systems. Further, even if groundwater flow direction was poorly predicted and the system was not directly downgradient of the contaminant source, the hydraulic barrier still improved system efficiency. The study found that containment on both the up and down gradient side of the contamination and a downstream pumping well (Figure 2D) reduced the pumping rate necessary to capture the contaminated groundwater flow by $80 \%$.

In the case of unlined landfills with leachable contaminants, the question is not if groundwater contamination will occur, but how much will the landfill impact groundwater quality. Large, unlined landfills generally will require a multi-approach system to minimize contaminant flux from the landfill. If the landfill is too large for a groundwater capture system that surrounds the entire area or local aquifers too thick to effectively install a barrier, a focused approach can be employed to capture contaminated groundwater flow through preferential pathways. However, field-scale data from this type of system is rare, limiting our ability to assess redundant systems used to control large contaminant sources. This research examines a three system approach designed to prevent contaminated groundwater from migrating off site through complicated strata geology. This research will help determine if a multi-approach system is effective, and what parts of the system are most effective so that those components can be incorporated into future system design. 


\subsection{METHODS}

\section{$2.1 \quad$ BACKGROUND}

\subsubsection{Site Description}

The research area (Site) for this study is in Western Pennsylvania. The Site is an unlined, solid waste landfill located in a former stream valley. The eastern and western sides are bounded by ridges. The north side is bounded by an earthen dam. Due to the Site configuration within valley walls, dikes typically constructed around a landfill were not installed. This research focuses on a portion of the Site on the eastern ridge (Figure 3). The ridge acts as a local groundwater divide with two coal seams (Brush Creek and Mahoning) running nearly horizontal through the ridge (Figure 3). Disposal at the landfill does not occur continuously across available landfill area. Rather, disposal occurs in one section of the landfill for 1-3 months. This system of varied disposal areas ensures that one section of the landfill does not have a large mound that rising higher than the rest of the site.

Prior to the disposal of waste, we assume that groundwater flowed in both directions from the ridge (northeast toward Spring-2 and southwest toward the present day landfill, Figure 3). However, once the groundwater levels in the impoundment rose higher than the bedrock aquifer, groundwater flowed predominantly toward the northeast and out of the landfill. Groundwater elevation data for the bedrock aquifer on the ridge prior to solid waste disposal does not exist, however, the effects of the solid waste on the groundwater table are reasonable assumptions though they that cannot be confirmed with available data. Springs are common along coal seam outcrops on the eastern side of the ridge. In particular, two specific springs, Spring-1 and Spring-2, were examined for this study. In 2012 groundwater levels in the research area exceeded an expected tipping point (i.e. groundwater levels rose above the base of the fractured bedrock zone) and concentration of chloride, sulfate, calcium, and magnesium increased in Spring-2. These concentrations peaked in October 2012. At this point in time waste disposal was redirected to other

portions of the landfill. During this period of disposal distant from the ridge, groundwater levels 
returned to elevations below the fractured bedrock. Likewise, following this drop in groundwater elevation, spring water chemistry returned to concentrations observed prior to October 2012.

Following the period of elevated $\mathrm{Cl}, \mathrm{SO}_{4}, \mathrm{Ca}, \mathrm{Mg}$ concentrations in Spring-2, it was determined that groundwater flow controls would be necessary to prevent additional groundwater contamination through the saddle in the ridge (Figure 3) during future periods of waste disposal near the research area. 


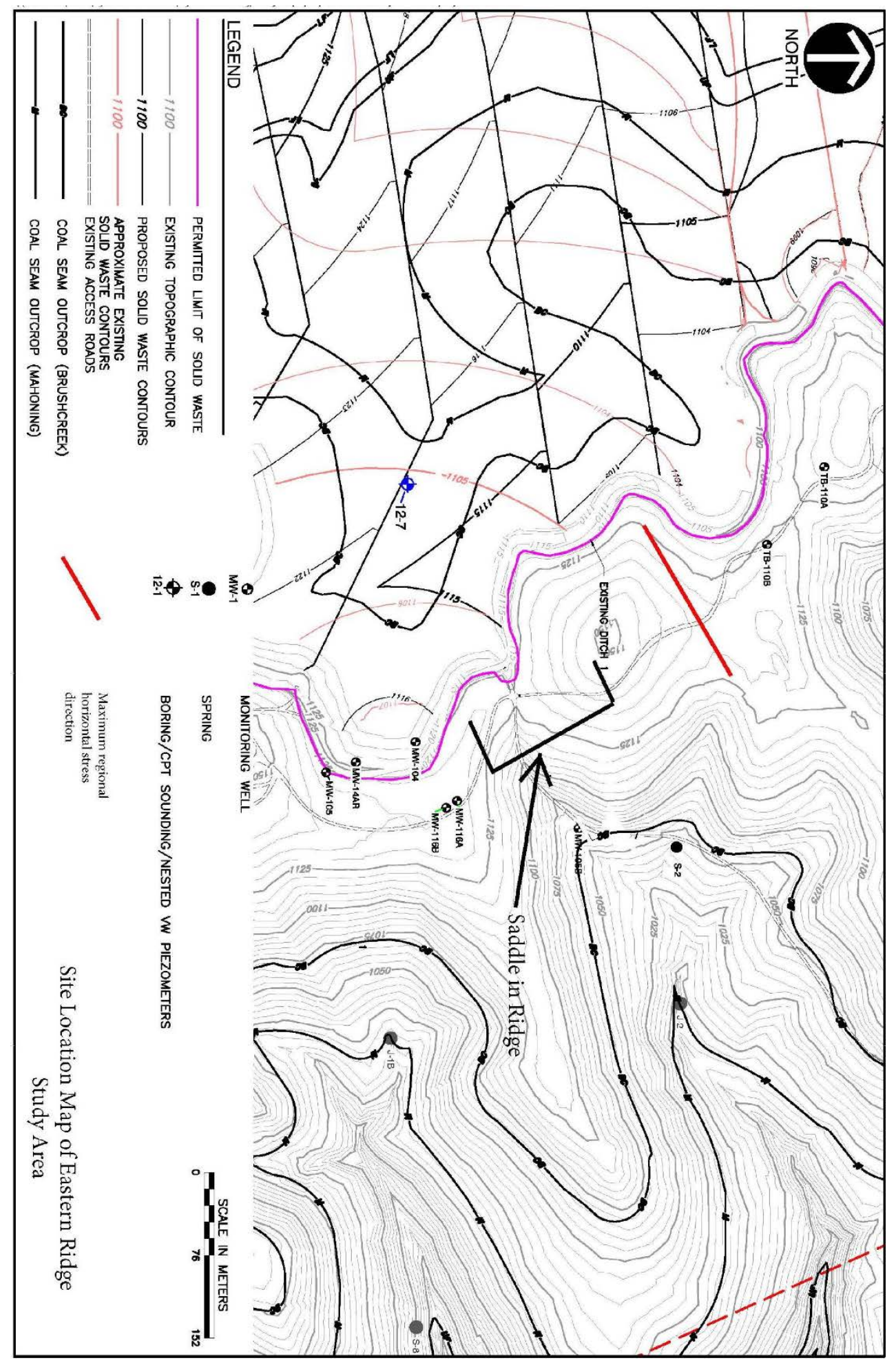

Figure 3. Research Area

Research Area showing the saddle in the ridge. 


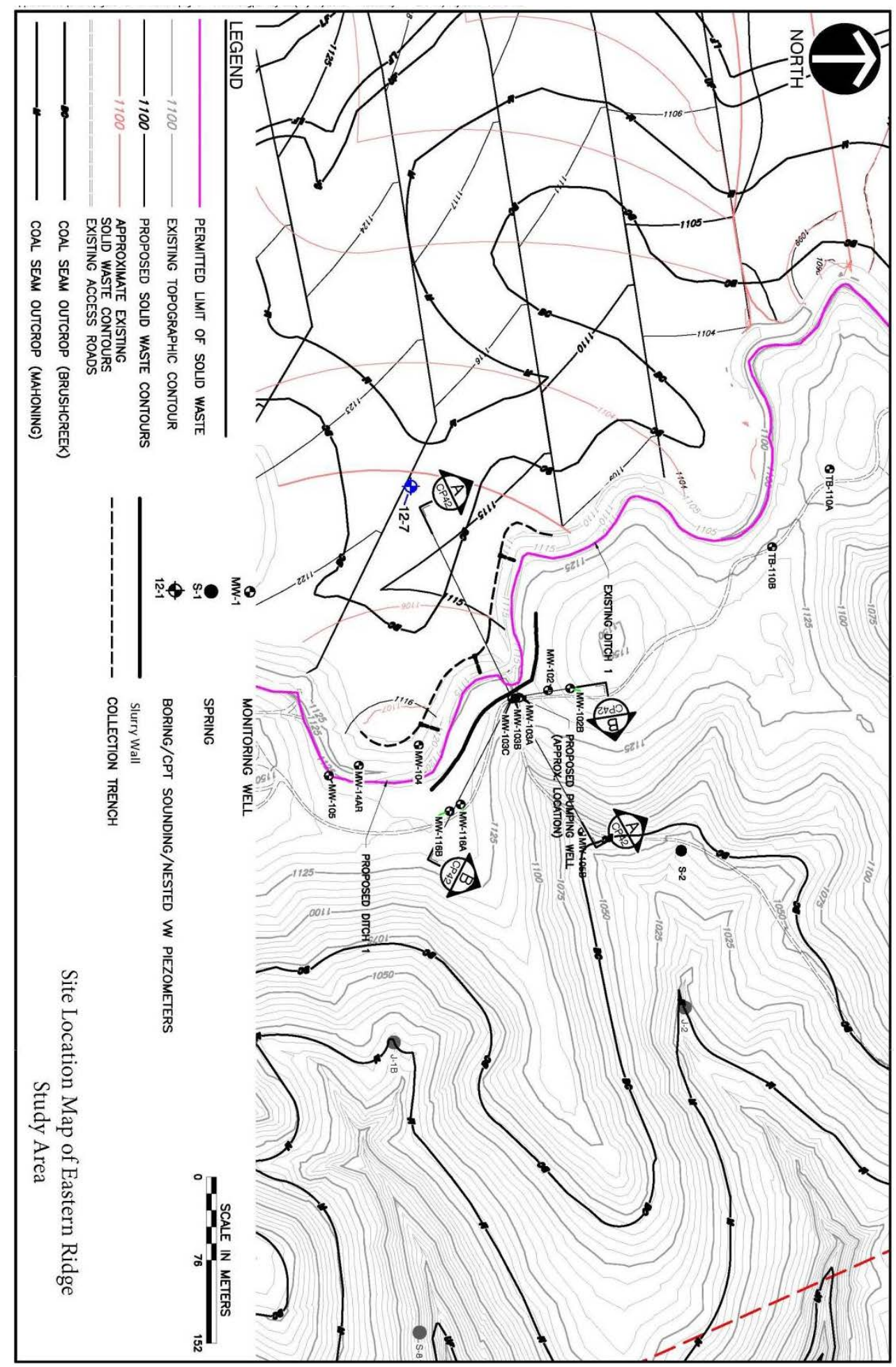

Figure 4. Research Area with Groundwater Controls

Site location for study area showing the coal seam outcrops, solid waste limits, groundwater monitoring wells and spring sampling locations. 
The initial plan was to install groundwater pumping wells along the saddle in the ridge. However, it became clear that this system would not cost effectively control groundwater flow in the area. The second plan involved only installing a slurry wall to act as a hydraulic barrier. A slurry wall would only be effective if it could completely prevent groundwater flow through the ridge. With plans for continued disposal in the landfill, the groundwater elevation would also continue to rise, requiring either a pumping well or collection trench to work in conjunction with the slurry wall. The collection trench was chosen as it could be installed lower in elevation than the planned final grade of the landfill, on the edge of the current solid waste, and in the fractured rock (which is believed to be the primary conduit for contaminated groundwater). Moreover, a collection trench would be more cost effective than multiple pumping wells. As the landfill material level rises, the collection trench will be covered and is expected to continue to collect of groundwater flowing horizontally from the landfill as well as vertically from the material above the trench. Optimally, a pumping trench is installed downgradient of the contamination source spanning the entire width and depth of the source. In this case, the solid waste is too massive for these dimensions to be feasible. The pumping trench at the research area cannot feasibly be installed around the entire landfill or through all relevant aquifers. Therefore, this trench is designed to limit flow through the saddle only. Further, due to equipment limitations, the collection trench is not as deep as the coal seams. When the final design of the collection trench and slurry wall was finished there was concern that the collection trench was too far from the slurry wall, so to add redundancy and to remove water from the coal seam a single pumping well was added to the trench system.

The three groundwater control devices were installed at the study area to prevent contaminated groundwater from flowing through the saddle in the ridge and toward Spring-2 (Figure 4 and 5). Directly down gradient of the landfill an interceptor trench was installed. A pumping well was installed down gradient of the landfill, and directly up gradient of the slurry wall. A slurry wall was installed in the topographic low area of the ridge between the solid waste landfill and Spring-2. The pumping trench primarily controls groundwater flow through the fractured bedrock, and relies on the pumping well to control groundwater flow through the sandstone and coal seams. 


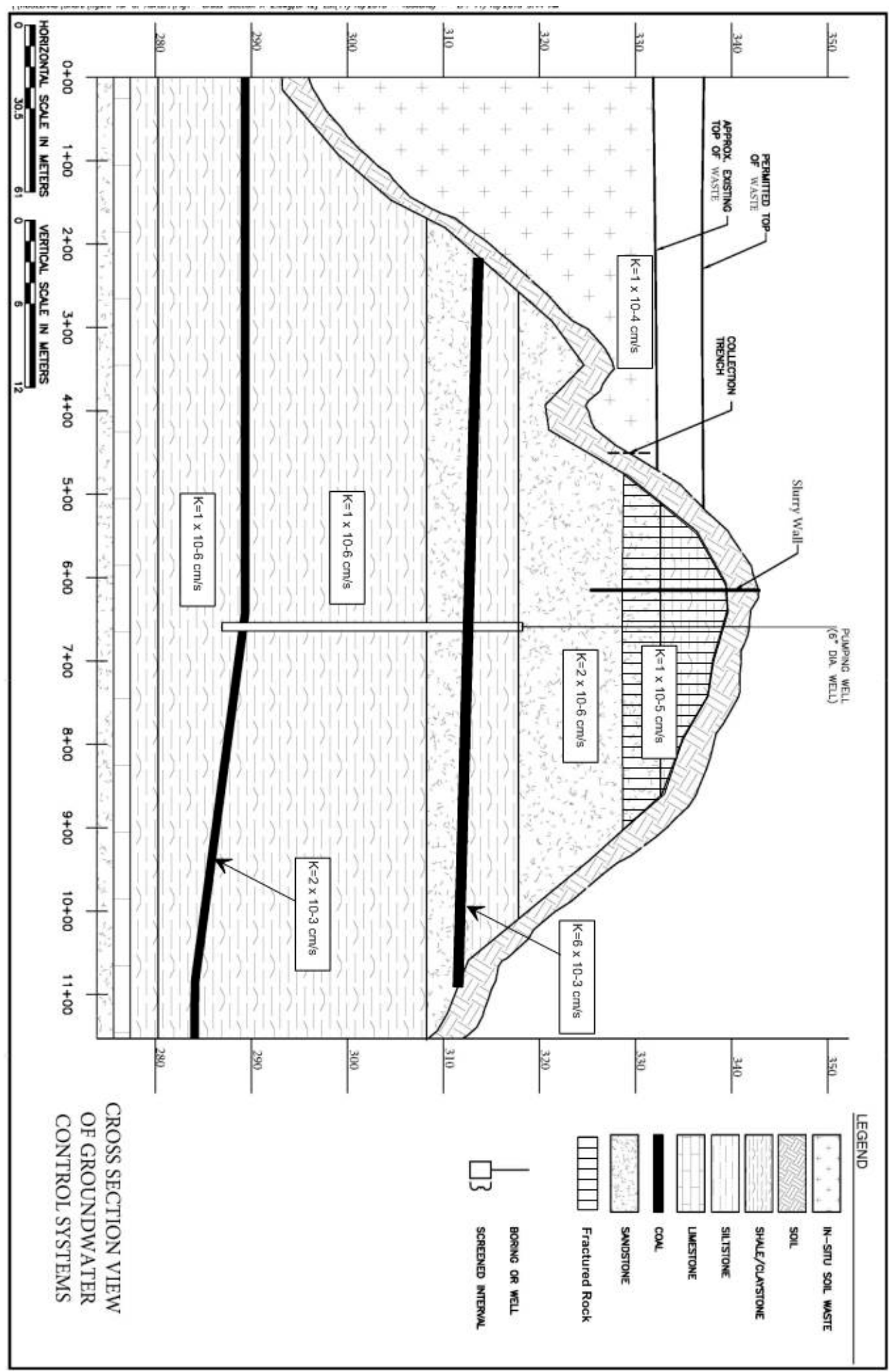

Figure 5. Cross Section A of Research Area

Cross section view of study area showing the solid waste limit, the elevation solid waste will end up at, locations of the pumping trench, slurry wall, and pumping well and the rock units each intercepts. 
Water quality at Spring-1 and Spring-2 was similar in 2010 and 2011 (Figure 6). Spring-2 is directly down gradient of the three groundwater control devices and outcrops at the Brush Creek coal seam. The groundwater that feeds Spring- 2 is believed to flow from the landfill and through the saddle in the ridge. Water quality samples were collected monthly to measure contaminant concentrations in Spring-2. Contaminant concentrations in Spring-2 are used to indicate if the three groundwater control devices effectively prevent contaminated groundwater from flowing through the saddle off site as water levels rise in the landfill. 

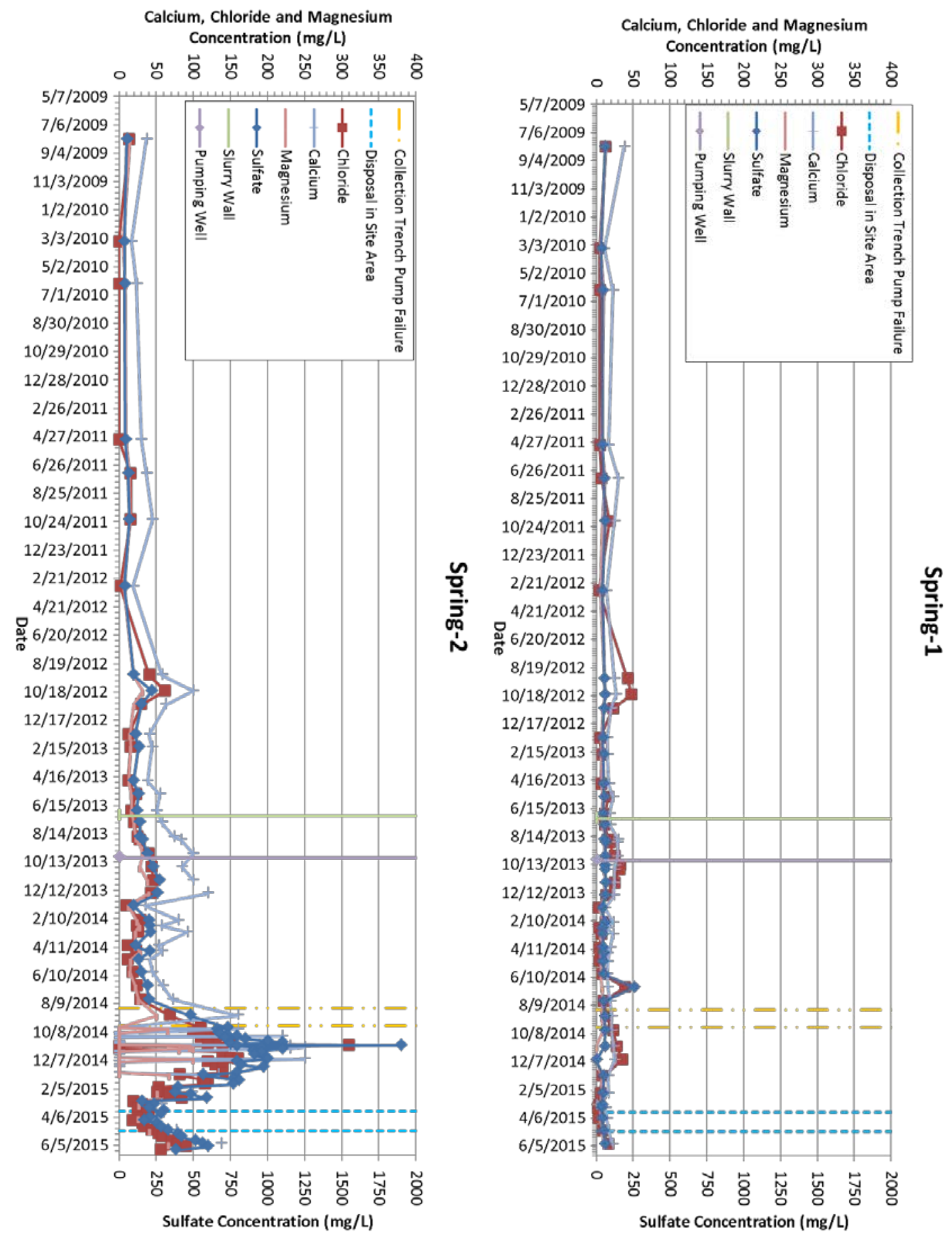

Figure 6. Water Quality at Spring-1 and Spring-2

Water quality at Spring-1 and Spring-2 over time showing similar water quality in 2010 and 2011. 


\subsubsection{Local Geology}

\subsubsection{Geography \& Climate}

The Site lies within the Allegheny Plateau physiographic province (Van, 1951) of western Pennsylvania. The mean annual air temperature is $11^{\circ} \mathrm{C}$ with an average annual precipitation of 97 centimeters (Van, 1951).

\subsubsection{Geology}

The Allegheny Plateau physiographic province is characterized by gently dipping coal measures of complex stratigraphy. No major fold or faults are present in the area. The upper stratigraphic unit on site is the Glenshaw formation (Figure 7).

The lower Mahoning sandstone is the lowest formation considered for this research. This unit is comprised of fine to medium fine-grained micaceous quartz sandstone. The lower Mahoning sandstone has numerous fractures. The lower Mahoning sandstone is overlaid by an unnamed shale unit. The Mahoning Coal overlies the unnamed shale unit. The upper Mahoning overlays the Mahoning coal seam. It is comprised of very fine-grained, gray, silty, micaceous sandstone. This unit directly overlies the Mahoning coal and is overlain by the Brush Creek coal. The Brush Creek coal seam is an important aquifer system at this Site. The Brush Creek coal is generally 35 to 71 centimeters (cm) thick, ranked as high-volatile A bituminous (Petterson, 1963). The Brush Creek coal has a high heat value with a moisture content ranging from 1.8 to 6.8 percent, volatile matter from 30.2 to 41.1 percent, an average sulfur content of 2.8 percent, and average ash content of 9.4 percent (Petterson, 1963). According to the County Coal Resources report, the Brush Creek coal primarily crops out near the tops of hills but is generally thin and discontinuous. The Brush Creek coal is not economically minable in the vicinity of the Site. Alternating units of unnamed shale and sandstone overlie the Brush Creek Coal. The sandstones are calcareous sandstones and/or contain limestone lenses.

Surficial residuum ranges up to $7.3 \mathrm{~m}$ in thickness and consists of residual clay, silt, sand, and weathered rock. 


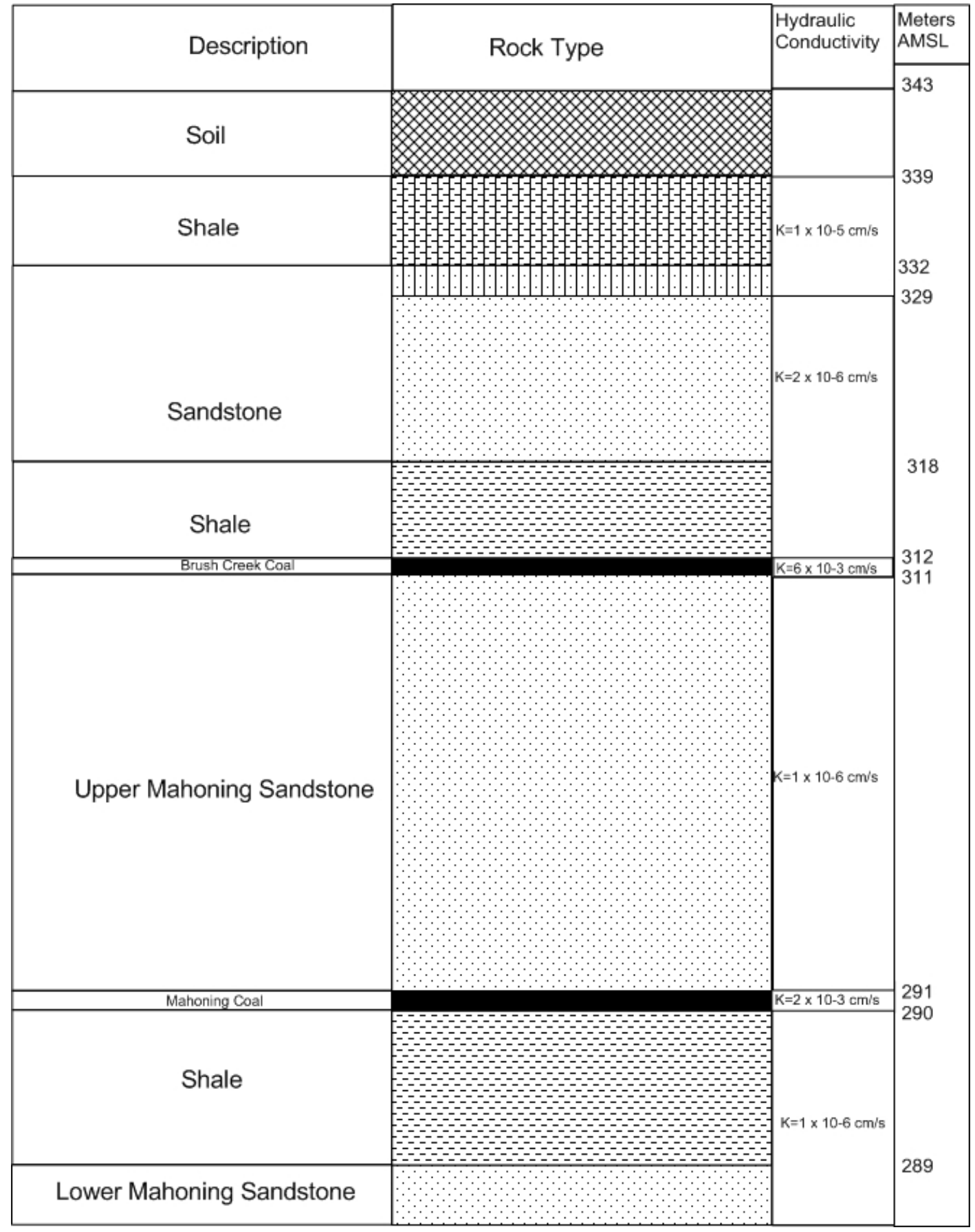

\section{Figure 7. Stratigraphic Section}

Generalized stratigraphic section of the Glenshaw Formation. Hydraulic conductivities correspond to those determined in section 3.1

\subsubsection{Groundwater}

The stratigraphic units present at the Site vary in permeability. The permeable strata, generally sandstones and coals, act as aquifers and transmit groundwater. The less permeable strata, such as shales, siltstones, claystones, and underclays are aquitards which restrict flow. The 
Middle Glenshaw aquifer, the shallowest bedrock aquifer at the Site, is located in the Brush Creek coal, upper Mahoning sandstone, and the Mahoning coal. The aquifer is located in multiple rock formations due to the similar hydraulic conductivities. These strata crop out on the ridge at elevations between 290 and 312 m AMSL. The Middle Glenshaw Aquifer is separated from the lower aquifers by confining siltstones, shales and claystones.

\subsubsection{Background Water Quality}

Background water quality for the Site and surrounding county was synthesized from multiple sources. The County Groundwater Resources Report includes analysis of water from 26 wells across the county (Patterson, 1963). These samples were a collected primarily by water companies (Table 1). The water collected during the reporting period in 1946 is relatively neutral, with low levels of metals and a moderately high level of total dissolved solids (TDS).

The second source of background water quality for the area, sampled mine drainage from the Brush Creek coal in 1995 (Hornberger, 2004, shown in Table 1). The limited parameters collected show constituent composition is similar if not lower than the average water quality collected for the entire county. The water is neutral with low levels of metals and a low total suspended solid (TSS).

The third source of background water quality is from a spring on the study site (Spring-1) which is not believed to be impacted by the solid waste. Water quality samples have been collected from this location on a regular basis starting on March 11, 2010 (Table 1). Parameters like pH, iron, manganese, and bicarbonate are similar to average county wide groundwater quality background water quality sources. The water quality at Spring-1 for calcium, magnesium, sulfate, chloride, nitrate, TDS, and alkalinity are lower than the other background water measurements. 
Table 1. Water Quality Comparison

Water quality comparison between the 26 samples from the Groundwater Resources Report (Patterson, 1963), mine drainage from the Brush Creek Coal (Hornberger 2004), and the two springs in the study area.

\begin{tabular}{|c|c|c|c|c|c|c|}
\hline Location & \multicolumn{3}{|c|}{1946 County Quality } & \multirow{2}{*}{$\begin{array}{c}\begin{array}{c}\text { Mine } \\
\text { Drainage }\end{array} \\
7 / 12 / 1995 \\
\end{array}$} & \multirow{2}{*}{$\begin{array}{c}\text { Spring-1 } \\
3 / 11 / 2010 \\
\end{array}$} & \multirow{2}{*}{$\begin{array}{c}\text { Spring-2 } \\
3 / 11 / 2010 \\
\end{array}$} \\
\hline & minimum & average & maximum & & & \\
\hline Parameter & & & & & & \\
\hline pH (S.U.) & 6.1 & 7.2 & 7.8 & 6.9 & 6.31 & 6.43 \\
\hline Silica (mg/L) & 6.0 & 10.0 & 14.0 & & & \\
\hline Manganese (mg/L) & 0.0 & 0.3 & 1.6 & 0.4 & 0.55 & 6 \\
\hline Iron (mg/L) & 0.0 & 0.5 & 5.0 & 0.21 & 0.75 & 0.1 \\
\hline Calcium (mg/L) & 24.0 & 81.0 & 175.0 & & 11 & 17 \\
\hline Magnesium (mg/L) & 7.0 & 22.0 & 78.0 & & 5.9 & 6 \\
\hline Bicarbonate (mg/L) & 63.0 & 83.0 & 96.0 & & 6.8 & 21 \\
\hline Sulfate $(\mathrm{mg} / \mathrm{L})$ & 25.0 & 108.0 & 325.0 & 68 & 35 & 36 \\
\hline Chloride (mg/L) & 14.0 & 35.0 & 103.0 & & 5 & 0 \\
\hline Nitrate(mg/L) & 3.5 & 5.4 & 8.0 & & 2.3 & 1.8 \\
\hline TDS (mg/L) & 260.0 & 478.0 & 670.0 & & 80 & 96 \\
\hline $\begin{array}{c}\text { Total Hardness } \\
\text { (mg/L) }\end{array}$ & 93.0 & 260.0 & 528.0 & & & \\
\hline Alkalinity (mg/L) & 98.0 & 178.0 & 253.0 & 189 & 6.8 & 21 \\
\hline Acidity (mg/L) & 0.0 & 8.4 & 20.0 & & & \\
\hline Aluminum (mg/L) & & & & 0.07 & & \\
\hline TSS (mg/L) & & & & 1 & & \\
\hline
\end{tabular}

The fourth source of background water quality is Spring-2 which, though later affected by changes in groundwater quality caused by the landfill, is considered "background" water quality from August 2009 through September 2012 when the groundwater elevation in the landfill was below the fractured bedrock. The sample from March 11, 2010 was used to represent pre-impact water quality at Spring-2 and evaluate water quality changes followed subsequent disposal of solid waste. The entire water quality record for Spring-2 is shown in Appendix A and pre-impact data included in Table 1. Parameters like $\mathrm{pH}$, iron, and bicarbonate are similar to other background water quality sources. Similar to Spring-1, the Spring-2 calcium, magnesium, sulfate, chloride, 
nitrate, TDS and alkalinity concentrations are lower than those reported in the other background water quality data. However, pre-impact manganese levels at Spring-2 are higher than the other background water chemistry samples.

Table 2. Site Water Quality Compared to Background Spring-1 and Spring-2 10/16/2012 data compared to background water quality

\begin{tabular}{|c|c|c|c|c|c|c|c|}
\hline \multirow[t]{2}{*}{ Location } & \multicolumn{2}{|c|}{ Spring-2 } & \multicolumn{2}{|c|}{ Spring-1 } & \multirow[t]{2}{*}{$\begin{array}{c}1946 \\
\text { County } \\
\text { quality }\end{array}$} & \multirow[t]{2}{*}{$\begin{array}{c}\text { Mine } \\
\text { Drainage }\end{array}$} & \multirow[t]{2}{*}{$\begin{array}{c}\text { Landfill } \\
\text { water }\end{array}$} \\
\hline & $3 / 11 / 2010$ & $10 / 16 / 2012$ & $3 / 11 / 2010$ & $10 / 16 / 2012$ & & & \\
\hline Parameter & $\begin{array}{c}\text { pre- } \\
\text { impact }\end{array}$ & & $\begin{array}{c}\text { pre- } \\
\text { impact }\end{array}$ & & & & \\
\hline pH (S.U.) & 6.43 & 6.72 & 6.31 & 6.95 & 7.2 & 6.9 & 7.25 \\
\hline Silica (mg/l) & & & & & 10 & & \\
\hline Manganese (mg/l) & $<0.005$ & 0.36 & 0.55 & 0.17 & 0.28 & 0.4 & 0.001 \\
\hline Iron (mg/l) & 0.1 & 0.83 & 0.75 & 0.09 & 0.47 & 0.21 & 0.018 \\
\hline Calcium (mg/l) & 17 & 100 & 11 & 27 & 81 & & 480 \\
\hline Magnesium (mg/l) & 6 & 32 & 5.9 & 12 & 22 & & 86 \\
\hline Bicarbonate (mg/l) & 21 & 170 & 6.8 & 33 & 83 & & 150 \\
\hline Sulfate (mg/l) & 36 & 220 & 35 & 59 & 108 & 68 & 2400 \\
\hline Chloride (mg/l) & 0 & 62 & 5 & 48 & 35 & & 370 \\
\hline Nitrate (mg/l) & 1.8 & 0.12 & 2.3 & 0.05 & 5.4 & & 1.4 \\
\hline TDS (mg/l) & 96 & 490 & 80 & 210 & 478 & & 4400 \\
\hline Hardness (mg/l) & & & & & 260 & & \\
\hline Alkalinity (mg/l) & 21 & 170 & 6.8 & 33 & 178 & 189 & 150 \\
\hline Acidity & & & & & 8.4 & & \\
\hline Aluminum (mg/l) & & & & & & 0.07 & 0.0033 \\
\hline TSS (mg/l) & & & & & & 1 & \\
\hline
\end{tabular}

\subsection{WATER QUALITY IMPACTS}

During the October 16, 2012 sampling event, high levels of chloride, calcium, sulfate, and magnesium were detected in Spring-2 (Figure 6) compared to background water quality (Table 2). This was believed to be caused by the high groundwater levels in the landfill creating sufficient 
head to push groundwater through the Brush Creek Coal seam and fractured upper bedrock zone and therefore across the groundwater divide. Calcium increased from $17 \mathrm{mg} / \mathrm{L}$ to $100 \mathrm{mg} / \mathrm{L}$, chloride increased from $16 \mathrm{mg} / \mathrm{L}$ to $62 \mathrm{mg} / \mathrm{L}$, magnesium increased from $6 \mathrm{mg} / \mathrm{L}$ to $32 \mathrm{mg} / \mathrm{L}$, and sulfate increased from $36 \mathrm{mg} / \mathrm{L}$ to $220 \mathrm{mg} / \mathrm{L}$. In addition to these increases, TDS increased from $96 \mathrm{mg} / \mathrm{L}$ to $490 \mathrm{mg} / \mathrm{L}$ and alkalinity increased from $21 \mathrm{mg} / \mathrm{L}$ to $170 \mathrm{mg} / \mathrm{L}$. The increase is clearly larger than the small increase observed at Spring-1 as the October 16, 2012 sample from Spring-1 had only slightly elevated levels of calcium, chloride, magnesium and sulfate. The impacts to Spring-2 during this sampling event suggested that contaminated groundwater was flowing through the ridge, and because additional solid waste was going to be placed in this area it was believed that concentrations of calcium, magnesium, chloride and sulfate would increase. It was decided that a groundwater control system was required to reduce, if not prevent, contaminated groundwater from flowing through the ridge to downstream receptors.

\subsection{AQUIFER PROPERTIES}

\subsubsection{Hydraulic Properties}

Rising head and falling head single well hydraulic conductivity tests (slug tests), single well and multi-well pumping tests were conducted in bedrock and in the waste material to calculate the hydraulic conductivity, transmissivity, specific yield and storativity of the rock units on Site. Tests conducted in the fractured bedrock were assumed to be under unconfined conditions, and tests conducted in the Brush Creek coal seam and below were assumed to be under confined conditions.

In development of the conceptual model for the site, the stratigraphic units were considered based on their hydraulic properties as determined by single-well permeability testing results, pump test results and lithology. Lithologic units with similar hydraulic permeabilities were grouped together as hydrostratigraphic units.

Evaluations of all hydraulic property tests were conducted using Aqtesolv Pro (Version 4.0; Duffy, 2015). Inputs into the system include, well construction information water height in well, displacement observed, and the water levels collected during the test. 


\subsubsection{Piezometer Installation}

\subsubsection{Solid Waste Piezometers}

Piezometers were installed in the solid waste landfill to collect groundwater elevations data, perform slug tests, and to perform pumping tests.

Each piezometer boring was advanced by $16 \mathrm{~cm}$ diameter hollow stem augers (HSA) through the entire the solid waste. The pumping well, 12-10, was advanced to $37 \mathrm{~m}$ deep. The observation piezometers, 12-10A and 12-10B, were advanced $6 \mathrm{~m}$ deep each. The piezometer used as the pumping well for the study, 12-10 was constructed of $5 \mathrm{~cm}$ diameter PVC with $0.025 \mathrm{~cm}$ slot screened across the entire water table (7-37 m below ground surface (bgs)). The observation piezometers, 12-10A and 12-10B, were constructed with $5 \mathrm{~cm}$ diameter PVC casing and $3 \mathrm{~m}$ of $0.025 \mathrm{~cm}$ slot screen. The annulus around the screen was filled with clean quartz sand and capped with a hydrated bentonite seal. The remaining annulus was filled to the ground surface with hydrated bentonite chips. The piezometers were completed with a steel protective cover and 0.75 m diameter concrete pad. Well construction details are shown on Table 3 and the boring logs are attached as Appendix B. 
Table 3. Piezometer Construction Details

Piezometer construction details for the monitoring wells and piezometers

were installed for the study.

\begin{tabular}{|c|c|c|c|c|c|c|c|c|c|c|c|}
\hline \multirow{4}{*}{$\frac{\text { Well }}{\text { MW-101 }}$} & \multirow{4}{*}{$\begin{array}{c}\text { Depth } \\
m \\
14.54\end{array}$} & \multicolumn{2}{|c|}{ Elevation } & \multicolumn{6}{|c|}{ Screen Interval } & \multirow{4}{*}{$\frac{\text { Location }}{\text { Ridgeline }}$} & \multirow{4}{*}{$\begin{array}{c}\text { Completion Zone } \\
\text { First water, undesignated }\end{array}$} \\
\hline & & Ground & Casing & \multirow{2}{*}{\multicolumn{3}{|c|}{$\begin{array}{c}\text { Depth } \\
m\end{array}$}} & \multirow{2}{*}{\multicolumn{3}{|c|}{$\begin{array}{c}\text { Elevation } \\
m M S L \\
\end{array}$}} & & \\
\hline & & \multirow{2}{*}{$\frac{m M S L}{343.83}$} & \multirow{2}{*}{$\frac{m M S L}{344.59}$} & & & & & & & & \\
\hline & & & & 14.54 & - & 11.52 & 329.29 & 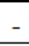 & 332.31 & & \\
\hline MW-102 & 14.08 & & 345.70 & 14.11 & - & 11.06 & 330.98 & - & 334.03 & Ridgeline & First water, undesignated \\
\hline MW-103A & 11.58 & 343.47 & 344.19 & 11.58 & - & 8.53 & 331.89 & - & 334.94 & Ridgeline & First water, undesignated \\
\hline MW-103C & 43.37 & 343.52 & 344.28 & 43.37 & - & 40.33 & 300.15 & - & 303.20 & Ridgeline & Lower Glenshaw aquifer \\
\hline MW-104 & 7.62 & & 340.54 & 7.62 & - & 4.57 & 332.31 & - & 335.36 & Ridgeline & First water, undesignated \\
\hline MW-105 & 10.06 & 344.58 & 345.34 & 10.06 & - & 7.01 & 334.52 & - & 337.57 & Ridgeline & First water, undesignated \\
\hline MW-106 & 8.53 & & 352.65 & 8.53 & - & 5.49 & 343.50 & - & 346.55 & Ridgeline & First water, undesignated \\
\hline MW-107A & 12.19 & 351.02 & 351.78 & 12.19 & - & 9.14 & 338.83 & - & 341.88 & Ridgeline & First water, undesignated \\
\hline MW-107B & 39.90 & 351.06 & 351.82 & 39.90 & - & 36.85 & 311.16 & - & 314.21 & Ridgeline & Mahoning coal \\
\hline MW-107C & 44.90 & 350.95 & 351.71 & 44.90 & - & 41.85 & 306.06 & - & 309.10 & Ridgeline & Glenshaw Formation \\
\hline MW-108 & 11.64 & & 353.27 & 11.64 & - & 8.60 & 341.02 & - & 344.07 & Ridgeline & First water, undesignated \\
\hline MW-110 & 17.56 & & 343.36 & 17.56 & - & 14.51 & 325.19 & - & 328.24 & Ridgeline & First water, undesignated \\
\hline MW-111 & 7.01 & 354.02 & 354.78 & 7.01 & - & 3.96 & 347.01 & - & 350.05 & Ridgeline & First water, undesignated \\
\hline OW-112B & 15.54 & 342.76 & 343.45 & 12.50 & - & 15.54 & 330.27 & - & 327.22 & Ridgeline & Brush Creek coal \\
\hline $\mathrm{P}-1(220)$ & 67.06 & 333.79 & 334.40 & 67.06 & - & 0.00 & 266.73 & - & 333.79 & Landfill & Solid Waste \\
\hline P-1(150) & 45.72 & 333.82 & 334.26 & 45.72 & - & 42.67 & 288.10 & - & 291.14 & Landfill & Solid Waste \\
\hline $\mathrm{P}-1(50)$ & 15.24 & 333.79 & 334.48 & 15.24 & - & 12.19 & 318.55 & - & 321.60 & Landfill & Solid Waste \\
\hline $12-10 \mathrm{~A}$ & 6.10 & 338.27 & 338.90 & 6.10 & - & 1.52 & 332.18 & - & 336.75 & Landfill & Solid Waste \\
\hline
\end{tabular}

\subsubsection{Bedrock Piezometers}

Piezometers were installed and screened at varying depths in bedrock to collect groundwater elevation data, perform slug tests, and to perform pumping tests.

Each piezometer boring was advanced by $16 \mathrm{~cm}$ diameter HSA to bedrock refusal. Once the piezometer borings could no longer be advanced using HSA, air rotary or "HQ" (6.3 cm diameter) coring was used to advance the borehole to the desired depth. The piezometers were constructed with $5 \mathrm{~cm}$ diameter PVC casing and 3 meters of $0.025 \mathrm{~cm}$ slot screen. Table 3 shows where each piezometer was installed (by specific rock formation, or when groundwater was first encountered). The annulus around the screen was filled with clean quartz sand and capped with a hydrated bentonite seal. The remaining annulus was filled to the ground surface with hydrated bentonite chips. The piezometers were completed with a steel protective cover and $0.75 \mathrm{~m}$ diameter concrete pad. 


\subsubsection{Slug Tests}

\subsubsection{Solid Waste}

Slug tests were conducted on four piezometers completed in the solid waste material to estimate in-situ hydraulic conductivities. Tests were evaluated using either the Bower-Rice or Cooper-Bredehoeft-Papadopulos method, depending on the trend of the recovery data. The best fit lines for multiple methods like the Bower-Rice, Copper-Bredehoeft-Papadopulos, Hvorslev, and KGS models were used to determine which method fit the best. Once the best method was determined the best fit line was adjusted to match data patterns. For example, Figure 8 shows a Bouwer-Rice solution. However, the best fit line takes all of the data into account and the fit line does not match with the data curve. To improve the fit, a line is chosen based on one of the three sections of data: 1) the early data (first 75 seconds on Figure 8). This section of data is generally considered to reflect drainage of the filter pack. Therefore, the early data are usually not included in the best fit line. 2) The second data section (75 second to 480 second range on Figure 8). These data are usually the section used for the best fit line due to the size of the differential head (water level change between the formation and the water level in the well) and the resulting maximum in flow. 3) The third data section (>480 second on Figure 8 ) is usually the longest section. The hydraulic conductivity changes from $8.5 \times 10^{-4} \mathrm{~cm} / \mathrm{sec}$ (the initial best fit for all of the data) to 3.5 $\mathrm{x} 10^{-4} \mathrm{~cm} / \mathrm{sec}$ when the best fit line is adjusted to the most appropriate data. 

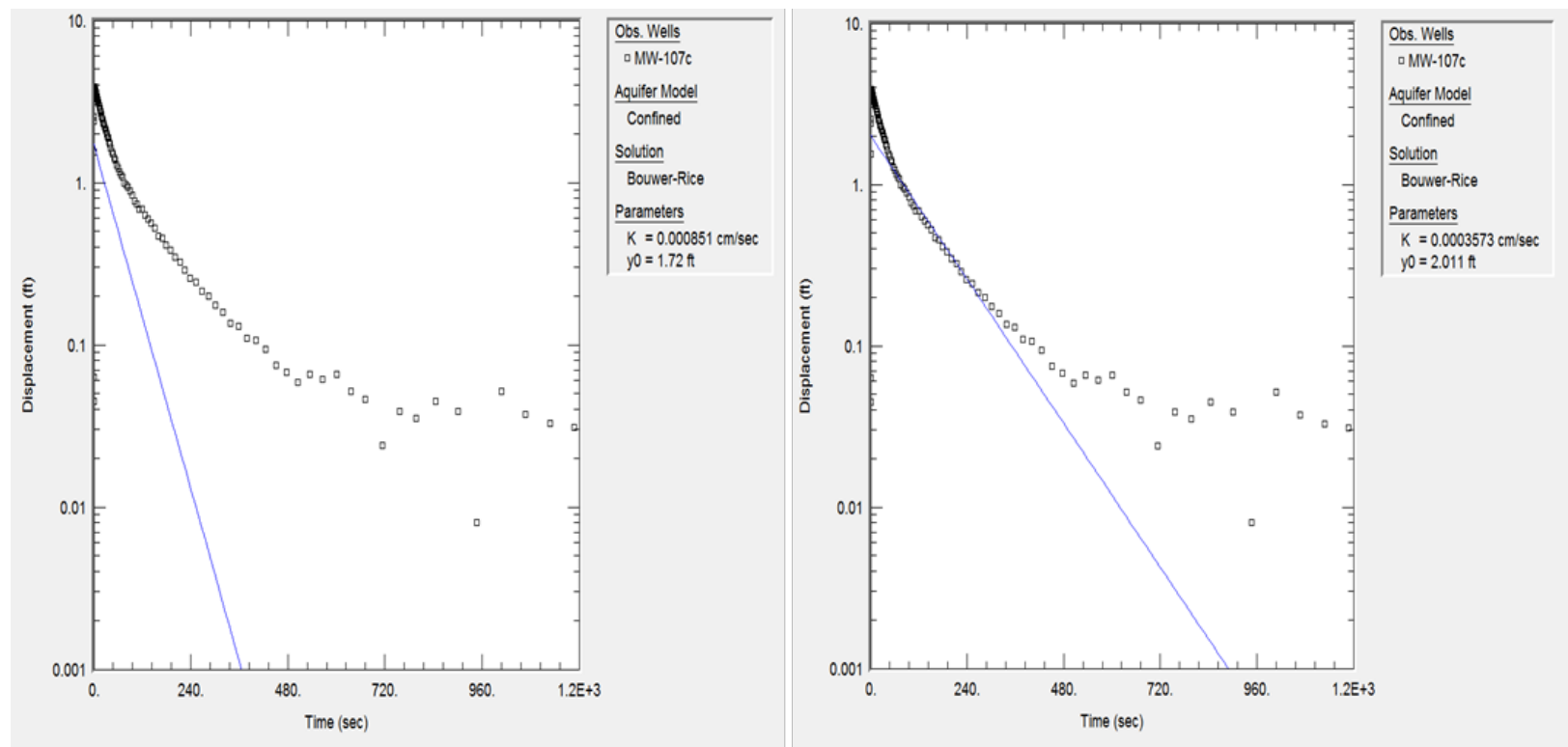

Figure 8. Hydraulic Conductivity Determination

Uncorrected slug test data from monitoring well MW-107 on the left and the same data on the right after visual compensation

\subsubsection{Bedrock}

Slug tests were conducted on 12 wells located along the ridge of the site to estimate hydraulic conductivities. Tests were primarily analyzed using the Bower-Rice method for unconfined aquifers with the exception of piezometer MW-107C which was analyzed using the KGS model. Most of these piezometers targeted the uppermost occurrence of groundwater, without regard for geologic stratum. Exceptions were MW-107B, which was completed in the Mahoning coal, and MW-107C, which was completed in a lower portion of the Glenshaw Formation.

\subsubsection{Single Well Pumping Test}

A single well pumping test was conducted at piezometer MW-103B to assess the properties of the Mahoning coal seam along the ridge.

The test was initiated on November 2, 2012 and lasted 90 minutes. After pumping stopped the recovery was measured and test data was evaluated using the This recovery solution for a confined aquifer. 


\subsubsection{Multi-Well Pumping Test}

\subsubsection{Solid Waste}

A pumping test was conducted at piezometer 12-10 to assess the in-situ aquifer properties of the solid waste material. Observation wells for the tests were piezometers 12-10A, located 3.9 $\mathrm{m}$ from the pumping well, and 12-10B, located $8 \mathrm{~m}$ from the pumping well. All piezometers were equipped with transducers and data loggers to record drawdowns.

The test was initiated on October 3, 2012 at 8:31 AM, and continued for 52 hours. The pumping rate was maintained between 26.4 and 29.1 liters per minute (lpm) for most of the test, after ramping up from an initial $21.9 \mathrm{lpm}$. Drawdowns at the end of the test appeared to have reached steady state. Test data was evaluated for wells 12-10A and 12-10B using the Cooper-Jacob solution for an unconfined aquifer. 


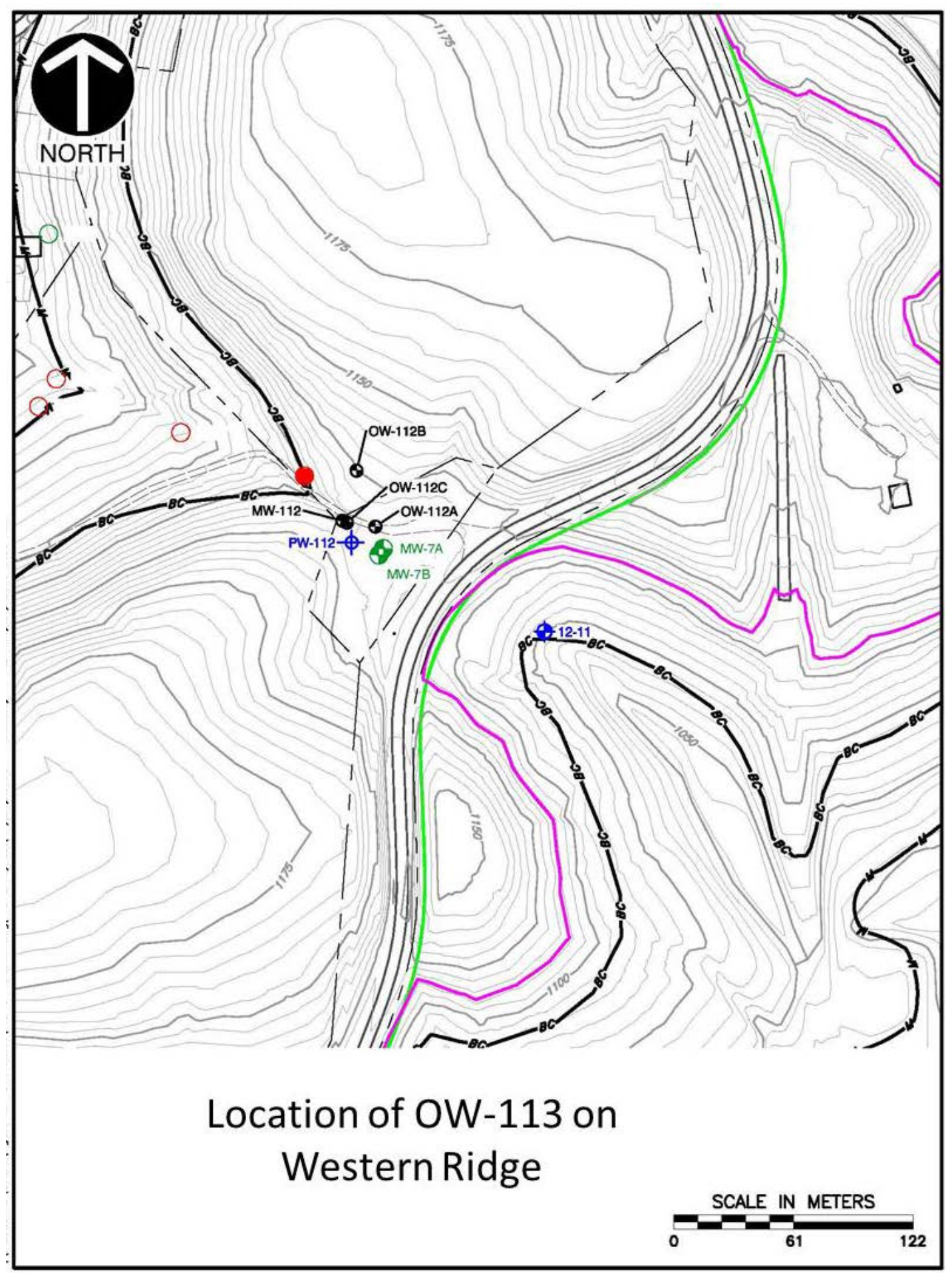

Figure 9. Location Map of OW-112b

The location on the West side of the solid waste landfill where the slug test of the Brush Creek Coal was conducted at $\mathrm{OW}-112 b$. 


\subsubsection{Bedrock}

A pumping test was conducted at piezometer MW-103B to assess the properties of the rock units along the ridge. Observations wells for the test were piezometers MW-102B located $52 \mathrm{~m}$, MW-105B located 135 m, MW-107B located 548 m, and MW-116B located $122 \mathrm{~m}$ from the pumping well. All piezometers were equipped with transducers and data loggers to record drawdowns.

The test was initiated on December 5, 2012 and continued for 47 hours. The pumping rate was maintained at $28.4 \mathrm{lpm}$. This test specifically targeted the Mahoning coal, to test whether this stratum was carrying a disproportionate amount of the groundwater beneath the ridge. The coal is approximately $1.5 \mathrm{~m}$ thick in this area.

An additional pumping test was conducted at piezometer MW-112 on the opposite side of the solid waste landfill from the study area (Figure 9). This pumping test had an observation piezometer, OW-112B which was screened across the Brush Creek coal seam. The test was initiated on October 8, 2012 and continued for 44 hours. The pumping rate was maintained at $5.7 \mathrm{lpm}$. This test was screened across multiple formations, but observation piezometer OW-112B was screened in the Brush Creek coal seam.

\subsection{GROUNDWATER CONTROL INSTALLATIONS}

\subsubsection{Slurry Wall}

Approximately 215 linear meters of soil-bentonite slurry wall was installed on the ridge (Figure 4 and 5). The wall was installed to elevation $332 \mathrm{~m}$ AMSL, approximately $12 \mathrm{~m}$ below ground surface at the crest of the topographic saddle near MW-103. The wall was installed between June 6, 2013 and July 7, 2013. Hydraulic conductivity testing on the trial mixes was performed to determine conformance with the specified permeability of $10^{-7} \mathrm{~cm} / \mathrm{sec}$. Laboratory testing of samples was performed to confirm the hydraulic conductivity of the placed material. The hydraulic conductivity ranged from $2.2 \times 10^{-8}$ to $7.6 \times 10^{-8} \mathrm{~cm} / \mathrm{sec}$. 


\subsubsection{Collection Trench}

Approximately 426 linear meters of groundwater collection trench was installed $15 \mathrm{~m}$ from the solid waste $3 \mathrm{~m}$ deep (Figure 4 and 5). The collection trench was installed between June 3 and June 19, 2013. The drain includes three HDPE slope riser pipes and pumps to remove collected water. The pumps installed in the slope risers are EPG 17-2 Sump Drainer pumps with level sensors that are controlled by individual EPG Pumpmaster Controllers. The slope risers are fitted with disconnects to allow for removal and servicing of the pumps. The pumps discharge to the treatment system via individual $7.6 \mathrm{~cm}$ HDPE force mains. Pumping in the slope risers commenced on June 26, 2013 in the middle slope riser utilizing a temporary pump. Final pump installation occurred on September 4, 2013. A failure of the pumping trench occurred August 18 to October 6, 2014 and is discussed in section 3.2 .

\subsubsection{Pumping Well}

Pumping well PW-103 was installed after completion of the barrier wall and collection trench (Figure 4).

The boring was advanced by $16 \mathrm{~cm}$ diameter HSA to bedrock refusal. Once the borings could no longer be advanced using HSA, air rotary was used to advance the borehole to the Mahoning Coal seam. The well was constructed with $10 \mathrm{~cm}$ diameter PVC casing and $0.025 \mathrm{~cm}$ slot screen. The annulus around the screen was filled with clean quartz sand and capped with a hydrated bentonite seal. The remaining annulus was filled to the ground surface with hydrated bentonite chips. The piezometers were completed with a steel protective cover and $0.75 \mathrm{~m}$ diameter concrete pad.

The pumping well is screened across the Brush Creek and Mahoning Coal seams to intercept any constituents which migrate through the permeable units (Figure 5). The pumping well screen was constructed from approximate elevation 325 to 300 m AMSL. A Grundfos Rediflo3 SQE-NE submersible pump was installed in the well. The flow from the well is estimated to be less than $38 \mathrm{lpm}$ and discharges to the treatment plant via $7.6 \mathrm{~cm}$ HDPE pipe. The pumping rate 
and water level is controlled with a Grundfos CU 300 control unit with a submersible pressure transducer. 


\subsection{RESULTS}

\subsection{AQUIFER PROPERTIES}

\subsubsection{Slug Tests}

\subsubsection{Solid Waste}

The wells completed to intersect the top of the water table exhibit a range of hydraulic conductivity from $7 \times 10^{-7}$ to $4 \times 10^{-5} \mathrm{~cm} / \mathrm{sec}$, with a median of $1 \times 10^{-5} \mathrm{~cm} / \mathrm{sec}$. The results of the slug test analyses shown on Table 4. Complete Aqtesolv spreadsheets are attached in Appendix C.

\subsubsection{Bedrock}

The wells completed at first water exhibit a range of hydraulic conductivity from $7 \times 10^{-7}$ to $4 \times 10^{-5} \mathrm{~cm} / \mathrm{sec}$, with a median of $1 \times 10^{-5} \mathrm{~cm} / \mathrm{sec}$. The results of the slug test analyses are shown on Table 4 and depicted on Figures 10 and 11. Complete Aqtesolv spreadsheets are attached in Appendix C. 
Table 4. Slug Test Results

Slug test results, the solution used for each analysis and how well the curve matched the data.

\begin{tabular}{|c|c|c|c|c|c|}
\hline & & & $\begin{array}{c}\text { Hydraulic } \\
\text { Conductivity }\end{array}$ & Solution & $\begin{array}{l}\text { Match } \\
\text { Quality }\end{array}$ \\
\hline Well & Location & Completion Zone & $\mathrm{cm} / \mathrm{sec}$ & & \\
\hline $12-10 \mathrm{~A}$ & Landfill & Solid Waste & 4.E-05 & Bouwer-Rice & Very good \\
\hline P-1(50) & Landfill & Solid Waste & 9.E-07 & $\begin{array}{c}\text { Cooper-Brdehoeft- } \\
\text { Papadopulos }\end{array}$ & Fair/poor \\
\hline P-1(150) & Landfill & Solid Waste & 1.E-06 & $\begin{array}{c}\text { Cooper-Brdehoeft- } \\
\text { Papadopulos }\end{array}$ & Fair/poor \\
\hline $\mathrm{P}-1(220)$ & Landfill & Solid Waste & 1.E-03 & Bouwer-Rice & Very good \\
\hline MW-101 & Ridgeline & First water, undesignated & 2.E-06 & Bouwer-Rice & Very good \\
\hline MW-103A & Ridgeline & First water, undesignated & 3.E-06 & Bouwer-Rice & Fair \\
\hline MW-103C & Ridgeline & Lower Glenshaw aquifer & 2.E-06 & Bouwer-Rice & Very good \\
\hline MW-105 & Ridgeline & First water, undesignated & 1.E-05 & Bouwer-Rice & Good \\
\hline MW-107A & Ridgeline & First water, undesignated & 2.E-06 & Bouwer-Rice & Good \\
\hline MW-107B & Ridgeline & Mahoning coal & 9.E-05 & Bouwer-Rice & Very good \\
\hline MW-107C & Ridgeline & Glenshaw Formation & 9.E-04 & KGS Model & Fair \\
\hline MW-110 & Ridgeline & First water, undesignated & 7.E-07 & Bouwer-Rice & Good \\
\hline MW-111 & Ridgeline & First water, undesignated & 2.E-05 & Bouwer-Rice & Fair \\
\hline MW-113 & Ridgeline & & 2.E-05 & Bouwer-Rice & Fair/poor \\
\hline MW-114A & Ridgeline & & 2.E-05 & Bouwer-Rice & Good \\
\hline MW-114B & Ridgeline & & 3.E-04 & Bouwer-Rice & Fair \\
\hline
\end{tabular}

\subsubsection{Single Well Pumping Test}

The transmissivity obtained from the single well pumping test was $0.57 \mathrm{~cm}^{2} / \mathrm{sec}$ (Table 5 , Figure 10 and 11) which is in reasonable agreement with the multi-well pumping test transmissivity of $0.3 \mathrm{~cm}^{2} / \mathrm{sec}$ at MW-103B and the transmissivity of $0.2884 \mathrm{~cm}^{2} / \mathrm{sec}$ at $\mathrm{MW}-112$ discussed below.

\subsubsection{Multi-Well Pumping Test}

\subsubsection{Solid Waste}

The transmissivity obtained for both observation wells was $3 \mathrm{~cm}^{2} / \mathrm{sec}$ and are shown on Table 5 and depicted on appropriate units in Figures 10 and 11. Complete Aqtesolv spreadsheets are attached in Appendix C. The specific yield values based on the pumping test results were 2.8 and 3.8\%. These values are relatively low for specific yields in general, but are considered typical for the solid waste material in this study (silt and clay sized particles). At a typical porosity of $78 \%$ for the solid waste, $75 \%$ of the material would consist of non-drainable pore space. 
Because the steady state was achieved during the test, the final drawdowns can be used to compute a radius of influence for the pumping well. The steady state radius of influence is estimated at $70 \mathrm{~m}$ based on the final drawdown data.

\section{Table 5. Pumping Test Results}

Pumping test results, the solution used for each test and how well the curve matched the data.

\begin{tabular}{|c|c|c|c|c|c|}
\hline & & & Transmissivity & Solution & $\begin{array}{l}\text { Match } \\
\text { Quality }\end{array}$ \\
\hline Well & Location & Test Type & $\mathrm{cm}^{2} / \mathrm{sec}$ & & \\
\hline $12-10$ & Landfill & Multi-well Pumping Test & 2.E-01 & Neuman & Very good \\
\hline $12-10 \mathrm{~A}$ & Landfill & Multi-well Pumping Test & 3. $E+00$ & Cooper-Jacob & Good \\
\hline $12-10 b$ & Landfill & Multi-well Pumping Test & $3 . E+00$ & Cooper-Jacob & Good \\
\hline MW-103B & Ridgeline & Single well Pumping Test & 6.E-01 & Theis & Very good \\
\hline MW-103B & Ridgeline & Multi-well Pumping Test & 3.E-01 & Theis & Fair \\
\hline MW-102B & Ridgeline & Multi-well Pumping Test & 3.E-01 & Cooper-Jacob & Very good \\
\hline MW-105B & Ridgeline & Multi-well Pumping Test & 4.E-01 & Theis & Good \\
\hline MW-107B & Ridgeline & Multi-well Pumping Test & 3.E-01 & Theis & Good \\
\hline MW-116B & Ridgeline & Multi-well Pumping Test & 4.E-01 & Theis & Good \\
\hline OW-112B & Ridgeline & Multi-well Pumping Test & 3.E-01 & Theis & Good \\
\hline
\end{tabular}

\subsubsection{Bedrock}

Drawdowns during the MW-103B pumping test, which is screened in the coal seam, did not achieve steady state during the pumping test in bedrock. The wells completed in the coal exhibited a transmissivity of $0.3 \mathrm{~cm}^{2} / \mathrm{sec}$. Using the thickness of the Mahoning coal at the individual well locations, the transmissivities translate to a hydraulic conductivity of $2 \times 10^{-3}$ $\mathrm{cm} / \mathrm{sec}$. The low storage coefficient is consistent with confined conditions. A steady-state radius of influence cannot be accurately projected because steady-state conditions were not achieved. However, the drawdowns that were observed indicate that such a radius will be substantial, in excess of $460 \mathrm{~m}$ (Figure 12).

Drawdown during the MW-112 pumping test, which is screened across multiple layers, achieved steady state. Observation piezometers OW-112B, which is screened in the Brush Creek coal seam, showed a transmissivity of $0.2884 \mathrm{~cm}^{2} / \mathrm{sec}$. Using this transmissivity, and the thickness of the Brush Creek coal seam in the investigation area the transmissivity translates to a hydraulic conductivity range of $4 \times 10^{-3}$ to $8 \times 10^{-3} \mathrm{~cm} / \mathrm{sec}$. 


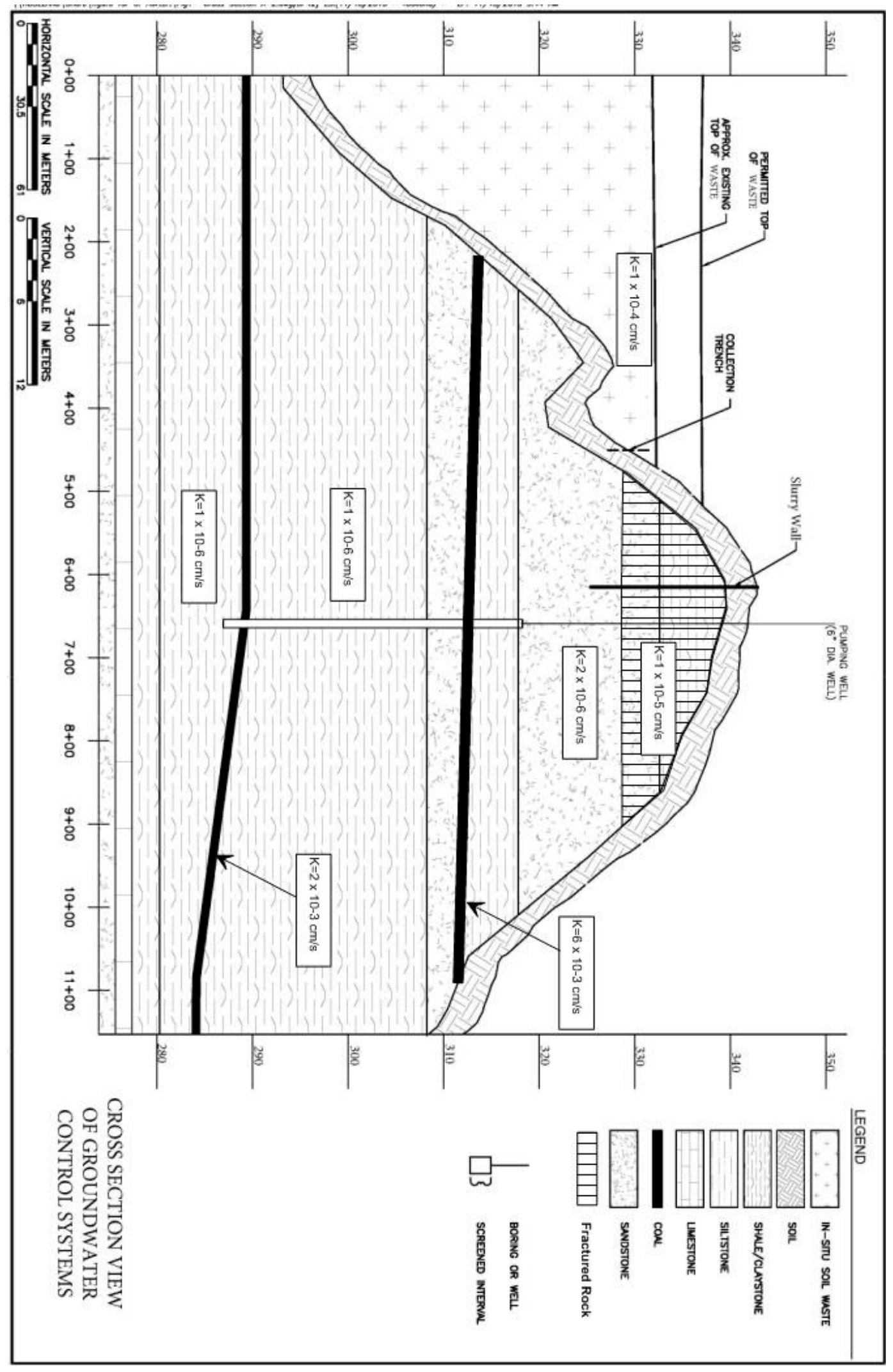

Figure 10. Cross Section A of Research Area

Cross Section A from Figure 4 showing the calculated hydraulic conductivities for tested wells. 


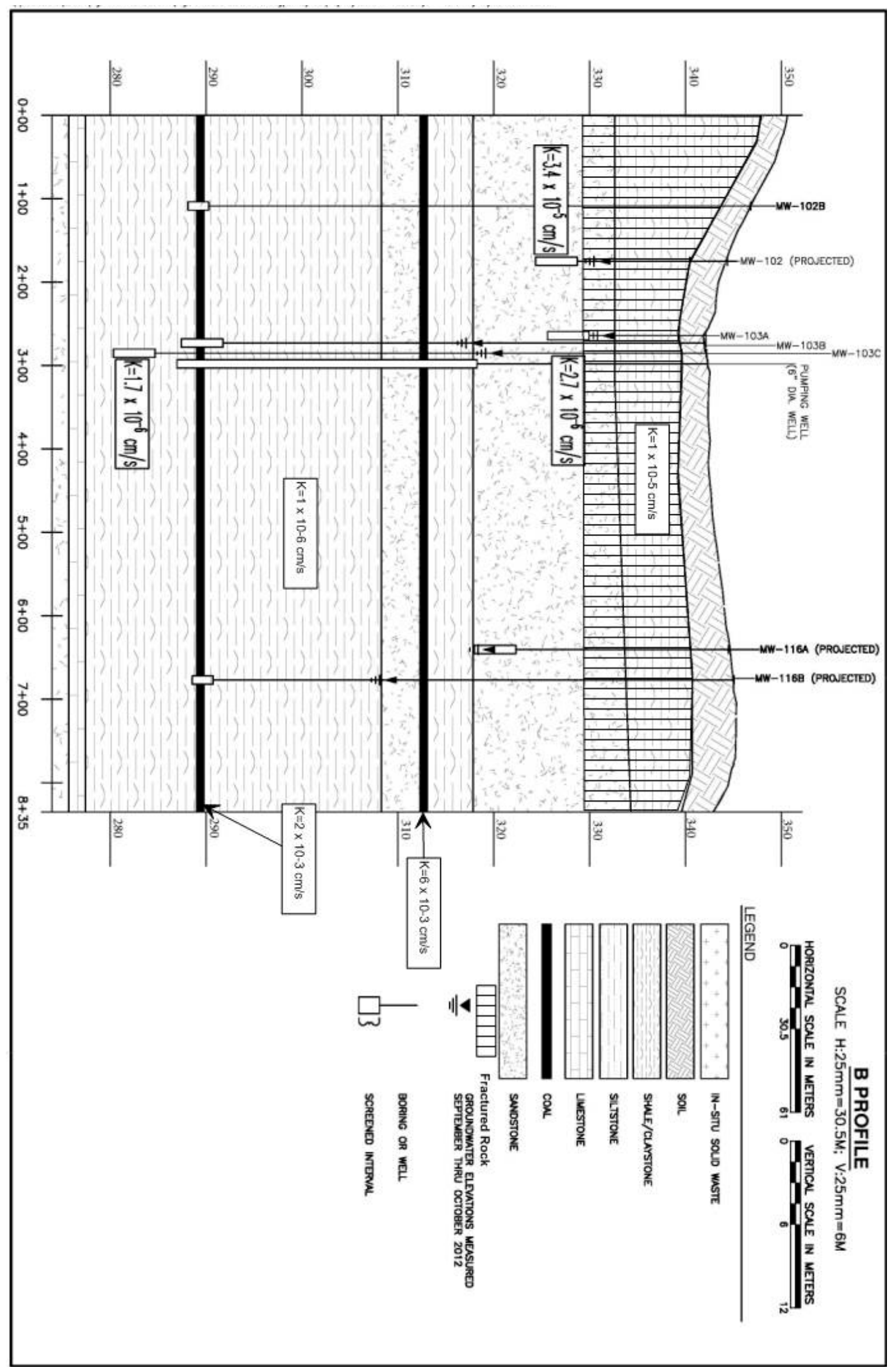

Figure 11. Cross Section B of Research Area

Cross Section B from Figure 4 showing calculated hydraulic conductivities from tested wells. 


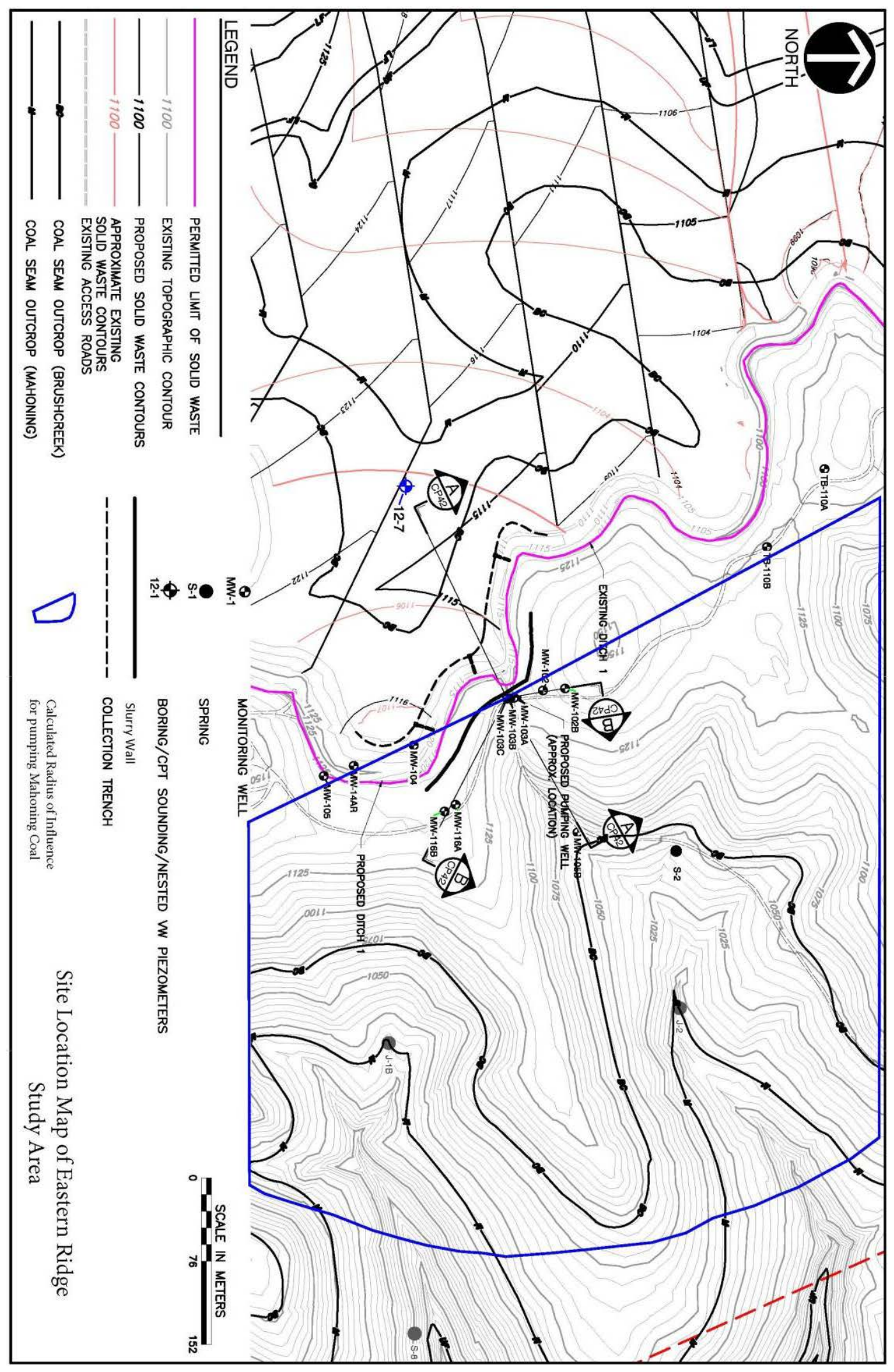

Figure 12. Radius of Influence Map

Radius of influence from pumping test in Mahoning Coal seam. 


\subsection{PERTURBATIONS IN GROUNDWATER CONTROL TECHNOLOGIES}

\subsubsection{Pumping Trench}

On August 18, 2014 the two pumps in the pumping trench stopped working and the trench was only pumped on the northern and southern edge. The pumps were not reinstalled until October 6, 2014. In the months following the pumping trench failure, Spring-2 water chemical concentrations increased for chloride, calcium, magnesium and sulfate (Figure 13). In contrast, concentrations in Spring-1 stayed relatively stable (Figure 13). 

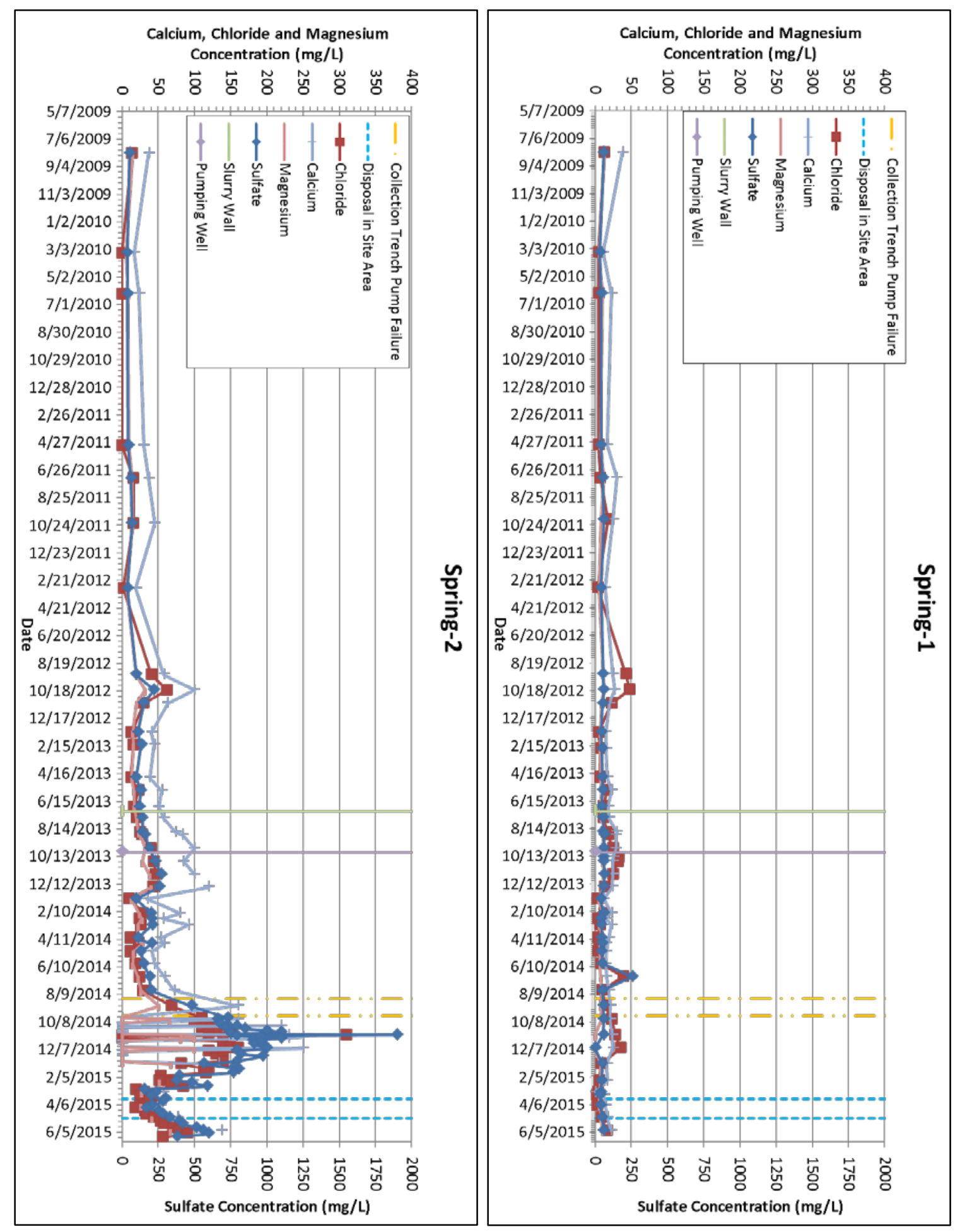

Figure 13. Water Quality at Spring-1 and Spring-2

Concentrations increase in Spring-2 after the pump failure in the collection trench August 2014.

It appears that when the pumping trench failed calcium, magnesium, chloride, and sulfate concentrations increased in Spring-2 even with the continuous operation of the groundwater 
pumping well. Groundwater pumping on the ridge has been continuous from October 2013 through the end of the research period in June 2015. Both piezometer PZ-103 and monitoring well MW-103A (installed next to the pumping well) had an approximate $0.5 \mathrm{~m}$ rise in groundwater elevation when the center pump in the pumping trench failed in August 2014 (Figure 14). In December 2014 groundwater levels rose 1.5 to $2.0 \mathrm{~m}$. This can be attributed to more rain during this time period. The groundwater elevations returned to previous levels in February 2015. Groundwater elevations increased again in March 2015 (Figure 14).

The increase in groundwater elevation in March 2015 was caused by the resumption of solid waste disposal in the study area. Disposal continued until May 2015 and groundwater levels returned to the $336 \mathrm{~m}$ to $337 \mathrm{~m}$ amsl range. This shows that during disposal water levels in front of the pumping well increased to the $337.5 \mathrm{~m}$ amsl range with a maximum level measurement of $339 \mathrm{~m}$ amsl on April 10, 2015. Concentrations of chloride, magnesium and sulfate in Spring-2 increased and maxed out on June 8, 2015. Sulfate levels went from $206 \mathrm{mg} / \mathrm{L}$ to $598 \mathrm{mg} / \mathrm{L}$, magnesium levels increased from $25.8 \mathrm{mg} / \mathrm{L}$ to $67 \mathrm{mg} / \mathrm{L}$, calcium levels increased from $53.2 \mathrm{mg} / \mathrm{L}$ to $138 \mathrm{mg} / \mathrm{L}$, and chloride levels increased from $18.3 \mathrm{mg} / \mathrm{L}$ to $90.1 \mathrm{mg} / \mathrm{L}$. At the June 15, 2015 sampling event concentrations decreased in sulfate $(382 \mathrm{mg} / \mathrm{L})$ and chloride $(55.8 \mathrm{mg} / \mathrm{L})$ (Figure 13). 

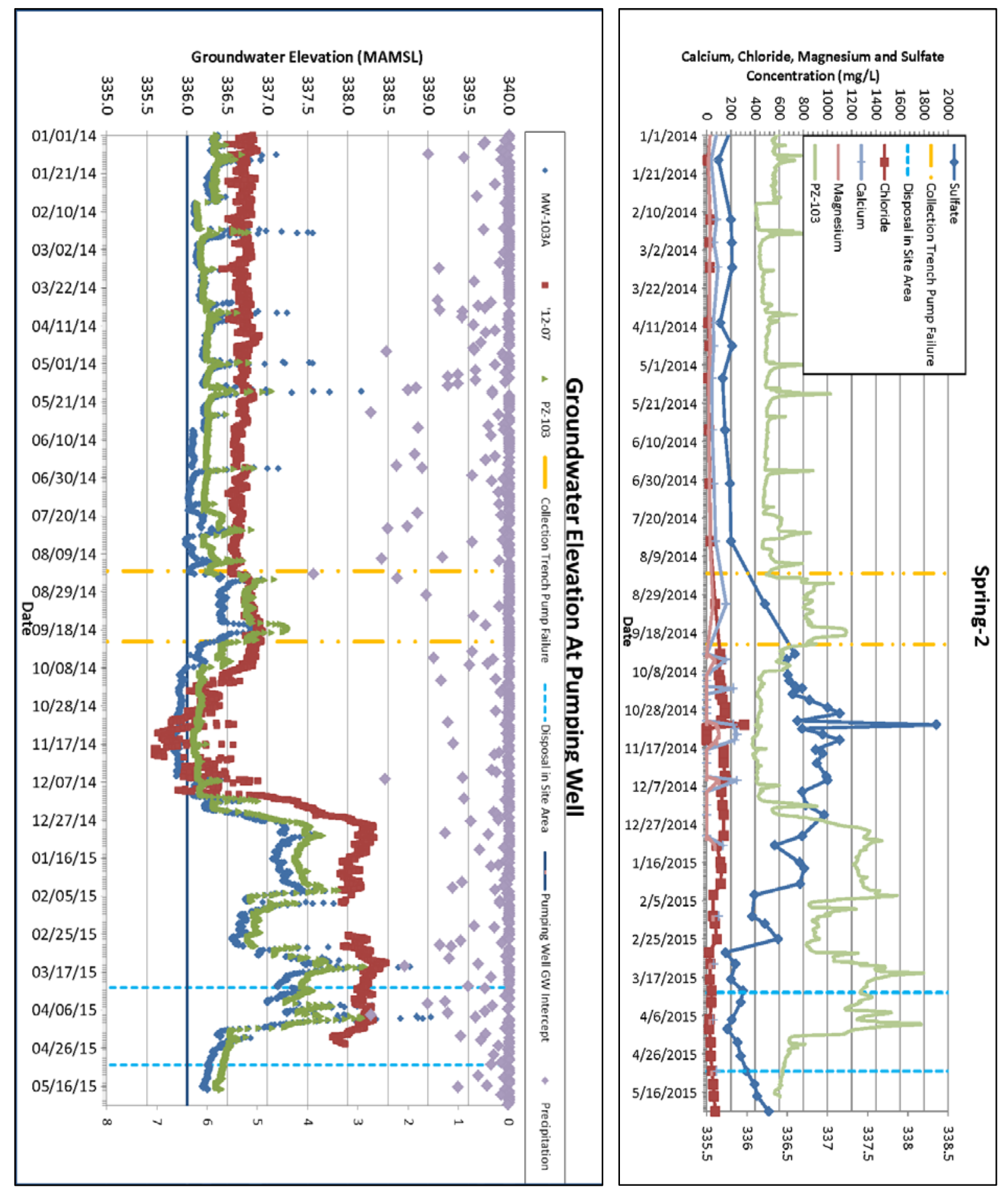

Figure 14. Spring-2 Water Quality Compared to Groundwater Elevations

Groundwater Elevations in the landfill and at the Pumping well compared to daily precipitation, and the water chemistry at Spring-2. 


\subsection{DISCUSSION OF AQUIFER PROPERTIES AND WATER QUALITY}

The transmissivity value from the pumping test in the solid waste was on the same order of magnitude as the average of the high end slug test values $\left(10^{-4}\right)$. It is not unusual for slug tests to estimate lower hydraulic conductivity values than pumping tests, because the pumping test reflects a larger volume of material and a greater number of natural discontinuities. Based on pumping tests conducting in the landfill the solid waste material has an in-situ effective hydraulic conductivity of $9.7 \times 10^{-4} \mathrm{~cm} / \mathrm{sec}$.

The bulk of the rock mass, excluding the fractured bedrock, in the ridge exhibits a relatively low hydraulic conductivity, with a median hydraulic conductivity of $10^{-6} \mathrm{~cm} / \mathrm{sec}$. Permeability decreases with depth due increased overburden pressure and decreased weathering, and stress relief. The higher permeabilities are related to fracture traces and coal beds. The fractured bedrock exhibited a hydraulic conductivity in the $10^{-5} \mathrm{~cm} / \mathrm{sec}$ range. These measurements indicate that the fracture traces likely transmit groundwater through the ridge at a much greater rate than the bulk rock mass.

The saddle in the ridge alone is an indication that groundwater might preferentially flow through this area. The saddle would indicate that the rock below it was weaker (e.g., fractured) which caused preferential weathering and resulted in the saddle. Secondary permeability due to jointing and stress-release fracturing accounts for most of the porosity and permeability in the Appalachian Plateau creating drainage nets (Seaber et al, 1988). When the rock mass above the saddle was removed, this accentuated the process as the compression on the rock was further reduced, likely causing additional fracturing. This fracturing is a potential preferential pathway for the contaminated groundwater flow along the ridge, further complicating the hydrogeology.

Under the conditions on our site, our results indicate the majority of contaminated groundwater flows through the fractured bedrock. This has been determined based on several observations:

1. When the pumping trench (which is set in fractured bedrock) failed, the concentrations of calcium, magnesium, chloride and sulfate increased in Spring-2 (Figure 10 and 13). 
Chloride and sulfate concentrations exceeded the PADEP chapter 93 Water Quality Standards (Standards) of $250 \mathrm{mg} / \mathrm{l}$.

2. While the pumping trench was operating at $1 / 3$ capacity, and the pumping well (which is set in the coal seams and sandstone) did not prevent the concentrations of calcium, magnesium, chloride and sulfate from increasing in Spring-2. This indicates that while the coal seams have a high hydraulic conductivity they do not seem to transport the bulk of the contaminated groundwater flow through the ridge.

3. The slurry wall does not seem to prevent contaminated groundwater flow through the fractured bedrock. Ultimately, it was installed to slow down flow through the fractured rock, however, our data do not allow assessment of how effective this slowing is.

A rock unit having the highest hydraulic conductivity does not necessarily mean it will be the preferential flow pathway. In addition to the observations above, Spring- 1 is located in a similar arrangement with the coal to Spring-2, but further from the saddle. Limited water quality effects at Spring-1 throughout the sampling period are consistent with primary contaminated groundwater transmission through the fractured rock, particularly in the saddle. This flow through the fractured zone may arise for several reasons. While the hydraulic conductivity of the coal $\left(\sim 10^{-3} \mathrm{~cm} / \mathrm{sec}\right)$ is higher than the fractured bedrock $\left(\sim 10^{-5} \mathrm{~cm} / \mathrm{sec}\right)$ but the compression levels of the coals seams are higher given their relative depth, and the coal seams are thin, particularly relative to the fractured rock. Based on the depth of the fractured rock versus the coal seam (12 m thick for the fractured rock on the ridge and $71 \mathrm{~cm}$ thick for the coal seam), the relative thickness of the aquifer materials, and the potential for a concentrated zone of fracturing in the saddle, it seems reasonable that the majority of groundwater flow could occur through the fractured rock.

Using the failure of the pumping trench in August to October 2014 as an unintended experiment, the effectiveness of the pumping well can be examined. Because the slurry wall does not remove groundwater flow through the ridge, the pumping well was the primary mechanism to limit contaminated groundwater flow through the ridge to Spring-2. The concentrations in the spring water during this time period indicate that the pumping well did not control the flow of contaminated groundwater through the ridge (Figure 13). Using the hydraulic conductivity of $10^{-5} \mathrm{~cm} / \mathrm{sec}$ and assuming a porosity of 0.1 (for fractured rock), a pore water velocity of 0.1 meters per day was calculated. Based on this, it was determined that when the pumping trench failed it 
would take contaminated groundwater approximately 2,580 days to travel to Spring-2. The pumping trench failed on August 18, 2014 (Figure 13) and concentrations of calcium, chloride, magnesium, and sulfate all increased at the next sampling event on September 3, 2014. The pumping trench resumed operation on September 24, 2014. Concentrations continued to increase until November 5, 2014 (42 days after pumping resumed) before starting to decrease. This rapid change in spring water chemistry suggests that the primary flow path through the ridge is through macropores and fractures in the rock. Pumping tests of the fractured bedrock were not conducted and this fast flow could have been missed by the slug testing.

To determine if Spring-1 was impacted by the contaminated groundwater and ensure that the coal seams are not the preferential flow pathway for contaminated groundwater flow, water quality from October 16, 2012 was examined. Comparison of water quality between Spring-1 and Spring-2 from October 16, 2012 reveals specific differences in contaminant concentrations. If the source of water at Spring-1 and Spring-2 were the same, they should have similar relative concentrations of analytes. However, Spring-1 concentrations of chloride, sodium, magnesium, calcium, and sulfate on October 16, 2012 were similar to historic concentrations with lower concentrations of alkalinity (Table 2). Spring-2 has a higher concentration of calcium and sulfate relative to the magnesium, sodium, chloride and alkalinity concentrations (Table 2). When comparing water quality at Spring-1 and Spring-2 to landfill water (Figure 15), Spring-2's radial plot shape is closer to the shape of the landfill water radial plot than to Spring-1's radial plot, particularly in the concentrations of calcium and sulfate. This indicates that in addition to contrasts in concentration magnitude, the source of water constituents are likely distinct. This comparison is evidence that the coal seams are not the preferential flow path for the contaminated groundwater. Further, the similarity between Spring-2 and the landfill water radial plot shapes suggests that water quality at Spring-2 is be affected by the landfill. To further show that Spring-1 is not impacted by the landfill the radial plots from 10/16/12 and 11/5/14 are compared (Figure 15 and 16). The plot shapes for Spring-1 are similar in shape and magnitude. When comparing the radial plots for Spring-2 from 10/16/12 and 11/5/14 (Figures 15 and 16) there is a large increase in sulfate concentrations because of the increased flow from the landfill. The calcium sulfate concentration magnitude at Spring-2 on 11/5/14 is similar to the landfill water (Figure 16).

Another way to analyze the differences in contaminant concentrations in Spring-1, Spring-2, and the landfill is examining associations between contaminants. Figure 17 shows the 
association between sulfate and alkalinity during the research period at Spring-1, Spring-2, and the landfill water. The association at Spring-1 stays relatively consistent throughout the research period. Apart from some outliers, the landfill water shows a relatively consistent sulfate to alkalinity association throughout the research period. The association for Spring-2 samples through August 1, 2014 show similar sulfate to alkalinity associations as the Spring-1 data. After August 1, 2014 the sulfate to alkalinity associations start migrating toward associations found in the landfill water. This evolution in water chemistry suggests that 1) the water feeding Spring-1 receives relatively minimally contributions from the solid waste landfill when compared to Spring-2.

The calculated travel time of impacted water in the landfill to Spring-1 is the same as Spring-2. Using the calculation discussed above for travel time to Spring-2, it was determined that it would also take impacted water 2,580 day. This indicates that Spring-1 is not tied to the landfill by fractures like it appears to be the case at Spring-2.

Examining the water quality at Spring-2 over time allows evaluation of the effectiveness of the pumping trench. Specifically, using water quality data around the time of the pumping trench failure can help with this. Prior to the pump failure, while solid waste disposal was not occurring near the ridge area, the collection trench appears to prevent sufficient contaminant flow through the saddle in the ridge, as water chemistry remains under permitted concentrations during this period. Concentrations of chloride and sulfate exceeded the Standards of $250 \mathrm{mg} / \mathrm{l}$ at Spring-2 on November 15, 2014 before dropping below the standards again even though the pumping trench resumed operation on September 24, 2014. On March 25, 2015, near the end of the research period, disposal resumed near the ridge while the pumping trench was in operation. Concentrations of calcium, magnesium, chloride, and sulfate started to increase again (Figure 13). The water quality data before March 25, 2015 shows that the collection trench helps reduce contaminant flow through the ridge when disposal is not occurring near the research area.

Due to the location of the slurry wall it seems to be of limited effectiveness. The slurry wall was installed down gradient of the pumping trench so even if the slurry wall slows down groundwater flow through the fractured rock the pumping trench will not necessarily remove the contaminated groundwater. The pumping well is installed in the sandstone and coal seams so it 
will not remove the contaminated groundwater from the fractured rock that the slurry wall is slowing down.

The ultimate goal of this system was minimizing the flow of contaminated groundwater to Spring-2 and keep contamination levels downstream below PADEP approved levels. Based on the Standards the maximum allowable concentrations for chloride and sulfate in surface water is $250 \mathrm{mg} / \mathrm{L}$. Chloride levels in Spring-2 only exceeded the Standards of $250 \mathrm{mg} / \mathrm{L}$ on November 15, 2014 and continued to be below the Standard through June 2015. Prior to additional disposal of material in the Site area starting in March 2015, sulfate levels were reduced to below $250 \mathrm{mg} / \mathrm{L}$ in Spring-2. After disposal in the Site area was resumed, the sulfate levels increased to concentrations over $250 \mathrm{mg} / \mathrm{l}$. Disposal was ceased in the Site area in May 2015. Sulfate levels reached a maximum concentration of $598 \mathrm{mg} / \mathrm{l}$ on June 8, 2015 then decreased to $382 \mathrm{mg} / \mathrm{l}$ on June 15, 2015. If the water quality downstream of the site exceed the PADEP SWQS fines will be issued, and if the concentrations exceed for an extended period of time the discharge permit could be revoked. If this happens the operator of the landfill will no longer be able to dispose of waste in the research area.

It is assumed that when the landfill is closed and the waste is capped, the pumping trench effectiveness will increase and eventually no longer be necessary. Eventually (model estimates are 3-5 years) the landfill will be dewatered to levels where groundwater elevations are below the collection trench, and the pumps will be turned off. When the water levels in the landfill drop below the fractured bedrock water quality at Spring-2 is expected to eventually return to background conditions. 


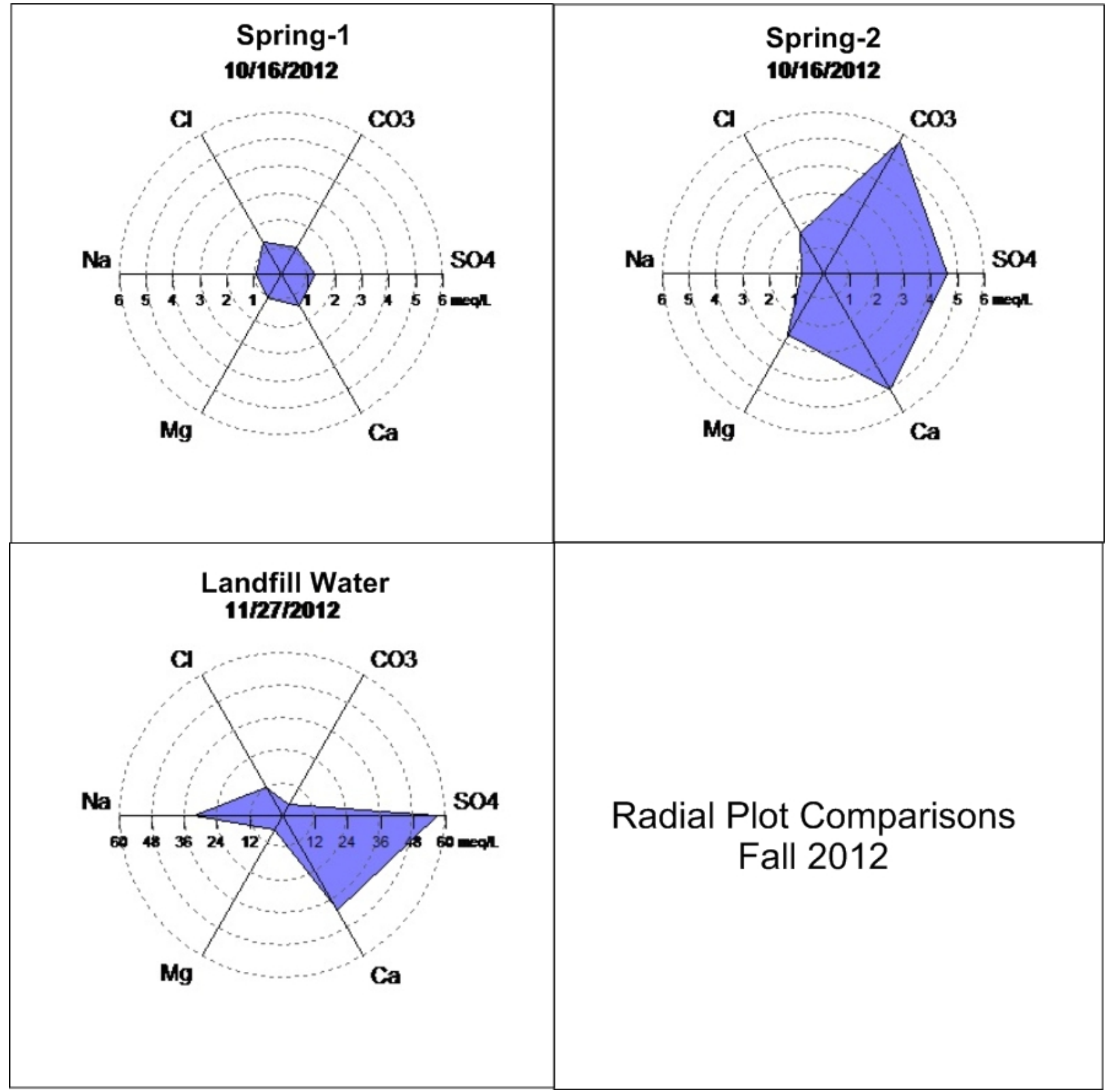

Figure 15. Radial Plots of Water Quality-Fall 2012

Radial plots of water quality at Spring-1, Spring-2 on 10/16/12 and the landfill water on $11 / 27 / 12$. 


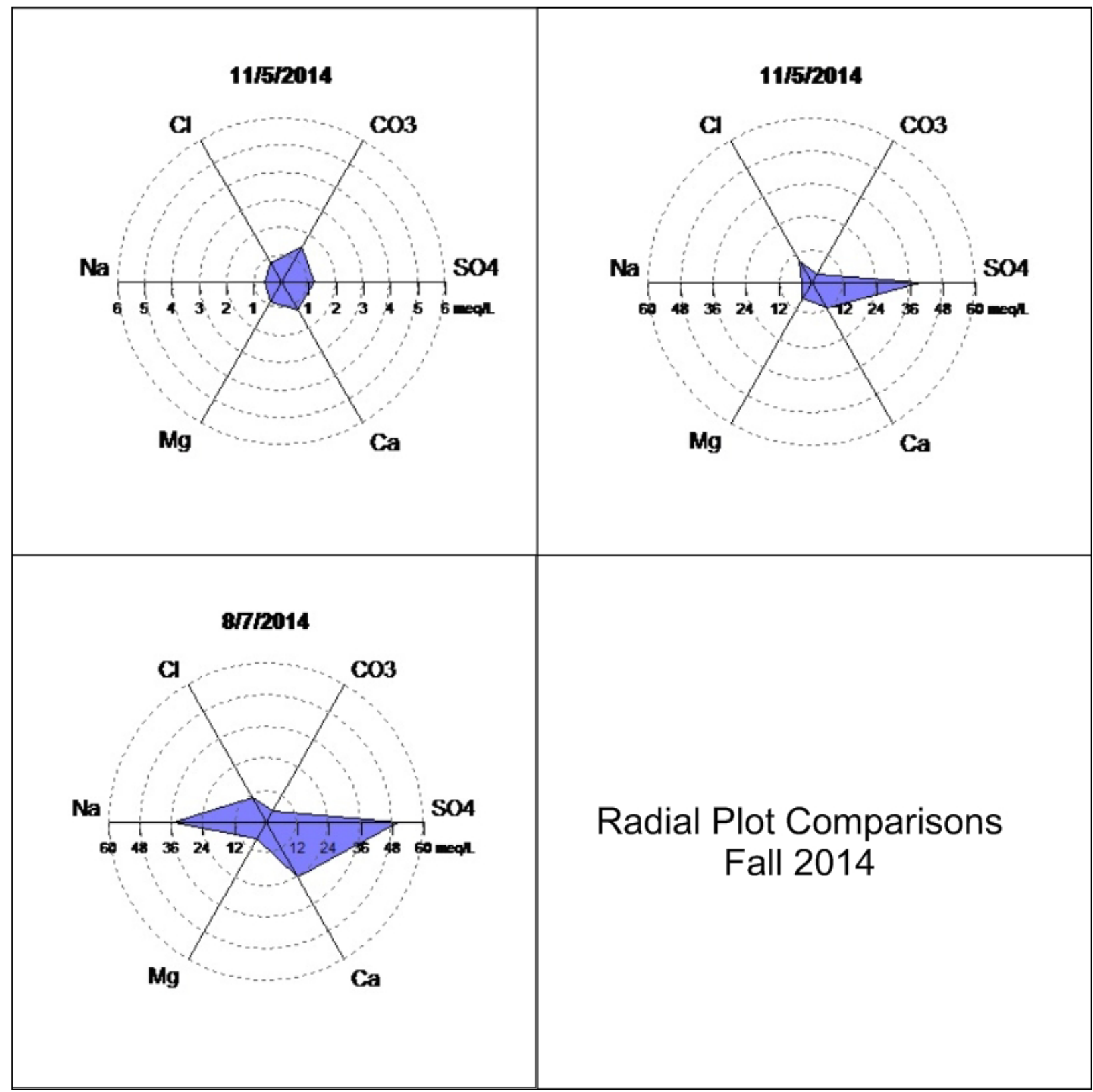

Figure 16. Radial Plots of Water Quality-Fall 2014

Radial Plots of Spring-1, Spring-2 and the landfill after the pump failed in the collection trench. 


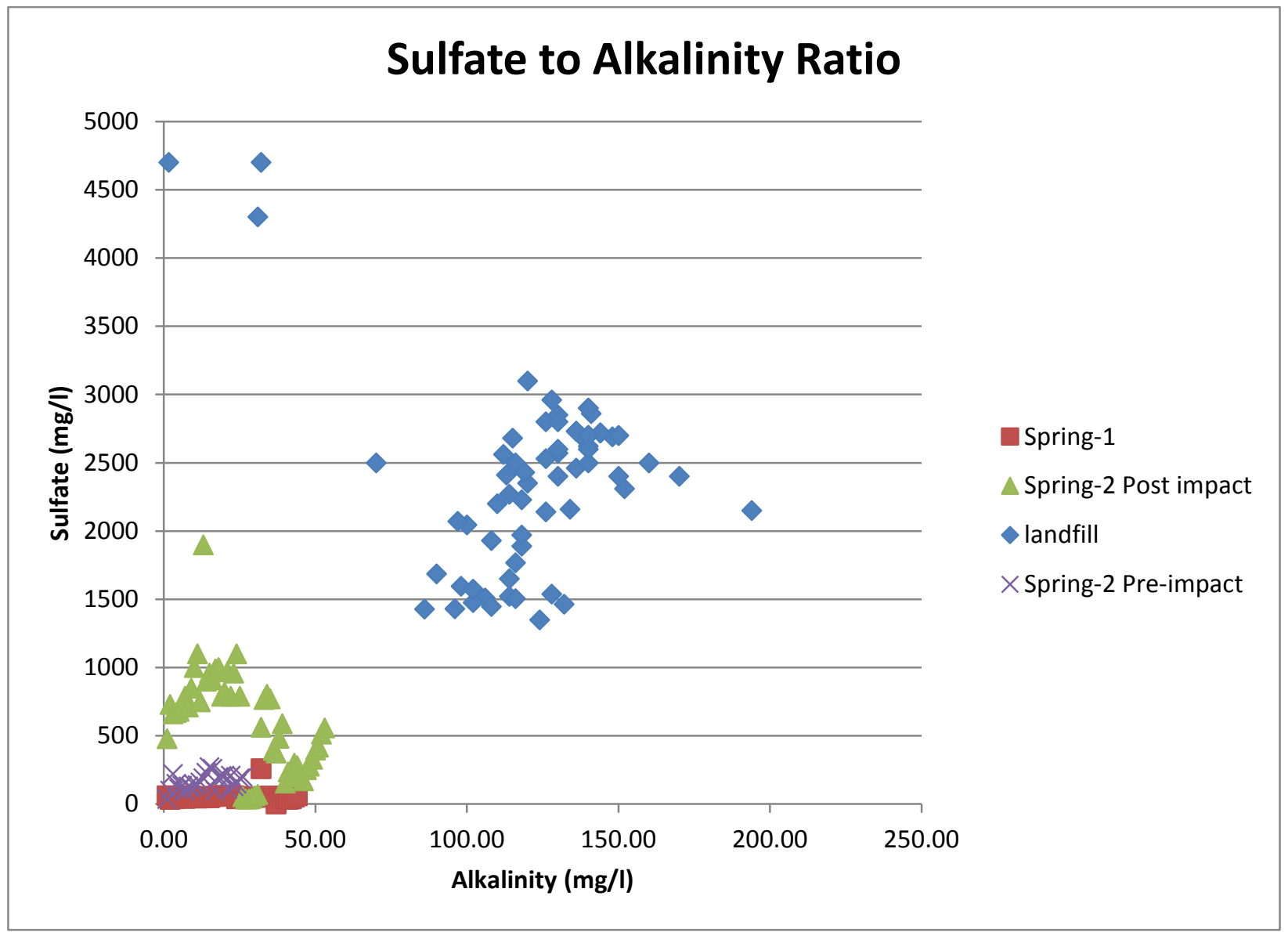

Figure 17. Sulfate to Alkalinity Comparison

Alkalinity to Sulfate association at Spring-1, Spring-2 pre-impact, Spring-2 post impact, and the landfill during the research period. 


\subsection{CONCLUSIONS}

This research suggests that a system of groundwater control devices is not necessarily effectively preventing contaminated groundwater flow from a legacy landfill. The majority of contaminated groundwater flow appears to move through the fractured rock zones, contrary to designer expectations. This reality makes the collection trench the most effective control system. The preliminary evaluation before the groundwater control system was installed underestimated the flow through the fractured system and overestimated the flow through the coal seams. The differences between design and function diminished effectiveness in groundwater control.

Regardless of shortcomings in function, this site remains a challenge to manage. Topographic constraints in the site area prevent installation of potentially more optimal configurations (e.g., Bayer, 2006.) Installation of multiple control devices in this sort of complex hydrogeologic setting remains the best way to address these challenges. This measurement of system effectiveness reveals that models can guide design, but heterogeneity and unconformities are fundamentally important to successful groundwater control.

This research was conducted to determine if the three groundwater control systems were effective working in conjunction to control the flow of impacted groundwater from the landfill. Follow-up work may be conducted to examine the geochemical effects of the coal seams on the impacted groundwater. The coal seams could be acting as filters that are reducing concentrations of the impacted water as it flows through the coal seams. Additionally, this research was conducted over 3 years. Based on the calculated flows through the fractured rock Spring- 1 could become impacted by the landfill in the future which will be observed from continued sampling. 
APPENDIX A

WATER QUALITY DATA 


\begin{tabular}{|c|c|c|c|c|c|c|c|c|c|c|c|}
\hline Date Sampled: & \begin{tabular}{|c|} 
Spring-1 \\
$8 / 6 / 2009$ \\
\end{tabular} & \begin{tabular}{|c|} 
Spring-1 \\
$3 / 11 / 2010$ \\
\end{tabular} & \begin{tabular}{|c|} 
Spring-1 \\
$6 / 9 / 2010$ \\
\end{tabular} & \begin{tabular}{|c|} 
Spring-1 \\
$5 / 4 / 2011$ \\
\end{tabular} & \begin{tabular}{|c|} 
Spring-1 \\
$7 / 14 / 2011$ \\
\end{tabular} & \begin{tabular}{|c|} 
Spring-1 \\
$10 / 13 / 2011$ \\
\end{tabular} & \begin{tabular}{|c|} 
Spring-1 \\
$3 / 9 / 2012$ \\
\end{tabular} & $\begin{array}{c}\text { Spring-1 } \\
9 / 13 / 2012\end{array}$ & \begin{tabular}{|c|} 
Spring-1 \\
$10 / 16 / 2012$ \\
\end{tabular} & \begin{tabular}{|c|} 
Spring-1 \\
$11 / 15 / 2012$ \\
\end{tabular} & \begin{tabular}{|c|} 
Spring-1 \\
$1 / 17 / 2013$ \\
\end{tabular} \\
\hline \multicolumn{12}{|l|}{ Field Parameters } \\
\hline Flow (gpm) & & & & & & & & & 2 & 3 & 25 \\
\hline pH (S.U.) & 7.37 & 6.31 & 6.5 & & 7.5 & 7.63 & 7.44 & 7.54 & 6.95 & 6.93 & 6.81 \\
\hline ORP (mV) & 92 & 137 & 184 & & 22 & 46.1 & 139 & 28.9 & 89.6 & 39 & 41.7 \\
\hline Dissolved Oxygen (mg/l) & & & & & & & & 7.84 & 5.6 & & 10.12 \\
\hline Conductivity (umhos/cm) & 313.8 & 135.6 & 187.9 & & 269 & 332 & 155.9 & 339 & 314 & 290.6 & 152 \\
\hline Temperature (C) & 16.5 & 4.2 & 14.3 & & 19.43 & 16.95 & 6.2 & 21.89 & 12.78 & 6.6 & 6.54 \\
\hline \multicolumn{12}{|l|}{ Dissolved Metals (mg/l) } \\
\hline \multicolumn{12}{|l|}{ Aluminum } \\
\hline \multicolumn{12}{|l|}{ Antimony } \\
\hline \begin{tabular}{|l|} 
Arsenic \\
\end{tabular} & & & & & & & & $<0.001$ & $0.00099 \mathrm{~J} \mathrm{~B}$ & & \\
\hline Barium & & & & & & & & $0.068 \mathrm{~B}$ & 0.066 & & \\
\hline Beryllium & & & & & & & & & & & \\
\hline Boron & & & & & & & & $0.079 \mathrm{~B}^{\wedge}$ & $0.036 \mathrm{~B}$ & & \\
\hline Cadmium & & & & & & & & $<0.001$ & $<0.001$ & & \\
\hline \begin{tabular}{|l} 
Calcium \\
\end{tabular} & & & & & & & & $27 \mathrm{~B}$ & 27 & & \\
\hline Chromium & & & & & & & & $0.0005 \mathrm{~J}$ & $0.00026 \mathrm{~J}$ & & \\
\hline Cobalt & & & & & & & & & & & \\
\hline Copper & & & & & & & & $0.0011 \mathrm{~J} \mathrm{~B}$ & $0.00066 \mathrm{~J}$ & & \\
\hline Cyanide & & & & & & & & & $<0.01$ & & \\
\hline Iron & & & & & & & & $0.0071 \mathrm{~J}$ & $0.015 \mathrm{JB}$ & & \\
\hline Lead & & & & & & & & $0.000021 \mathrm{JB}$ & $0.000049 \mathrm{~J}$ & & \\
\hline Magnesium & & & & & & & & $12 \mathrm{~B}$ & $12 \mathrm{~B}$ & & \\
\hline Manganese & & & & & & & & $0.11 \mathrm{~B}$ & 0.1 & & \\
\hline \begin{tabular}{|l|} 
Mercury \\
\end{tabular} & & & & & & & & $<0.0002$ & $<0.0002$ & & \\
\hline Molybdenum & & & & & & & & $0.0015 \mathrm{JB}$ & $0.00029 \mathrm{~J} \mathrm{~B}$ & & \\
\hline Nickel & & & & & & & & & & & \\
\hline Potassium & & & & & & & & $2.6 \mathrm{~B}$ & $2.2 \mathrm{~B}$ & & \\
\hline Selenium & & & & & & & & $<0.005$ & $0.0022 \mathrm{JB}$ & & \\
\hline \begin{tabular}{|l|} 
Silver \\
\end{tabular} & & & & & & & & $<0.001$ & $<0.001$ & & \\
\hline Sodium & & & & & & & & $20 \mathrm{~B}$ & $22 \mathrm{~B}$ & & \\
\hline Thallium & & & & & & & & $0.00015 \mathrm{JB}$ & $<0.001$ & & \\
\hline Vanadium & & & & & & & & & & & \\
\hline Zinc & & & & & & & & $0.0066 \mathrm{~B}$ & $0.0049 \mathrm{~J}$ & & \\
\hline Total Metals (mg/l) & & & & & & & & & & & \\
\hline Aluminum & & & & & & & & & & & \\
\hline Antimony & & & & & & & & & & & \\
\hline \begin{tabular}{|l|} 
Arsenic \\
\end{tabular} & 0.0042 & $<0.0025$ & 0.0058 & $<0.0025$ & $<0.0025$ & $<0.0025$ & $0.0002 \mathrm{~J}$ & $0.0012 \mathrm{~B}$ & $0.0015 \mathrm{~B}$ & $0.00016 \mathrm{~J}$ & $<0.001$ \\
\hline Barium & & & & & & & & 0.065 & 0.066 & & \\
\hline Beryllium & & & & & & & & & & & \\
\hline \begin{tabular}{|l|} 
Boron \\
\end{tabular} & $<0.1$ & $<0.1$ & $<0.1$ & $<0.1$ & $<0.1$ & $<0.1$ & 0.021 & $0.036 \mathrm{~B}$ & $0.035 \mathrm{~B}$ & $0.026 \mathrm{~B}$ & $0.033 \mathrm{~B}$ \\
\hline Cadmium & & & & & & & & $<0.001$ & $<0.001$ & & \\
\hline \begin{tabular}{|l} 
Calcium \\
\end{tabular} & 38 & 11 & 23 & 17 & 30 & 25 & 14 & 25 & 27 & 20 & 15 \\
\hline Chromium & & & & & & & & $0.00024 \mathrm{~J}$ & $0.00023 \mathrm{~J}$ & & \\
\hline Cobalt & & & & & & & & & & & \\
\hline Copper & & & & & & & & $0.0009 \mathrm{~J}$ & $0.00055 \mathrm{~J}$ & & \\
\hline Cyanide & & & & & & & & & $<0.01$ & & \\
\hline \begin{tabular}{|l|l|} 
Iron \\
\end{tabular} & 8.2 & 0.75 & 14 & 0.47 & 0.64 & 0.13 & $0.29 \mathrm{~B}$ & $0.048 \mathrm{~J}$ & $0.09 \mathrm{~B}$ & 0.072 & $0.23 \mathrm{~B}$ \\
\hline \begin{tabular}{|l|} 
Lead \\
\end{tabular} & & & & & & & & $0.000052 \mathrm{JB}$ & $0.000023 \mathrm{~J}$ & & \\
\hline Magnesium & 13 & 5.9 & 10 & 7.3 & 12 & 8.9 & 6.1 & \begin{tabular}{|l|}
11 \\
\end{tabular} & 12 & 9 & 7.1 \\
\hline Manganese & 0.59 & 0.55 & 0.54 & 0.031 & 0.19 & 0.032 & 0.02 & 0.11 & 0.17 & 0.03 & $0.032 \mathrm{~B}$ \\
\hline \begin{tabular}{|l|} 
Mercury \\
\end{tabular} & $<0.0008$ & $<0.0008$ & $<0.0008$ & $<0.0008$ & $<0.0008$ & $<0.0008$ & $<0.0002$ & $<0.0002$ & $<0.0002$ & $<0.0002$ & $<0.0002$ \\
\hline Molybdenum & & & & & & & & $0.0011 \mathrm{JB}$ & $<0.005$ & & \\
\hline Nickel & & & & & & & & & & & \\
\hline \begin{tabular}{|l|} 
Potassium \\
\end{tabular} & 3.4 & 1.8 & 4.2 & 1.5 & 3.5 & 2.1 & $1 \mathrm{~B}$ & 2.4 & $2.2 \mathrm{~B}$ & 1.3 & $1.1 \mathrm{~B}$ \\
\hline Selenium & & & & & & & & $0.0041 \mathrm{JB}$ & $0.0044 \mathrm{JB}$ & & \\
\hline \begin{tabular}{|l|} 
Silver \\
\end{tabular} & & & & & & & & $<0.001$ & $<0.001$ & & \\
\hline Sodium & 5.3 & 2.9 & 2.6 & 4.8 & 9.4 & 6.9 & $4 \mathrm{~B}$ & 19 & $21 \mathrm{~B}$ & $15 \mathrm{~B}$ & $5.3 \mathrm{~B}$ \\
\hline Thallium & & & & & & & & $0.000093 \mathrm{~J}$ & $<0.001$ & & \\
\hline Vanadium & & & & & & & & & & & \\
\hline Zinc & & & & & & & & 0.0083 & $0.0027 \mathrm{~J}$ & & \\
\hline General Chemistry (mg/l unless otherwise noted) & & & & & & & & & & & \\
\hline Ammonia & 0.15 & $<0.050$ & $<0.05$ & 0.096 & 0.078 & 0.069 & $0.22 \mathrm{~B}$ & $0.25 \mathrm{~B}$ & $0.098 \mathrm{~J} \mathrm{~B}$ & & \\
\hline Total Alkalinity & 73 & 6.8 & 37 & 13 & 72 & 30 & $14 \mathrm{~B}$ & $36 \mathrm{~B}$ & $33 \mathrm{~B}$ & $43 \mathrm{~B}$ & $22 \mathrm{~B}$ \\
\hline Bicarbonate Alkalinity as $\mathrm{CaCO} 3$ & 73 & 6.8 & 37 & 13 & 71 & 30 & $14 \mathrm{~B}$ & $36 \mathrm{~B}$ & $33 \mathrm{~B}$ & $35 \mathrm{~B}$ & $22 \mathrm{~B}$ \\
\hline Chemical Oxygen Demand & 56 & $<20$ & 69 & $<20$ & $<20$ & 34 & $<10$ & 12 & 43 & & \\
\hline Chloride & 13 & 5 & 5 & 5 & 7.2 & 18 & 4.1 & 43 & 48 & 23 & 4.8 \\
\hline Fluoride & $<1$ & $<1.0$ & $<1$ & $<1.0$ & $<1.0$ & $<1.0$ & $0.28 \mathrm{~B}$ & 0.087 & 0.15 & & \\
\hline Laboratory pH (S.U.) & 7.26 & 6.86 & 7.17 & 7.22 & 7.76 & 7.46 & $6.54 \mathrm{HF}$ & $7.08 \mathrm{HF}$ & $7.15 \mathrm{HF}$ & & \\
\hline Nitrate as $\mathrm{N}$ & 0.11 & 2.3 & 0.5 & 0.29 & 0.48 & 0.6 & $2.4 \mathrm{~B}$ & $<0.05$ & $<0.05$ & & \\
\hline Nitrate Nitrite Nitrogen & & & & & & & & $0.022 \mathrm{~J}$ & & & \\
\hline Specific Conductance (umhos/cm) & 310 & $<5.0$ & 180 & 160 & 260 & 270 & 160 & 340 & 350 & 280 & 170 \\
\hline Sulfate & 61 & 35 & 43 & 42 & 53 & 61 & 42 & 55 & 59 & 53 & 43 \\
\hline TDS & 100 & 80 & 110 & 110 & 160 & 190 & 110 & 190 & 210 & 170 & 95 \\
\hline Total Hardness & & & & & & & & & & & \\
\hline Total Organic Carbon & 1 & 1.2 & 3.8 & 1.8 & 4.1 & 2.4 & 1.1 & 2.1 & 1.8 & & \\
\hline Turbidity (NTU) & 510 & 2.8 & 15 & 8.1 & 4.1 & 4.0 & 5.7 & $0.39 \mathrm{~J}$ & $0.46 \mathrm{~J}$ & $0.66 \mathrm{~J}$ & 2.6 \\
\hline
\end{tabular}

Notes:

$<-$ Analyte was not detected above the indicated Laboratory Reporting Limit

$\mathrm{J}$ - The analyte was positively identified but the value is estimated as it is below the Laboratory Reporting Limit but above the Method Detection Limit

B - Compound was found in the blank and sample. 


\begin{tabular}{|c|c|c|c|c|c|c|c|c|c|c|c|}
\hline Date Sampled: & \begin{tabular}{|c|} 
Spring-1 \\
$2 / 21 / 2013$ \\
\end{tabular} & \begin{tabular}{|c|} 
Spring-1 \\
$4 / 25 / 2013$ \\
\end{tabular} & \begin{tabular}{|c|} 
Spring-1 \\
$5 / 23 / 2013$ \\
\end{tabular} & \begin{tabular}{|c|} 
Spring-1 \\
$6 / 27 / 2013$ \\
\end{tabular} & \begin{tabular}{|c|} 
Spring-1 \\
$7 / 22 / 2013$ \\
\end{tabular} & \begin{tabular}{|c|} 
Spring-1 \\
$8 / 21 / 2013$ \\
\end{tabular} & \begin{tabular}{|c|} 
Spring-1 \\
$8 / 28 / 2013$ \\
\end{tabular} & \begin{tabular}{|c|} 
Spring-1 \\
$9 / 26 / 2013$ \\
\end{tabular} & \begin{tabular}{|c|} 
Spring-1 \\
$10 / 15 / 2013$ \\
\end{tabular} & \begin{tabular}{|c|} 
Spring-1 \\
$10 / 24 / 2013$ \\
\end{tabular} & \begin{tabular}{|c|} 
Spring-1 \\
$11 / 21 / 2013$ \\
\end{tabular} \\
\hline \multicolumn{12}{|l|}{ Field Parameters } \\
\hline Flow (gpm) & 13 & 15 & 1.5 & 10 & 6 & 1 & & $<0.5$ & 0.5 & $<0.5$ & \\
\hline $\mathrm{pH}(\mathrm{S} . \mathrm{U})$. & 7.92 & 7.41 & 7.88 & 7.05 & 7.44 & 7.58 & 7.46 & 7.37 & 6.39 & 7.85 & 7.89 \\
\hline $\mathrm{ORP}(\mathrm{mV})$ & 209 & 192 & 157 & 114 & 115 & 79 & 29 & -76.4 & 169 & 53 & \\
\hline \multicolumn{12}{|l|}{ Dissolved Oxygen (mg/l) } \\
\hline Conductivity (umhos $/ \mathrm{cm}$ ) & 210 & 176 & 253.3 & 228.3 & 255 & 267.9 & 268.1 & 291 & 307 & 313.5 & 399.9 \\
\hline Temperature (C) & 2.1 & 11.2 & 17.6 & 18.3 & 21.5 & 18.9 & 21.2 & 18.6 & 12.9 & 8.8 & 8.9 \\
\hline \multicolumn{12}{|l|}{ Dissolved Metals (mg/l) } \\
\hline Aluminum & $<0.02$ & $<0.02$ & & & $<0.02$ & & & & $<0.02$ & & \\
\hline Antimony & $<0.03$ & $<0.03$ & & & $<0.03$ & & & & $<0.03$ & & \\
\hline Arsenic & $<0.005$ & $<0.005$ & & & $<0.005$ & & & & $<0.005$ & & \\
\hline Barium & 0.0314 & 0.0367 & & & 0.0428 & & & & 0.0565 & & \\
\hline Beryllium & $<0.005$ & $<0.005$ & & & $<0.005$ & & & & $<0.005$ & & \\
\hline Boron & $<0.2$ & $<0.2$ & & & $<0.2$ & & & & $<0.2$ & & \\
\hline Cadmium & $<0.0025$ & $<0.0025$ & & & $<0.0025$ & & & & $<0.0025$ & & \\
\hline Calcium & 15.6 & 17.2 & & & 18.9 & & & & 25.4 & & \\
\hline Chromium & $<0.01$ & $<0.01$ & & & $<0.01$ & & & & $<0.01$ & & \\
\hline Cobalt & $<0.005$ & $<0.005$ & & & $<0.005$ & & & & $<0.005$ & & \\
\hline Copper & 0.0103 & $<0.01$ & & & $<0.01$ & & & & $<0.01$ & & \\
\hline Cyanide & & & & & $<0.01$ & & & & $<0.01$ & & \\
\hline Iron & $<0.05$ & $<0.05$ & & & $<0.05$ & & & & $<0.05$ & & \\
\hline Lead & $<0.005$ & $<0.005$ & & & $<0.005$ & & & & $<0.005$ & & \\
\hline Magnesium & 7.51 & 7.63 & & & 9.17 & & & & 11.2 & & \\
\hline Manganese & 0.0177 & 0.0264 & & & 0.0504 & & & & 0.15 & & \\
\hline Mercury & $<0.0002$ & $<0.0002$ & & & $<0.0002$ & & & & $<0.0002$ & & \\
\hline Molybdenum & $<0.005$ & $<0.005$ & & & $<0.005$ & & & & $<0.005$ & & \\
\hline Nickel & $<0.02$ & $<0.02$ & & & $<0.02$ & & & & $<0.02$ & & \\
\hline Potassium & 1.03 & 1.1 & & & 1.35 & & & & 2.21 & & \\
\hline Selenium & $<0.005$ & $<0.005$ & & & $<0.005$ & & & & $<0.005$ & & \\
\hline Silver & $<0.005$ & $<0.005$ & & & $<0.005$ & & & & $<0.005$ & & \\
\hline Sodium & 6.98 & 6.12 & & & 9.5 & & & & 13.9 & & \\
\hline Thallium & $<0.0025$ & $<0.0025$ & & & $<0.0025$ & & & & $<0.0025$ & & \\
\hline Vanadium & $<0.005$ & $<0.005$ & & & $<0.005$ & & & & $<0.005$ & & \\
\hline Zinc & $<0.02$ & $<0.02$ & & & $<0.02$ & & & & $<0.02$ & & \\
\hline \multicolumn{12}{|l|}{ Total Metals (mg/l) } \\
\hline Aluminum & 0.0724 & 0.0571 & & & $<0.02$ & & & & $<0.02$ & & \\
\hline Antimony & $<0.03$ & $<0.03$ & & & $<0.03$ & & & & $<0.03$ & & \\
\hline Arsenic & $<0.005$ & $<0.005$ & & & $<0.005$ & & $0.0008 \mathrm{~J}$ & $0.00058 \mathrm{~J}$ & $<0.005$ & $0.00038 \mathrm{~J}$ & $<0.001$ \\
\hline Barium & 0.0323 & 0.0377 & & & 0.0437 & & & & 0.0585 & & \\
\hline Beryllium & $<0.005$ & $<0.005$ & & & $<0.005$ & & & & $<0.005$ & & \\
\hline Boron & $<0.2$ & $<0.2$ & & & $<0.2$ & & 0.05 & 0.057 & $<0.2$ & $0.034 \mathrm{~B}$ & $0.03 \mathrm{~B}$ \\
\hline Cadmium & $<0.0025$ & $<0.0025$ & & & $<0.0025$ & & & & $<0.0025$ & & \\
\hline Calcium & 15.3 & 17.3 & 23 & 18 & 19.2 & 30 & 29 & 29 & 25.8 & 25 & 25 \\
\hline Chromium & $<0.01$ & $<0.01$ & & & $<0.01$ & & & & $<0.01$ & & \\
\hline Cobalt & $<0.005$ & $<0.005$ & & & $<0.005$ & & & & $<0.005$ & & \\
\hline Copper & $<0.01$ & $<0.01$ & & & $<0.01$ & & & & $<0.01$ & & \\
\hline Cyanide & $<0.01$ & $<0.01$ & & & $<0.01$ & & & & $<0.01$ & & \\
\hline Iron & 0.182 & 0.149 & & & $<0.05$ & & $0.11 \mathrm{~B}$ & $0.073 \mathrm{~B}$ & 0.0927 & $0.081 \mathrm{~B}$ & 0.075 \\
\hline Lead & $<0.005$ & $<0.005$ & & & $<0.005$ & & & & $<0.005$ & & \\
\hline Magnesium & 7.49 & 7.65 & 9.9 & 7.5 & 9.27 & 13 & 12 & 10 & 11.4 & 11 & 12 \\
\hline Manganese & 0.0269 & 0.0335 & & & 0.0521 & & 0.021 & $0.057 \mathrm{~B}$ & 0.186 & $0.045 \mathrm{~B}$ & $0.04 \mathrm{~B}$ \\
\hline Mercury & $<0.0002$ & $<0.0002$ & & & $<0.0002$ & & & & $<0.0002$ & & \\
\hline Molybdenum & $<0.005$ & $<0.005$ & & & $<0.005$ & & & & $<0.005$ & & \\
\hline Nickel & $<0.02$ & $<0.02$ & & & $<0.02$ & & & & $<0.02$ & & \\
\hline Potassium & 1.02 & 1.07 & & & 1.36 & & $2.7 \mathrm{~B}$ & $2.9 \mathrm{~B}$ & 2.25 & 1.9 & 1.7 \\
\hline Selenium & $<0.005$ & $<0.005$ & & & $<0.005$ & & & & $<0.005$ & & \\
\hline Silver & $<0.005$ & $<0.005$ & & & $<0.005$ & & & & $<0.005$ & & \\
\hline Sodium & 7.08 & 5.93 & & & 9.59 & & 15 & $19^{\wedge}$ & 14.1 & $15 \mathrm{~B}$ & $16 \mathrm{~B}$ \\
\hline Thallium & $<0.0025$ & $<0.0025$ & & & $<0.0025$ & & & & $<0.0025$ & & \\
\hline Vanadium & $<0.001$ & $<0.001$ & & & $<0.001$ & & & & $<0.001$ & & \\
\hline Zinc & $<0.02$ & $<0.02$ & & & $<0.02$ & & & & $<0.02$ & & \\
\hline General Chemistry ( $\mathrm{mg} / \mathrm{l}$ unless otherwise noted) & & & & & & & & & & & \\
\hline Ammonia & $<0.2$ & $<0.2$ & & & $<0.2$ & & & & $<0.2$ & & \\
\hline Total Alkalinity & 23 & 21.5 & & & 31.5 & & $40 \mathrm{~B}$ & 50 & 38.8 & $38 \mathrm{~B}$ & $37 \mathrm{~B}$ \\
\hline Bicarbonate Alkalinity as $\mathrm{CaCO} 3$ & 23 & 21.5 & & & 31.5 & & $40 \mathrm{~B}$ & 50 & 38.8 & $38 \mathrm{~B}$ & $37 \mathrm{~B}$ \\
\hline Chemical Oxygen Demand & $<20$ & $<20$ & & & $<20$ & & & & $<20$ & & \\
\hline Chloride & 7.82 & 7.04 & 16 & 12 & 11.8 & 16 & 18 & 25 & 32.7 & 32 & 25 \\
\hline Fluoride & $<0.1$ & $<0.1$ & & & $<0.1$ & & & & $<0.1$ & & \\
\hline Laboratory pH (S.U.) & 6.68 & 6.63 & & & 7.03 & & & & 6.44 & & \\
\hline Nitrate as $\mathrm{N}$ & 1.25 & 1.22 & & & 0.527 & & & & $<0.022$ & & \\
\hline Nitrate Nitrite Nitrogen & & & & & & & & & & & \\
\hline Specific Conductance (umhos/cm) & 198 & 198 & & & 233 & & & & 321 & & \\
\hline Sulfate & 48.3 & 49.7 & 53 & 47 & 55.8 & 55 & 63 & 60 & 59.6 & 59 & 65 \\
\hline TDS & 104 & 156 & 150 & 120 & 184 & 140 & 140 & 150 & 196 & 170 & 160 \\
\hline Total Hardness & & & & & & & & & & & \\
\hline Total Organic Carbon & $<0.5$ & $<1$ & & & $<1$ & & & & 1.38 & & \\
\hline Turbidity (NTU) & 3.3 & 2.9 & & & $<1$ & & 4.3 & 3.1 & $<1$ & 3.2 & 2.4 \\
\hline
\end{tabular}

Notes:

$<-$ Analyte was not detected above the indicated Laboratory Reporting Limit

$\mathrm{J}$ - The analyte was positively identified but the value is estimated as it is below the Laboratory Reporting Limit but above the Method Detection Limit

B - Compound was found in the blank and sample. 


\begin{tabular}{|c|c|c|c|c|c|c|c|c|c|c|c|}
\hline Date Sampled: & \begin{tabular}{|c|} 
Spring-1 \\
$12 / 19 / 2013$ \\
\end{tabular} & \begin{tabular}{|c|} 
Spring-1 \\
$1 / 14 / 2014$ \\
\end{tabular} & \begin{tabular}{|c|} 
Spring-1 \\
$2 / 14 / 2014$ \\
\end{tabular} & \begin{tabular}{|c|} 
Spring-1 \\
$2 / 26 / 2014$ \\
\end{tabular} & \begin{tabular}{|c|} 
Spring-1 \\
$3 / 11 / 2014$ \\
\end{tabular} & \begin{tabular}{|c|} 
Spring-1 \\
$4 / 9 / 2014$ \\
\end{tabular} & \begin{tabular}{|l|} 
Spring-1 \\
$5 / 8 / 2014$
\end{tabular} & \begin{tabular}{|c|} 
Spring-1 \\
$4 / 21 / 2014$ \\
\end{tabular} & \begin{tabular}{|c|} 
Spring-1 \\
$6 / 4 / 2014$ \\
\end{tabular} & \begin{tabular}{|c|} 
Spring-1 \\
$7 / 2 / 2014$ \\
\end{tabular} & $\begin{array}{c}\text { Spring-1 } \\
8 / 1 / 2014\end{array}$ \\
\hline \multicolumn{12}{|l|}{ Field Parameters } \\
\hline Flow (gpm) & 5 & 20 & 1.5 & 10 & 8 & 15 & 7 & 20 & 1 & 4 & 4 \\
\hline pH (S.U.) & 7.27 & 7.29 & 6.78 & 7.91 & 7.66 & 6.45 & 7.26 & 6.68 & 7.05 & 7.5 & 7.31 \\
\hline $\mathrm{ORP}(\mathrm{mV})$ & 88 & -12.6 & 141 & 124 & 89 & 135.7 & 142 & 161 & 73.6 & 81 & 121.6 \\
\hline Dissolved Oxygen (mg/l) & & & & & & 7.4 & & & 0.98 & & \\
\hline Conductivity (umhos $/ \mathrm{cm}$ ) & 234.1 & 152 & 229.7 & 143 & 172.4 & 140 & 178.1 & 186 & 226 & 203.6 & 234 \\
\hline Temperature (C) & 6.2 & 6.28 & 3.5 & 6 & 9.4 & 9.37 & 18.5 & 10.8 & 19.1 & 20.2 & 21.32 \\
\hline \multicolumn{12}{|l|}{ Dissolved Metals (mg/l) } \\
\hline Aluminum & & & & $<0.02$ & & & & $<0.02$ & & & $0.0064 \mathrm{JB}$ \\
\hline Antimony & & & & $<0.03$ & & & & $<0.03$ & & & $<0.002$ \\
\hline Arsenic & & & & $<0.005$ & & & & $<0.005$ & & & $0.00067 \mathrm{~J}$ \\
\hline Barium & & & & 0.0324 & & & & 0.0326 & & & 0.038 \\
\hline Beryllium & & & & $<0.005$ & & & & $<0.005$ & & & $<0.001$ \\
\hline Boron & & & & $<0.2$ & & & & $<0.2$ & & & 0.034 \\
\hline Cadmium & & & & $<0.0025$ & & & & $<0.0025$ & & & $<0.001$ \\
\hline Calcium & & & & 14.4 & & & & 15.7 & & & $18 \mathrm{~B}$ \\
\hline Chromium & & & & $<0.01$ & & & & $<0.01$ & & & $0.00032 \mathrm{~J}$ \\
\hline Cobalt & & & & $<0.005$ & & & & 0.0466 & & & $0.000054 \mathrm{~J}$ \\
\hline Copper & & & & $<0.01$ & & & & $<0.01$ & & & $0.00053 \mathrm{~J}$ \\
\hline Cyanide & & & & $<0.01$ & & & & $<0.01$ & & & $<0.01$ \\
\hline Iron & & & & $<0.05$ & & & & 0.103 & & & $0.01 \mathrm{~J}$ \\
\hline Lead & & & & $<0.005$ & & & & $<0.005$ & & & $0.000089 \mathrm{~J}$ \\
\hline Magnesium & & & & 6.5 & & & & 7.39 & & & 8.5 \\
\hline Manganese & & & & 0.015 & & & & 0.0339 & & & 0.022 \\
\hline Mercury & & & & $<0.0002$ & & & & $<0.0002$ & & & $<0.0002$ \\
\hline Molybdenum & & & & $<0.005$ & & & & $<0.005$ & & & $0.0012 \mathrm{~J}$ \\
\hline Nickel & & & & $<0.02$ & & & & 0.0263 & & & $0.00031 \mathrm{JB}$ \\
\hline Potassium & & & & 1.06 & & & & 0.978 & & & \begin{tabular}{|l|}
1.5 \\
\end{tabular} \\
\hline Selenium & & & & $<0.005$ & & & & $<0.005$ & & & $<0.005$ \\
\hline Silver & & & & $<0.005$ & & & & $<0.005$ & & & $<0.001$ \\
\hline Sodium & & & & 4.69 & & & & 5.81 & & & $11 \mathrm{~B}$ \\
\hline Thallium & & & & $<0.0025$ & & & & $<0.0025$ & & & $0.000025 \mathrm{~J}$ \\
\hline Vanadium & & & & $<0.005$ & & & & $<0.005$ & & & $\begin{array}{l}<0.001 \\
\end{array}$ \\
\hline Zinc & & & & $<0.02$ & & & & $<0.02$ & & & $0.0068 \mathrm{~B}$ \\
\hline \multicolumn{12}{|l|}{ Total Metals (mg/l) } \\
\hline Aluminum & & & & 0.0901 & & & & 0.0413 & & & $0.1 \mathrm{~B}$ \\
\hline Antimony & & & & $<0.03$ & & & & $<0.03$ & & & $<0.002$ \\
\hline Arsenic & $0.00026 \mathrm{~J}$ & $<0.001$ & $0.00038 \mathrm{~J}$ & $<0.005$ & $0.00064 \mathrm{~J}$ & $0.00021 \mathrm{~J}$ & $0.00016 \mathrm{~J}$ & $<0.005$ & $0.00026 \mathrm{~J}$ & $<0.001$ & $<0.001$ \\
\hline Barium & & & & 0.0339 & & & & 0.0334 & & & 0.042 \\
\hline Beryllium & & & & $<0.005$ & & & & $<0.005$ & & & $<0.001$ \\
\hline Boron & 0.032 & 0.021 & 0.026 & $<0.2$ & $0.027 \mathrm{~B}$ & 0.033 & 0.024 & $<0.2$ & $0.028 \mathrm{~B}$ & 0.032 & 0.035 \\
\hline Cadmium & & & & $<0.0025$ & & & & $<0.0025$ & & & $<0.001$ \\
\hline Calcium & 24 & 12 & 23 & 14.7 & 23 & 19 & 16 & 15.7 & 15 & 16 & 19 \\
\hline Chromium & & & & $<0.01$ & & & & $<0.01$ & & & $0.00048 \mathrm{~J}$ \\
\hline Cobalt & & & & $<0.005$ & & & & 0.0439 & & & $0.00014 \mathrm{~J}$ \\
\hline Copper & & & & $<0.01$ & & & & $<0.01$ & & & $0.00041 \mathrm{~J}$ \\
\hline Cyanide & & & & $<0.01$ & & & & $<0.01$ & & & $<0.01$ \\
\hline Iron & 0.19 & 0.29 & $0.27 \mathrm{~B}$ & 0.116 & 0.67 & $0.54 \mathrm{~B}$ & 0.46 & 0.152 & 0.78 & 0.58 & 0.19 \\
\hline Lead & & & & $<0.005$ & & & & $<0.005$ & & & $0.00028 \mathrm{~J} \mathrm{~B}$ \\
\hline Magnesium & 11 & 5.2 & 9.4 & 6.56 & 6.3 & 9.7 & 7.6 & 7.47 & 6.9 & 7.8 & 9 \\
\hline Manganese & $0.042 \mathrm{~B}$ & $0.035 \mathrm{~B}$ & 0.033 & 0.0198 & $0.059 \mathrm{~B}$ & $0.048 \mathrm{~B}$ & 0.049 & 0.037 & 0.068 & 0.075 & 0.031 \\
\hline Mercury & $<0.0002$ & & & $<0.0002$ & & & & $<0.0002$ & & & $<0.0002$ \\
\hline Molybdenum & & & & $<0.005$ & & & & $<0.005$ & & & $0.00068 \mathrm{~J}$ \\
\hline Nickel & & & & $<0.02$ & & & & 0.025 & & & $0.00049 \mathrm{~J} \mathrm{~B}$ \\
\hline Potassium & 1.5 & 1 & $1.2 \mathrm{~B}$ & 1.08 & 1.7 & $1.4 \mathrm{~B}$ & $1.1 \mathrm{~B}$ & 1 & 1.3 & 1.3 & \begin{tabular}{|c|}
1.6 \\
\end{tabular} \\
\hline Selenium & & & & $<0.005$ & & & & $<0.005$ & & & $0.0012 \mathrm{~J} \mathrm{~B}$ \\
\hline Silver & & & & $<0.005$ & & & & $<0.005$ & & & $<0.001$ \\
\hline Sodium & $12 \mathrm{~B}$ & $3.8 \mathrm{~B}$ & 12 & 4.8 & 6.7 & $5.6 \mathrm{~B}$ & $5.7 \mathrm{~B}$ & 5.76 & 6.5 & 7.1 & $11 \mathrm{~B}$ \\
\hline Thallium & & & & $<0.0025$ & & & & $<0.0025$ & & & $<0.001$ \\
\hline Vanadium & & & & $<0.001$ & & & & $<0.001$ & & & $0.00025 \mathrm{~J}$ \\
\hline Zinc & & & & $<0.02$ & & & & $<0.02$ & & & $0.0049 \mathrm{JB}$ \\
\hline \multicolumn{12}{|l|}{ General Chemistry (mg/l unless otherwise noted) } \\
\hline Ammonia & & & & $<0.2$ & & & & $<0.2$ & & & 0.13 \\
\hline Total Alkalinity & $24 \mathrm{~B}$ & $15 \mathrm{~B}$ & $18 \mathrm{~B}$ & 15.4 & $18 \mathrm{~B}$ & $15 \mathrm{~B}$ & $23 \mathrm{~B}$ & 21.8 & $18 \mathrm{~B}$ & $28 \mathrm{~B}$ & $34 \mathrm{~B}$ \\
\hline Bicarbonate Alkalinity as $\mathrm{CaCO} 3$ & 24 & $15 \mathrm{~B}$ & $18 \mathrm{~B}$ & 15.4 & $18 \mathrm{~B}$ & $15 \mathrm{~B}$ & $23 \mathrm{~B}$ & 21.8 & $18 \mathrm{~B}$ & $28 \mathrm{~B}$ & $34 \mathrm{~B}$ \\
\hline Chemical Oxygen Demand & & & & 30.3 & & & & $<20$ & & & $6 \mathrm{~J}$ \\
\hline Chloride & 14 & 3.5 & 13 & 4.3 & 7.1 & 3.9 & 4.1 & 5.94 & 8.4 & 39 & 10 \\
\hline Fluoride & & & & $<0.1$ & & & & $<0.1$ & & & $0.036 \mathrm{~J}$ \\
\hline Laboratory pH (S.U.) & & & & 6.86 & & & & 6.69 & & & $7.46 \mathrm{HF}$ \\
\hline Nitrate as $\mathrm{N}$ & & & & 2.23 & & & & 1.65 & & & 0.62 \\
\hline Nitrate Nitrite Nitrogen & & & & & & & & & & & \\
\hline Specific Conductance (umhos/cm) & & & & 164.2 & & & & 217 & & & 240 \\
\hline Sulfate & 61 & 39 & 57 & 41.4 & 47 & 46 & 44 & 48.2 & 51 & 260 & 51 \\
\hline TDS & 130 & 94 & 130 & 96 & 83 & 110 & 110 & 112 & 79 & 130 & 130 \\
\hline Total Hardness & & & & & & & & & & & \\
\hline Total Organic Carbon & & & & $<1$ & & & & $<1$ & & & 1.3 \\
\hline Turbidity (NTU) & 1.5 & 7.8 & 2.5 & 3.3 & 19 & 7.8 & 7.2 & 2.3 & 3.7 & 14 & 11 \\
\hline
\end{tabular}

Notes:

$<-$ Analyte was not detected above the indicated Laboratory Reporting Limit

$\mathrm{J}$ - The analyte was positively identified but the value is estimated as it is below the Laboratory Reporting Limit but above the Method Detection Limit

B - Compound was found in the blank and sample. 


\begin{tabular}{|c|c|c|c|c|c|c|c|c|c|c|c|}
\hline & \begin{tabular}{|c|} 
Spring-1 \\
\end{tabular} & Spring-1 & Spring-1 & Spring-1 & Spring-1 & Spring-1 & Spring-1 & \begin{tabular}{|l|} 
Spring-1 \\
\end{tabular} & Spring-1 & Spring-1 & $\begin{array}{l}\text { Spring-1 } \\
6 / 1 / 2015\end{array}$ \\
\hline Date Sampled: & & & & $12 / 4 / 2014$ & $1 / 7 / 2015$ & & & $3 / 16 / 2015$ & & & \\
\hline \multicolumn{12}{|l|}{ Field Parameters } \\
\hline Flow (gpm) & 1.5 & $<0.5$ & $<0.5$ & 1 & 1.5 & 2 & 5 & 10 & 10 & 6 & 1.5 \\
\hline pH (S.U.) & 7.75 & 7.75 & 7.99 & 7.49 & 6.5 & 7.87 & 7.5 & 6.3 & 6.67 & 7.15 & 6.94 \\
\hline $\mathrm{ORP}(\mathrm{mV})$ & 41 & 15 & 65 & 63 & 232.6 & 73.1 & -102.2 & 163 & 79.7 & 31.6 & 83.1 \\
\hline \multicolumn{12}{|l|}{ Dissolved Oxygen $(\mathrm{mg} / \mathrm{l})$} \\
\hline Conductivity (umhos/cm) & 257.3 & 291.6 & 314.1 & 321 & 196 & 252 & 175 & 153.4 & 152 & 179 & 242 \\
\hline Temperature (C) & 23.4 & 19.4 & 10.6 & 10.55 & 5.68 & 5.46 & 6.89 & 9.8 & 15.04 & 16.71 & 14.85 \\
\hline \multicolumn{12}{|l|}{ Dissolved Metals (mg/l) } \\
\hline Aluminum & & $0.0081 \mathrm{~J}$ & & & $0.0069 \mathrm{~J}$ & & & $0.0156 \mathrm{~J}$ & $0.0089 \mathrm{~J}$ & & \\
\hline Antimony & & $<0.002$ & & & $<0.000175$ & & & $<0.000175$ & $<0.000175$ & & \\
\hline Arsenic & & $0.00034 \mathrm{~J}$ & & & $<0.00015$ & & & $<0.00015$ & $0.000617 \mathrm{~J}$ & & \\
\hline Barium & & 0.043 & & & 0.0334 & & & 0.0349 & \begin{tabular}{|l|}
0.0353 \\
\end{tabular} & & \\
\hline Beryllium & & $<0.001$ & & & $<0.00022$ & & & $<0.00022$ & $<0.00022$ & & \\
\hline Boron & & 0.034 & & & $0.0239 \mathrm{~J}$ & & & $0.0412 \mathrm{~J}$ & $0.142 \mathrm{~J}$ & & \\
\hline Cadmium & & $<0.001$ & & & $<0.000175$ & & & $<0.000175$ & $<0.000175$ & & \\
\hline Calcium & & 22 & & & \begin{tabular}{|l|}
16.7 \\
\end{tabular} & & & 13.1 & \begin{tabular}{|l|}
14.7 \\
\end{tabular} & & \\
\hline Chromium & & $0.00076 \mathrm{~J}$ & & & $0.0004 \mathrm{~J}$ & & & $<0.0004$ & $0.0009 \mathrm{~J}$ & & \\
\hline Cobalt & & $0.00011 \mathrm{~J}$ & & & $<0.0007$ & & & $<0.0007$ & $<0.0007$ & & \\
\hline Copper & & $0.00071 \mathrm{~J}$ & & & $<0.0012$ & & & $<0.0012$ & $<0.0012$ & & \\
\hline Cyanide & & $<0.01$ & & & $<0.01$ & & & $<0.01$ & $<0.01$ & & \\
\hline Iron & & $0.018 \mathrm{~J}$ & & & $0.0082 \mathrm{~J}$ & & & $0.0152 \mathrm{~J}$ & $0.0181 \mathrm{~J}$ & & \\
\hline Lead & & $<0.001$ & & & $<0.00052$ & & & $<0.00052$ & $<0.00052$ & & \\
\hline Magnesium & & 9.8 & & & 8.03 & & & 6.08 & 6.37 & & \\
\hline Manganese & & 0.051 & & & 0.0394 & & & $0.005 \mathrm{~J}$ & 0.0276 & & \\
\hline Mercury & & $<0.0002$ & & & $<0.00004$ & & & $0.00008 \mathrm{~J}$ & $<0.00004$ & & \\
\hline Molybdenum & & $<0.005$ & & & $<0.001$ & & & $<0.001$ & $0.0015 \mathrm{~J}$ & & \\
\hline Nickel & & $0.00084 \mathrm{~J}$ & & & $<0.0018$ & & & $<0.0018$ & $<0.0018$ & & \\
\hline Potassium & & 2.2 & & & 1.07 & & & 1.76 & 1.08 & & \\
\hline Selenium & & $<0.005$ & & & $0.000779 \mathrm{~J}$ & & & $<0.000535$ & $<0.000535$ & & \\
\hline Silver & & $<0.001$ & & & $<0.0012$ & & & $<0.0012$ & \begin{tabular}{|c|}
$<0.0012$ \\
\end{tabular} & & \\
\hline Sodium & & 12 & & & 8.6 & & & 4.16 & 4.44 & & \\
\hline Thallium & & $<0.001$ & & & $<0.000175$ & & & $<0.000175$ & $<0.000175$ & & \\
\hline Vanadium & & $0.00057 \mathrm{~J}$ & & & $<0.0006$ & & & \begin{tabular}{|l|}
$<0.0006$ \\
\end{tabular} & $\begin{array}{l}<0.0006 \\
\end{array}$ & & \\
\hline Zinc & & $0.0056 \mathrm{~B}$ & & & $0.0171 \mathrm{~J}$ & & & 0.0213 & $0.0062 \mathrm{~J}$ & & \\
\hline \multicolumn{12}{|l|}{ Total Metals (mg/l) } \\
\hline \begin{tabular}{|l|} 
Aluminum \\
\end{tabular} & & 0.097 & & & 0.115 & & & 0.123 & 0.212 & & \\
\hline Antimony & & $0.000088 \mathrm{~J}$ & & & $<0.000175$ & & & $<0.000175$ & $<0.000175$ & & \\
\hline Arsenic & $0.00067 \mathrm{~J}$ & $0.00041 \mathrm{~J}$ & 0.0015 & $0.00026 \mathrm{~J}$ & $0.000183 \mathrm{~J}$ & $<0.00015$ & $0.0012 \mathrm{~J}$ & $0.000222 \mathrm{~J}$ & \begin{tabular}{|l|}
$0.0004 \mathrm{~J}$ \\
\end{tabular} & $0.000294 \mathrm{~J}$ & $0.000362 \mathrm{~J}$ \\
\hline Barium & & \begin{tabular}{|l|}
0.044 \\
\end{tabular} & & & 0.0341 & & & \begin{tabular}{|l|}
0.0352 \\
\end{tabular} & 0.0393 & & \\
\hline Beryllium & & $<0.001$ & & & $<0.00022$ & & & $<0.00022$ & $<0.00022$ & & \\
\hline Boron & 0.036 & 0.036 & 0.029 & 0.027 & $0.0306 \mathrm{~J}$ & $0.0185 \mathrm{~J}$ & $0.0482 \mathrm{~J}$ & $0.0425 \mathrm{~J}$ & $0.16 \mathrm{~J}$ & $0.0628 \mathrm{~J}$ & $0.187 \mathrm{~J}$ \\
\hline Cadmium & & $<0.001$ & & & $<0.000175$ & & & $<0.000175$ & 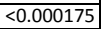 & & \\
\hline Calcium & 21 & 21 & 24 & 25 & 16.1 & 16.8 & $14.7 \mathrm{~B}$ & \begin{tabular}{|l|}
12.7 \\
\end{tabular} & \begin{tabular}{|l|}
14.3 \\
\end{tabular} & 17.1 & 22.1 \\
\hline Chromium & & $0.00046 \mathrm{~J}$ & & & $0.0004 \mathrm{~J}$ & & & $<0.0004$ & $0.0006 \mathrm{~J}$ & & \\
\hline Cobalt & & $0.00016 \mathrm{~J}$ & & & $<0.0007$ & & & $<0.0007$ & $<0.0007$ & & \\
\hline Copper & & $0.00057 \mathrm{~J}$ & & & $<0.0012$ & & & $<0.0012$ & $<0.0012$ & & \\
\hline Cyanide & & $<0.01$ & & & $<0.01$ & & & $<0.01$ & $<0.01$ & & \\
\hline Iron & $0.12 \mathrm{~B}$ & 0.16 & 3.2 & $0.049 \mathrm{~J}$ & 0.254 & 0.496 & 3.55 & 0.157 & \begin{tabular}{|l|}
0.395 \\
\end{tabular} & 0.282 & 0.106 \\
\hline Lead & & $0.00021 \mathrm{~J}$ & & & $<0.00052$ & & & $<0.00052$ & \begin{tabular}{|l|}
$0.000532 \mathrm{~J}$ \\
\end{tabular} & & \\
\hline Magnesium & $\begin{array}{l}7.8 \\
\end{array}$ & 9.9 & 10 & 9.5 & 7.81 & 7.72 & 6.89 & 5.93 & \begin{tabular}{|l|}
6.51 \\
\end{tabular} & 8.18 & 10.5 \\
\hline Manganese & 0.033 & 0.045 & $0.25 \mathrm{~B}$ & 0.12 & 0.0601 & 0.0912 & 0.372 & 0.0125 & 0.0508 & 0.0587 & 0.141 \\
\hline \begin{tabular}{|l|} 
Mercury \\
\end{tabular} & & 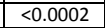 & & & $<0.00004$ & & & $0.0001 \mathrm{~J}$ & $<0.00004$ & & \\
\hline Molybdenum & & $0.00035 \mathrm{~J} \mathrm{~B}$ & & & $0.001 \mathrm{~J}$ & & & $0.0023 \mathrm{~J}$ & $0.001 \mathrm{~J}$ & & \\
\hline Nickel & & \begin{tabular}{|l|}
$0.0008 \mathrm{~J}$ \\
\end{tabular} & & & $<0.0018$ & & & $<0.0018$ & $<0.0018$ & & \\
\hline Potassium & 1.9 & 2.1 & 2.9 & 1.6 & 1.09 & 1.06 & 1.31 & 1.69 & 1.14 & 1.13 & 1.5 \\
\hline Selenium & & $<0.005$ & & & $<0.000535$ & & & $<<0.000535$ & $<0.000535$ & & \\
\hline \begin{tabular}{|l|} 
Silver \\
\end{tabular} & & $<0.001$ & & & $<0.0012$ & & & $<0.0012$ & \begin{tabular}{|c|}
$<0.0012$ \\
\end{tabular} & & \\
\hline Sodium & $11 \mathrm{~B}$ & 11 & 14 & 18 & 8.23 & 7.06 & 5.31 & 3.85 & 4.4 & 7.54 & $13.2 \mathrm{~B}$ \\
\hline Thallium & & $<0.001$ & & & $<0.000175$ & & & 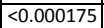 & 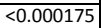 & & \\
\hline Vanadium & & $0.00044 \mathrm{~J}$ & & & $<0.0006$ & & & $<0.0006$ & \begin{tabular}{|c|}
$<0.0006$ \\
\end{tabular} & & \\
\hline Zinc & & 0.005 & & & $0.0176 \mathrm{~J}$ & & & $0.0136 \mathrm{~J}$ & $0.0085 \mathrm{~J}$ & & \\
\hline General Chemistry (mg/l unless otherwise noted) & & & & & & & & & & & \\
\hline Ammonia & & $<0.1$ & & & $<0.06$ & & & $<0.06$ & $<0.06$ & & \\
\hline Total Alkalinity & $46 \mathrm{~B}$ & $54 \mathrm{~B}$ & $45 \mathrm{~B}$ & $44 \mathrm{~B}$ & 23.6 & 20 & 16.2 & 10.4 & 15.8 & 24.6 & 34.3 \\
\hline Bicarbonate Alkalinity as $\mathrm{CaCO} 3$ & $46 \mathrm{~B}$ & $54 \mathrm{~B}$ & $45 \mathrm{~B}$ & $44 \mathrm{~B}$ & 23.6 & 20 & 16.2 & 10.4 & 15.8 & 24.6 & 34.3 \\
\hline Chemical Oxygen Demand & & $<10$ & & & $3.574 \mathrm{~J}$ & & & $3.574 \mathrm{~J}$ & $3.59 \mathrm{~J}$ & & \\
\hline Chloride & 14 & 23 & 28 & 35 & 8.36 & 5.94 & 4.52 & 2.78 & 3.36 & 8.56 & 16.9 \\
\hline Fluoride & & $0.064 \mathrm{~J} \mathrm{~B}$ & & & $<0.025$ & & & $<0.025$ & $0.047 \mathrm{~J}$ & & \\
\hline Laboratory pH (S.U.) & & $7.26 \mathrm{HF}$ & & & 7.87 & & & 6.55 & 6.96 & & \\
\hline Nitrate as $\mathrm{N}$ & & 0.12 & & & 1.81 & & & 4.23 & 2.19 & & \\
\hline Nitrate Nitrite Nitrogen & & & & & & & & & & & \\
\hline Specific Conductance (umhos/cm) & & 290 & & & 210.8 & & & 155.7 & 168.7 & & \\
\hline Sulfate & 57 & 59 & 57 & 74 & 50.3 & 44.8 & 39.1 & 35.4 & 39.7 & 51.2 & 60.1 \\
\hline TDS & 130 & 170 & 180 & 190 & 132 & 112 & 88 & 96 & 112 & 124 & 180 \\
\hline Total Hardness & & & & & & & & & & & \\
\hline Total Organic Carbon & & 2.5 & & & $0.767 \mathrm{~J}$ & & & 1.08 & 1.09 & & \\
\hline Turbidity (NTU) & 2.7 & 4.4 & 20 & $0.58 \mathrm{~J}$ & 3.97 & 10.1 & 23.9 & 4.17 & 6.43 & 6.54 & 2.28 \\
\hline
\end{tabular}

Notes:

<- Analyte was not detected above the indicated Laboratory Reporting Limit.

$\mathrm{J}$ - The analyte was positively identified but the value is estimated as it is belo

B - Compound was found in the blank and sample. 


\begin{tabular}{|c|c|c|c|c|c|c|c|c|c|c|c|}
\hline & Spring-2 & Spring-2 & Spring-2 & Spring-2 & Spring-2 & Spring-2 & Spring-2 & Spring-2 & \begin{tabular}{l|} 
Spring-2 \\
\end{tabular} & Spring-2 & Spring-2 \\
\hline Date Sampled: & $8 / 6 / 2009$ & $3 / 11 / 2010$ & $6 / 9 / 2010$ & $5 / 4 / 2011$ & $7 / 14 / 2011$ & $10 / 20 / 2011$ & $3 / 9 / 2012$ & $9 / 13 / 2012$ & 10/16/2012 & $11 / 14 / 2012$ & $1 / 17 / 2013$ \\
\hline \multicolumn{12}{|l|}{ Field Parameters } \\
\hline Flow (gpm) & & & & & & & & & 1 & 2 & 6 \\
\hline $\mathrm{pH}(\mathrm{S} . \mathrm{U})$. & 7.42 & 6.43 & 6.74 & & 7.69 & 6.93 & 7.56 & 7.12 & 6.72 & 6.59 & 6.99 \\
\hline $\mathrm{ORP}(\mathrm{mV})$ & 47 & 99 & 167 & & 19.8 & -4.9 & 158 & 62.4 & 53.5 & 73.3 & 42 \\
\hline Dissolved Oxygen (mg/l) & & & & & & & & 8.12 & 3.23 & 5.25 & 9.72 \\
\hline Conductivity (umhos/cm) & 317.2 & 154.8 & 173.3 & & 321 & 265 & 164.8 & 565 & 752 & 422 & 324 \\
\hline Temperature (C) & 17.6 & 3.5 & 16.1 & & 18.41 & 10.52 & 6.5 & 18.47 & 12.65 & 9.94 & 6.9 \\
\hline \multicolumn{12}{|l|}{ Dissolved Metals (mg/l) } \\
\hline \multicolumn{12}{|l|}{ Aluminum } \\
\hline \multicolumn{12}{|l|}{ Antimony } \\
\hline Arsenic & & & & & & & & 0.001 & $0.0014 \mathrm{~B}$ & & \\
\hline Barium & & & & & & & & $0.12 \mathrm{~B}$ & 0.13 & & \\
\hline Beryllium & & & & & & & & & & & \\
\hline Boron & & & & & & & & $0.13 \mathrm{~B} \wedge^{\wedge}$ & $0.058 \mathrm{~B}$ & & \\
\hline Cadmium & & & & & & & & $<0.001$ & $<0.001$ & & \\
\hline Calcium & & & & & & & & $53 \mathrm{~B}$ & 100 & & \\
\hline Chromium & & & & & & & & $0.00056 \mathrm{~J}$ & $0.00054 \mathrm{~J}$ & & \\
\hline Cobalt & & & & & & & & & & & \\
\hline Copper & & & & & & & & $0.00085 \mathrm{~J} \mathrm{~B}$ & $0.00072 \mathrm{~J}$ & & \\
\hline Cyanide & & & & & & & & & $<0.01$ & & \\
\hline Iron & & & & & & & & 0.17 & $0.34 \mathrm{~B}$ & & \\
\hline Lead & & & & & & & & $0.000021 \mathrm{~J} \mathrm{~B}$ & $<0.001$ & & \\
\hline Magnesium & & & & & & & & $18 \mathrm{~B}$ & $32 \mathrm{~B}$ & & \\
\hline Manganese & & & & & & & & $0.73 \mathrm{~B}$ & 0.3 & & \\
\hline Mercury & & & & & & & & $<0.0002$ & $<0.0002$ & & \\
\hline Molybdenum & & & & & & & & $0.0035 \mathrm{~J} \mathrm{~B}$ & $0.00028 \mathrm{~J} \mathrm{~B}$ & & \\
\hline Nickel & & & & & & & & & & & \\
\hline Potassium & & & & & & & & $2.8 \mathrm{~B}$ & $2.5 \mathrm{~B}$ & & \\
\hline Selenium & & & & & & & & $0.00093 \mathrm{~J}$ & $0.0034 \mathrm{JB}$ & & \\
\hline Silver & & & & & & & & $0.000049 \mathrm{~J}$ & $<0.001$ & & \\
\hline Sodium & & & & & & & & $10 \mathrm{~B}$ & $19 \mathrm{~B}$ & & \\
\hline Thallium & & & & & & & & $0.00025 \mathrm{JB}$ & $<0.001$ & & \\
\hline Vanadium & & & & & & & & & & & \\
\hline Zinc & & & & & & & & $0.0045 \mathrm{~J} \mathrm{~B}$ & 0.01 & & \\
\hline Total Metals (mg/l) & & & & & & & & & & & \\
\hline Aluminum & & & & & & & & & & & \\
\hline Antimony & & & & & & & & & & & \\
\hline Arsenic & 0.015 & $<0.0025$ & 0.0049 & $<0.0025$ & $<0.0025$ & $<0.0025$ & $0.00031 \mathrm{~J}$ & $0.0059 \mathrm{~B}$ & $0.0019 \mathrm{~B}$ & $0.00022 \mathrm{~J}$ & $<0.001$ \\
\hline Barium & & & & & & & & 0.27 & 0.14 & & \\
\hline Beryllium & & & & & & & & & & & \\
\hline Boron & $<0.1$ & $<0.1$ & $<0.1$ & $<0.1$ & $<0.1$ & $<0.1$ & 0.046 & $0.054 \mathrm{~B}$ & $0.064 \mathrm{~B}$ & $0.038 \mathrm{~B}$ & $0.057 \mathrm{~B}$ \\
\hline Cadmium & & & & & & & & $0.00033 \mathrm{~J}$ & $<0.001$ & & \\
\hline Calcium & 37 & 17 & 24 & 30 & 37 & 45 & 19 & 58 & 100 & 63 & 41 \\
\hline Chromium & & & & & & & & 0.0099 & $0.0008 \mathrm{~J}$ & & \\
\hline Cobalt & & & & & & & & & & & \\
\hline Copper & & & & & & & & 0.011 & $0.00099 \mathrm{~J}$ & & \\
\hline Cyanide & & & & & & & & & $<0.01$ & & \\
\hline Iron & 39 & $<0.1$ & 12 & 0.45 & 0.5 & 0.57 & $0.53 \mathrm{~B}$ & 22 & $0.83 \mathrm{~B}$ & 0.11 & $0.17 \mathrm{~B}$ \\
\hline Lead & & & & & & & & $0.014 \mathrm{~B}$ & $0.00043 \mathrm{~J}$ & & \\
\hline Magnesium & 15 & 6 & 8.7 & 9.6 & 14 & 15 & 6.7 & 20 & 32 & 20 & 15 \\
\hline Manganese & 3 & $<0.005$ & 0.33 & 0.054 & 0.06 & 0.31 & 0.015 & 2.1 & 0.36 & 0.098 & $0.028 \mathrm{~B}$ \\
\hline Mercury & $<0.0008$ & $<0.0008$ & $<0.0008$ & $<0.0008$ & $<0.0008$ & $<0.0008$ & $<0.0002$ & $0.000061 \mathrm{~J}$ & $<0.0002$ & $<0.0002$ & $<0.0002$ \\
\hline Molybdenum & & & & & & & & $0.0025 \mathrm{~J} \mathrm{~B}$ & $0.00018 \mathrm{~J} \mathrm{~B}$ & & \\
\hline Nickel & & & & & & & & & & & \\
\hline Potassium & 5.8 & 1.1 & 4.5 & 1.7 & 3.1 & 2.1 & $1.2 \mathrm{~B}$ & 3.3 & $2.5 \mathrm{~B}$ & 1.6 & $1.3 \mathrm{~B}$ \\
\hline Selenium & & & & & & & & $0.0022 \mathrm{JB}$ & $0.0054 \mathrm{~B}$ & & \\
\hline Silver & & & & & & & & $<0.001$ & $<0.001$ & & \\
\hline Sodium & 5.3 & 2.2 & 2.3 & 5.5 & 18 & 7.1 & $2.6 \mathrm{~B}$ & 9.2 & $19 \mathrm{~B}$ & $9.9 \mathrm{~B}$ & $8.1 \mathrm{~B}$ \\
\hline Thallium & & & & & & & & $0.00031 \mathrm{~J}$ & $<0.001$ & & \\
\hline Vanadium & & & & & & & & & & & \\
\hline Zinc & & & & & & & & 0.051 & 0.01 & & \\
\hline General Chemistry (mg/l unless otherwise noted) & & & & & & & & & & & \\
\hline Ammonia & 0.11 & $<0.05$ & $<0.05$ & 0.06 & 0.071 & 0.078 & $0.24 \mathrm{~B}$ & $0.27 \mathrm{~B}$ & $0.089 \mathrm{~J} \mathrm{~B}$ & & \\
\hline Total Alkalinity & 76 & 21 & 39 & 34 & 96 & 80 & $32 \mathrm{~B}$ & $76 \mathrm{~B}$ & $170 \mathrm{~B}$ & $150 \mathrm{~B}$ & $51 \mathrm{~B}$ \\
\hline Bicarbonate Alkalinity as $\mathrm{CaCO} 3$ & 75 & 21 & 39 & 33 & 95 & 79 & $32 \mathrm{~B}$ & $76 \mathrm{~B}$ & $170 \mathrm{~B}$ & $100 \mathrm{~B}$ & $51 \mathrm{~B}$ \\
\hline Chemical Oxygen Demand & 51 & $<20$ & 71 & 23 & $<20$ & 28 & $7.9 \mathrm{~J}$ & 20 & 48 & & \\
\hline Chloride & 14 & 0 & 0 & 0 & 16 & 16 & 2.1 & 41 & 62 & 30 & 13 \\
\hline Fluoride & $<1$ & $<1.0$ & $<1$ & $<1$ & $<1$ & $<1$ & $0.35 \mathrm{~B}$ & 0.064 & 0.31 & & \\
\hline Laboratory pH (S.U.) & 7.66 & 6.85 & 7.41 & 7.74 & 7.79 & 7.46 & $6.8 \mathrm{HF}$ & $7.05 \mathrm{HF}$ & $6.95 \mathrm{HF}$ & & \\
\hline Nitrate as $\mathrm{N}$ & 0.36 & 1.8 & 0.63 & 1.3 & 0.3 & 0.59 & $1.4 \mathrm{~B}$ & 0.16 & 0.12 & & \\
\hline Nitrate Nitrite Nitrogen & & & & & & & & 0.2 & & & \\
\hline Specific Conductance (umhos/cm) & 300 & 150 & 180 & 190 & 360 & 330 & 170 & 480 & 660 & 560 & 350 \\
\hline Sulfate & 54 & 36 & 38 & 43 & 62 & 70 & 38 & 98 & 220 & 150 & 110 \\
\hline TDS & 200 & 96 & 130 & 130 & 230 & 220 & 120 & 330 & 490 & 290 & 210 \\
\hline Total Hardness & & & & & & & & & & & \\
\hline Total Organic Carbon & 2.4 & 1.8 & 5.9 & 1.9 & 2.3 & 1.8 & 1.8 & 60 & 2.2 & & \\
\hline Turbidity (NTU) & 140 & 2 & 34 & 15 & 0.53 & 3.8 & 4.3 & 470 & 7.9 & 2.3 & 5.3 \\
\hline
\end{tabular}

Notes:

$<-$ Analyte was not detected above the indicated Laboratory Reporting Limit.

$\mathrm{J}$ - The analyte was positively identified but the value is estimated as it is below the Laboratory Reporting Limit but above the Method Detection Limit

B - Compound was found in the blank and sample. 


\begin{tabular}{|c|c|c|c|c|c|c|c|c|c|c|c|}
\hline Date Sampled: & \begin{tabular}{|c|} 
Spring-2 \\
$2 / 12 / 2013$ \\
\end{tabular} & \begin{tabular}{|c|} 
Spring-2 \\
$4 / 25 / 2013$ \\
\end{tabular} & \begin{tabular}{|c|} 
Spring-2 \\
$5 / 23 / 2013$ \\
\end{tabular} & \begin{tabular}{c|} 
Spring-2 \\
$6 / 27 / 2013$
\end{tabular} & \begin{tabular}{|c|} 
Spring-2 \\
$7 / 22 / 2013$ \\
\end{tabular} & \begin{tabular}{|c|} 
Spring-2 \\
$8 / 21 / 2013$
\end{tabular} & \begin{tabular}{|c|} 
Spring-2 \\
$8 / 28 / 2013$
\end{tabular} & \begin{tabular}{|c|} 
Spring-2 \\
$9 / 26 / 2013$ \\
\end{tabular} & \begin{tabular}{|c|} 
Spring-2 \\
$10 / 24 / 2013$ \\
\end{tabular} & \begin{tabular}{|c|} 
Spring-2 \\
$11 / 21 / 2013$
\end{tabular} & \begin{tabular}{|c|} 
Spring-2 \\
$10 / 10 / 2013$
\end{tabular} \\
\hline \multicolumn{12}{|l|}{ Field Parameters } \\
\hline Flow (gpm) & 11 & 2 & $<0.5$ & 10 & 3 & 1 & & $<0.5$ & $<0.5$ & & 0 \\
\hline $\mathrm{pH}(\mathrm{S} . \mathrm{U})$. & 9.08 & 6.86 & 6.84 & 6.38 & 6.91 & 6.53 & 7.11 & 7.34 & 7.81 & 7.7 & \\
\hline $\mathrm{ORP}(\mathrm{mV})$ & 139 & 202 & 173 & 123 & 91.8 & 124 & 104 & -80.2 & 80 & & \\
\hline \multicolumn{12}{|l|}{ Dissolved Oxygen (mg/l) } \\
\hline Conductivity (umhos/cm) & 404 & 732 & 468.7 & 458.3 & 507 & 567.1 & 564.1 & 677 & 735.8 & 749.1 & \\
\hline Temperature (C) & 4.9 & 9.8 & 15.3 & 17.6 & 21.1 & 18 & 20.9 & 16.5 & 9.9 & 9.1 & \\
\hline \multicolumn{12}{|l|}{ Dissolved Metals (mg/l) } \\
\hline Aluminum & $<0.02$ & $<0.02$ & & & $<0.02$ & & & & & & \\
\hline Antimony & $<0.03$ & $<0.03$ & & & $<0.03$ & & & & & & \\
\hline Arsenic & $<0.005$ & $<0.005$ & & & $<0.005$ & & & & & & \\
\hline Barium & 0.0539 & 0.0545 & & & 0.0826 & & & & & & \\
\hline Beryllium & $<0.005$ & $<0.005$ & & & $<0.005$ & & & & & & \\
\hline Boron & $<0.2$ & $<0.2$ & & & $<0.2$ & & & & & & \\
\hline Cadmium & $<0.0025$ & $<0.0025$ & & & $<0.0025$ & & & & & & \\
\hline Calcium & 44.1 & 38.6 & & & 58.9 & & & & & & \\
\hline Chromium & $<0.01$ & $<0.01$ & & & $<0.01$ & & & & & & \\
\hline Cobalt & $<0.005$ & $<0.005$ & & & $<0.005$ & & & & & & \\
\hline Copper & $<0.01$ & $<0.01$ & & & $<0.01$ & & & & & & \\
\hline Cyanide & & & & & $<0.01$ & & & & & & \\
\hline Iron & $<0.05$ & $<0.05$ & & & $<0.05$ & & & & & & \\
\hline Lead & $<0.005$ & $<0.005$ & & & $<0.005$ & & & & & & \\
\hline Magnesium & 15.5 & 13.2 & & & 20.4 & & & & & & \\
\hline Manganese & 0.0279 & 0.0315 & & & 0.221 & & & & & & \\
\hline Mercury & $<0.0002$ & $<0.0002$ & & & $<0.0002$ & & & & & & \\
\hline Molybdenum & $<0.005$ & $<0.005$ & & & $<0.005$ & & & & & & \\
\hline Nickel & $<0.02$ & $<0.02$ & & & $<0.02$ & & & & & & \\
\hline Potassium & 1.43 & 1.22 & & & 1.78 & & & & & & \\
\hline Selenium & $<0.005$ & $<0.005$ & & & $<0.005$ & & & & & & \\
\hline Silver & $<0.005$ & $<0.005$ & & & $<0.005$ & & & & & & \\
\hline Sodium & 9.42 & 8.01 & & & 13.3 & & & & & & \\
\hline Thallium & $<0.0025$ & $<0.0025$ & & & $<0.0025$ & & & & & & \\
\hline Vanadium & $<0.005$ & $<0.005$ & & & $<0.005$ & & & & & & \\
\hline Zinc & $<0.02$ & $<0.02$ & & & $<0.02$ & & & & & & \\
\hline \multicolumn{12}{|l|}{ Total Metals (mg/l) } \\
\hline Aluminum & 0.183 & 0.12 & & & 0.757 & & & & & & \\
\hline Antimony & $<0.03$ & $<0.03$ & & & $<0.03$ & & & & & & \\
\hline Arsenic & $<0.005$ & $<0.005$ & & & $<0.005$ & & $0.00047 \mathrm{~J}$ & $0.00052 \mathrm{~J}$ & $0.00057 \mathrm{~J}$ & $0.00064 \mathrm{~J}$ & \\
\hline Barium & 0.0553 & 0.0557 & & & 0.0921 & & & & & & \\
\hline Beryllium & $<0.005$ & $<0.005$ & & & $<0.005$ & & & & & & \\
\hline Boron & $<0.2$ & $<0.2$ & & & $<0.2$ & & 0.074 & 0.067 & $0.054 \mathrm{~B}$ & $0.049 \mathrm{~B}$ & \\
\hline Cadmium & $<0.0025$ & $<0.0025$ & & & $<0.0025$ & & & & & & \\
\hline Calcium & 44.5 & 38.6 & 55 & 51 & 57.9 & 74 & 84 & 100 & 85 & 100 & \\
\hline Chromium & $<0.01$ & $<0.01$ & & & $<0.01$ & & & & & & \\
\hline Cobalt & $<0.005$ & $<0.005$ & & & $<0.005$ & & & & & & \\
\hline Copper & $<0.01$ & $<0.01$ & & & $<0.01$ & & & & & & \\
\hline Cyanide & $<0.01$ & $<0.01$ & & & $<0.01$ & & & & & & \\
\hline Iron & 0.237 & 0.182 & & & 1.22 & & $0.18 \mathrm{~B}$ & $0.16 \mathrm{~B}$ & $0.35 \mathrm{~B}$ & 0.82 & \\
\hline Lead & $<0.005$ & $<0.005$ & & & $<0.005$ & & & & & & \\
\hline Magnesium & 15.7 & 13.3 & 17 & 17 & 20.1 & 23 & 26 & 32 & 28 & 38 & \\
\hline Manganese & 0.0372 & 0.0388 & & & 0.296 & & 0.33 & $0.21 \mathrm{~B}$ & $0.35 \mathrm{~B}$ & $0.49 \mathrm{~B}$ & \\
\hline Mercury & $<0.0002$ & $<0.0002$ & & & $<0.0002$ & & & & & & \\
\hline Molybdenum & $<0.005$ & $<0.005$ & & & $<0.005$ & & & & & & \\
\hline Nickel & $<0.02$ & $<0.02$ & & & $<0.02$ & & & & & & \\
\hline Potassium & 1.59 & 1.27 & & & 1.91 & & $3.1 \mathrm{~B}$ & $2.4 \mathrm{~B}$ & 2.2 & 2.3 & \\
\hline Selenium & $<0.005$ & $<0.005$ & & & $<0.005$ & & & & & & \\
\hline Silver & $<0.005$ & $<0.005$ & & & $<0.005$ & & & & & & \\
\hline Sodium & 10.4 & 8.11 & & & 13.5 & & 17 & $20^{\wedge}$ & $15 \mathrm{~B}$ & $18 \mathrm{~B}$ & \\
\hline Thallium & $<0.0025$ & $<0.0025$ & & & $<0.0025$ & & & & & & \\
\hline Vanadium & $<0.001$ & $<0.001$ & & & 0.0016 & & & & & & \\
\hline Zinc & $<0.02$ & $<0.02$ & & & $<0.02$ & & & & & & \\
\hline General Chemistry ( $\mathrm{mg} / \mathrm{l}$ unless otherwise noted) & & & & & & & & & & & \\
\hline Ammonia & $<0.2$ & $<0.2$ & & & $<0.2$ & & & & & & \\
\hline Total Alkalinity & 47.2 & 45.2 & & & 72.9 & & $86 \mathrm{~B}$ & 92 & $94 \mathrm{~B}$ & $85 \mathrm{~B}$ & \\
\hline Bicarbonate Alkalinity as $\mathrm{CaCO} 3$ & 47.2 & 45.2 & & & 72.9 & & $86 \mathrm{~B}$ & 92 & $94 \mathrm{~B}$ & $85 \mathrm{~B}$ & \\
\hline Chemical Oxygen Demand & $<20$ & $<20$ & & & 32.1 & & & & & & \\
\hline Chloride & 15.9 & 12.7 & 23 & 17 & 20.3 & 25 & 28 & 40 & 44 & 46 & \\
\hline Fluoride & 0.168 & 0.118 & & & 0.141 & & & & & & \\
\hline Laboratory pH (S.U.) & 6.61 & 6.11 & & & 6.63 & & & & & & \\
\hline Nitrate as $\mathrm{N}$ & 1.11 & 0.377 & & & 0.117 & & & & & & \\
\hline Nitrate Nitrite Nitrogen & & & & & & & & & & & \\
\hline Specific Conductance (umhos/cm) & 406 & 350 & & & 511 & & & & & & \\
\hline Sulfate & 134 & 97.6 & 130 & 120 & 141 & 140 & 160 & 190 & 230 & 270 & \\
\hline TDS & 276 & 240 & 240 & 280 & 348 & 310 & 290 & 370 & 520 & 470 & \\
\hline Total Hardness & & & & & & & & & & & \\
\hline Total Organic Carbon & 1.14 & 1.2 & & & 1.2 & & & & & & \\
\hline Turbidity (NTU) & 8 & 6 & & & 35 & & 14 & 8.6 & 12 & 12 & \\
\hline
\end{tabular}

Notes:

$<-$ Analyte was not detected above the indicated Laboratory Reporting Limit.

$\mathrm{J}$ - The analyte was positively identified but the value is estimated as it is below the Laboratory Reporting Limit but above the Method Detection Limit

B - Compound was found in the blank and sample. 


\begin{tabular}{|c|c|c|c|c|c|c|c|c|c|c|c|}
\hline & Spring-2 & \begin{tabular}{|l|} 
Spring-2 \\
\end{tabular} & \begin{tabular}{|l|} 
Spring-2 \\
\end{tabular} & \begin{tabular}{|l|} 
Spring-2 \\
\end{tabular} & \begin{tabular}{|l|} 
Spring-2 \\
\end{tabular} & Spring-2 & Spring-2 & Spring-2 & Spring-2 & Spring-2 & Spring-2 \\
\hline Date Sampled: & $12 / 19 / 2013$ & $1 / 14 / 2014$ & $2 / 14 / 2014$ & $2 / 26 / 2014$ & $3 / 11 / 2014$ & $4 / 9 / 2014$ & $4 / 21 / 2014$ & $5 / 8 / 2014$ & 6/4/2014 & $7 / 2 / 2014$ & $8 / 1 / 2014$ \\
\hline \multicolumn{12}{|l|}{ Field Parameters } \\
\hline Flow (gpm) & 2 & 20 & 1.5 & & 2 & 10 & 5 & 7 & 1 & 2.5 & 2.5 \\
\hline $\mathrm{pH}(\mathrm{S} . \mathrm{U})$. & 7.3 & 7.89 & 6.81 & 7.45 & 7.54 & 7.16 & 6.56 & 7.42 & 7.41 & 7.48 & 7.45 \\
\hline $\mathrm{ORP}(\mathrm{mV})$ & 111 & -57.3 & 157 & 74.3 & 75 & 70.7 & 57.3 & 178 & 5 & 60 & 61 \\
\hline Dissolved Oxygen (mg/l) & & & & & & 7.18 & & & 1.79 & & \\
\hline Conductivity (umhos/cm) & 779.5 & 338 & 579.3 & 589 & 567.1 & 383 & 595 & 418.6 & 449 & 551.4 & 664 \\
\hline Temperature $(\mathrm{C})$ & 5.9 & 5.56 & 3.9 & 3.8 & 7.2 & 12.16 & 12.6 & 17.7 & 17.59 & 19.1 & 18.49 \\
\hline \multicolumn{12}{|l|}{ Dissolved Metals (mg/l) } \\
\hline Antimony & & & & $<0.03$ & & & $<0.03$ & & & & $<0.002$ \\
\hline Arsenic & & & & $<0.005$ & & & $<0.005$ & & & & $0.00088 \mathrm{~J}$ \\
\hline Barium & & & & 0.0562 & & & 0.0469 & & & & 0.08 \\
\hline Beryllium & & & & $<0.005$ & & & $<0.005$ & & & & $<0.001$ \\
\hline Boron & & & & $<0.2$ & & & $<0.2$ & & & & 0.083 \\
\hline Cadmium & & & & $<0.0025$ & & & $<0.0025$ & & & & $<0.001$ \\
\hline Calcium & & & & 57 & & & 57.6 & & & & $76 \mathrm{~B}$ \\
\hline Chromium & & & & $<0.01$ & & & $<0.01$ & & & & $0.00033 \mathrm{~J}$ \\
\hline Cobalt & & & & $<0.005$ & & & 0.0441 & & & & $0.00012 \mathrm{~J}$ \\
\hline Copper & & & & $<0.01$ & & & $<0.01$ & & & & $0.00078 \mathrm{~J}$ \\
\hline Iron & & & & $<0.05$ & & & 0.0923 & & & & $0.015 \mathrm{~J}$ \\
\hline Lead & & & & $<0.005$ & & & $<0.005$ & & & & $<0.001$ \\
\hline Magnesium & & & & 27.7 & & & 28.7 & & & & 28 \\
\hline Manganese & & & & $<0.01$ & & & $<0.01$ & & & & 0.11 \\
\hline Mercury & & & & $<0.0002$ & & & $<0.0002$ & & & & $<0.0002$ \\
\hline Molybdenum & & & & $<0.005$ & & & $<0.005$ & & & & $0.00033 \mathrm{~J}$ \\
\hline Nickel & & & & $<0.02$ & & & 0.0261 & & & & $0.00085 \mathrm{~J} \mathrm{~B}$ \\
\hline Potassium & & & & 1.77 & & & 1.55 & & & & 1.9 \\
\hline Selenium & & & & $<0.005$ & & & $<0.005$ & & & & $0.00025 \mathrm{~J} \mathrm{~B}$ \\
\hline Silver & & & & $<0.005$ & & & $<0.005$ & & & & $<0.001$ \\
\hline Sodium & & & & 22.6 & & & 26 & & & & $22 \mathrm{~B}$ \\
\hline Thallium & & & & $<0.0025$ & & & $<0.0025$ & & & & $<0.001$ \\
\hline Vanadium & & & & $<0.005$ & & & $<0.005$ & & & & $<0.001$ \\
\hline Zinc & & & & $<0.02$ & & & $<0.02$ & & & & $0.0092 \mathrm{~B}$ \\
\hline \multicolumn{12}{|l|}{ Total Metals (mg/l) } \\
\hline Aluminum & & & & 0.103 & & & 0.335 & & & & $0.58 \mathrm{~B}$ \\
\hline Antimony & & & & $<0.03$ & & & $<0.03$ & & & & $<0.002$ \\
\hline Arsenic & $0.0007 \mathrm{~J}$ & $<0.001$ & $0.00039 \mathrm{~J}$ & $<0.005$ & $0.00089 \mathrm{~J}$ & $0.00028 \mathrm{~J}$ & $<0.005$ & $0.00017 \mathrm{~J}$ & $0.00037 \mathrm{~J}$ & $0.00056 \mathrm{~J} \mathrm{~B}$ & $0.00059 \mathrm{~J}$ \\
\hline Barium & & & & 0.0581 & & & 0.0505 & & & & 0.083 \\
\hline Calcium & 120 & 35 & 80 & 57.2 & 92 & 53 & 58 & 42 & 45 & 59 & 72 \\
\hline Chromium & & & & $<0.01$ & & & $<0.01$ & & & & $0.0011 \mathrm{~J}$ \\
\hline Cobalt & & & & $<0.005$ & & & 0.0471 & & & & $0.00047 \mathrm{~J}$ \\
\hline Copper & & & & $<0.01$ & & & $<0.01$ & & & & $0.001 \mathrm{~J}$ \\
\hline Cyanide & & & & $<0.01$ & & & $<0.01$ & & & & $0.002 \mathrm{~J}$ \\
\hline Iron & 0.68 & 0.16 & $0.23 \mathrm{~B}$ & 0.132 & 0.51 & $0.62 \mathrm{~B}$ & 0.632 & 0.52 & 1.4 & 1.7 & 0.88 \\
\hline Lead & & & & $<0.005$ & & & $<0.005$ & & & & $0.00076 \mathrm{~J} \mathrm{~B}$ \\
\hline Magnesium & 40 & 13 & 24 & 27.6 & 22 & 22 & 28.7 & 16 & 15 & 22 & 26 \\
\hline Manganese & $0.41 \mathrm{~B}$ & $0.034 \mathrm{~B}$ & 0.16 & $<0.01$ & $0.086 \mathrm{~B}$ & $0.054 \mathrm{~B}$ & 0.0306 & 0.066 & 0.15 & 0.17 & 0.14 \\
\hline Mercury & $<0.0002$ & & & $<0.0002$ & & & $<0.0002$ & & & & $<0.0002$ \\
\hline Molybdenum & & & & $<0.005$ & & & $<0.005$ & & & & $0.00029 \mathrm{~J}$ \\
\hline Nickel & & & & $<0.02$ & & & 0.0283 & & & & $0.0012 \mathrm{~B}$ \\
\hline Potassium & 2.4 & 1.3 & $1.6 \mathrm{~B}$ & 1.86 & 2 & $1.9 \mathrm{~B}$ & 1.6 & $1.4 \mathrm{~B}$ & 1.6 & 1.9 & 1.9 \\
\hline Selenium & & & & $<0.005$ & & & $<0.005$ & & & & $<0.005$ \\
\hline Silver & & & & $<0.005$ & & & $<0.005$ & & & & $<0.001$ \\
\hline Sodium & $23 \mathrm{~B}$ & $9 \mathrm{~B}$ & 17 & 22.5 & 17 & $17 \mathrm{~B}$ & 26 & $13 \mathrm{~B}$ & 12 & 16 & $20 \mathrm{~B}$ \\
\hline Thallium & & & & $<0.0025$ & & & $<0.0025$ & & & & $<0.001$ \\
\hline Vanadium & & & & $<0.001$ & & & $<0.001$ & & & & 0.0014 \\
\hline Zinc & & & & $<0.02$ & & & $<0.02$ & & & & $0.0092 \mathrm{~B}$ \\
\hline \multicolumn{12}{|l|}{ General Chemistry (mg/l unless otherwise noted) } \\
\hline Ammonia & & & & $<0.2$ & & & $<0.2$ & & & & $<0.1$ \\
\hline Total Alkalinity & $61 \mathrm{~B}$ & $42 \mathrm{~B}$ & $56 \mathrm{~B}$ & 46.9 & $48 \mathrm{~B}$ & $42 \mathrm{~B}$ & 61.3 & $55 \mathrm{~B}$ & $54 \mathrm{~B}$ & $69 \mathrm{~B}$ & $77 \mathrm{~B}$ \\
\hline Bicarbonate Alkalinity as $\mathrm{CaCO} 3$ & 61 & $42 \mathrm{~B}$ & $56 \mathrm{~B}$ & 46.9 & $48 \mathrm{~B}$ & $42 \mathrm{~B}$ & 61.3 & $55 \mathrm{~B}$ & $54 \mathrm{~B}$ & $69 \mathrm{~B}$ & $77 \mathrm{~B}$ \\
\hline Chemical Oxygen Demand & & & & $<20$ & & & $<20$ & & & & $<10$ \\
\hline Chloride & 43 & 10 & 29 & 23.7 & 26 & 12 & 23.1 & 12 & 18 & 24 & 29 \\
\hline Fluoride & & & & 0.126 & & & 0.103 & & & & 0.094 \\
\hline Laboratory pH (S.U.) & & & & 6.73 & & & 6.45 & & & & $7.58 \mathrm{HF}$ \\
\hline Nitrate as $\mathrm{N}$ & & & & 2.02 & & & 1.36 & & & & 0.31 \\
\hline Nitrate Nitrite Nitrogen & & & & & & & & & & & \\
\hline Specific Conductance (umhos/cm) & & & & 581.1 & & & 667 & & & & 690 \\
\hline Sulfate & 260 & 97 & 200 & 207 & 210 & 110 & 208 & 130 & 150 & 190 & 200 \\
\hline TDS & 470 & 220 & 360 & 384 & 360 & 210 & 416 & 280 & 230 & 360 & 420 \\
\hline Total Hardness & & & & & & & & & & & \\
\hline Total Organic Carbon & & & & 1.06 & & & 1.11 & & & & 1.7 \\
\hline Turbidity (NTU) & 11 & 19 & 8.2 & 3.8 & 19 & 4.8 & 13.7 & 23 & 3.3 & 21 & 31 \\
\hline
\end{tabular}

Notes:

$<-$ Analyte was not detected above the indicated Laboratory Reporting Limit.

$\mathrm{J}$ - The analyte was positively identified but the value is estimated as it is below the Laboratory Reporting Limit but above the Method Detection Limit

B - Compound was found in the blank and sample. 


\begin{tabular}{|c|c|c|c|c|c|c|c|c|c|c|c|}
\hline & Spring-2 & Spring-2 & Spring-2 & \begin{tabular}{|l|} 
Spring-2 \\
\end{tabular} & \begin{tabular}{|l|} 
Spring-2 \\
\end{tabular} & Spring-2 & \begin{tabular}{|l|} 
Spring-2 \\
\end{tabular} & \begin{tabular}{|l|} 
Spring-2 \\
\end{tabular} & Spring-2 & Spring-2 & Spring-2 \\
\hline Date Sampled: & $9 / 3 / 2014$ & $9 / 29 / 2014$ & $10 / 2 / 2014$ & $10 / 10 / 2014$ & $10 / 13 / 2014$ & $10 / 16 / 2014$ & $10 / 17 / 2014$ & $10 / 20 / 2014$ & $10 / 23 / 2014$ & $10 / 27 / 2014$ & $10 / 30 / 2014$ \\
\hline \multicolumn{12}{|l|}{ Field Parameters } \\
\hline Flow (gpm) & 1 & $<0.5$ & $<0.5$ & $<0.5$ & $<0.5$ & $<0.5$ & $<0.5$ & $<0.5$ & $<0.5$ & $<0.5$ & $<0.5$ \\
\hline pH (S.U.) & 8.2 & 7.64 & 8.22 & 8.38 & 8.19 & 8.11 & 7.14 & 8.04 & 8 & 6.85 & 7.29 \\
\hline $\mathrm{ORP}(\mathrm{mV})$ & 43 & 86 & 47 & 68 & 86 & 26 & 81 & 133 & 34 & 74 & 72 \\
\hline \multicolumn{12}{|l|}{ Dissolved Oxygen (mg/l) } \\
\hline Conductivity (umhos $/ \mathrm{cm}$ ) & 1251 & 1616 & 1623 & 1631 & 1664 & 1682 & 1909 & 1759 & 2075 & 2108 & 2124 \\
\hline Temperature (C) & 22 & 19.7 & 19 & 14.1 & 17.1 & 15.8 & 18.4 & 14.5 & 17.1 & 13 & 11.8 \\
\hline \multicolumn{12}{|l|}{ Dissolved Metals (mg/l) } \\
\hline Aluminum & & & $0.0065 \mathrm{~J}$ & & & & $0.0087 \mathrm{JB}$ & & & & \\
\hline Antimony & & & $<0.002$ & & & & $<0.002$ & & & & \\
\hline Arsenic & & & 0.0016 & & & & 0.0022 & & & & \\
\hline Barium & & & 0.11 & & & & 0.11 & & & & \\
\hline Beryllium & & & $<0.001$ & & & & $<0.001$ & & & & \\
\hline Boron & & & 0.17 & & & & 0.23 & & & & \\
\hline Cadmium & & & $0.000093 \mathrm{~J}$ & & & & $<0.001$ & & & & \\
\hline Calcium & & & 200 & & & & 230 & & & & \\
\hline Chromium & & & $0.0012 \mathrm{~J}$ & & & & $0.0016 \mathrm{~J}$ & & & & \\
\hline \begin{tabular}{|l|} 
Cobalt \\
\end{tabular} & & & $0.00025 \mathrm{~J}$ & & & & $0.00071 \mathrm{~B}$ & & & & \\
\hline Copper & & & $0.0014 \mathrm{~J}$ & & & & 0.0037 & & & & \\
\hline Cyanide & & & $<0.01$ & & & & $<0.01$ & & & & \\
\hline Iron & & & $0.032 \mathrm{~J}$ & & & & $0.015 \mathrm{~J}$ & & & & \\
\hline Lead & & & $<0.001$ & & & & $<0.001$ & & & & \\
\hline Magnesium & & & 77 & & & & $95 \mathrm{~B}$ & & & & \\
\hline Manganese & & & 0.027 & & & & $1.4 \mathrm{~B}$ & & & & \\
\hline Mercury & & & $<0.0002$ & & & & $<0.0002$ & & & & \\
\hline Molybdenum & & & $<0.005$ & & & & $0.0016 \mathrm{~J}$ & & & & \\
\hline Nickel & & & $0.00084 \mathrm{~J}$ & & & & 0.002 & & & & \\
\hline Potassium & & & 3.3 & & & & 3.8 & & & & \\
\hline Selenium & & & $0.00095 \mathrm{JB}$ & & & & $0.00022 \mathrm{~J}$ & & & & \\
\hline Silver & & & $<0.001$ & & & & $<0.001$ & & & & \\
\hline Sodium & & & 66 & & & & $95 \mathrm{~B}$ & & & & \\
\hline Thallium & & & $<0.001$ & & & & $<0.001$ & & & & \\
\hline Vanadium & & & 0.0013 & & & & $0.0006 \mathrm{~J}$ & & & & \\
\hline Zinc & & & $0.005 \mathrm{~B}$ & & & & 0.0068 & & & & \\
\hline \multicolumn{12}{|l|}{ Total Metals (mg/l) } \\
\hline Aluminum & & & \begin{tabular}{|l|}
0.051 \\
\end{tabular} & & & & $0.28 \mathrm{~B}$ & & & & \\
\hline Antimony & & & $0.00014 \mathrm{~J} \mathrm{~B}$ & & & & $<0.002$ & & & & \\
\hline Arsenic & 0.0032 & & $0.00058 \mathrm{~J}$ & & & & 0.0017 & & & & \\
\hline Barium & & & 0.1 & & & & 0.11 & & & & \\
\hline Beryllium & & & $<0.001$ & & & & $<0.001$ & & & & \\
\hline Boron & 0.16 & & 0.16 & & & & 0.24 & & & & \\
\hline Cadmium & & & $<0.001$ & & & & $0.00014 \mathrm{~J}$ & & & & \\
\hline Calcium & 160 & & 160 & & & & 220 & & & & \\
\hline Chromium & & & $0.00063 \mathrm{~J}$ & & & & 0.0036 & & & & \\
\hline Cobalt & & & $0.00026 \mathrm{~J}$ & & & & $0.001 \mathrm{~B}$ & & & & \\
\hline Copper & & & $0.0011 \mathrm{~J}$ & & & & 0.004 & & & & \\
\hline Cyanide & & & $<0.01$ & & & & $<0.01$ & & & & \\
\hline Iron & $0.045 \mathrm{~J} \mathrm{~B}$ & & 0.11 & & & & 0.71 & & & & \\
\hline Lead & & & $0.0001 \mathrm{~J}$ & & & & 0.0014 & & & & \\
\hline Magnesium & 51 & & 66 & & & & $89 \mathrm{~B}$ & & & & \\
\hline Manganese & 0.046 & & 0.039 & & & & $0.94 \mathrm{~B}$ & & & & \\
\hline Mercury & & & $<0.0002$ & & & & $<0.0002$ & & & & \\
\hline Molybdenum & & & $0.0016 \mathrm{~J} \mathrm{~B}$ & & & & $0.0022 \mathrm{~J}$ & & & & \\
\hline Nickel & & & $0.00068 \mathrm{~J}$ & & & & 0.0034 & & & & \\
\hline Potassium & 3 & & 2.8 & & & & 4.2 & & & & \\
\hline Selenium & & & $0.00035 \mathrm{~J}$ & & & & $0.00054 \mathrm{~J}$ & & & & \\
\hline Silver & & & $<0.001$ & & & & $<0.001$ & & & & \\
\hline Sodium & $49 \mathrm{~B}$ & & 56 & & & & $93 \mathrm{~B}$ & & & & \\
\hline Thallium & & & $<0.001$ & & & & $0.00011 \mathrm{~J}$ & & & & \\
\hline \begin{tabular}{|l} 
Vanadium \\
\end{tabular} & & & $0.00085 \mathrm{~J}$ & & & & 0.011 & & & & \\
\hline Zinc & & & $0.0038 \mathrm{~J}$ & & & & 0.016 & & & & \\
\hline General Chemistry (mg/l unless otherwise noted) & & & & & & & & & & & \\
\hline Ammonia & & & $<0.1$ & & & & $<0.1$ & & & & \\
\hline Total Alkalinity & $120 \mathrm{~B}$ & & $110 \mathrm{~B}$ & & & & $160 \mathrm{~B}$ & & & & \\
\hline Bicarbonate Alkalinity as $\mathrm{CaCO} 3$ & $120 \mathrm{~B}$ & & $110 \mathrm{~B}$ & & & & $160 \mathrm{~B}$ & & & & \\
\hline Chemical Oxygen Demand & & & $6.1 \mathrm{~J}$ & & & & $<10$ & & & & \\
\hline Chloride & 69 & 110 & 110 & 100 & 110 & 110 & 120 & 110 & 130 & 150 & 150 \\
\hline Fluoride & & & $0.14 \mathrm{~B}$ & & & & 0.19 & & & & \\
\hline Laboratory pH (S.U.) & & & $7.8 \mathrm{HF}$ & & & & $6.93 \mathrm{HF}$ & & & & \\
\hline Nitrate as $\mathrm{N}$ & & & 0.25 & & & & 0.29 & & & & \\
\hline Nitrate Nitrite Nitrogen & & & & & & & & & & & \\
\hline Specific Conductance (umhos/cm) & & & 1600 & & & & 1900 & & & & \\
\hline Sulfate & 480 & 730 & 660 & 670 & 680 & 730 & 790 & 710 & 850 & 1000 & 1100 \\
\hline TDS & 940 & & 1200 & & & & 1400 & & & & \\
\hline Total Hardness & & & & & & & & & & & \\
\hline Total Organic Carbon & & & 2.2 & & & & 2.5 & & & & \\
\hline Turbidity (NTU) & 1.1 & & 1.2 & & & & 12 & & & & \\
\hline
\end{tabular}

Notes:

$<-$ Analyte was not detected above the indicated Laboratory Reporting Limit.

$\mathrm{J}$ - The analyte was positively identified but the value is estimated as it is below the Laboratory Reporting Limit but above the Method De

B - Compound was found in the blank and sample. 


\begin{tabular}{|c|c|c|c|c|c|c|c|c|c|c|c|}
\hline & Spring-2 & \begin{tabular}{|l|} 
Spring-2 \\
\end{tabular} & \begin{tabular}{|l|} 
Spring-2 \\
\end{tabular} & Spring-2 & Spring-2 & \begin{tabular}{|l|} 
Spring-2 \\
\end{tabular} & \begin{tabular}{l|} 
Spring-2 \\
\end{tabular} & $\begin{array}{l}\text { Spring-2 } \\
\end{array}$ & Spring-2 & Spring-2 & Spring-2 \\
\hline Date Sampled: & $11 / 3 / 2014$ & $11 / 5 / 2014$ & $11 / 7 / 2014$ & $11 / 10 / 2014$ & $11 / 13 / 2014$ & $11 / 18 / 2014$ & $11 / 20 / 2014$ & \begin{tabular}{|l|}
$11 / 25 / 2014$ \\
\end{tabular} & $12 / 2 / 2014$ & \begin{tabular}{|l|}
$12 / 4 / 2014$ \\
\end{tabular} & $12 / 10 / 2014$ \\
\hline \multicolumn{12}{|c|}{ ( } \\
\hline Flow (gpm) & $<0.5$ & $<0.5$ & $<0.5$ & $<0.5$ & $<0.5$ & $<0.5$ & $<0.5$ & $<0.5$ & & $<0.5$ & $<0.5$ \\
\hline $\mathrm{pH}(\mathrm{S} . \mathrm{U})$. & 8.16 & 7.95 & 7.29 & 7.13 & 7.36 & 7.21 & 7.34 & 6.94 & 7.11 & 7.07 & 8.25 \\
\hline $\mathrm{ORP}(\mathrm{mV})$ & 109 & 47 & 124 & 80 & 87 & 131 & 140 & 120 & 134 & 124.7 & -54 \\
\hline \multicolumn{12}{|l|}{ Dissolved Oxygen (mg/l) } \\
\hline Conductivity (umhos/cm) & 1875 & 1896 & 2015 & 2107 & 2183 & 2030 & 2148 & 2121 & 2273 & 2094 & 1904 \\
\hline Temperature (C) & 8.4 & 10.9 & 9.3 & 13.6 & 9.4 & 6.4 & 6.3 & 10 & 8.4 & 9.66 & 6.8 \\
\hline \multicolumn{12}{|l|}{ Dissolved Metals (mg/l) } \\
\hline \multicolumn{12}{|l|}{ Aluminum } \\
\hline Antimony & & & & & & & & & & & \\
\hline Arsenic & & & & & & & & & & & \\
\hline Barium & & & & & & & & & & & \\
\hline Beryllium & & & & & & & & & & & \\
\hline Boron & & & & & & & & & & & \\
\hline Cadmium & & & & & & & & & & & \\
\hline Calcium & & & & & & & & & & & \\
\hline Chromium & & & & & & & & & & & \\
\hline Cobalt & & & & & & & & & & & \\
\hline Copper & & & & & & & & & & & \\
\hline Cyanide & & & & & & & & & & & \\
\hline Iron & & & 0.083 & 0.062 & $0.024 \mathrm{~J}$ & & & & & & \\
\hline Lead & & & & & & & & & & & \\
\hline Magnesium & & & & & & & & & & & \\
\hline Manganese & & & & & & & & & & & \\
\hline Mercury & & & & & & & & & & & \\
\hline Molybdenum & & & & & & & & & & & \\
\hline Nickel & & & & & & & & & & & \\
\hline Potassium & & & & & & & & & & & \\
\hline Selenium & & & & & & & & & & & \\
\hline Silver & & & & & & & & & & & \\
\hline Sodium & & & & & & & & & & & \\
\hline Thallium & & & & & & & & & & & \\
\hline Vanadium & & & & & & & & & & & \\
\hline Zinc & & & & & & & & & & & \\
\hline Total Metals (mg/l) & & & & & & & & & & & \\
\hline Aluminum & & & $0.37 \mathrm{~B}$ & $0.29 \mathrm{~B}$ & $0.013 \mathrm{~J}$ & & & & & & \\
\hline Antimony & & & $0.000055 \mathrm{~J}$ & $<0.002$ & $<0.002$ & & & & & & \\
\hline Arsenic & & 0.0013 & 0.0026 & 0.0024 & 0.0019 & & & & & 0.002 & \\
\hline Barium & & & 0.075 & 0.079 & 0.067 & & & & & & \\
\hline Beryllium & & & $<0.001$ & $<0.001$ & $<0.001$ & & & & & & \\
\hline Boron & & 0.14 & $0.21 \mathrm{~B}$ & $0.22 \mathrm{~B}$ & 0.18 & & & & & 0.23 & \\
\hline Cadmium & & & $<0.001$ & $<0.001$ & $0.00014 \mathrm{~J}$ & & & & & & \\
\hline Calcium & & 220 & 230 & 250 & 230 & & & & & 250 & \\
\hline Chromium & & & $0.0011 \mathrm{~J}$ & $0.00089 \mathrm{~J}$ & 0.003 & & & & & & \\
\hline Cobalt & & & 0.00065 & 0.0007 & $0.00041 \mathrm{~J}$ & & & & & & \\
\hline Copper & & & $0.0014 \mathrm{~J}$ & $0.0012 \mathrm{~J}$ & $0.0017 \mathrm{~J}$ & & & & & & \\
\hline Cyanide & & & & & & & & & & & \\
\hline Iron & & $0.04 \mathrm{~J}$ & 0.71 & 0.63 & $0.04 \mathrm{~J}$ & & & & & 0.11 & \\
\hline Lead & & & $0.00069 \mathrm{~J}$ & $0.00058 \mathrm{~J}$ & $0.000094 \mathrm{~J}$ & & & & & & \\
\hline Magnesium & & 82 & 95 & 100 & 81 & & & & & 100 & \\
\hline Manganese & & $0.019 \mathrm{~B}$ & $0.47 \mathrm{~B}$ & $0.78 \mathrm{~B}$ & 0.61 & & & & & 0.39 & \\
\hline Mercury & & & $<0.0002$ & $<0.0002$ & $<0.0002$ & & & & & & \\
\hline Molybdenum & & & $0.0013 \mathrm{~J}$ & $0.0012 \mathrm{~J}$ & $0.001 \mathrm{~J} \mathrm{~B}$ & & & & & & \\
\hline Nickel & & & 0.0017 & 0.0016 & 0.0021 & & & & & & \\
\hline Potassium & & 3.1 & & & & & & & & 3 & \\
\hline Selenium & & & $0.0012 \mathrm{~J}$ & $0.00088 \mathrm{~J}$ & $<0.005$ & & & & & & \\
\hline Silver & & & $<0.001$ & $<0.001$ & $<0.001$ & & & & & & \\
\hline Sodium & & 76 & & & & & & & & 110 & \\
\hline Thallium & & & $0.000019 \mathrm{~J}$ & $0.000016 \mathrm{~J}$ & $0.000015 \mathrm{~J}$ & & & & & & \\
\hline Vanadium & & & & & & & & & & & \\
\hline Zinc & & & $0.019 \mathrm{~B}$ & $0.014 \mathrm{~B}$ & 0.011 & & & & & & \\
\hline General Chemistry (mg/l unless otherwise noted) & & & & & & & & & & & \\
\hline Ammonia & & & 0.1 & $0.089 \mathrm{~J}$ & $0.092 \mathrm{~J}$ & & & & & & \\
\hline Total Alkalinity & & $110 \mathrm{~B}$ & & & & & & & & $150 \mathrm{~B}$ & \\
\hline Bicarbonate Alkalinity as $\mathrm{CaCO} 3$ & & $110 \mathrm{~B}$ & & & & & & & & $150 \mathrm{~B}$ & \\
\hline Chemical Oxygen Demand & & & 72 & 57 & $7.4 \mathrm{~J}$ & & & & & & \\
\hline Chloride & 120 & 310 & & & & 140 & 140 & 140 & 150 & 160 & 120 \\
\hline Fluoride & & & $0.3 \mathrm{~B}$ & 0.15 & 0.15 & & & & & & \\
\hline Laboratory pH (S.U.) & & & $6.92 \mathrm{HF}$ & $7.11 \mathrm{HF}$ & $6.93 \mathrm{HF}$ & & & & & & \\
\hline Nitrate as $\mathrm{N}$ & & & & & & & & & & & \\
\hline Nitrate Nitrite Nitrogen & & & $0.45 \mathrm{~B}$ & $0.29 \mathrm{~B}$ & $0.24 \mathrm{~B}$ & & & & & & \\
\hline Specific Conductance (umhos/cm) & & & & & & & & & & & \\
\hline Sulfate & 750 & 1900 & 790 & 960 & 1100 & 900 & 960 & 910 & 990 & 1000 & 790 \\
\hline TDS & & 1500 & 1300 & 1500 & 1600 & & & & & 1800 & \\
\hline Total Hardness & & & 970 & 1100 & 910 & & & & & & \\
\hline Total Organic Carbon & & & 2.6 & 1.6 & 1.5 & & & & & & \\
\hline Turbidity (NTU) & & 1.3 & $30 \mathrm{H}$ & 8.1 & $0.5 \mathrm{~J}$ & & & & & $0.34 \mathrm{~J}$ & \\
\hline
\end{tabular}

Notes:

$<-$ Analyte was not detected above the indicated Laborat

$\mathrm{J}$ - The analyte was positively identified but the value is es

B - Compound was found in the blank and sample. 
Table A-2 (Page 6 of 8)

Spring-2

\begin{tabular}{|c|c|c|c|c|c|c|c|c|c|c|c|}
\hline & \begin{tabular}{|l|} 
Spring-2 \\
\end{tabular} & Spring-2 & Spring-2 & Spring-2 & Spring-2 & Spring-2 & Spring-2 & Spring-2 & Spring-2 & \begin{tabular}{l|} 
Spring-2 \\
\end{tabular} & Spring-2 \\
\hline Date Sampled: & $12 / 17 / 2014$ & $12 / 22 / 2014$ & $1 / 2 / 2015$ & $1 / 7 / 2015$ & $1 / 16 / 2015$ & $1 / 19 / 2015$ & $1 / 27 / 2015$ & $2 / 2 / 2015$ & $2 / 13 / 2015$ & $2 / 17 / 2015$ & $2 / 25 / 2015$ \\
\hline \multicolumn{12}{|l|}{ Field Parameters } \\
\hline Flow (gpm) & $<0.5$ & $<0.5$ & $<0.5$ & $<0.5$ & $<0.5$ & $<0.5$ & $<0.5$ & 1 & $<0.5$ & 1 & $<0.5$ \\
\hline pH (S.U.) & 7.28 & 7.46 & 7.17 & 6.77 & 7.45 & 7.45 & 6.98 & 7.15 & 6.91 & 6.9 & 7.28 \\
\hline ORP (mV) & 124.6 & 148 & 168 & 140 & -23 & 120 & 299 & 212 & 311.2 & 177 & 159 \\
\hline \multicolumn{12}{|l|}{ Dissolved Oxygen (mg/l) } \\
\hline Conductivity (umhos/cm) & 2240 & 2087 & 1992 & 1481 & 1932 & 1970 & 1886 & 1115 & 1227 & 1254 & 1530 \\
\hline Temperature (C) & 6.71 & 9.8 & 7.5 & 5.14 & 6.1 & 5.4 & 5.8 & 5.1 & 4.91 & 5.2 & 4 \\
\hline \multicolumn{12}{|l|}{ Dissolved Metals (mg/l) } \\
\hline Antimony & & & & $<0.000175$ & & & & & & & \\
\hline Arsenic & & & & $\begin{array}{l}<0.00015 \\
\end{array}$ & & & & & & & \\
\hline Barium & & & & 0.0451 & & & & & & & \\
\hline Beryllium & & & & $<0.00022$ & & & & & & & \\
\hline Boron & & & & 0.249 & & & & & & & \\
\hline Cadmium & & & & \begin{tabular}{|l|}
$<0.000175$ \\
\end{tabular} & & & & & & & \\
\hline Calcium & & & & \begin{tabular}{|l|}
136 \\
\end{tabular} & & & & & & & \\
\hline Chromium & & & & $<0.0004$ & & & & & & & \\
\hline Cobalt & & & & $<0.0007$ & & & & & & & \\
\hline Copper & & & & $<0.0012$ & & & & & & & \\
\hline Iron & & & & $<0.0015$ & & & & & & & \\
\hline Lead & & & & $<0.00052$ & & & & & & & \\
\hline Magnesium & & & & 68.4 & & & & & & & \\
\hline Manganese & & & & 0.0181 & & & & & & & \\
\hline Mercury & & & & $<0.00004$ & & & & & & & \\
\hline Molybdenum & & & & $0.0036 \mathrm{~J}$ & & & & & & & \\
\hline Nickel & & & & $<0.0018$ & & & & & & & \\
\hline Potassium & & & & 2.45 & & & & & & & \\
\hline Selenium & & & & $<0.000535$ & & & & & & & \\
\hline Silver & & & & $<0.0012$ & & & & & & & \\
\hline Sodium & & & & 88.9 & & & & & & & \\
\hline Thallium & & & & \begin{tabular}{|l|}
$<0.000175$ \\
\end{tabular} & & & & & & & \\
\hline Vanadium & & & & \begin{tabular}{|l|}
$<0.0006$ \\
\end{tabular} & & & & & & & \\
\hline Zinc & & & & 0.04 & & & & & & & \\
\hline \multicolumn{12}{|l|}{ Total Metals (mg/l) } \\
\hline Aluminum & & & & 0.14 & & & & & & & \\
\hline Antimony & & & & \begin{tabular}{|c|}
$<0.000175$ \\
\end{tabular} & & & & & & & \\
\hline Arsenic & & & & $<0.0003$ & & & & & $0.000317 \mathrm{~J}$ & & \\
\hline Barium & & & & 0.0461 & & & & & & & \\
\hline Calcium & & & & 134 & & & & & 97.8 & & \\
\hline Chromium & & & & $<0.0004$ & & & & & & & \\
\hline Cobalt & & & & $<0.0007$ & & & & & & & \\
\hline Copper & & & & $<0.0012$ & & & & & & & \\
\hline Cyanide & & & & $<0.01$ & & & & & & & \\
\hline Iron & & & & 0.211 & & & & & 0.103 & & \\
\hline Lead & & & & $<0.00104$ & & & & & & & \\
\hline Magnesium & & & & 67.8 & & & & & 51.2 & & \\
\hline Manganese & & & & 0.0297 & & & & & $0.0092 \mathrm{~J}$ & & \\
\hline Mercury & & & & $<0.00004$ & & & & & & & \\
\hline Molybdenum & & & & $0.0037 \mathrm{~J}$ & & & & & & & \\
\hline Nickel & & & & $<0.0018$ & & & & & & & \\
\hline Potassium & & & & 2.49 & & & & & 2.1 & & \\
\hline Selenium & & & & $0.0029 \mathrm{~J}$ & & & & & & & \\
\hline Silver & & & & $<0.0012$ & & & & & & & \\
\hline Sodium & & & & 88.4 & & & & & 66.9 & & \\
\hline Thallium & & & & $<0.00035$ & & & & & & & \\
\hline Vanadium & & & & $<0.0006$ & & & & & & & \\
\hline Zinc & & & & 0.0396 & & & & & & & \\
\hline General Chemistry (mg/l unless otherwise noted) & & & & & & & & & & & \\
\hline Ammonia & & & & $<0.06$ & & & & & & & \\
\hline Total Alkalinity & & & & 98.5 & & & & & 66 & & \\
\hline Bicarbonate Alkalinity as $\mathrm{CaCO} 3$ & & & & 98.5 & & & & & 66 & & \\
\hline Chemical Oxygen Demand & & & & $<3$ & & & & & & & \\
\hline Chloride & 130 & 140 & 140 & 82.1 & 113 & 120 & 116 & 53.7 & 51.5 & 67.6 & 84.4 \\
\hline Fluoride & & & & $0.071 \mathrm{~J}$ & & & & & & & \\
\hline Laboratory pH (S.U.) & & & & 7.67 & & & & & & & \\
\hline Nitrate as $\mathrm{N}$ & & & & 1.11 & & & & & & & \\
\hline Nitrate Nitrite Nitrogen & & & & & & & & & & & \\
\hline Specific Conductance (umhos/cm) & & & & 1473 & & & & & & & \\
\hline Sulfate & 820 & 970 & 790 & 563 & 767 & 805 & 771 & 394 & 375 & 481 & 589 \\
\hline TDS & & & & 1080 & & & & & 720 & & \\
\hline Total Hardness & & & & & & & & & & & \\
\hline Total Organic Carbon & & & & 1.27 & & & & & & & \\
\hline Turbidity (NTU) & & & & 3.09 & & & & & 1.82 & & \\
\hline
\end{tabular}

Notes:

$<-$ Analyte was not detected above the indicated Laborat

$\mathrm{J}$ - The analyte was positively identified but the value is es

B - Compound was found in the blank and sample. 


\begin{tabular}{|c|c|c|c|c|c|c|c|c|c|c|c|}
\hline Date Sampled: & \begin{tabular}{|c|} 
Spring-2 \\
$3 / 4 / 2015$ \\
\end{tabular} & \begin{tabular}{|c|} 
Spring-2 \\
$3 / 10 / 2015$ \\
\end{tabular} & \begin{tabular}{|c|} 
Spring-2 \\
$3 / 18 / 2015$ \\
\end{tabular} & $\begin{array}{c}\text { Spring-2 } \\
3 / 24 / 2015\end{array}$ & \begin{tabular}{|c|} 
Spring-2 \\
$3 / 30 / 2015$ \\
\end{tabular} & $\begin{array}{l}\text { Spring-2 } \\
4 / 8 / 2015\end{array}$ & \begin{tabular}{|c|} 
Spring-2 \\
$4 / 13 / 2015$
\end{tabular} & \begin{tabular}{|c|} 
Spring-2 \\
$4 / 20 / 2015$ \\
\end{tabular} & \begin{tabular}{|c|} 
Spring-2 \\
$4 / 27 / 2015$ \\
\end{tabular} & \begin{tabular}{|l|} 
Spring-2 \\
$5 / 5 / 2015$
\end{tabular} & \begin{tabular}{|c|} 
Spring-2 \\
$5 / 12 / 2015$ \\
\end{tabular} \\
\hline \multicolumn{12}{|l|}{ Field Parameters } \\
\hline Flow (gpm) & 2 & 1 & 2 & $<0.5$ & $<0.5$ & 1 & $<0.5$ & $<0.5$ & 1 & $<0.5$ & $<0.5$ \\
\hline pH (S.U.) & 7.06 & 7.21 & 7.32 & 6.7 & 6.5 & 7.31 & 6.33 & 7.14 & 6.94 & 7.05 & 7.68 \\
\hline ORP $(\mathrm{mV})$ & 165 & -102.4 & 31 & 30 & 113 & -45.2 & 80 & 13.5 & 35.5 & 78.6 & 16 \\
\hline \multicolumn{12}{|l|}{ Dissolved Oxygen (mg/l) } \\
\hline Conductivity (umhos/cm) & 542.5 & 656 & 583.1 & 876.4 & 826.4 & 611 & 506.9 & 668 & 677 & 814 & 1040 \\
\hline Temperature (C) & 5.4 & 7.94 & 6.1 & 2.4 & 6.3 & 11.27 & 12 & 14.12 & 12.6 & 14.11 & 16.1 \\
\hline \multicolumn{12}{|l|}{ Dissolved Metals (mg/l) } \\
\hline Aluminum & & & & & & $0.0142 \mathrm{~J}$ & & & & & \\
\hline Antimony & & & & & & $<0.000175$ & & & & & \\
\hline \begin{tabular}{|l|} 
Arsenic \\
\end{tabular} & & & & & & $<0.00015$ & & & & & \\
\hline Barium & & & & & & 0.0423 & & & & & \\
\hline Beryllium & & & & & & $<0.00022$ & & & & & \\
\hline Boron & & & & & & 0.542 & & & & & \\
\hline Cadmium & & & & & & \begin{tabular}{|l|}
$<0.000175$ \\
\end{tabular} & & & & & \\
\hline Calcium & & & & & & 52.7 & & & & & \\
\hline Chromium & & & & & & $0.0012 \mathrm{~J}$ & & & & & \\
\hline Cobalt & & & & & & $0.0007 \mathrm{~J}$ & & & & & \\
\hline Copper & & & & & & $<0.0012$ & & & & & \\
\hline Cyanide & & & & & & $<0.01$ & & & & & \\
\hline \begin{tabular}{|l|l|} 
Iron \\
\end{tabular} & & & & & & $0.0114 \mathrm{~J}$ & & & & & \\
\hline Lead & & & & & & $<0.00052$ & & & & & \\
\hline Magnesium & & & & & & 25.4 & & & & & \\
\hline Manganese & & & & & & $0.0033 \mathrm{~J}$ & & & & & \\
\hline Mercury & & & & & & $<0.00004$ & & & & & \\
\hline Molybdenum & & & & & & $<0.001$ & & & & & \\
\hline Nickel & & & & & & $<0.0018$ & & & & & \\
\hline Potassium & & & & & & 1.83 & & & & & \\
\hline Selenium & & & & & & $<0.000535$ & & & & & \\
\hline \begin{tabular}{|l|} 
Silver \\
\end{tabular} & & & & & & $<0.0012$ & & & & & \\
\hline Sodium & & & & & & 34.2 & & & & & \\
\hline Thallium & & & & & & $<0.000175$ & & & & & \\
\hline Vanadium & & & & & & $<0.0006$ & & & & & \\
\hline Zinc & & & & & & 0.0248 & & & & & \\
\hline \multicolumn{12}{|l|}{ Total Metals (mg/l) } \\
\hline Aluminum & & & & & & 0.117 & & & & & \\
\hline Antimony & & & & & & $<0.000175$ & & & & & \\
\hline Arsenic & & $0.00031 \mathrm{~J}$ & & & & $0.000187 \mathrm{~J}$ & & & & $0.000196 \mathrm{~J}$ & \\
\hline Barium & & & & & & 0.0439 & & & & & \\
\hline Beryllium & & & & & & $<0.00022$ & & & & & \\
\hline Boron & & $0.142 \mathrm{~J}$ & & & & 0.606 & & & & 0.231 & \\
\hline Cadmium & & & & & & $<0.000175$ & & & & & \\
\hline Calcium & & 56.8 & & & & 53.2 & & & & 77.3 & \\
\hline Chromium & & & & & & $0.0004 \mathrm{~J}$ & & & & & \\
\hline Cobalt & & & & & & $<0.0007$ & & & & & \\
\hline Copper & & & & & & $<0.0012$ & & & & & \\
\hline Cyanide & & & & & & $<0.01$ & & & & & \\
\hline Iron & & 0.322 & & & & 0.119 & & & & 0.0693 & \\
\hline Lead & & & & & & $<0.00052$ & & & & & \\
\hline Magnesium & & 26.6 & & & & 25.8 & & & & 40.9 & \\
\hline Manganese & & 0.0136 & & & & $0.0077 \mathrm{~J}$ & & & & 0.0139 & \\
\hline Mercury & & & & & & $<0.00004$ & & & & & \\
\hline Molybdenum & & & & & & $<0.001$ & & & & & \\
\hline Nickel & & & & & & $<0.0018$ & & & & & \\
\hline Potassium & & 1.91 & & & & 1.98 & & & & 1.89 & \\
\hline Selenium & & & & & & $<0.000535$ & & & & & \\
\hline Silver & & & & & & $<0.0012$ & & & & & \\
\hline Sodium & & 37.9 & & & & 34.7 & & & & 52.5 & \\
\hline Thallium & & & & & & $<0.000175$ & & & & & \\
\hline Vanadium & & & & & & $<0.0006$ & & & & & \\
\hline Zinc & & & & & & 0.0273 & & & & & \\
\hline General Chemistry (mg/l unless otherwise noted) & & & & & & & & & & & \\
\hline Ammonia & & & & & & $<0.06$ & & & & & \\
\hline Total Alkalinity & & 50 & & & & 49.2 & & & & 74.8 & \\
\hline Bicarbonate Alkalinity as $\mathrm{CaCO} 3$ & & 50 & & & & 49.2 & & & & 74.8 & \\
\hline Chemical Oxygen Demand & & & & & & $9.639 \mathrm{~J}$ & & & & & \\
\hline Chloride & 19.2 & 30.7 & 25.2 & 40.2 & 37.8 & 24.6 & 18.3 & 31.8 & 33.1 & 43.6 & 53.3 \\
\hline Fluoride & & & & & & 0.132 & & & & & \\
\hline Laboratory pH (S.U.) & & & & & & 6.67 & & & & & \\
\hline Nitrate as $\mathrm{N}$ & & & & & & 1.61 & & & & & \\
\hline Nitrate Nitrite Nitrogen & & & & & & & & & & & \\
\hline Specific Conductance (umhos/cm) & & & & & & 623.8 & & & & & \\
\hline Sulfate & 155 & 236 & 199 & 299 & 281 & 206 & 170 & 253 & 279 & 328 & 395 \\
\hline TDS & & 440 & & & & 452 & & & & 908 & \\
\hline Total Hardness & & & & & & & & & & & \\
\hline Total Organic Carbon & & & & & & 1.54 & & & & & \\
\hline Turbidity (NTU) & & 7.71 & & & & 3.32 & & & & 1.75 & \\
\hline
\end{tabular}

Notes:

$<-$ Analyte was not detected above the indicated Laboratory Reporting Limit.

$\mathrm{J}$ - The analyte was positively identified but the value is estimated as it is below the Laboratory Reporting Limit but above the Method Detection Limit

B - Compound was found in the blank and sample. 
Table A-2 (Page 8 of 8 )

Spring-2

\begin{tabular}{|c|c|c|c|c|c|}
\hline & Spring-2 & Spring-2 & Spring-2 & Spring-2 & Spring-2 \\
\hline Date Sampled: & $5 / 18 / 2015$ & $5 / 26 / 2015$ & $6 / 1 / 2015$ & $6 / 8 / 2015$ & $6 / 15 / 2015$ \\
\hline \multicolumn{6}{|l|}{ Field Parameters } \\
\hline Flow (gpm) & $<0.5$ & $<0.5$ & $<0.5$ & $<0.5$ & $<0.5$ \\
\hline pH (S.U.) & 7.35 & 7.15 & 7.16 & 7.36 & 6.88 \\
\hline ORP (mV) & 105 & 102 & 15.8 & 166 & 186 \\
\hline \multicolumn{6}{|l|}{ Dissolved Oxygen (mg/l) } \\
\hline Conductivity (umhos/cm) & 1126 & 1282 & 1256 & 1505 & 1066 \\
\hline Temperature (C) & 14.9 & 15.7 & 11.96 & 17 & 14.1 \\
\hline \multicolumn{6}{|l|}{ Dissolved Metals (mg/l) } \\
\hline \multicolumn{6}{|l|}{ Aluminum } \\
\hline \multicolumn{6}{|l|}{ Antimony } \\
\hline \multicolumn{6}{|l|}{ Arsenic } \\
\hline \multicolumn{6}{|l|}{ Barium } \\
\hline Beryllium & & & & & \\
\hline Boron & & & & & \\
\hline Cadmium & & & & & \\
\hline Calcium & & & & & \\
\hline Chromium & & & & & \\
\hline Cobalt & & & & & \\
\hline Copper & & & & & \\
\hline Cyanide & & & & & \\
\hline Iron & & & & & \\
\hline Lead & & & & & \\
\hline Magnesium & & & & & \\
\hline Manganese & & & & & \\
\hline Mercury & & & & & \\
\hline Molybdenum & & & & & \\
\hline Nickel & & & & & \\
\hline Potassium & & & & & \\
\hline Selenium & & & & & \\
\hline Silver & & & & & \\
\hline Sodium & & & & & \\
\hline Thallium & & & & & \\
\hline Vanadium & & & & & \\
\hline Zinc & & & & & \\
\hline Total Metals $(\mathrm{mg} / \mathrm{l})$ & & & & & \\
\hline Aluminum & & & & & \\
\hline Antimony & & & & & \\
\hline Arsenic & & & 0.0012 & & \\
\hline Barium & & & & & \\
\hline Beryllium & & & & & \\
\hline Boron & & & 0.327 & & \\
\hline Cadmium & & & & & \\
\hline Calcium & & & 138 & & \\
\hline Chromium & & & & & \\
\hline Cobalt & & & & & \\
\hline Copper & & & & & \\
\hline Cyanide & & & & & \\
\hline Iron & & & 1.24 & & \\
\hline Lead & & & & & \\
\hline Magnesium & & & 67 & & \\
\hline Manganese & & & 0.0818 & & \\
\hline Mercury & & & & & \\
\hline Molybdenum & & & & & \\
\hline Nickel & & & & & \\
\hline Potassium & & & 2.66 & & \\
\hline Selenium & & & & & \\
\hline Silver & & & & & \\
\hline Sodium & & & $80.7 \mathrm{~B}$ & & \\
\hline Thallium & & & & & \\
\hline Vanadium & & & & & \\
\hline Zinc & & & & & \\
\hline General Chemistry (mg/l unless otherwise noted) & & & & & \\
\hline Ammonia & & & & & \\
\hline Total Alkalinity & & & 104 & & \\
\hline Bicarbonate Alkalinity as $\mathrm{CaCO} 3$ & & & 104 & & \\
\hline Chemical Oxygen Demand & & & & & \\
\hline Chloride & 57.9 & 70.4 & 79.2 & 90.1 & 55.8 \\
\hline Fluoride & & & & & \\
\hline Laboratory pH (S.U.) & & & & & \\
\hline Nitrate as $\mathrm{N}$ & & & & & \\
\hline Nitrate Nitrite Nitrogen & & & & & \\
\hline Specific Conductance (umhos/cm) & & & & & \\
\hline Sulfate & 418 & 513 & 559 & 598 & 382 \\
\hline TDS & & & 1080 & & \\
\hline Total Hardness & & & & & \\
\hline Total Organic Carbon & & & & & \\
\hline Turbidity (NTU) & & & 31.9 & & \\
\hline
\end{tabular}

Notes:

$<-$ Analyte was not detected above the indicated Laboratory Reporting Limit.

$\mathrm{J}$ - The analyte was positively identified but the value is estimated as it is below the Laboratory Reporting Limit but above the Method Detection Limit

B - Compound was found in the blank and sample. 
APPENDIX B

BORING LOGS 


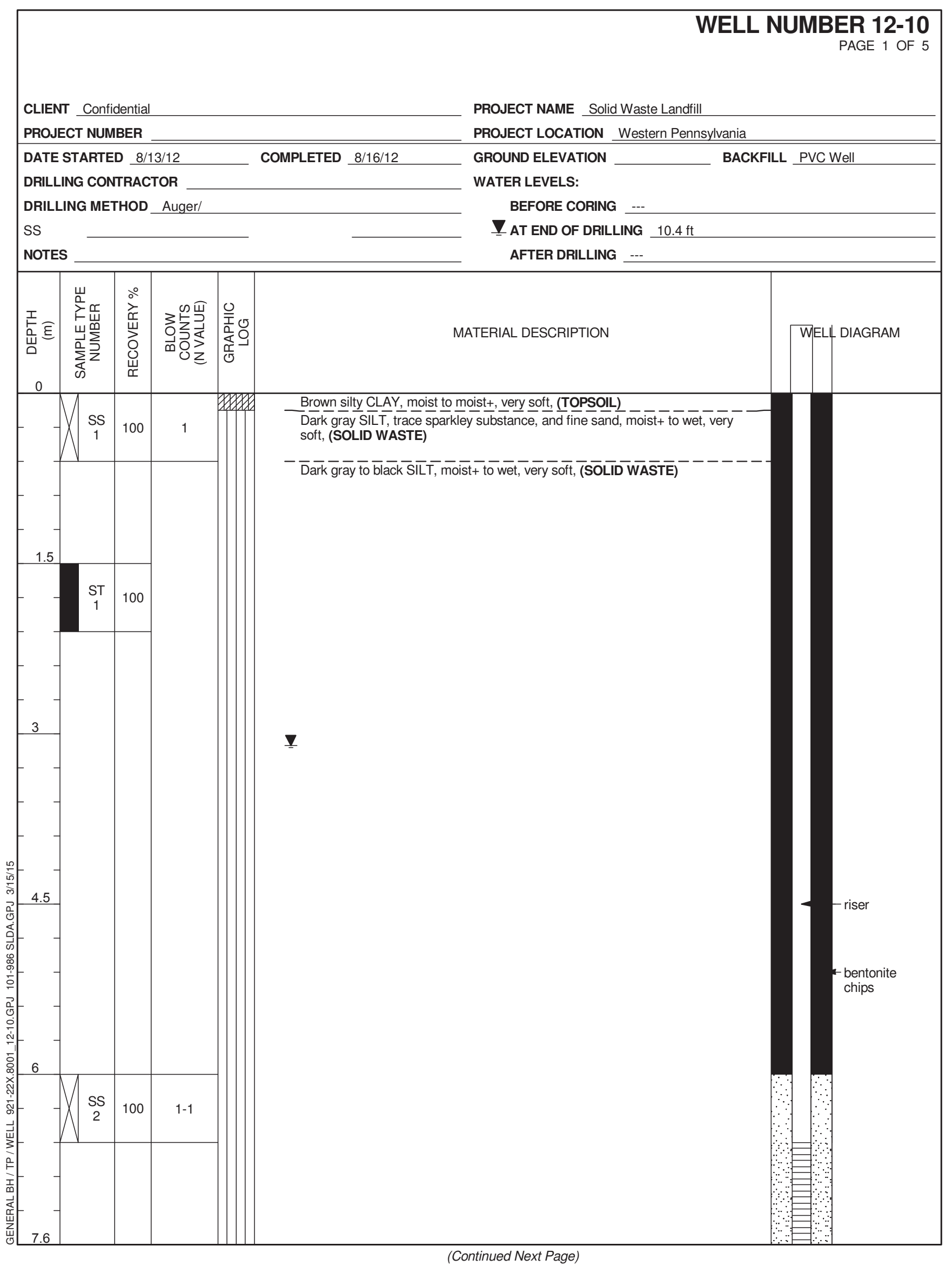

Figure B-1: 12-10 Boring Log 


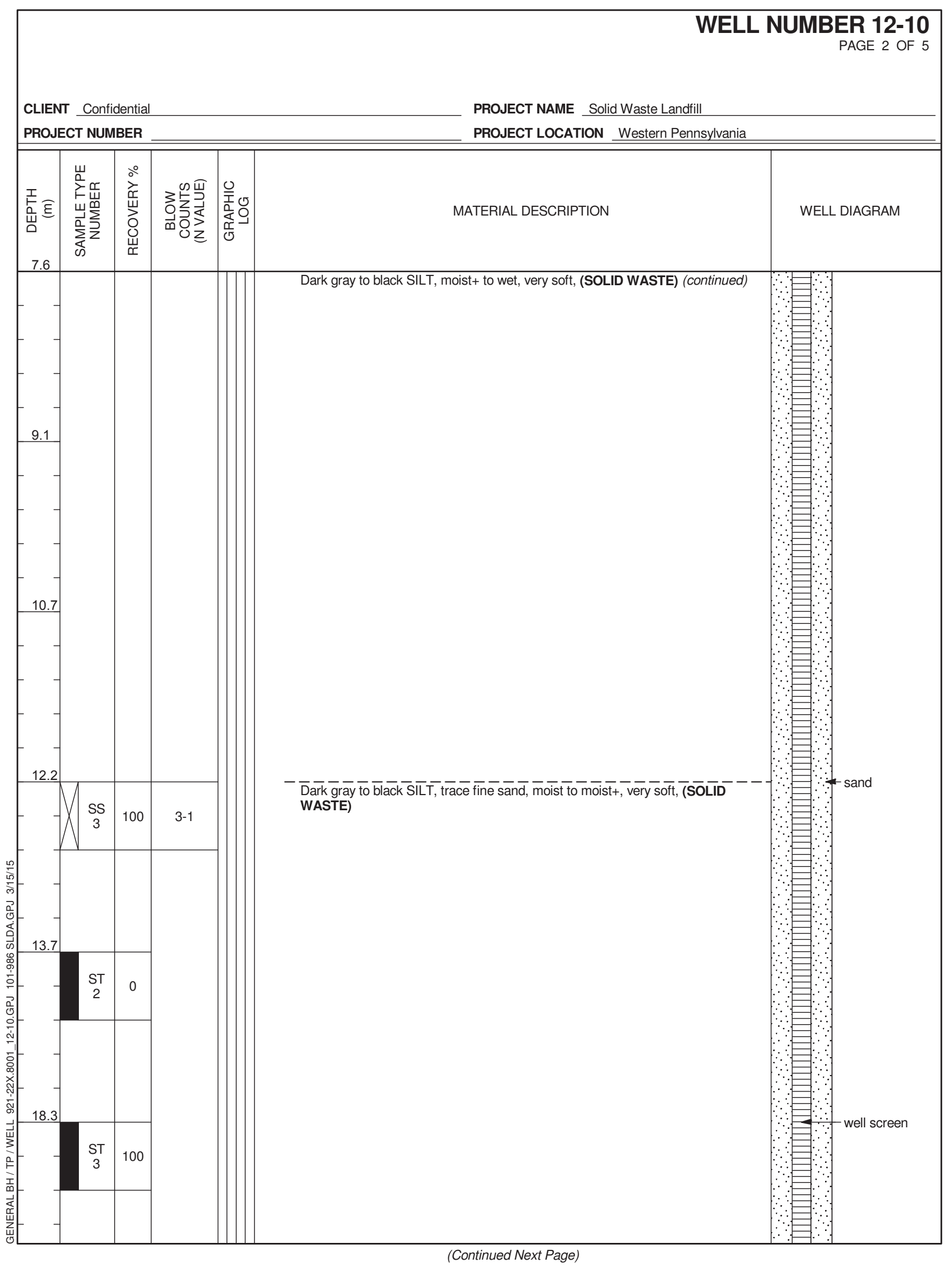




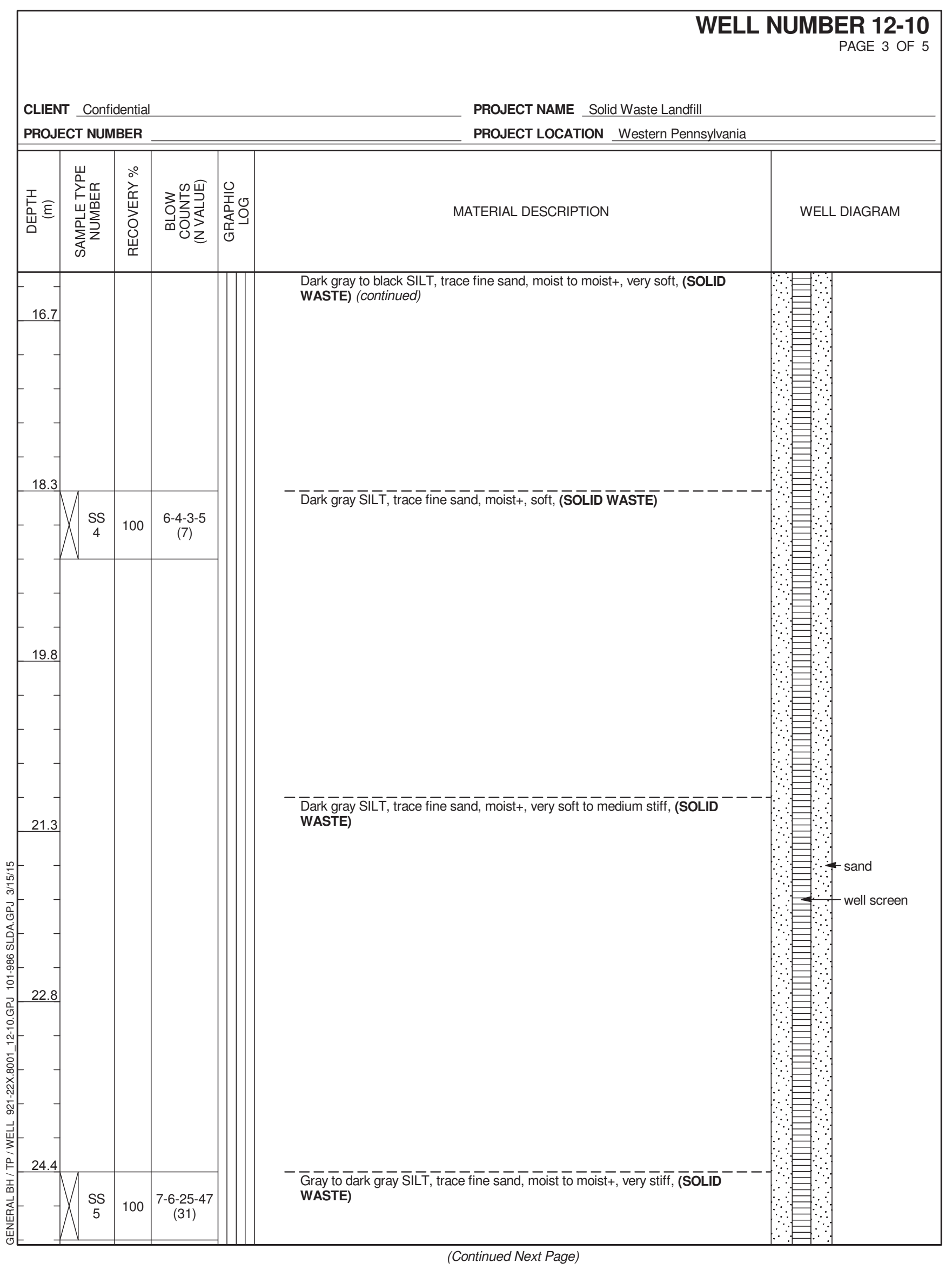




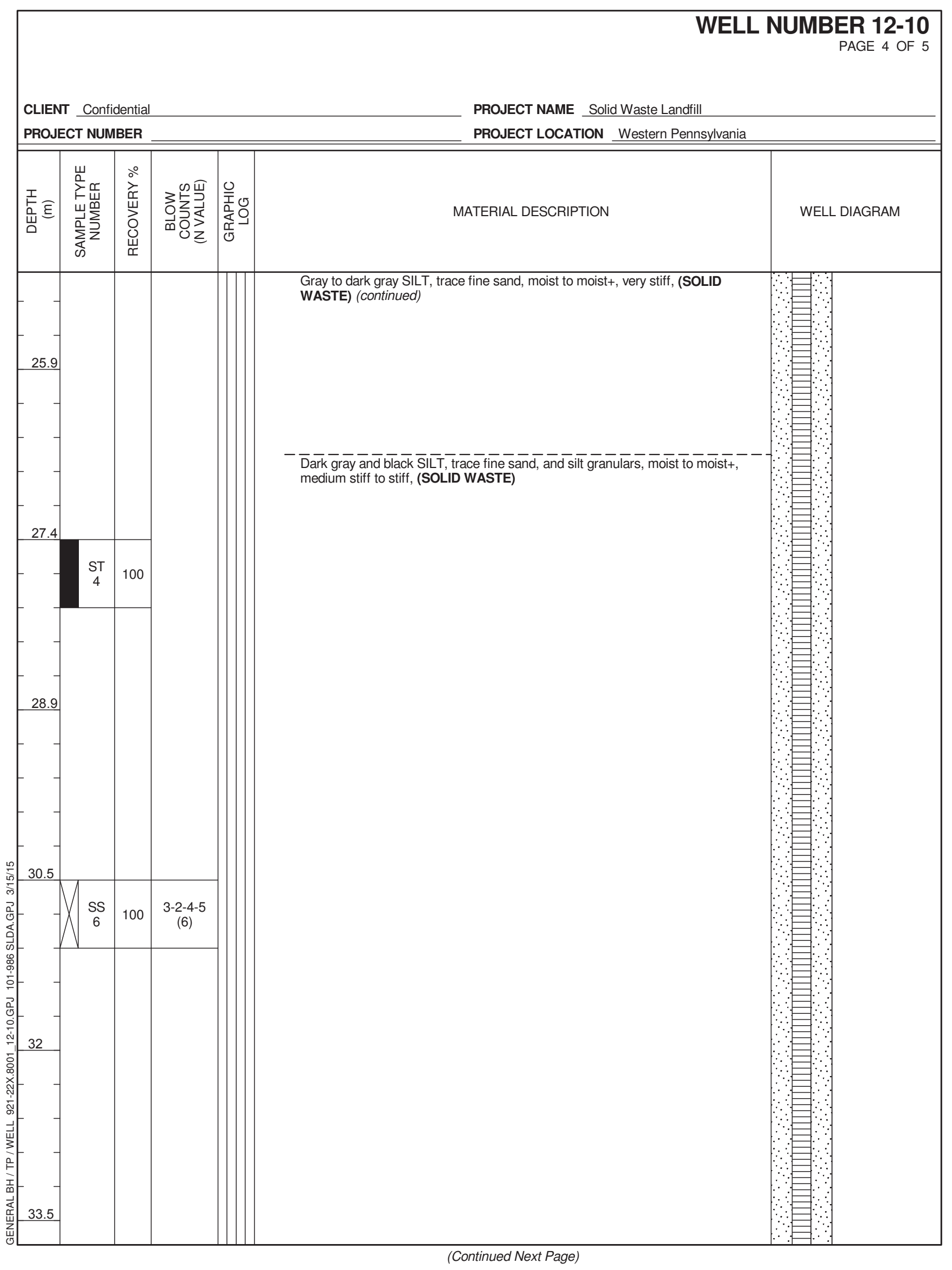




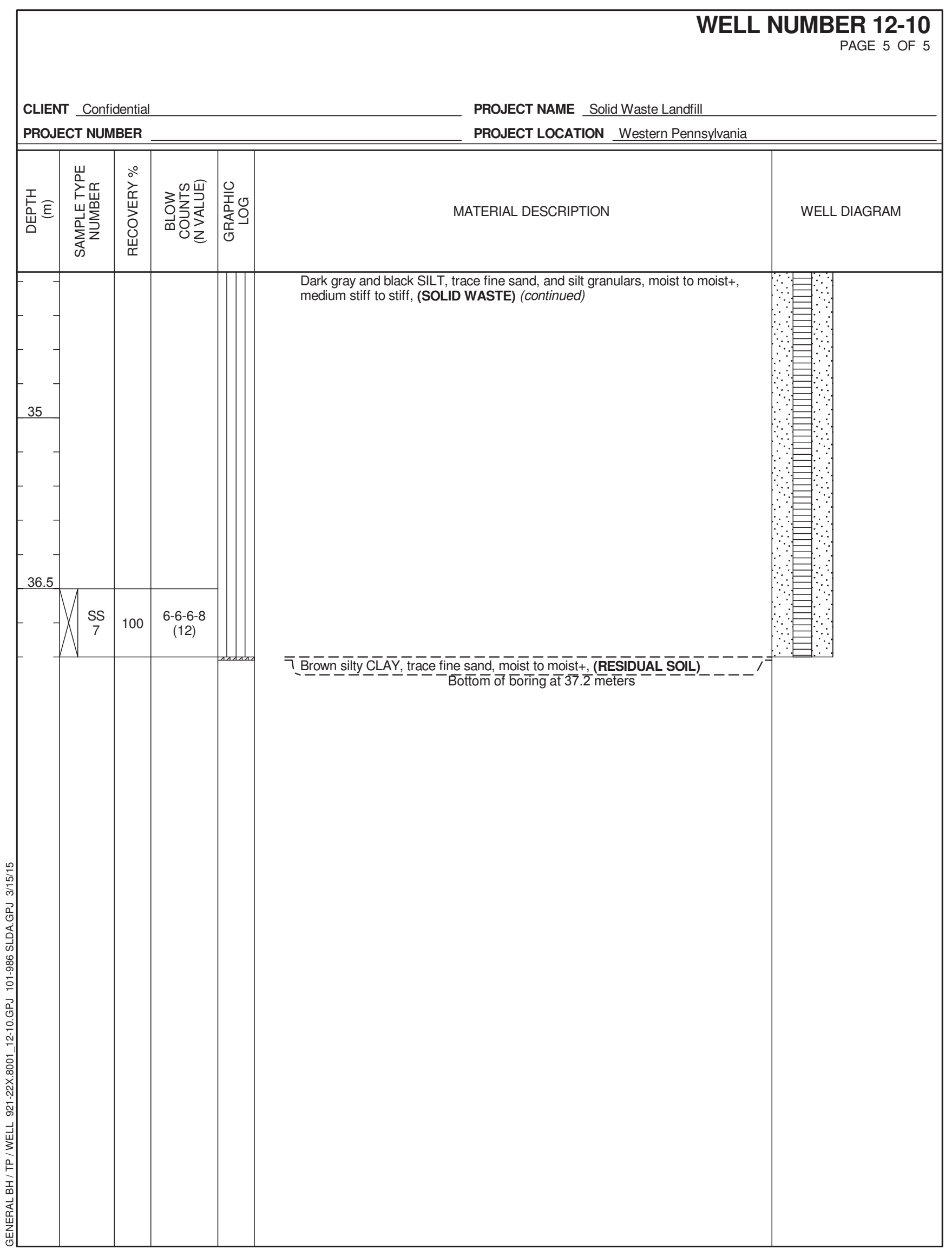




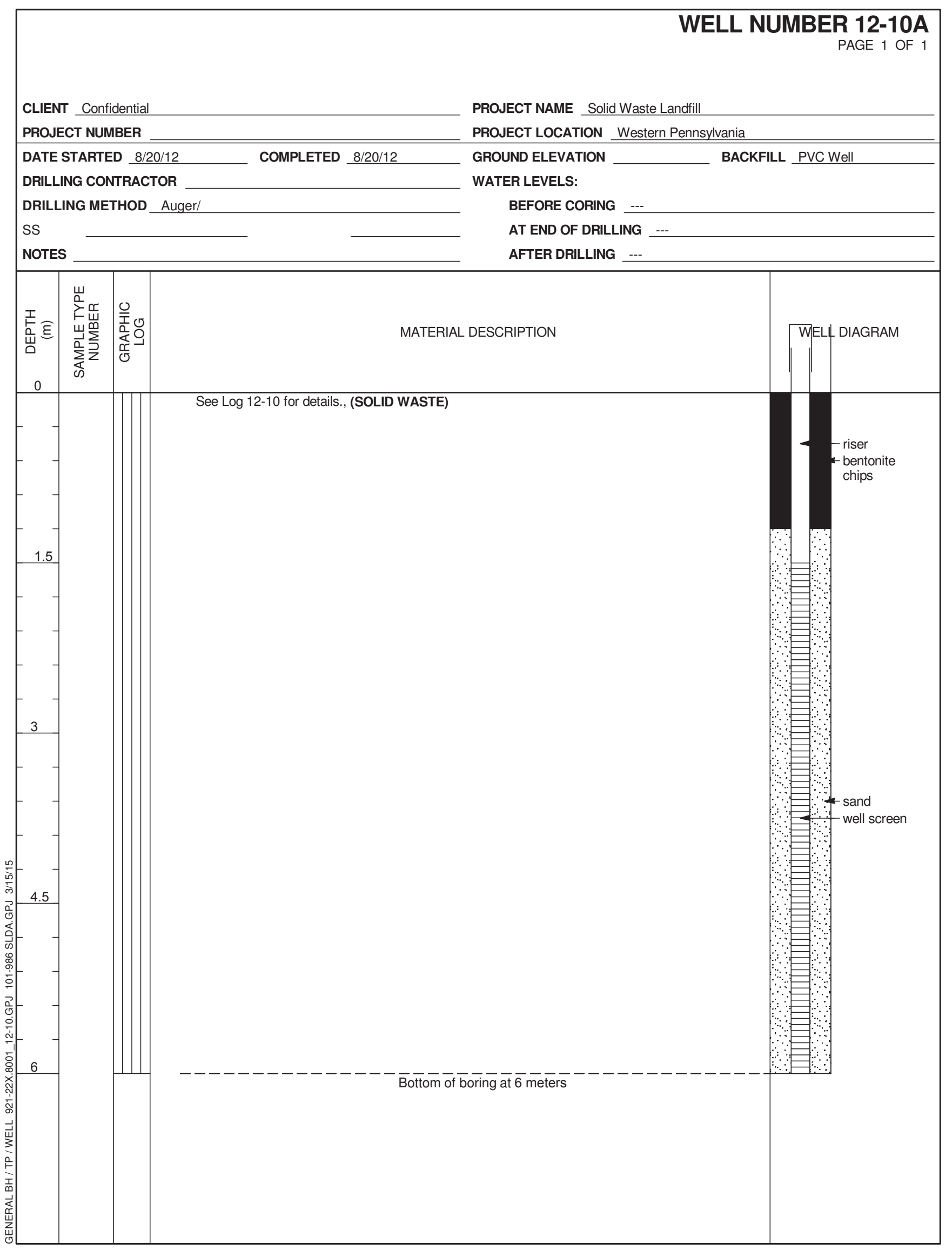

Figure B-2: 12-10A Boring Log 


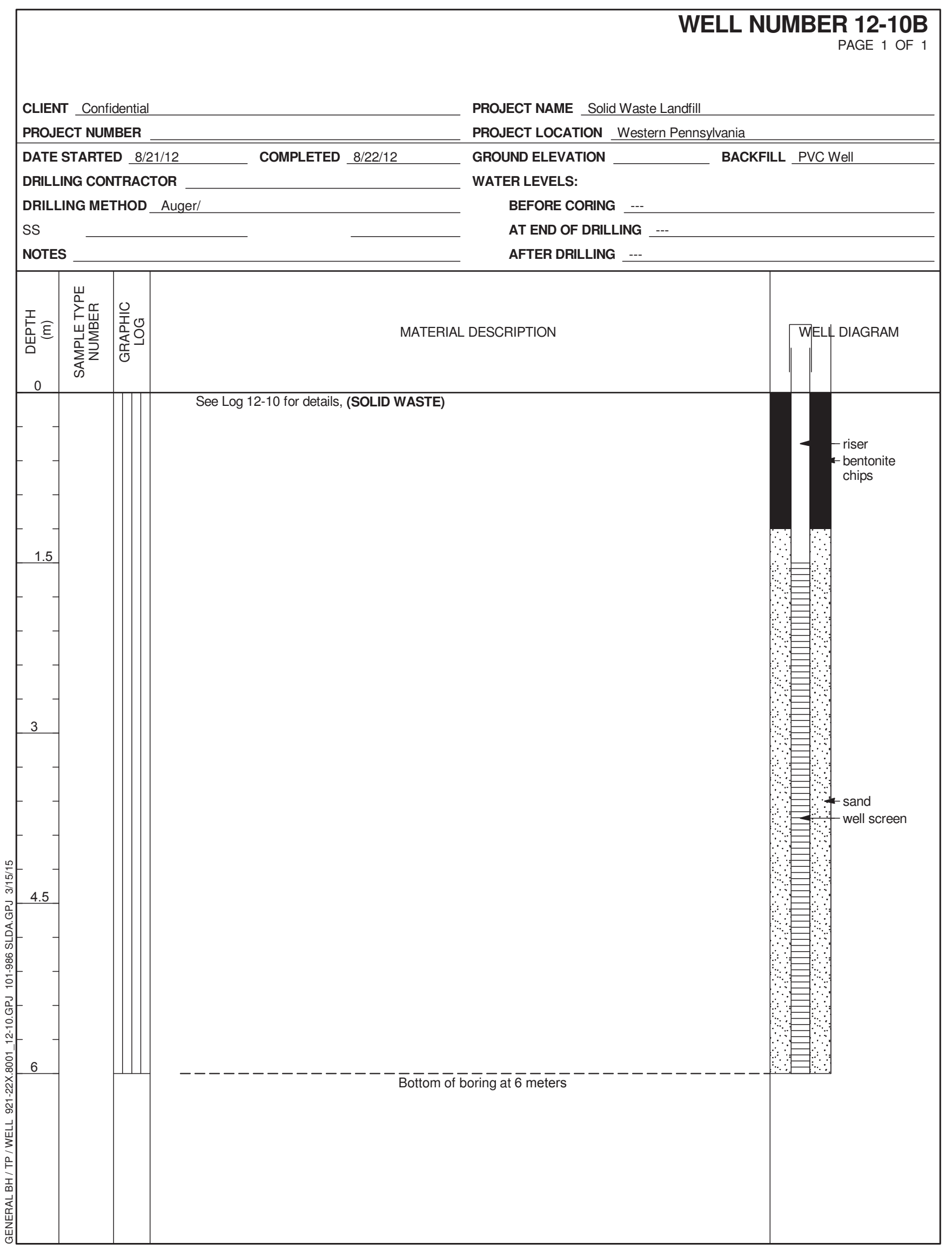

Figure B-3: 12-10B Boring Log 


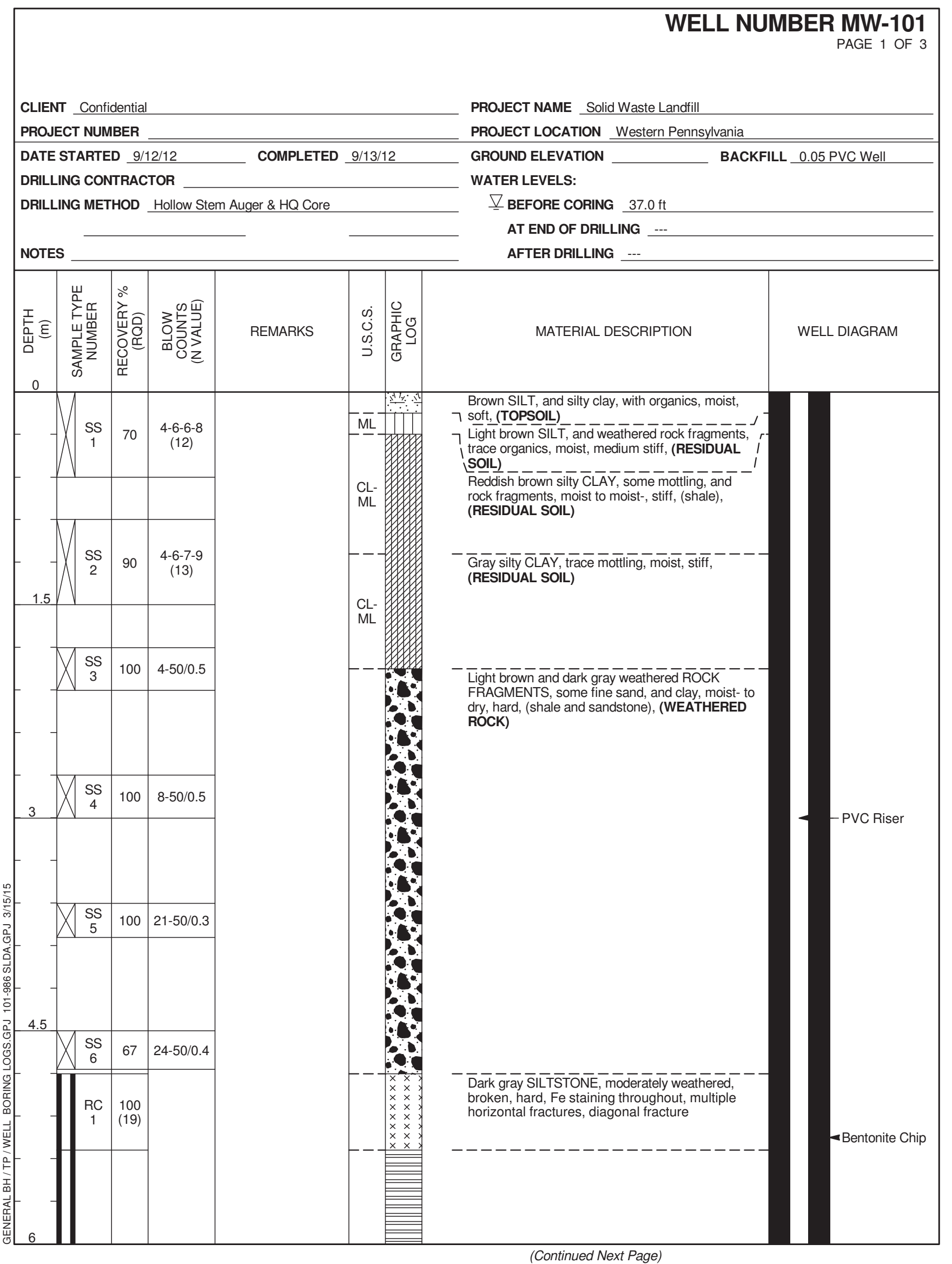

Figure B-4: MW-101 Boring Log 


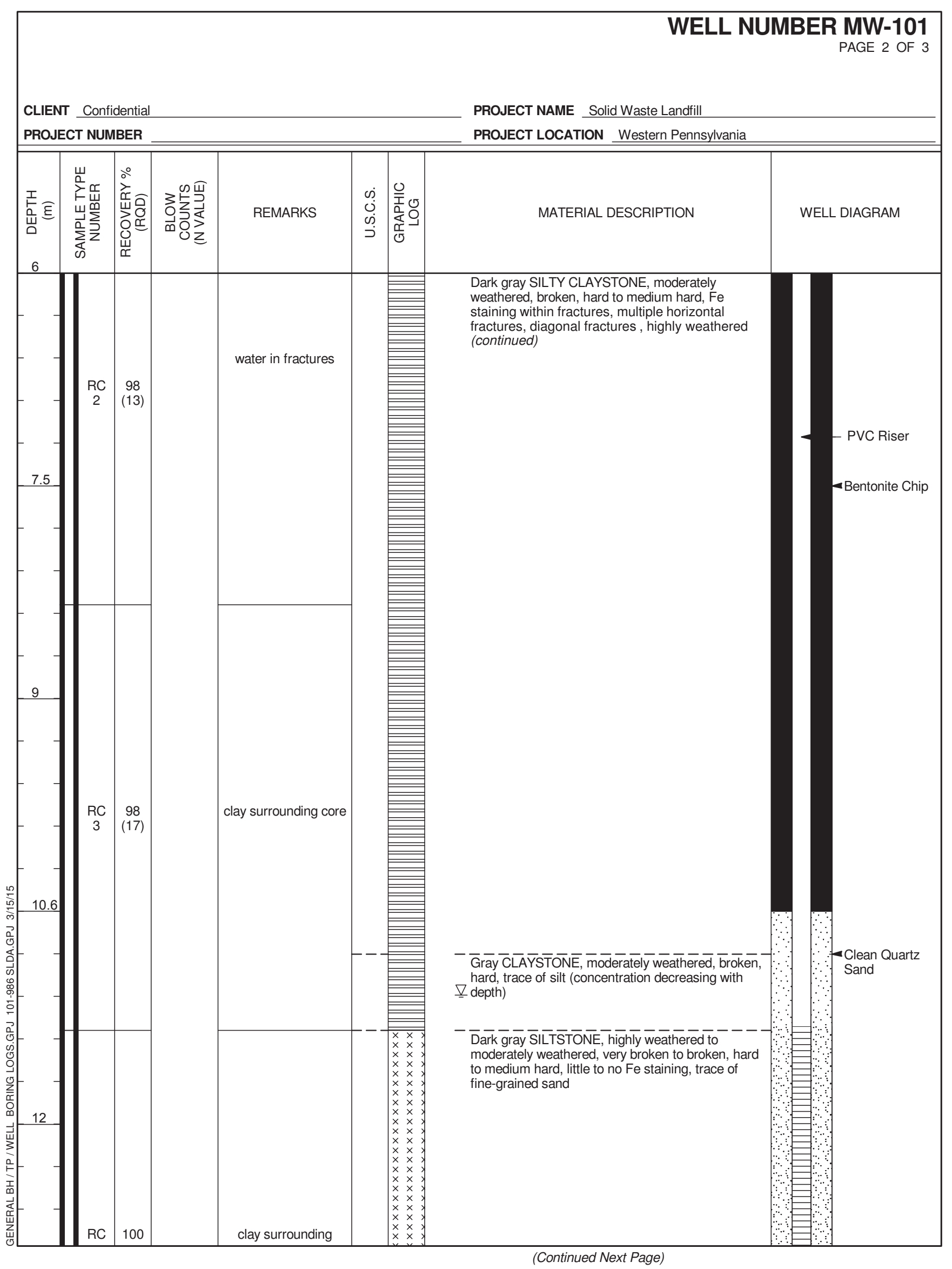




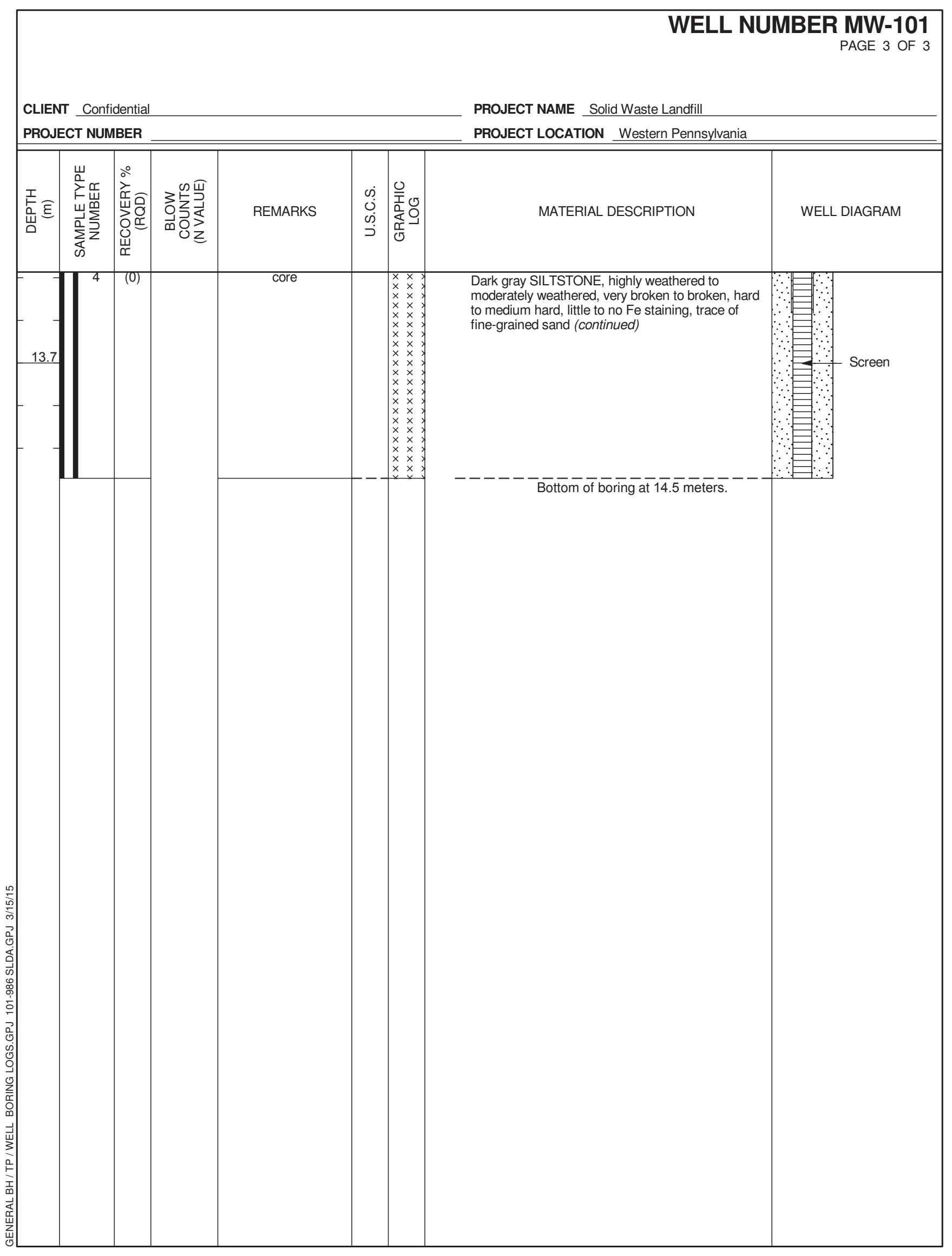




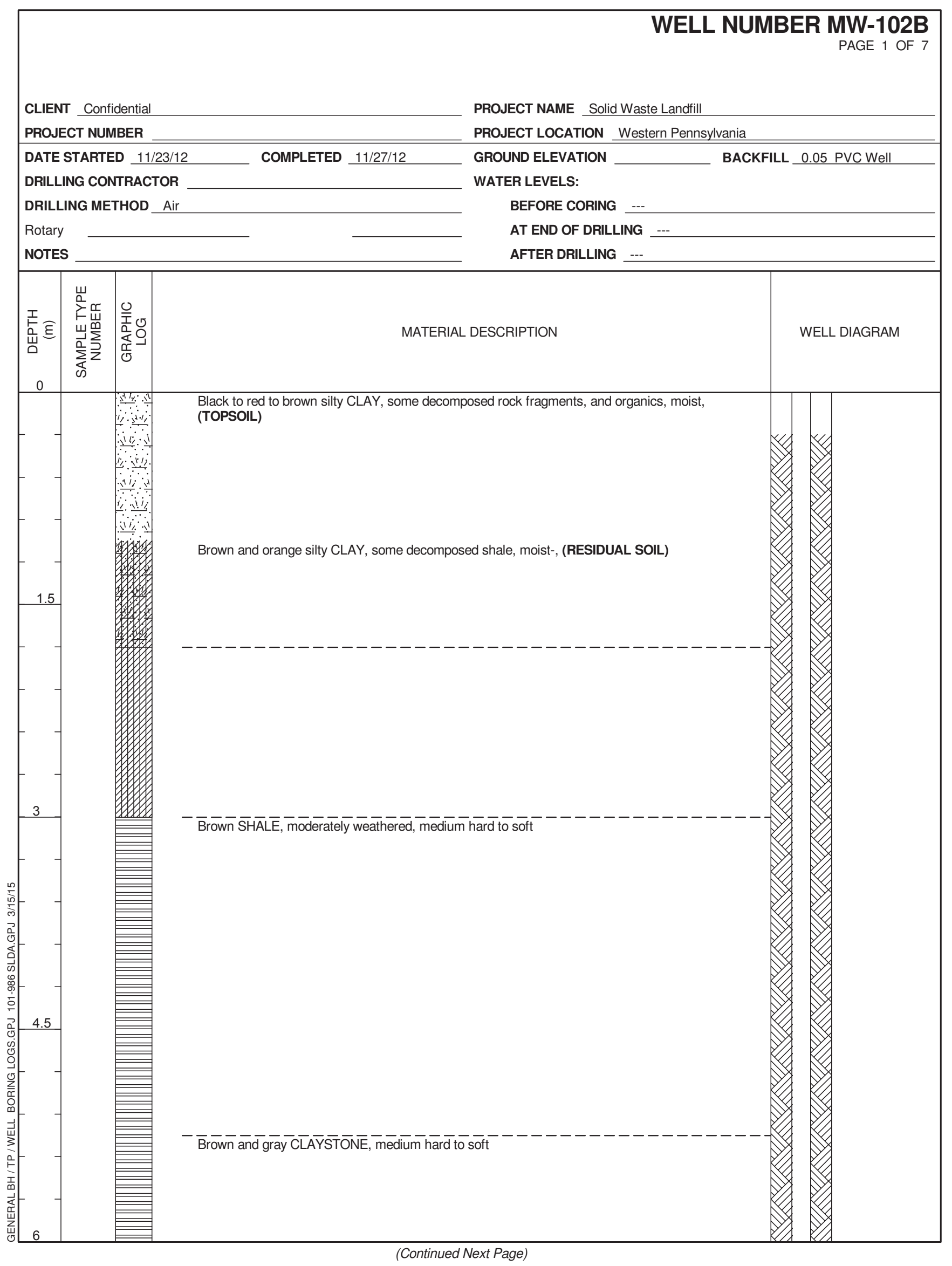

Figure B-5: MW-102B Boring Log 


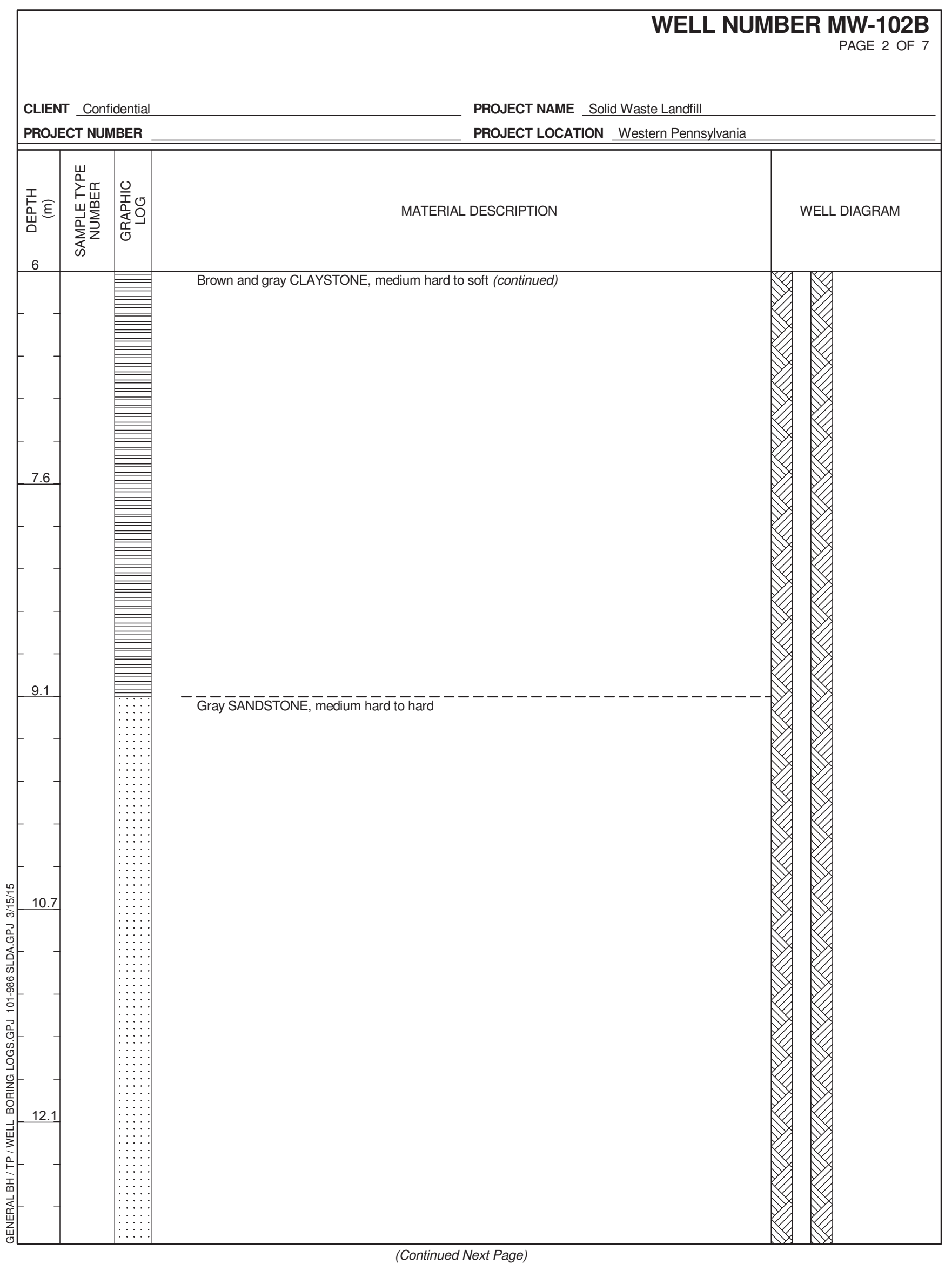




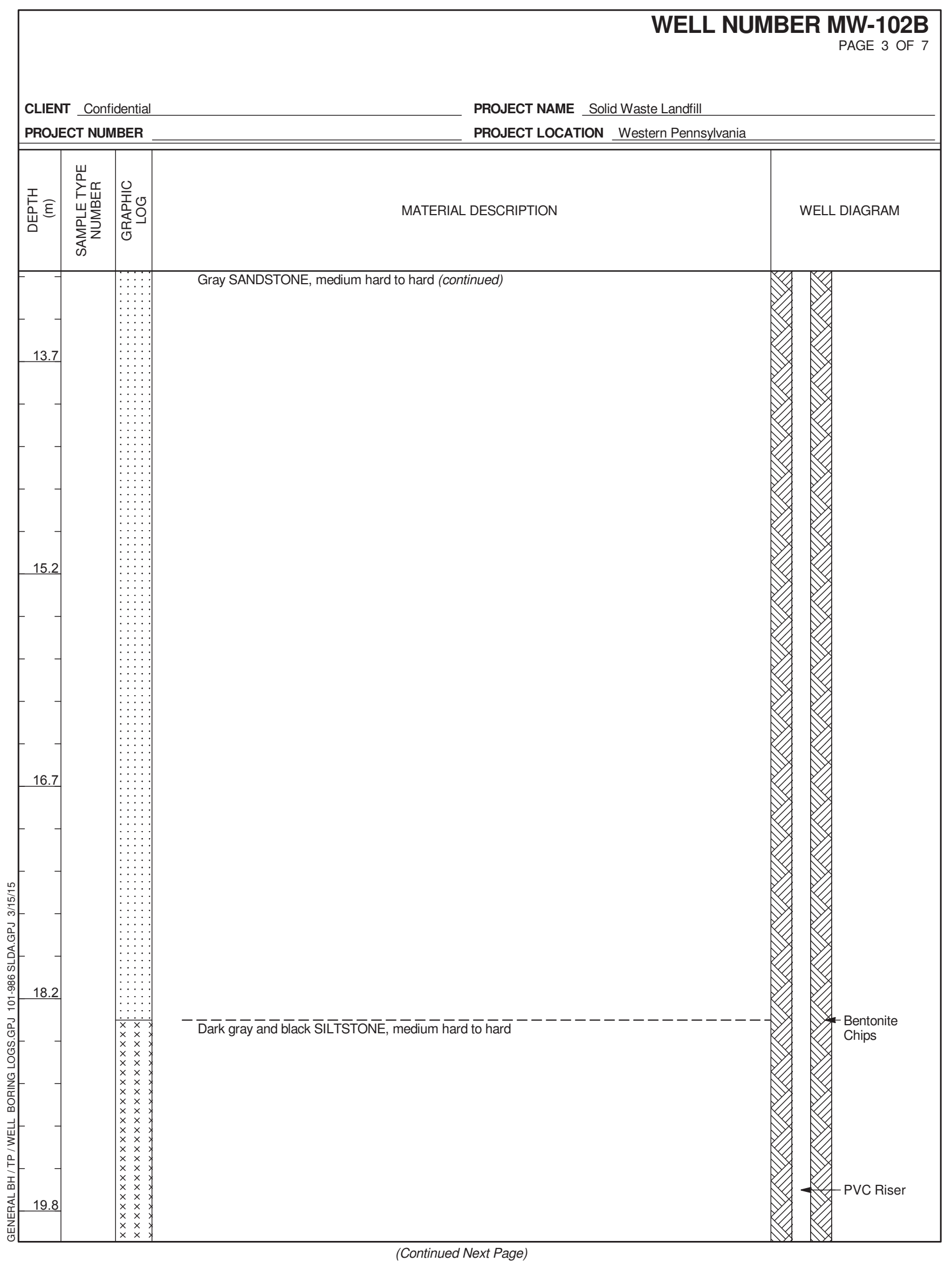




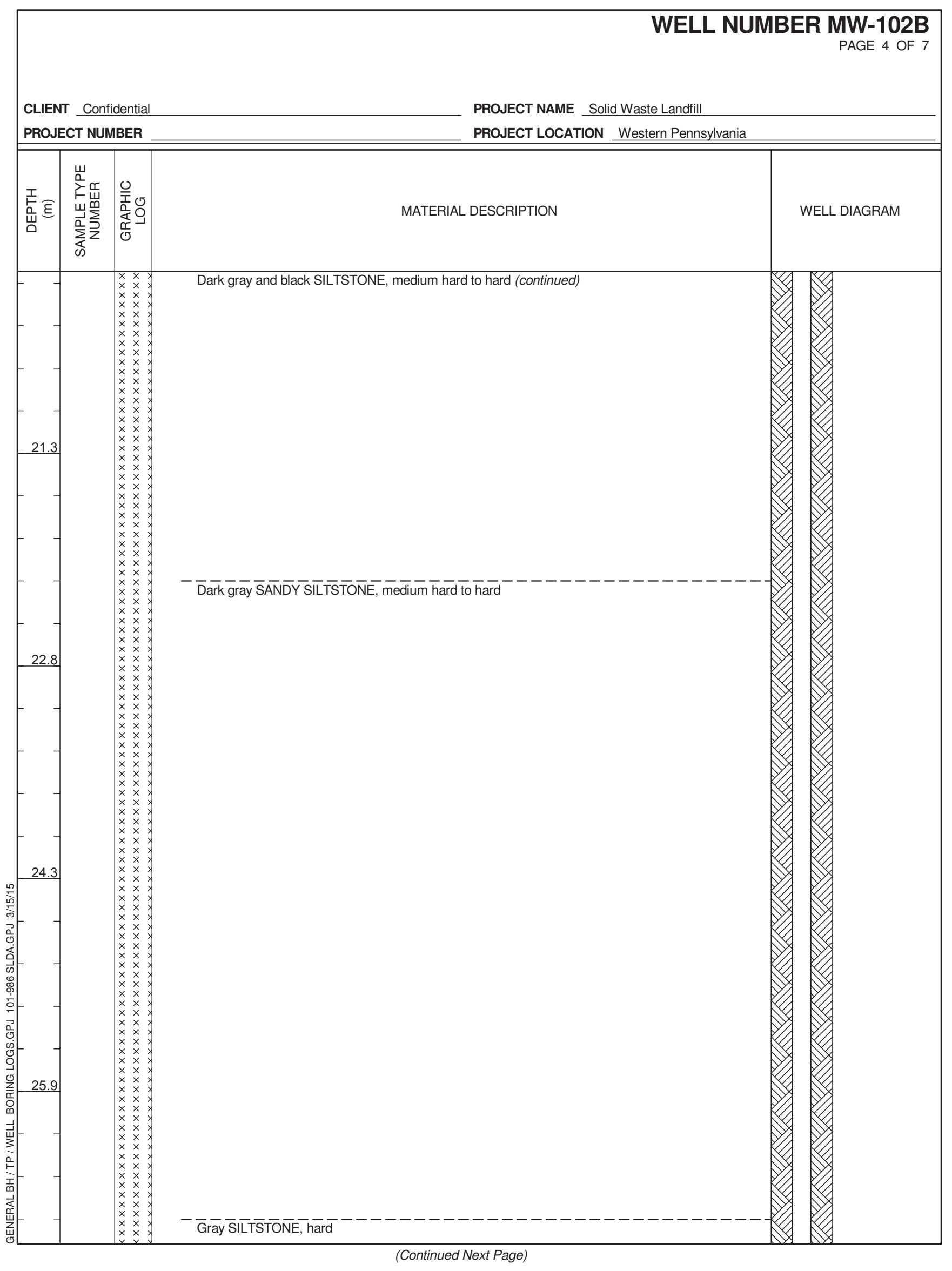




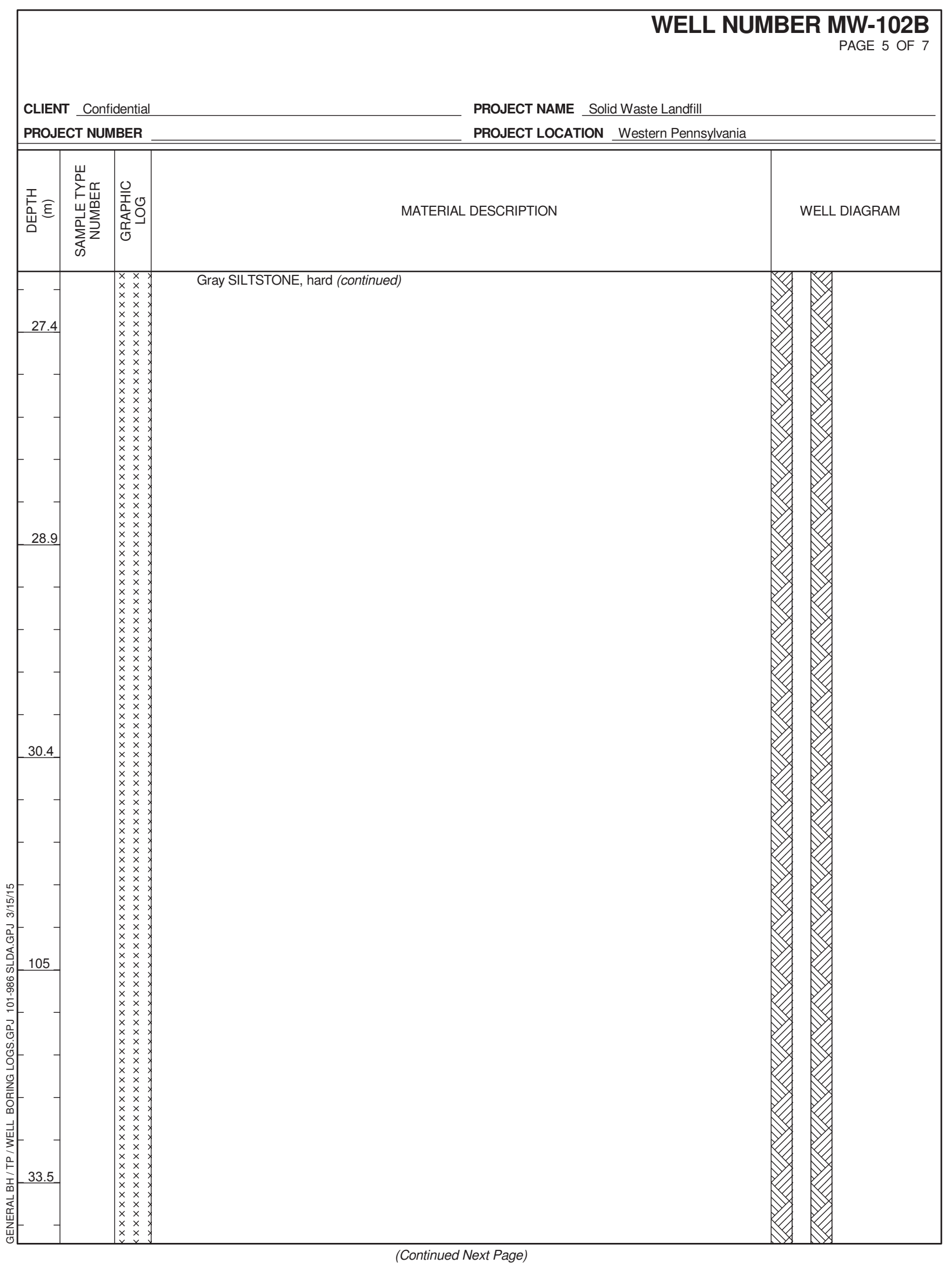




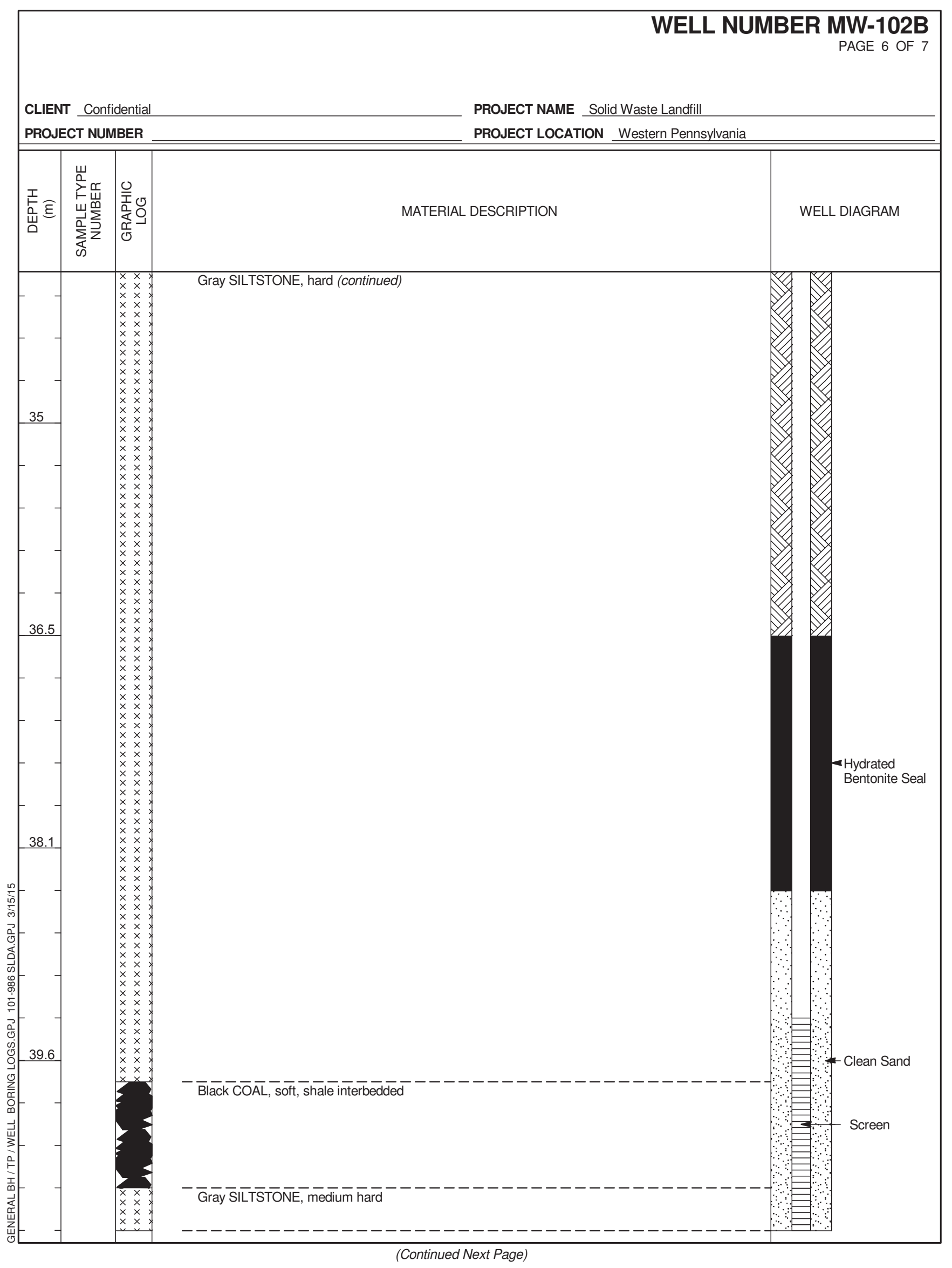




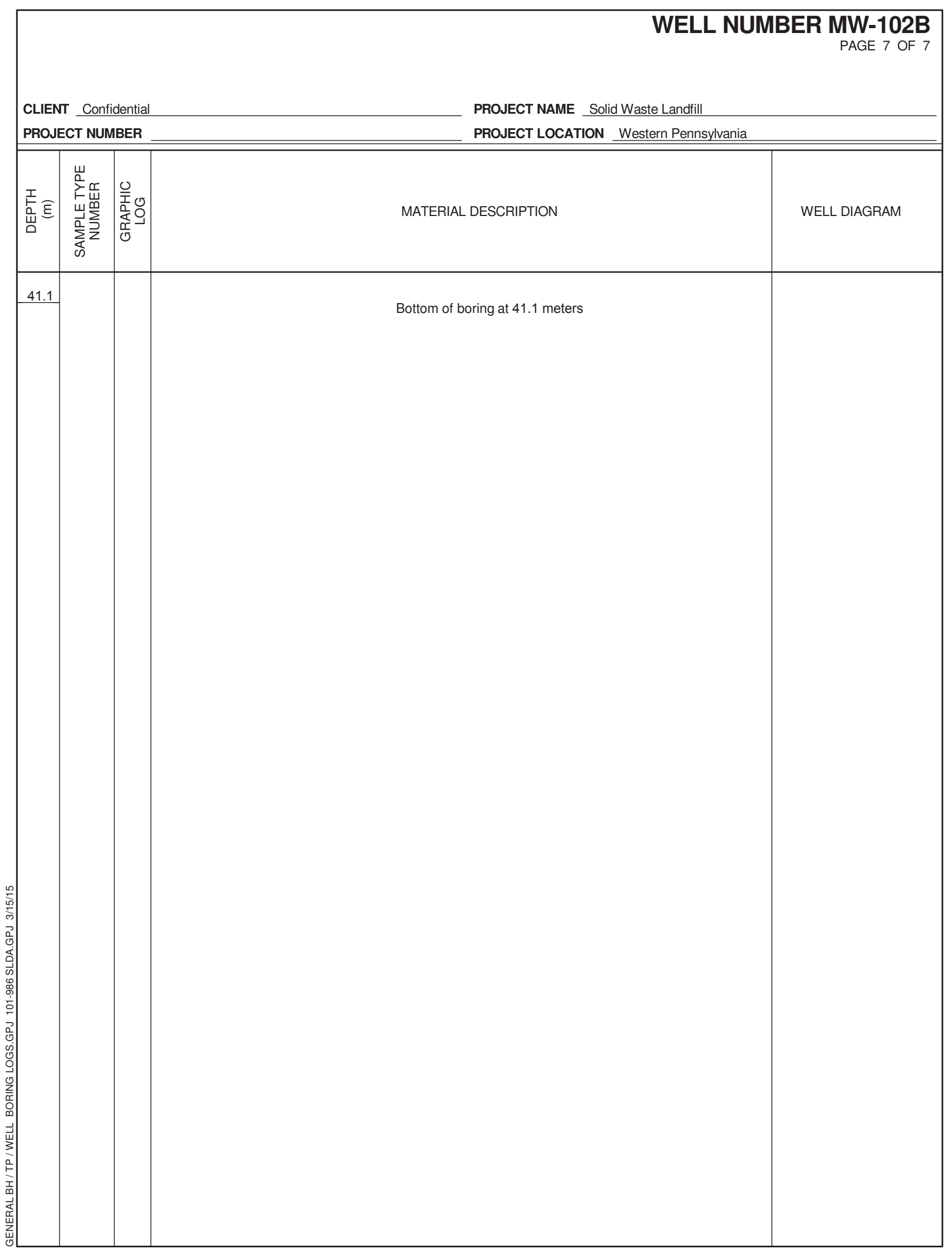




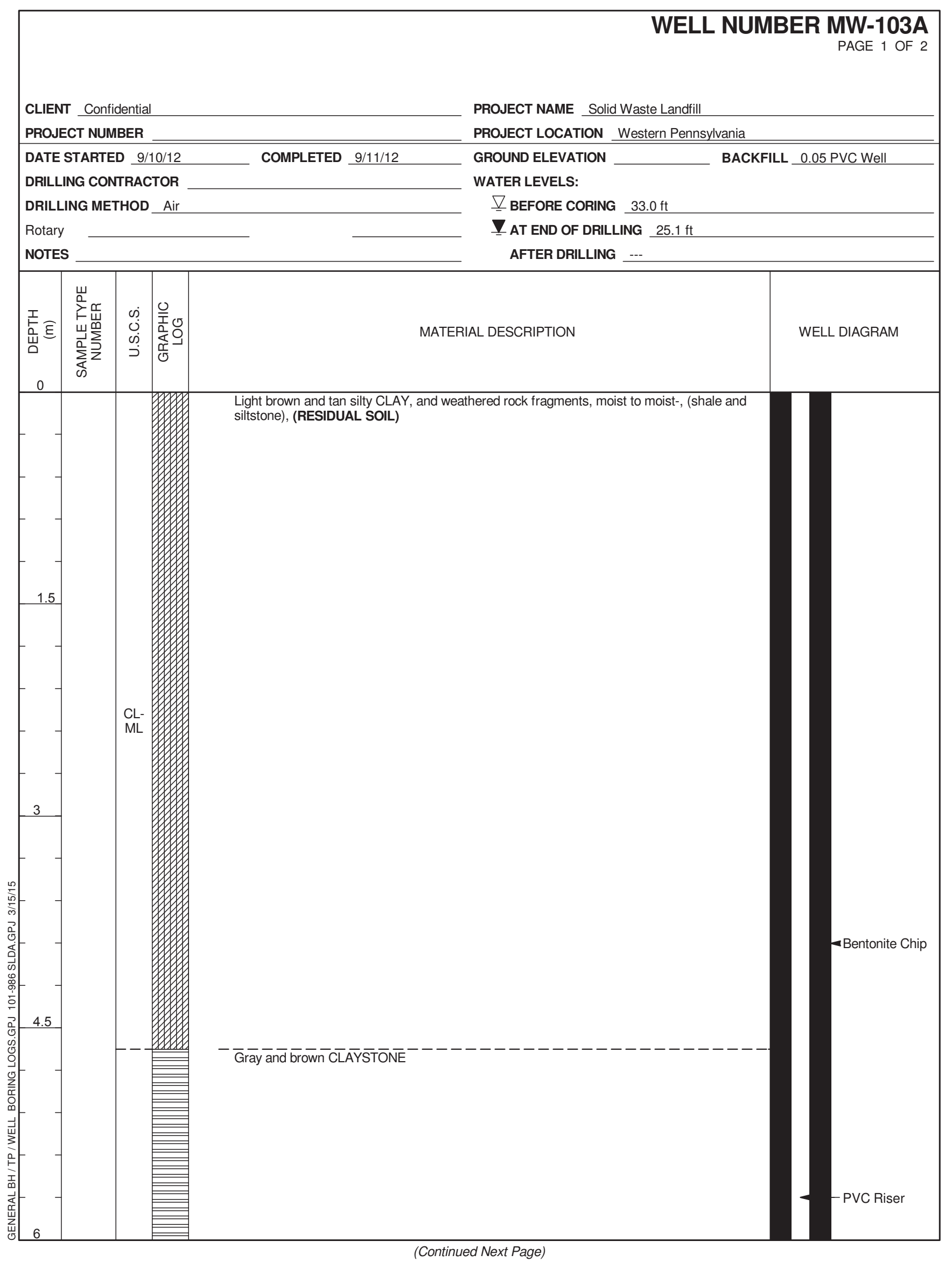

Figure B-6: MW-103A Boring Log 


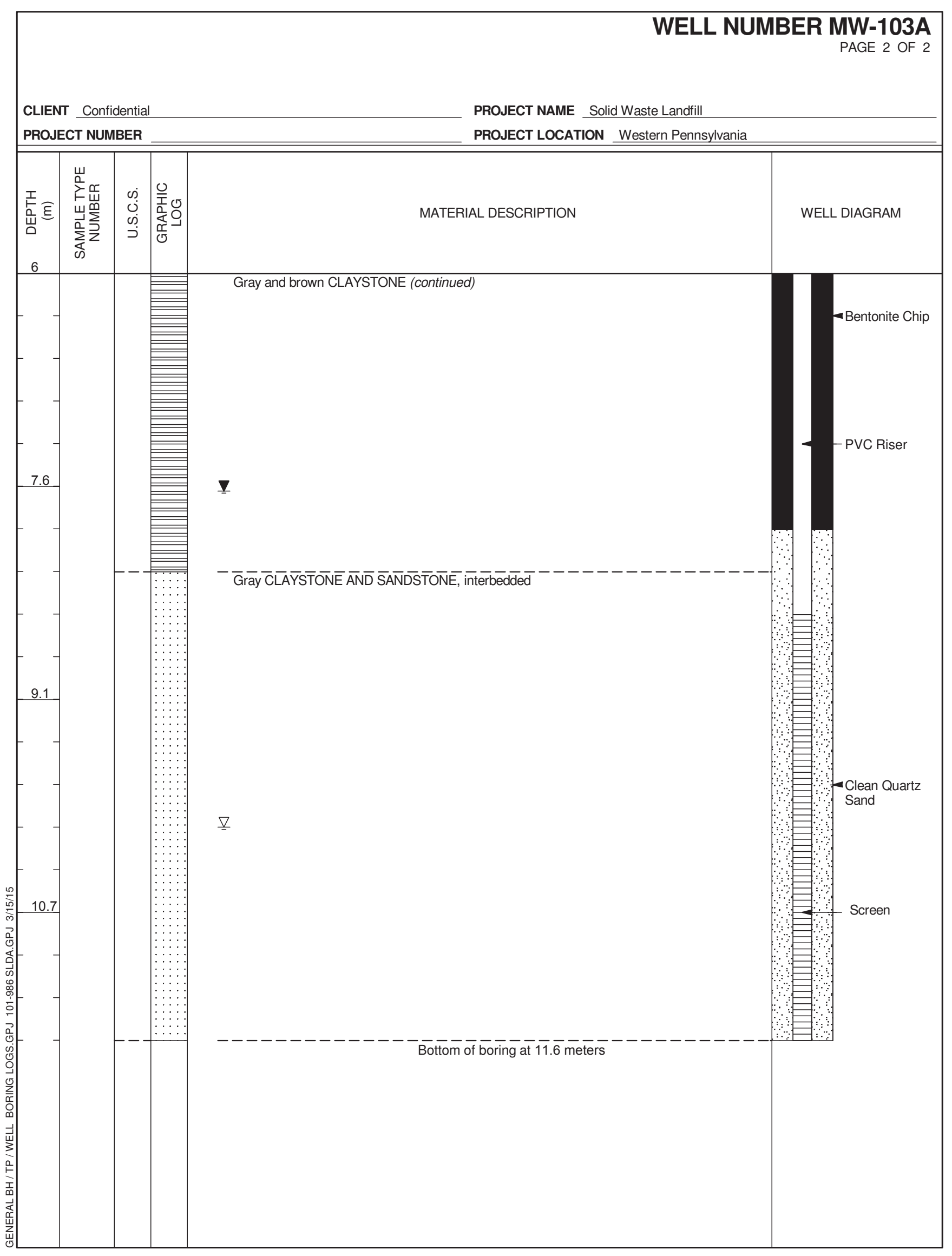




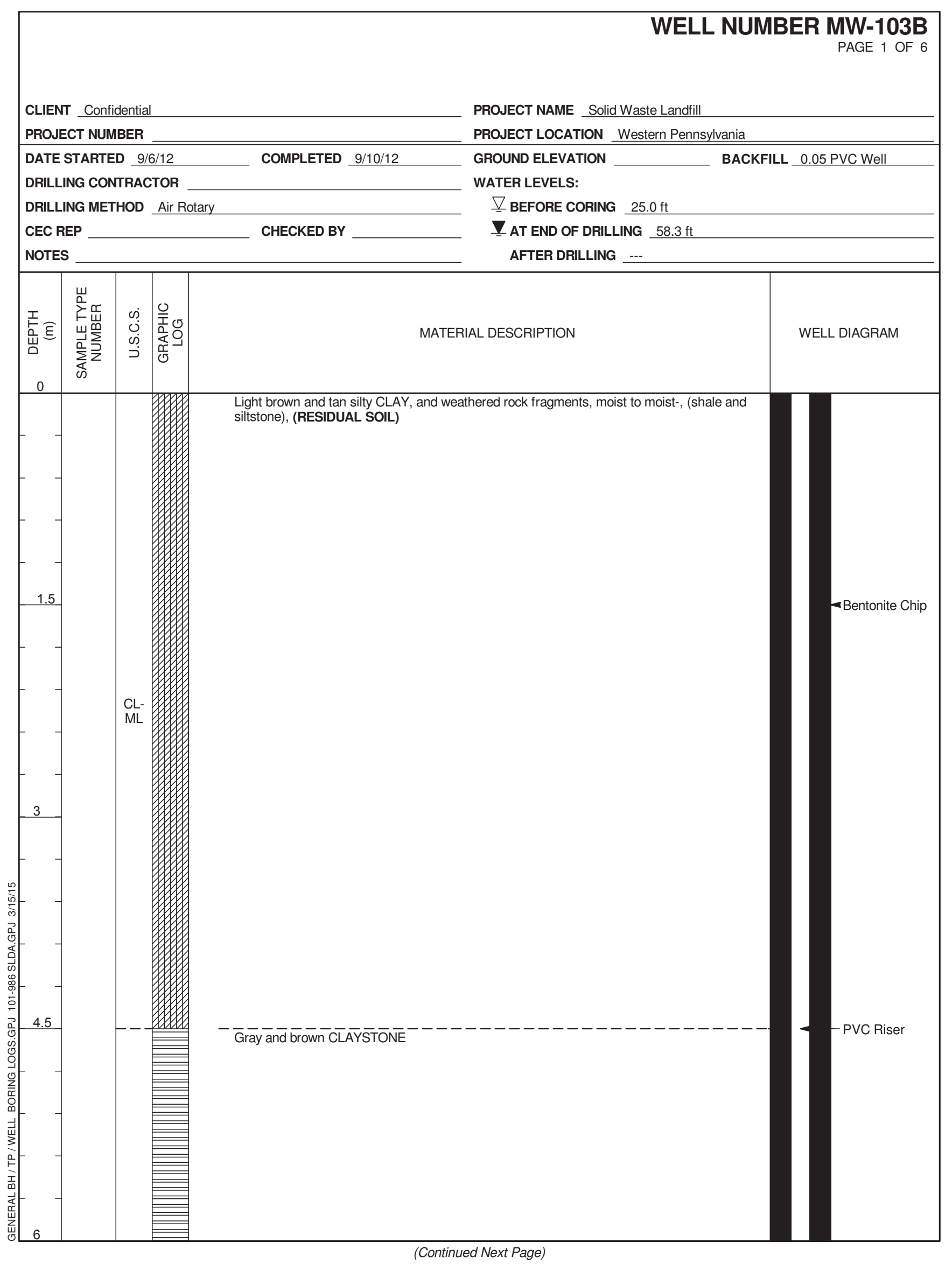

Figure B-7: MW-103B Boring Log 


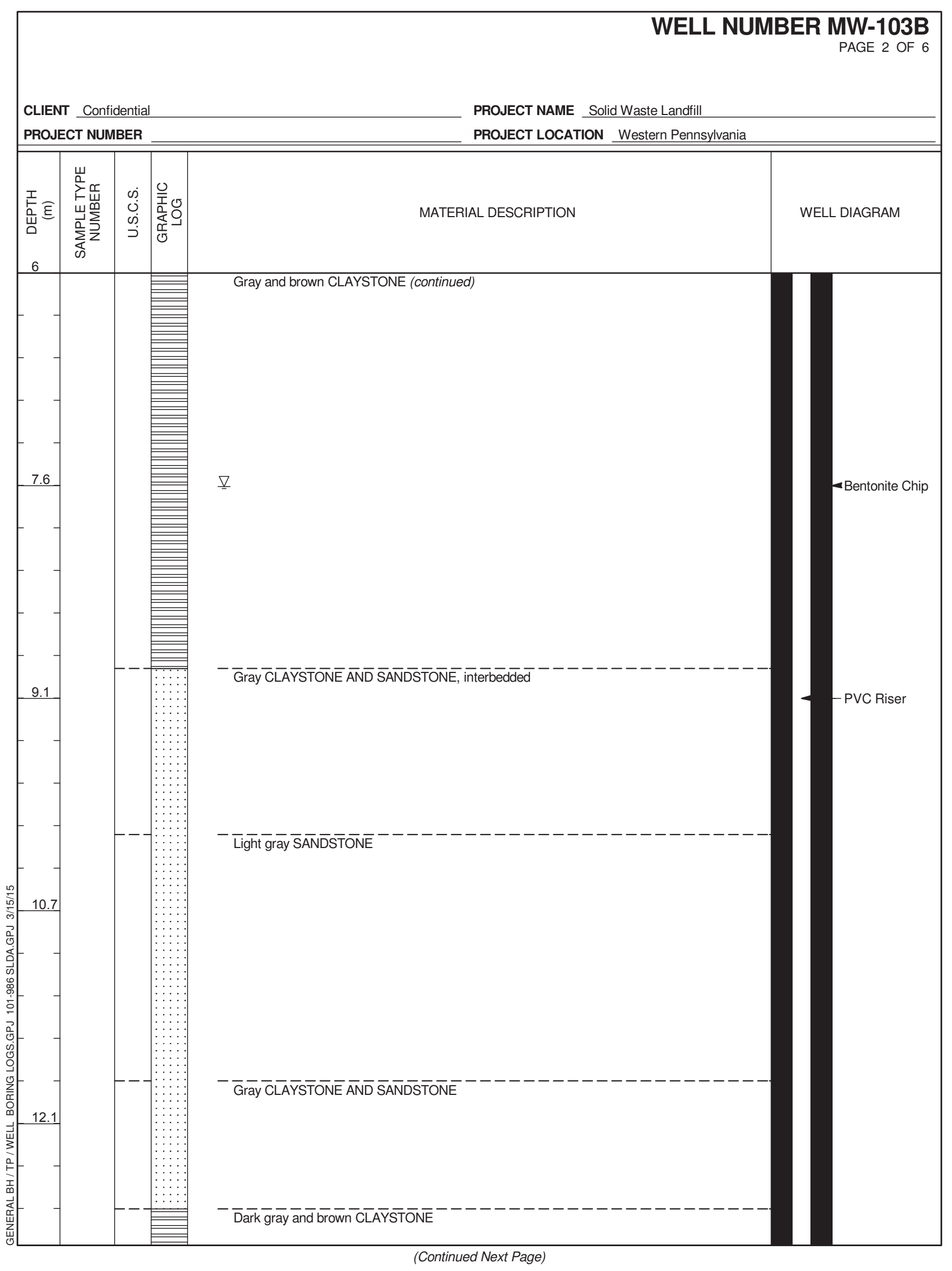




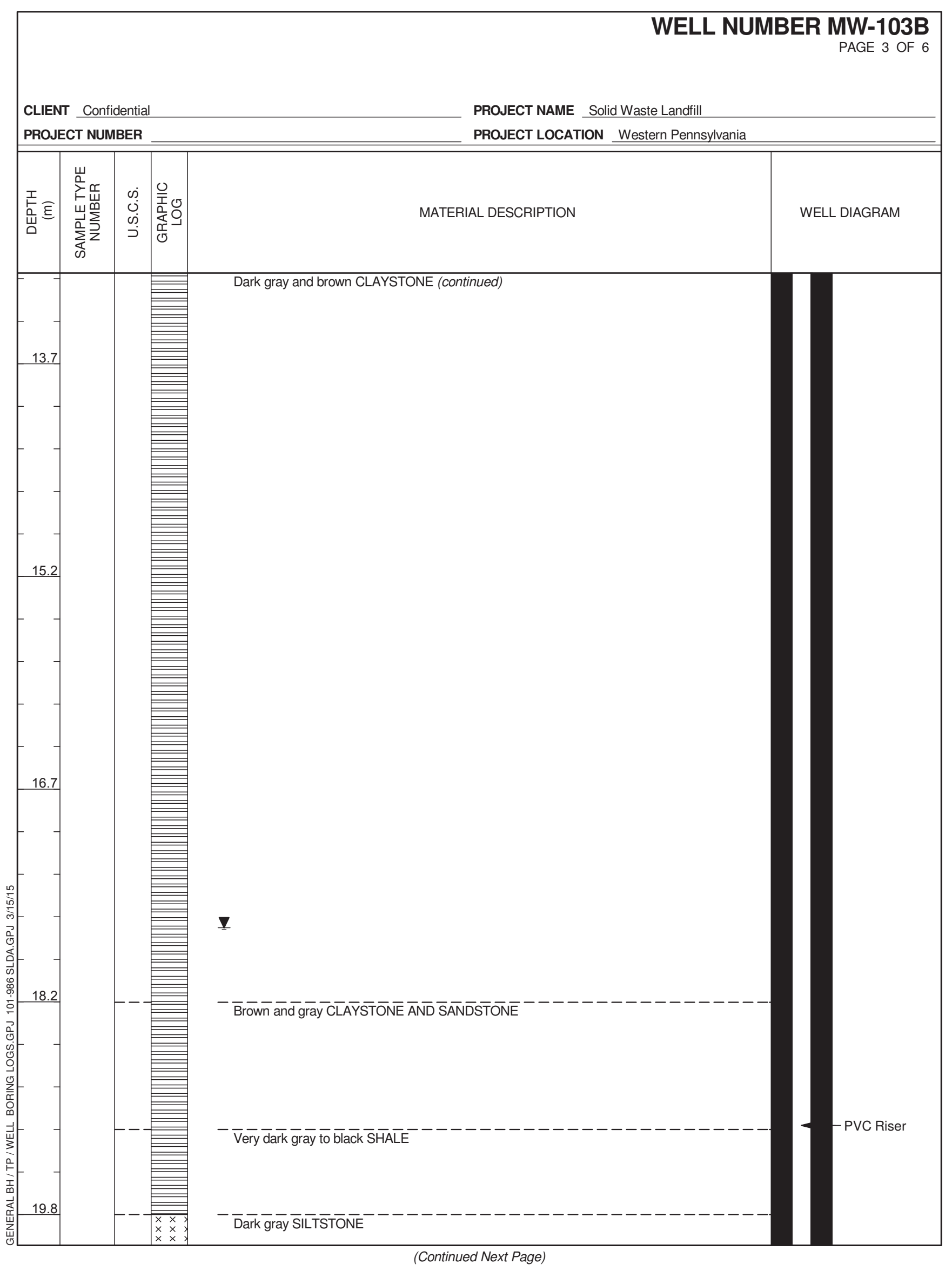




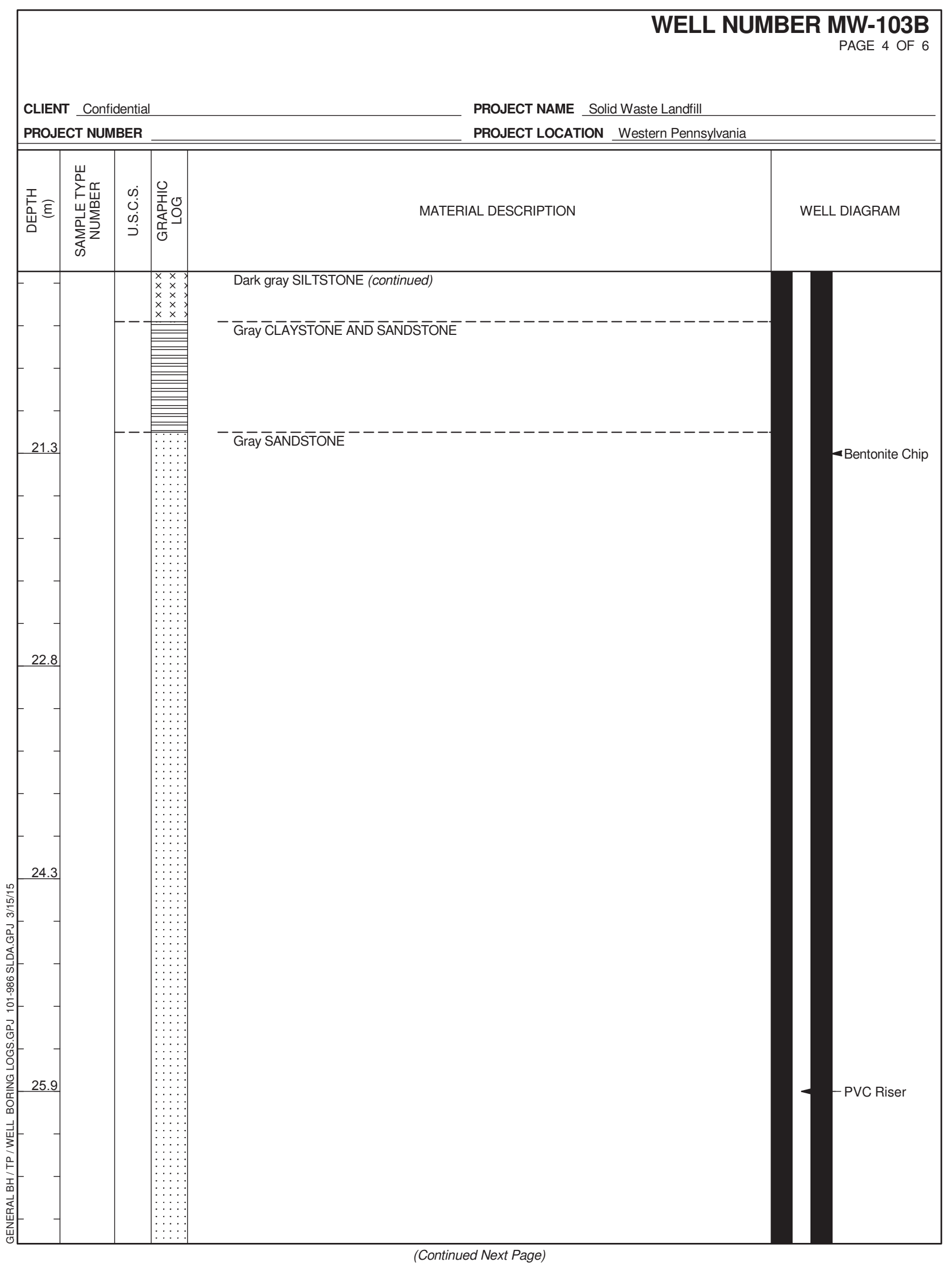




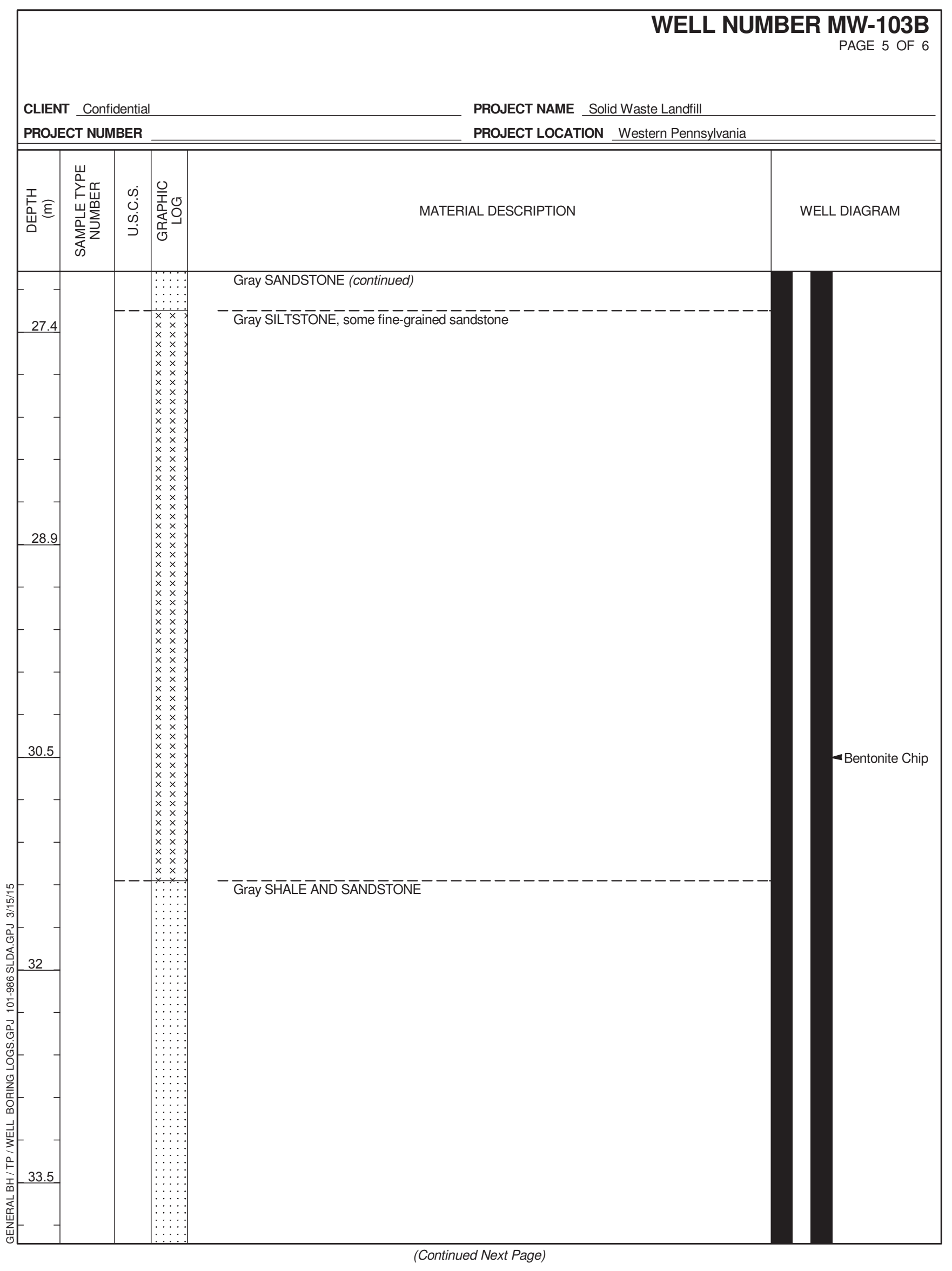




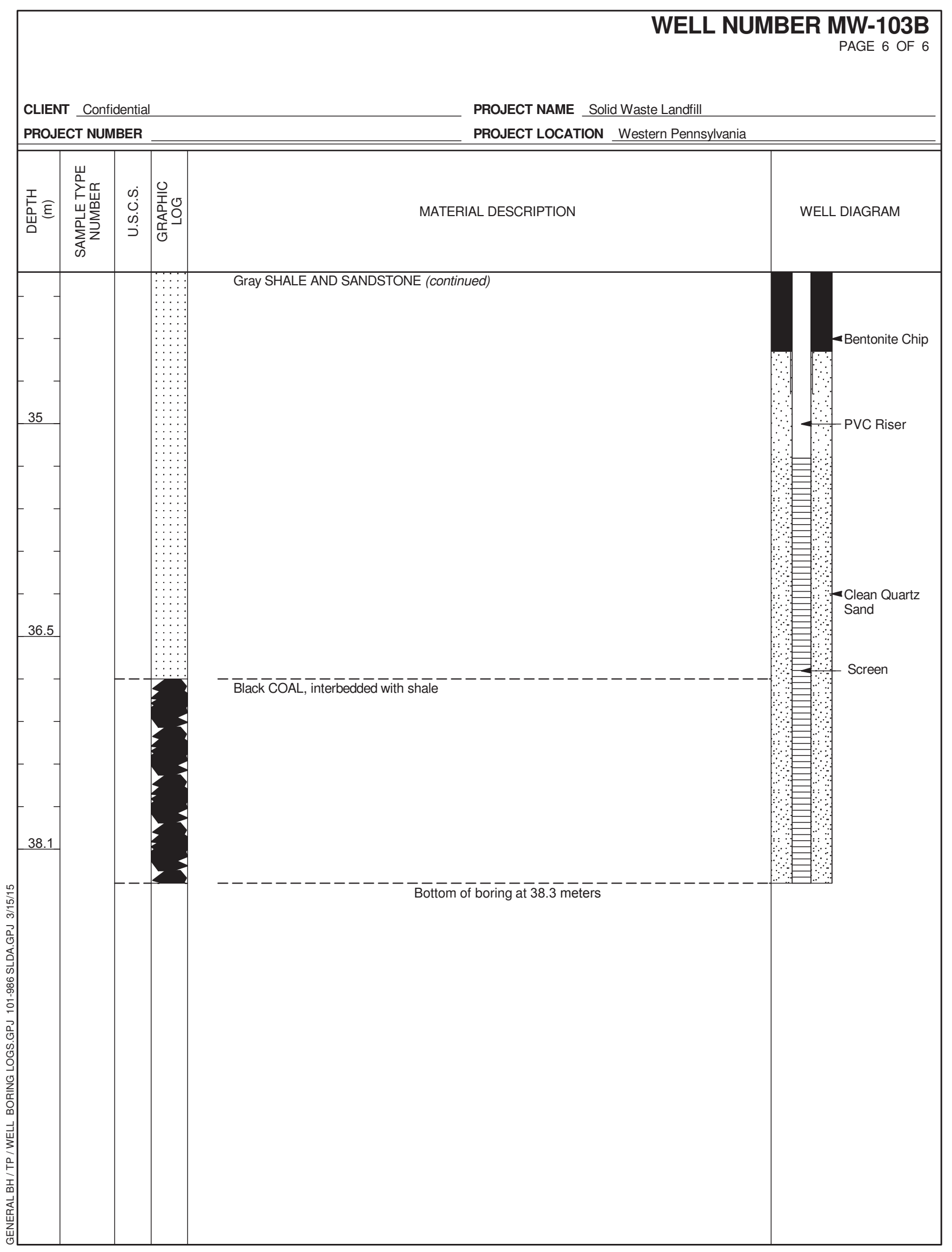




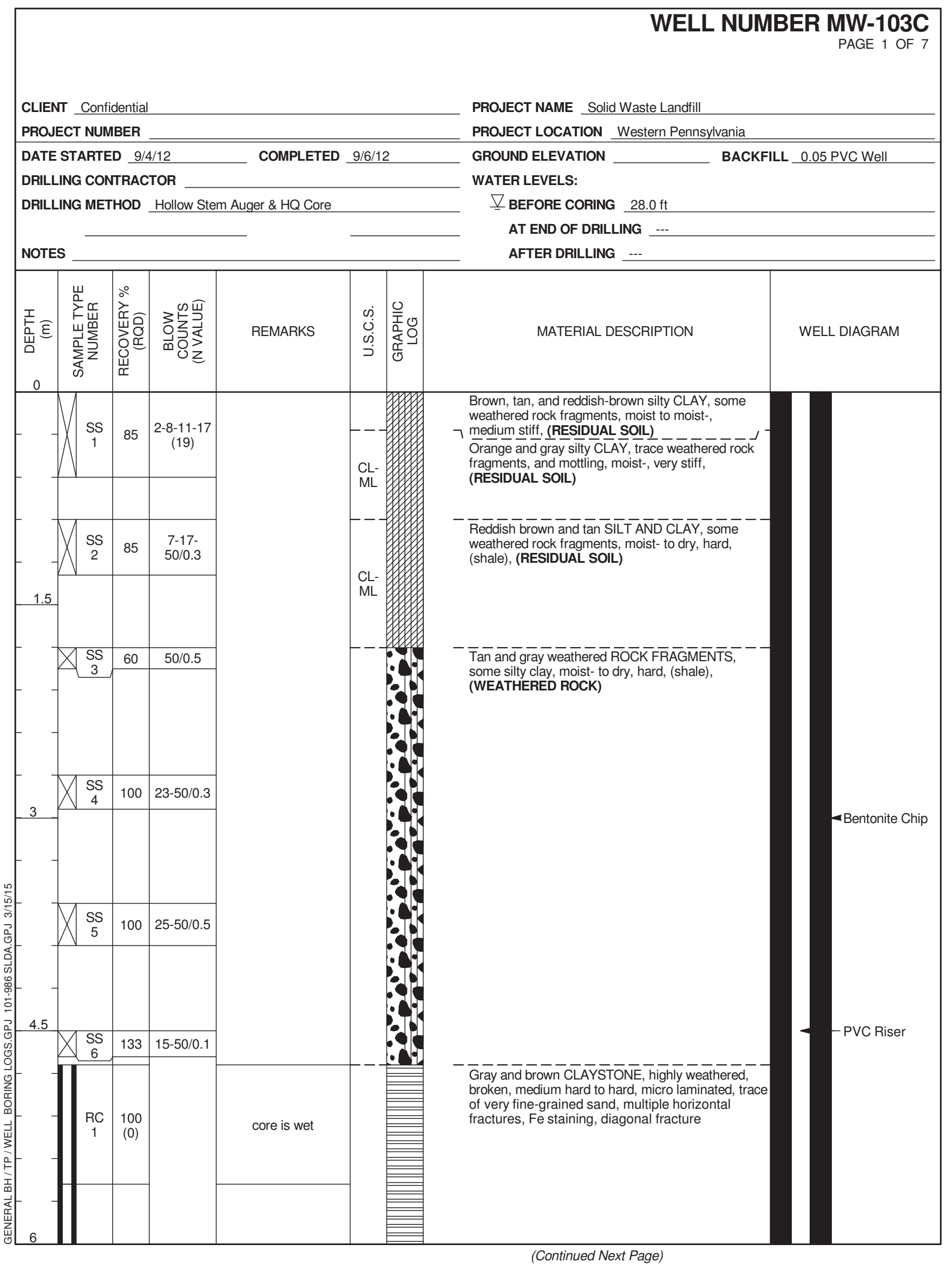

Figure B-8: MW-103C Boring Log 


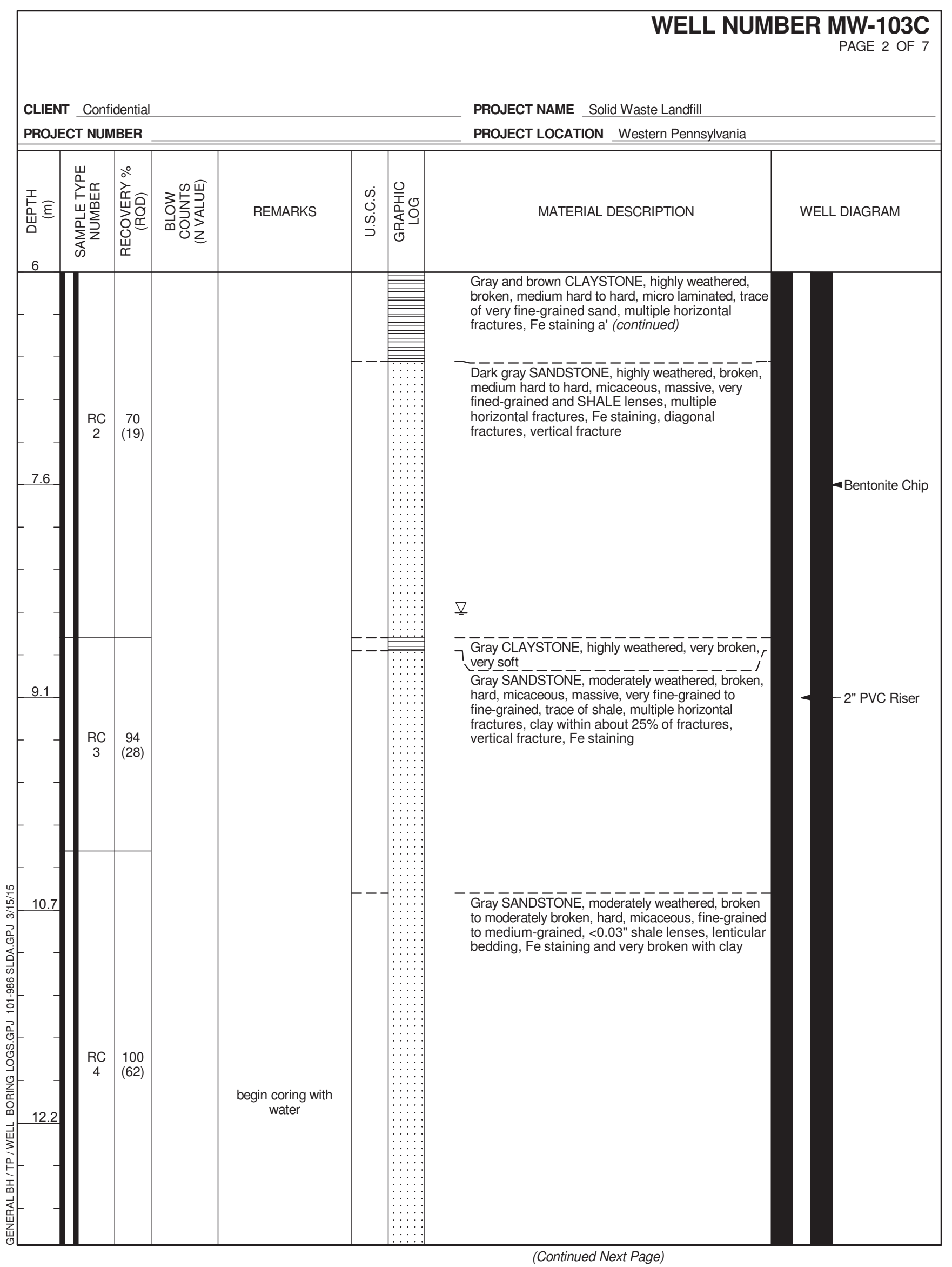




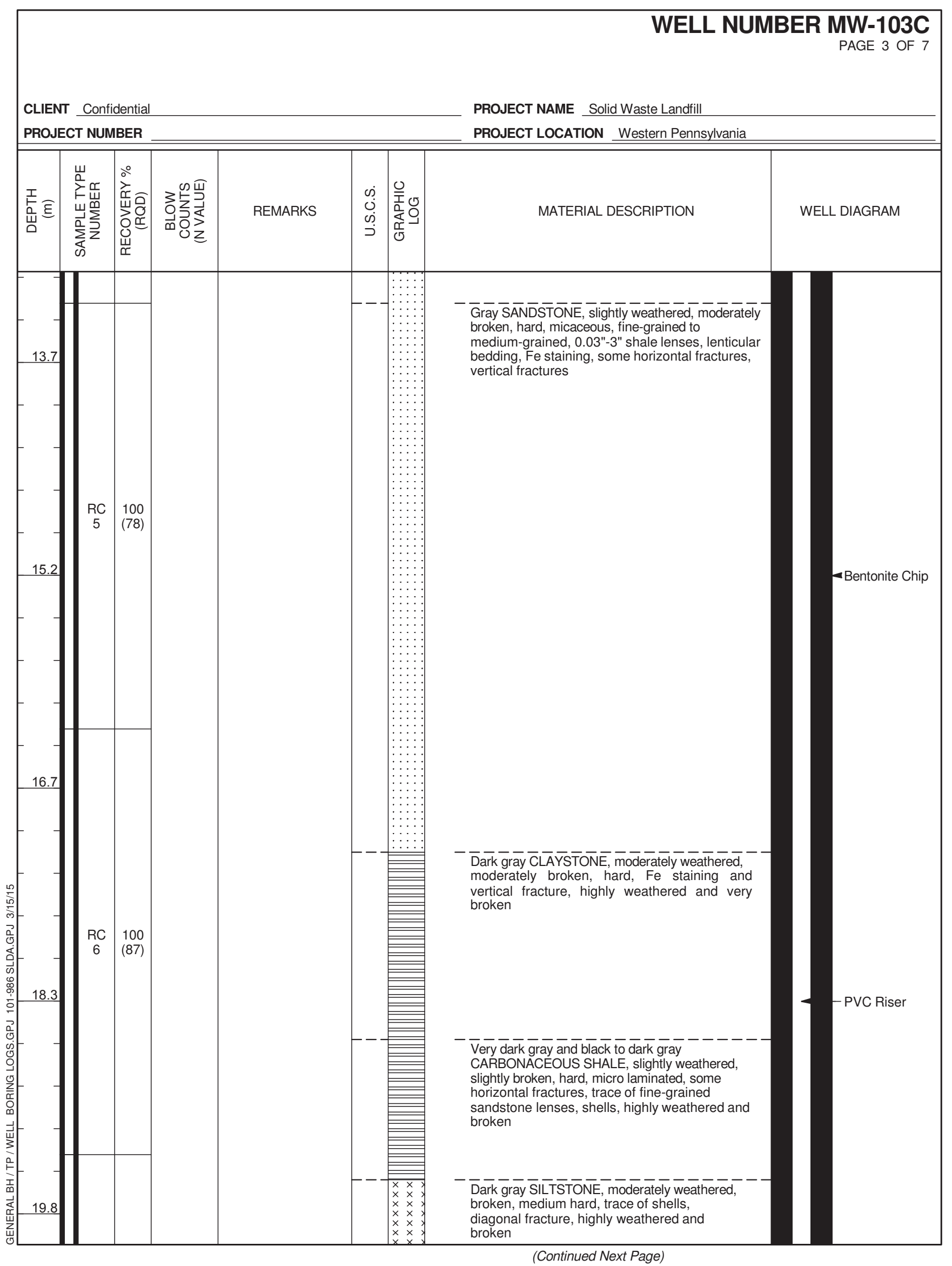




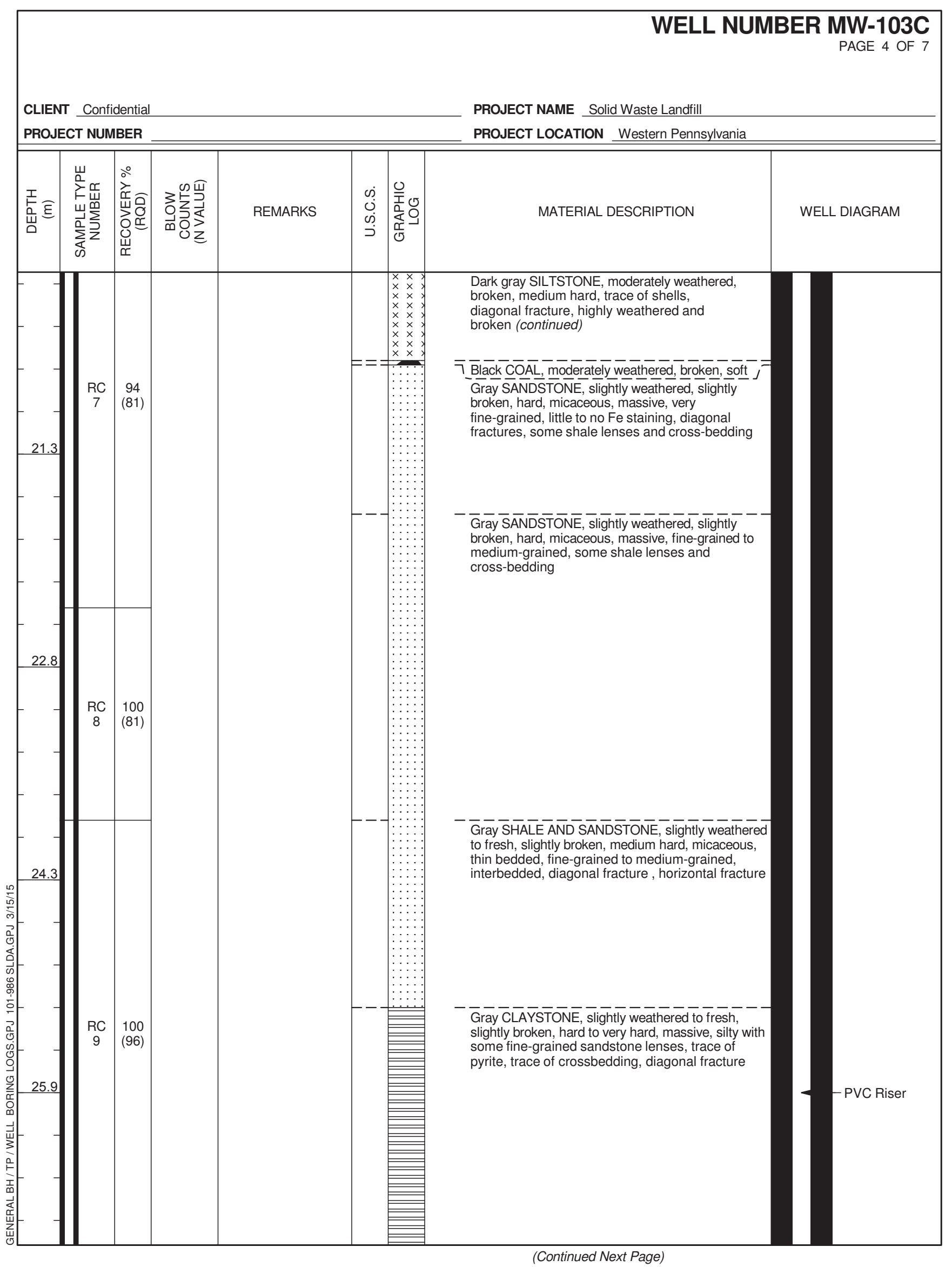




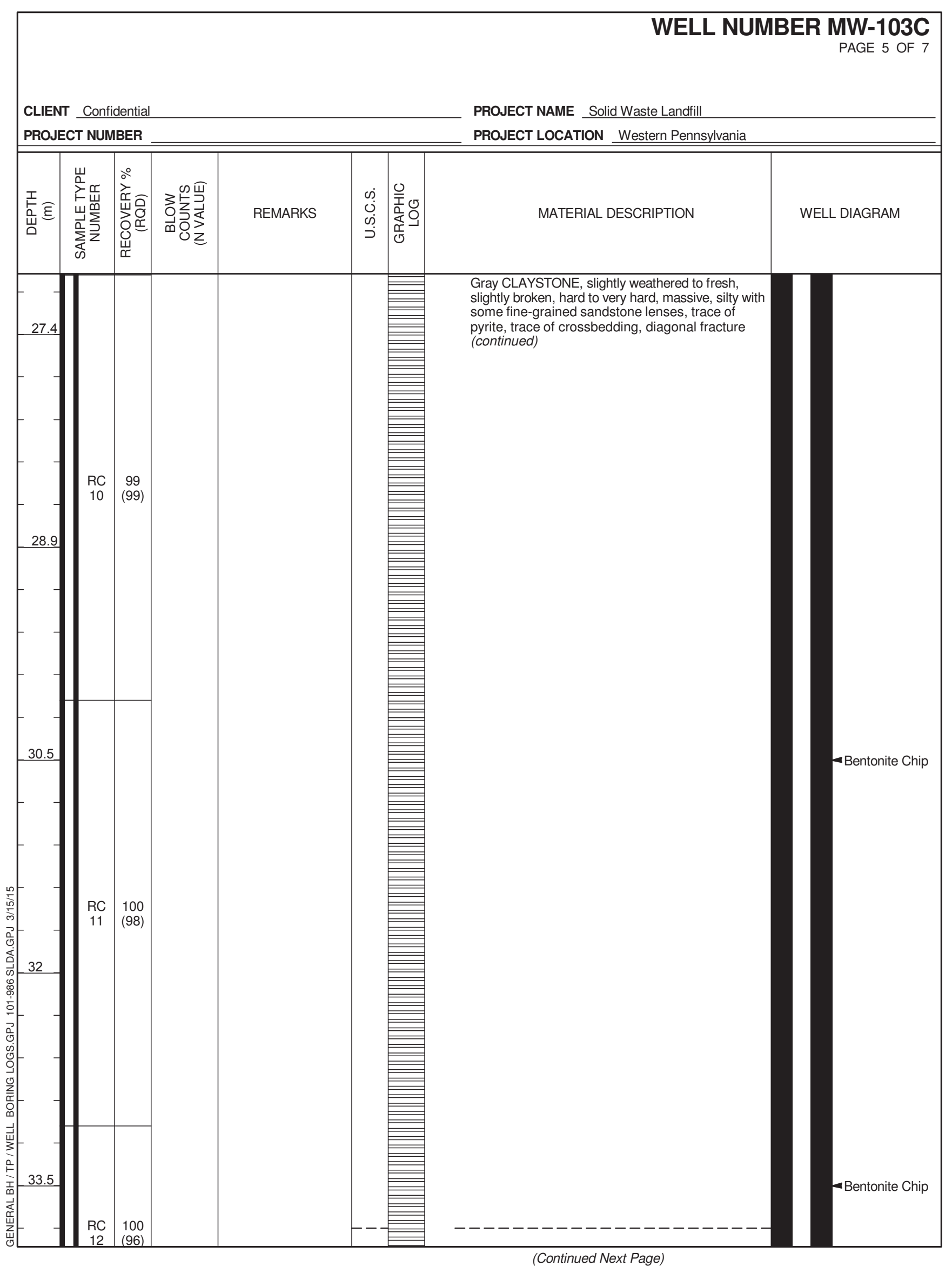




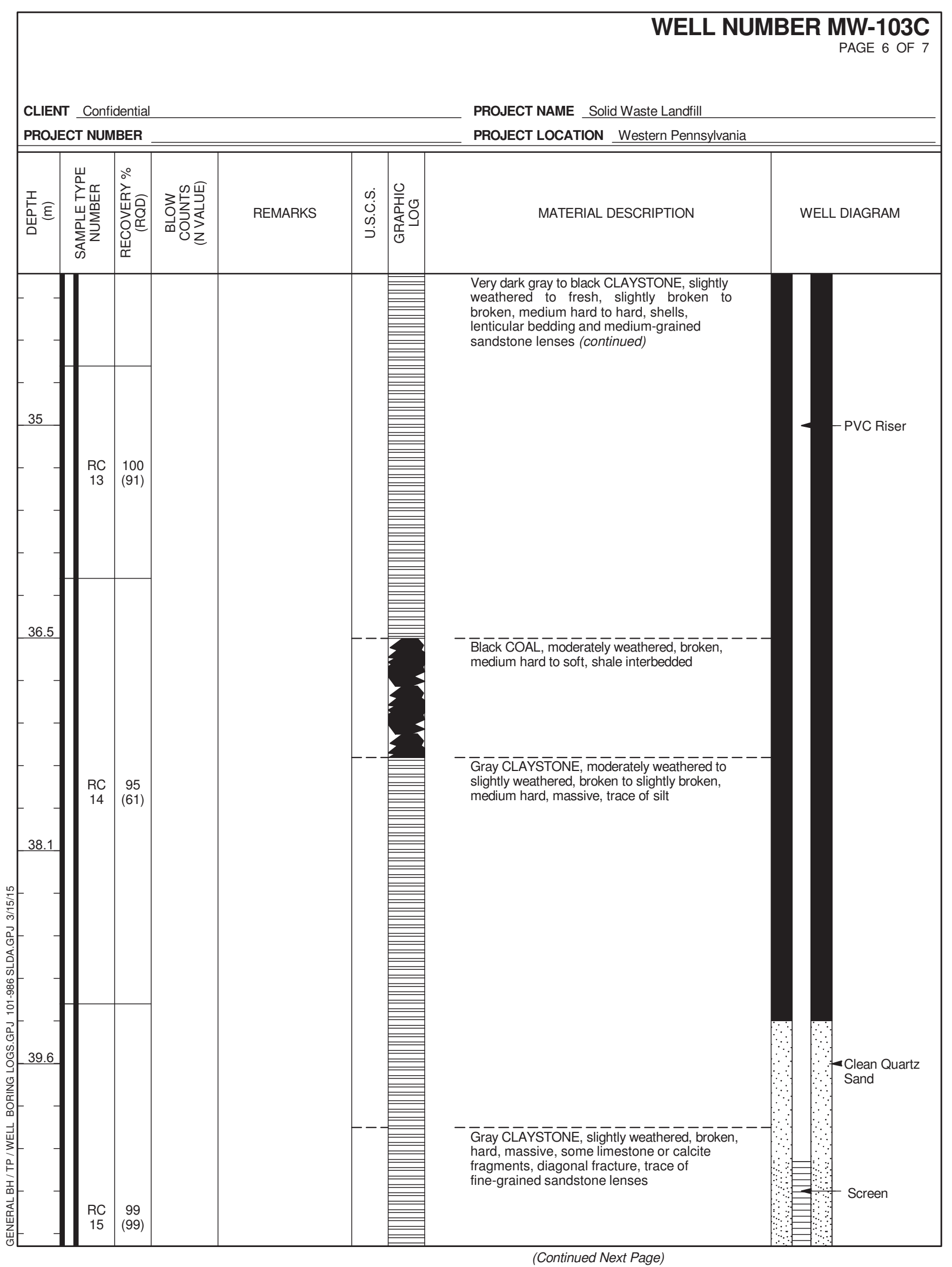




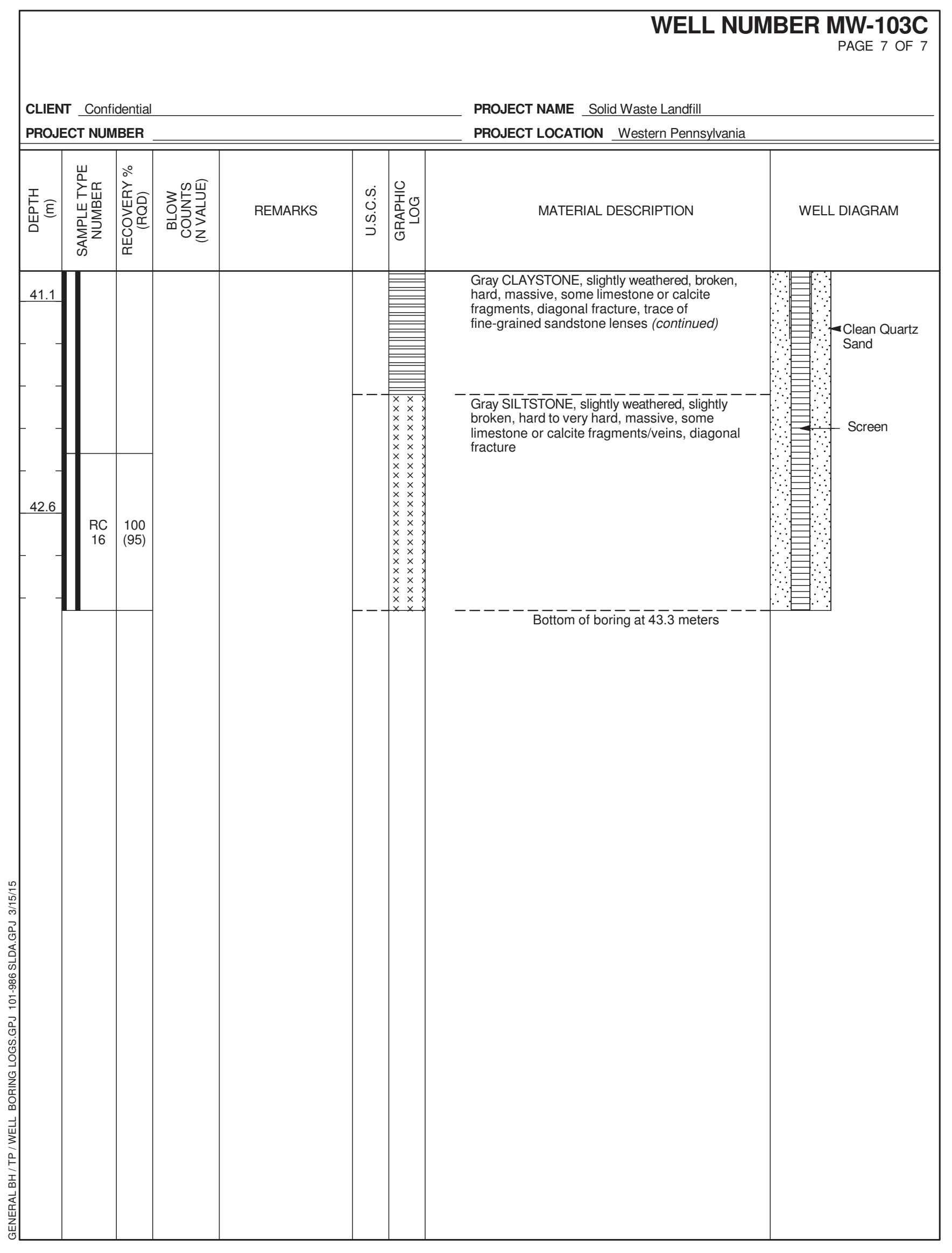


WELL NUMBER MW-105

PAGE 1 OF 2

CLIENT Confidential

PROJECT NUMBER

DATE STARTED 9/20/12

DRILLING CONTRACTOR

DRILLING METHOD Hollow Stem Auger \& HQ Core

NOTES

(10)

PROJECT NAME Solid Waste Landfill PROJECT LOCATION Western Pennsylvania

GROUND ELEVATION BACKFILL 0.05 PVC Well

WATER LEVELS:

$\underline{\nabla}$ BEFORE CORING $23.0 \mathrm{ft}$

AT END OF DRILLING

AFTER DRILLING

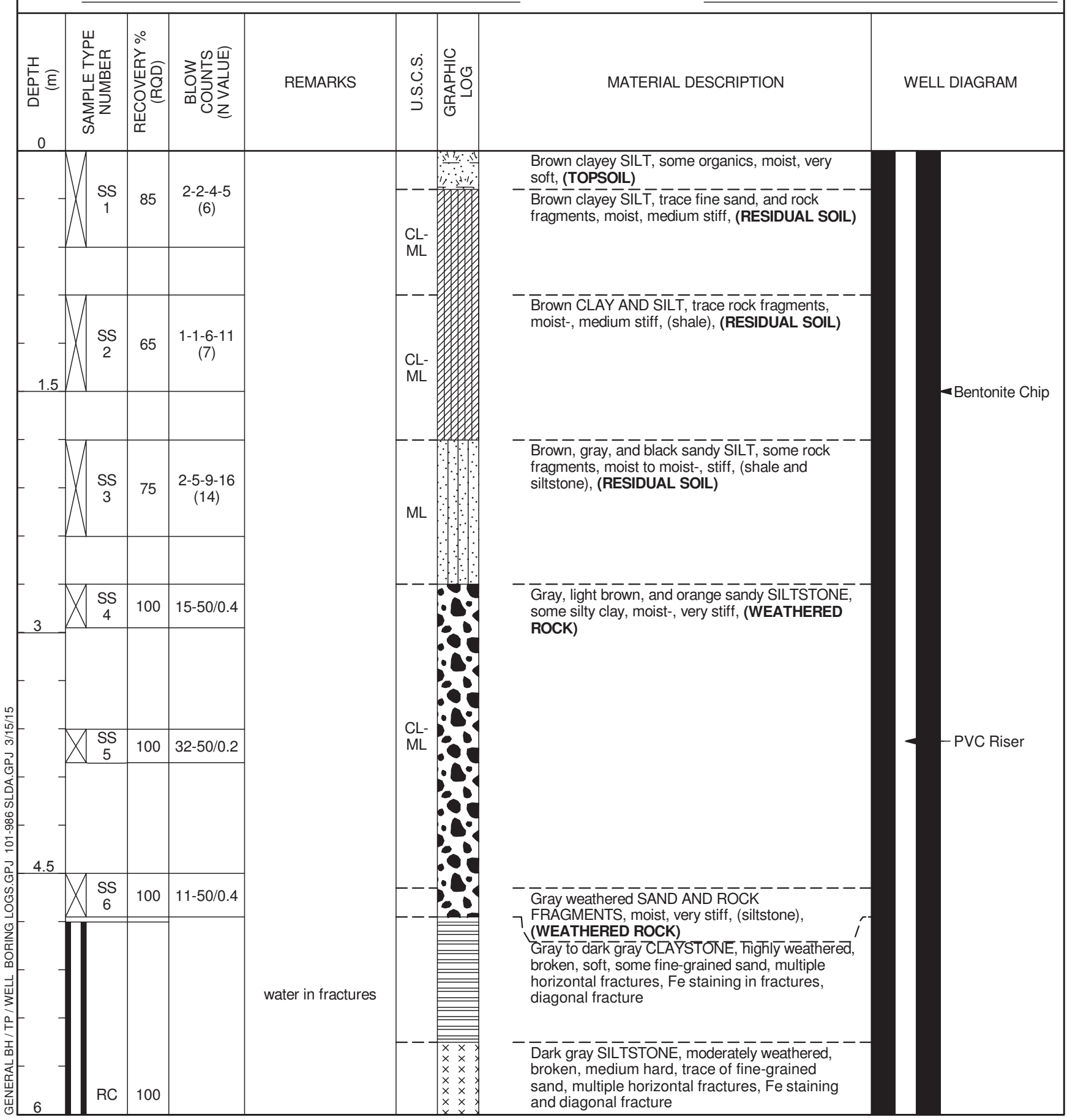

(Continued Next Page)

Figure B-9: MW-105 Boring Log 


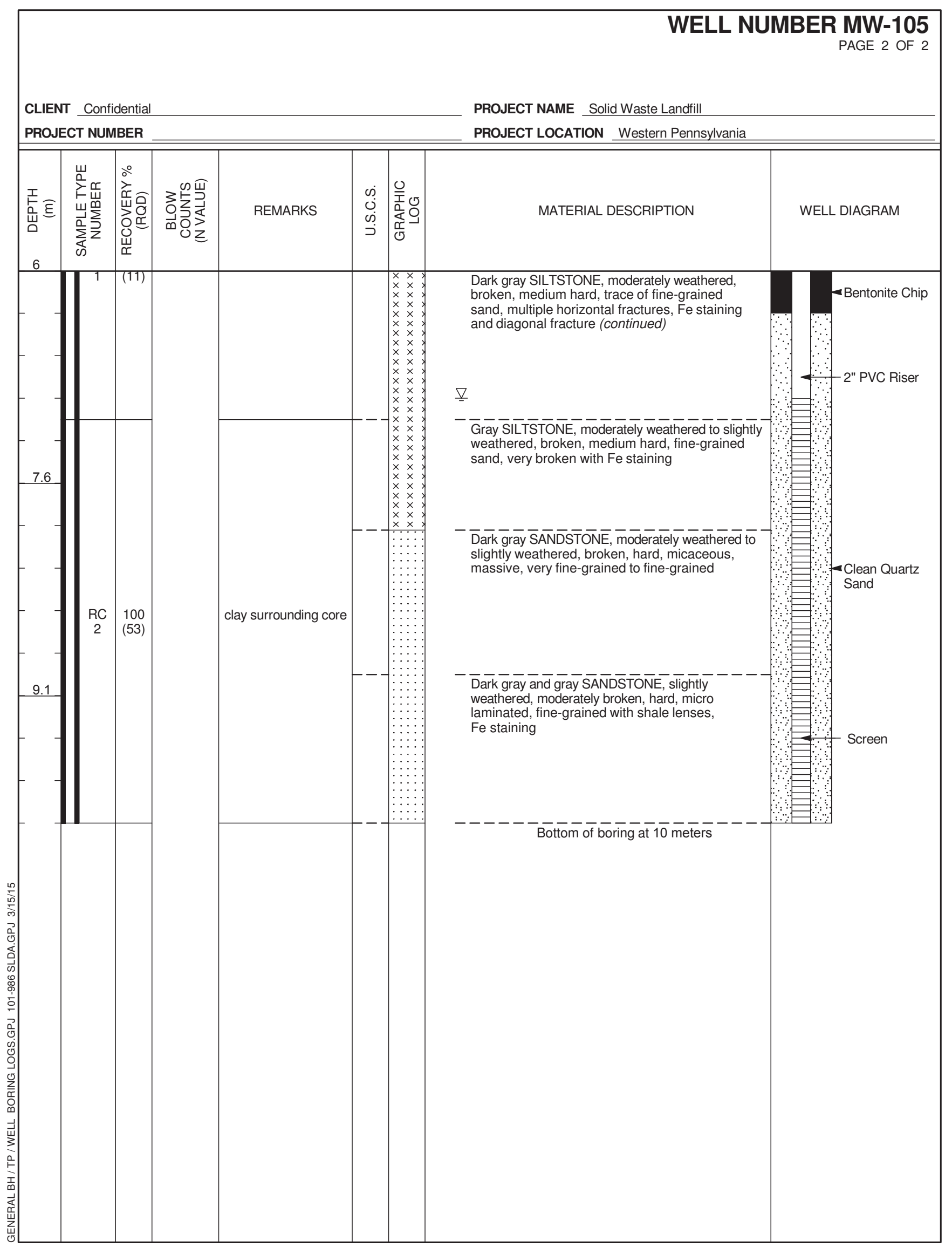




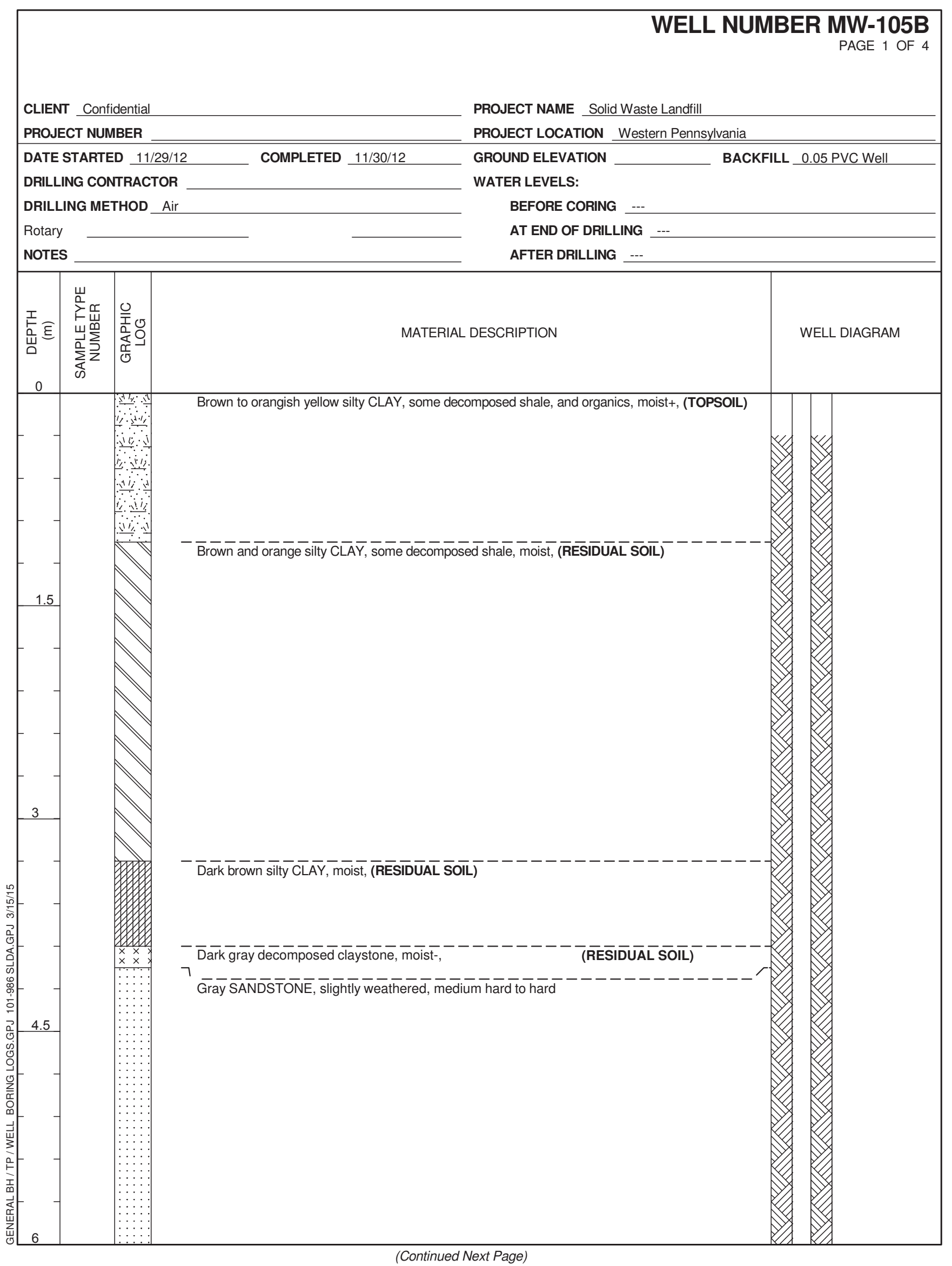

Figure B-10: MW-105B Boring Log 


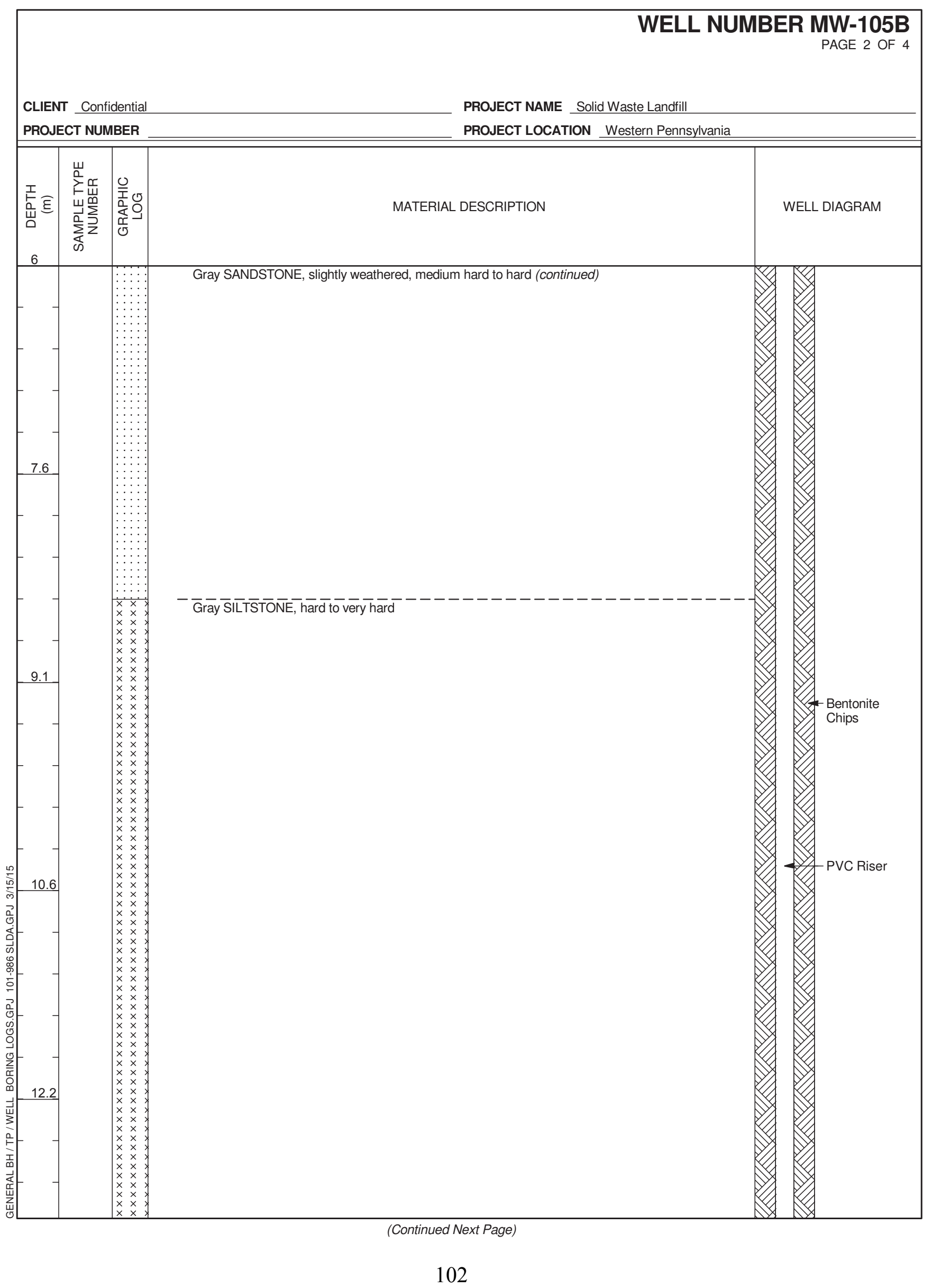




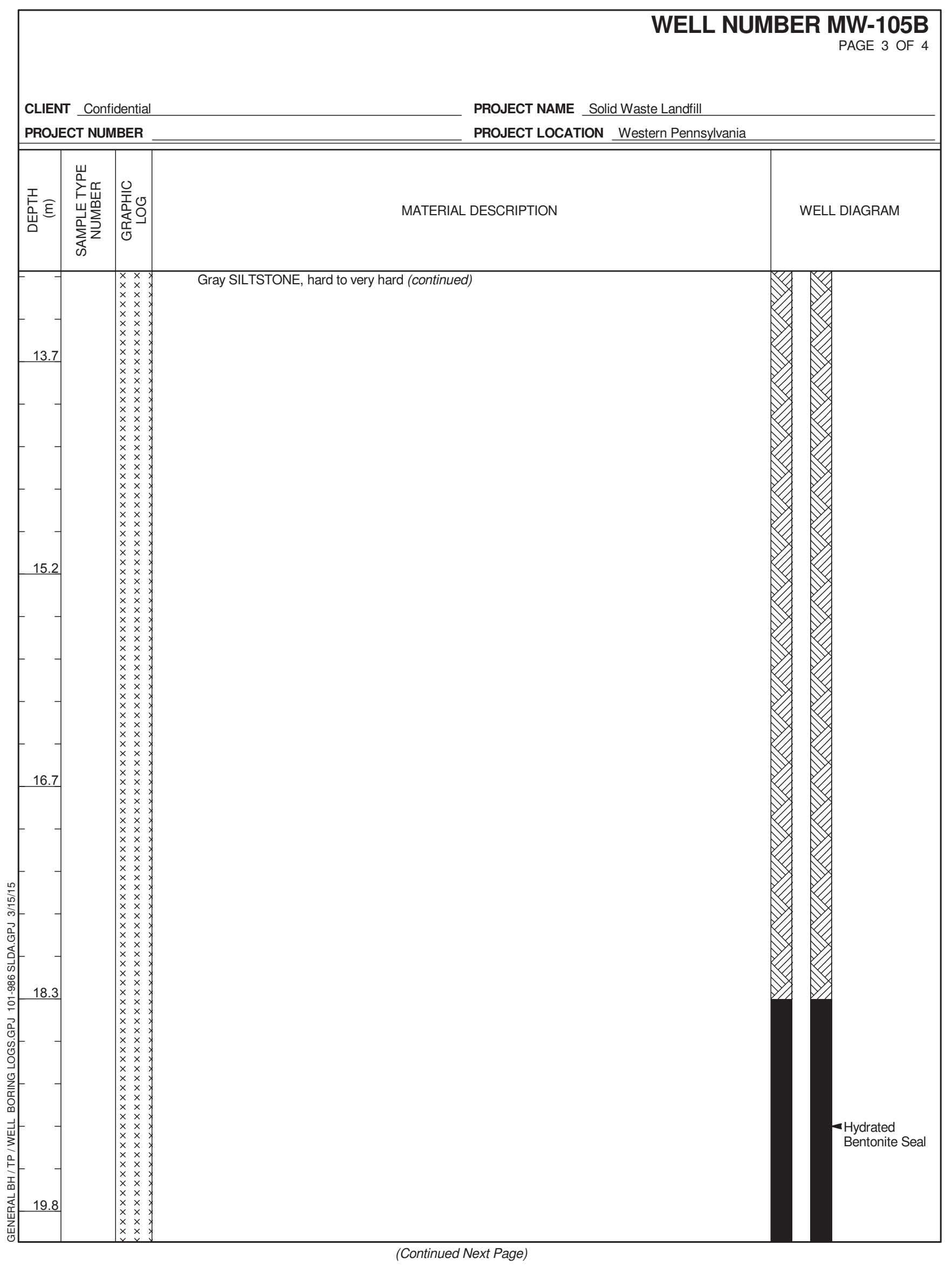




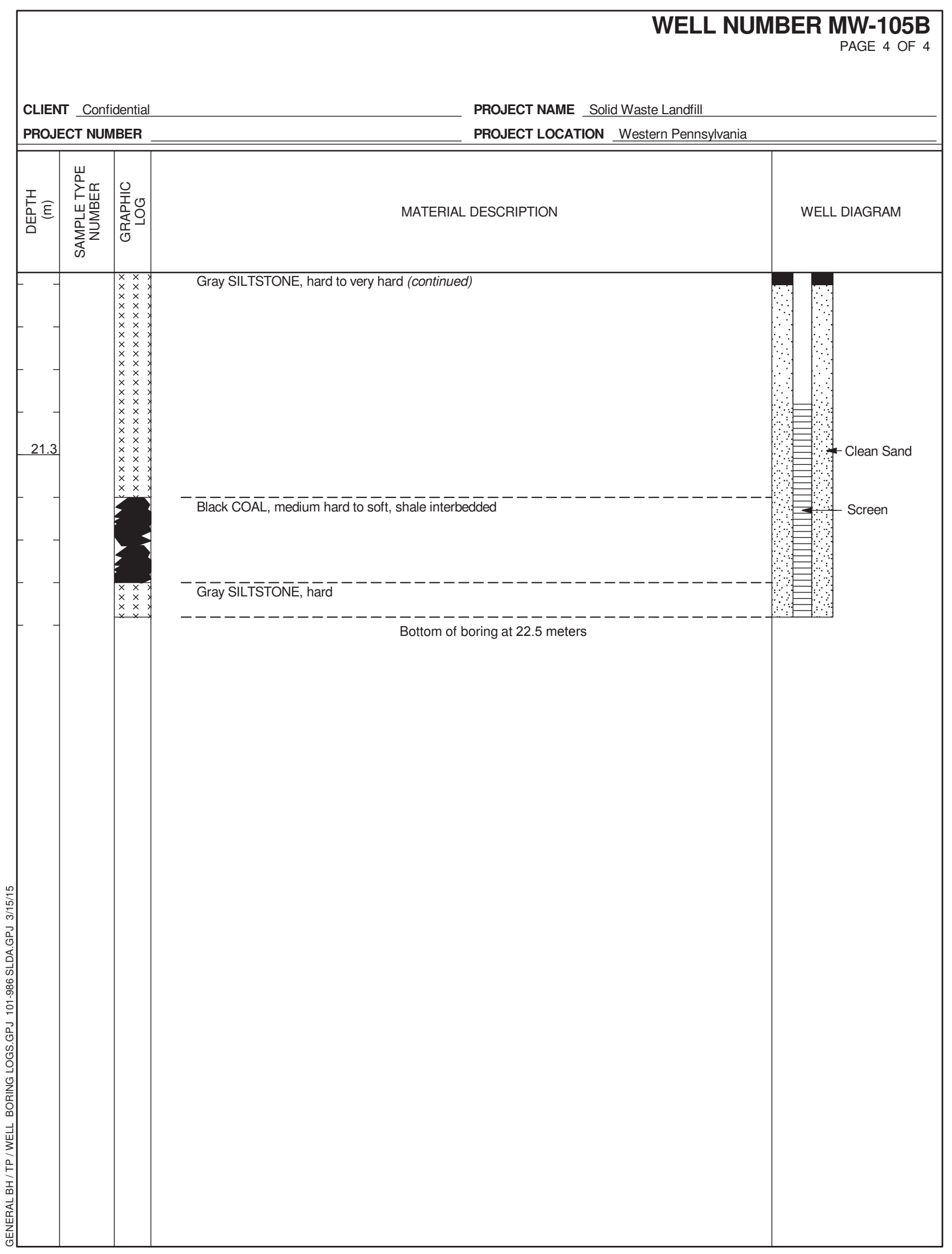




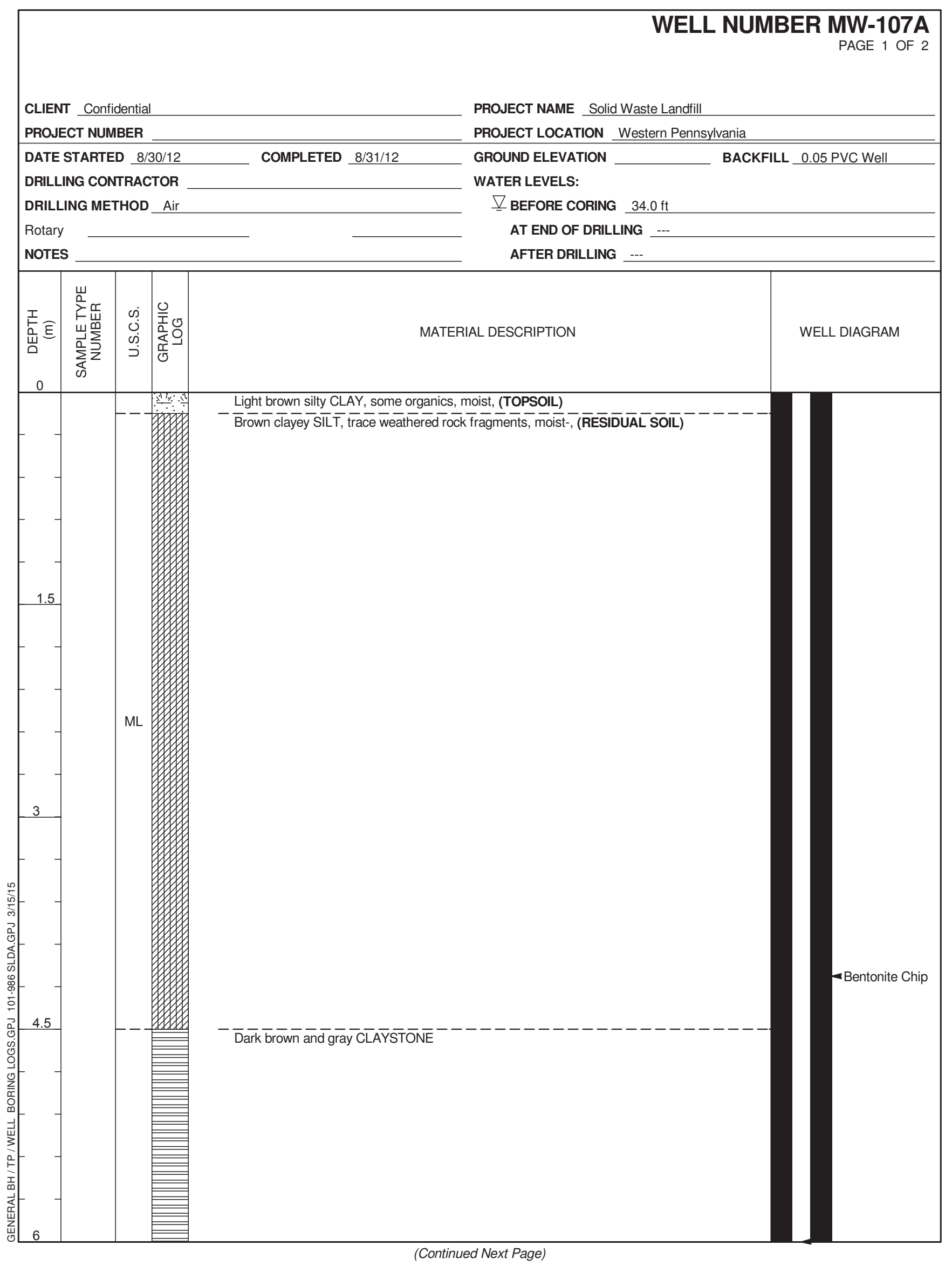

Figure B-11: MW-107A Boring Log 


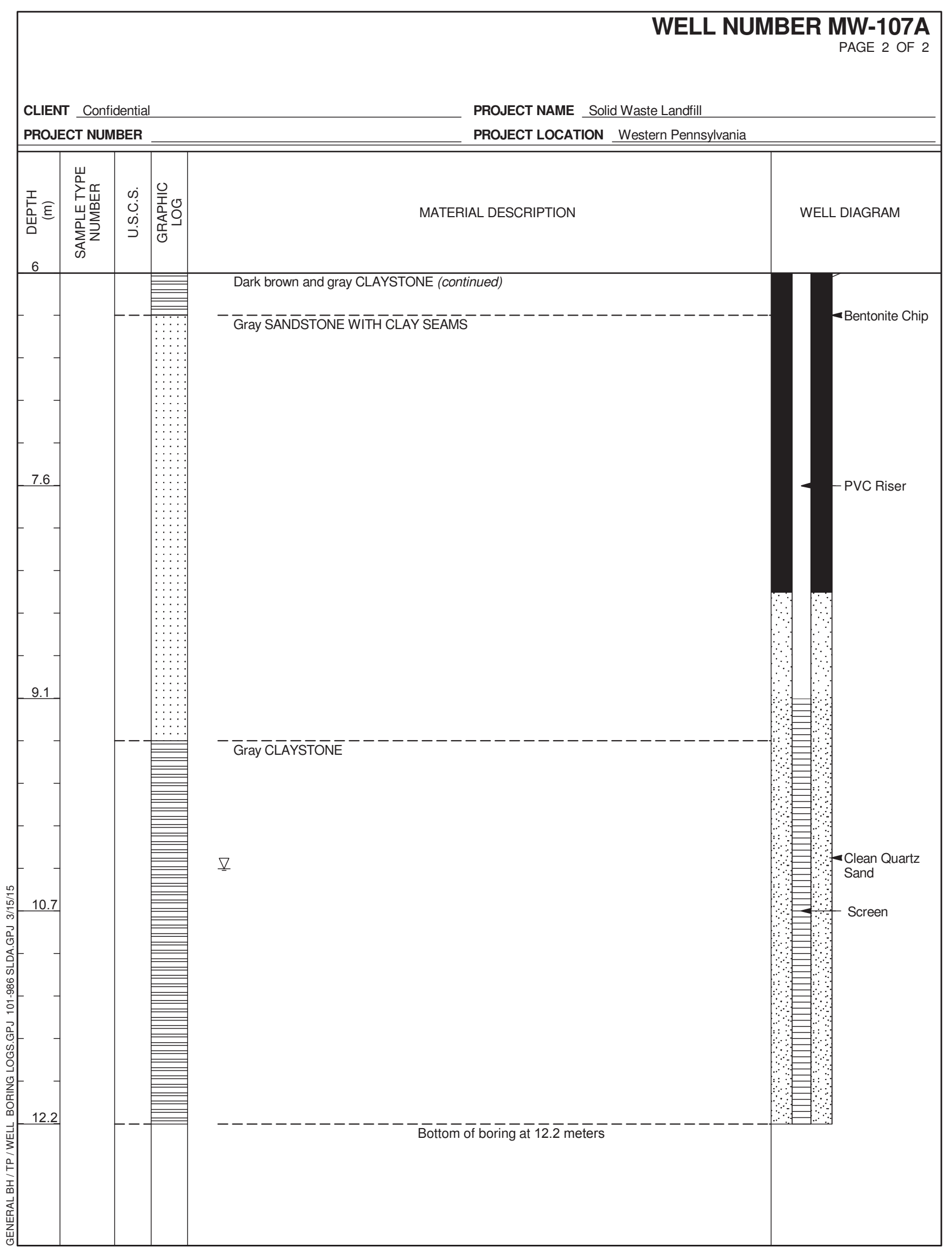




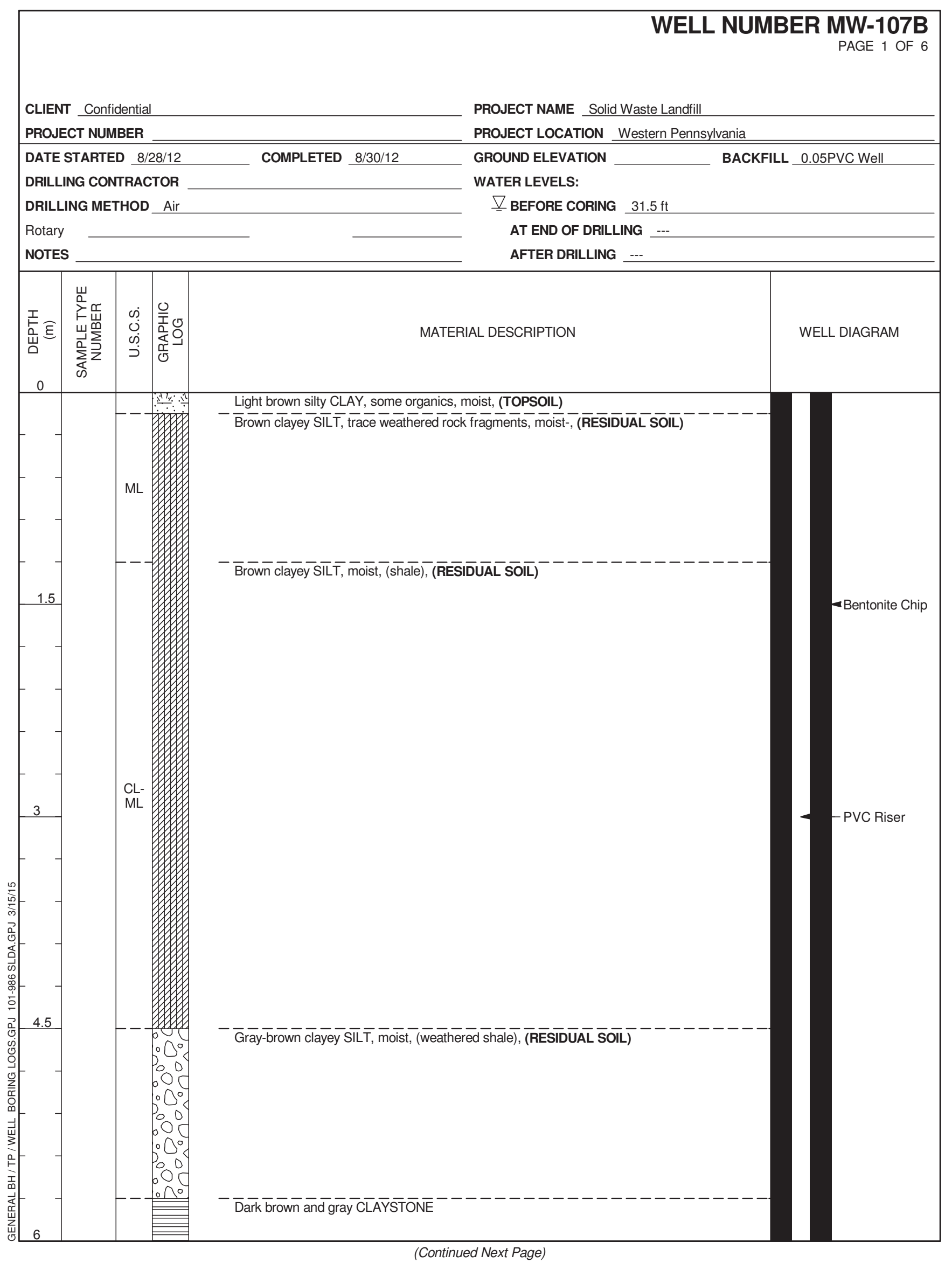

Figure B-12: MW-107B Boring Log 


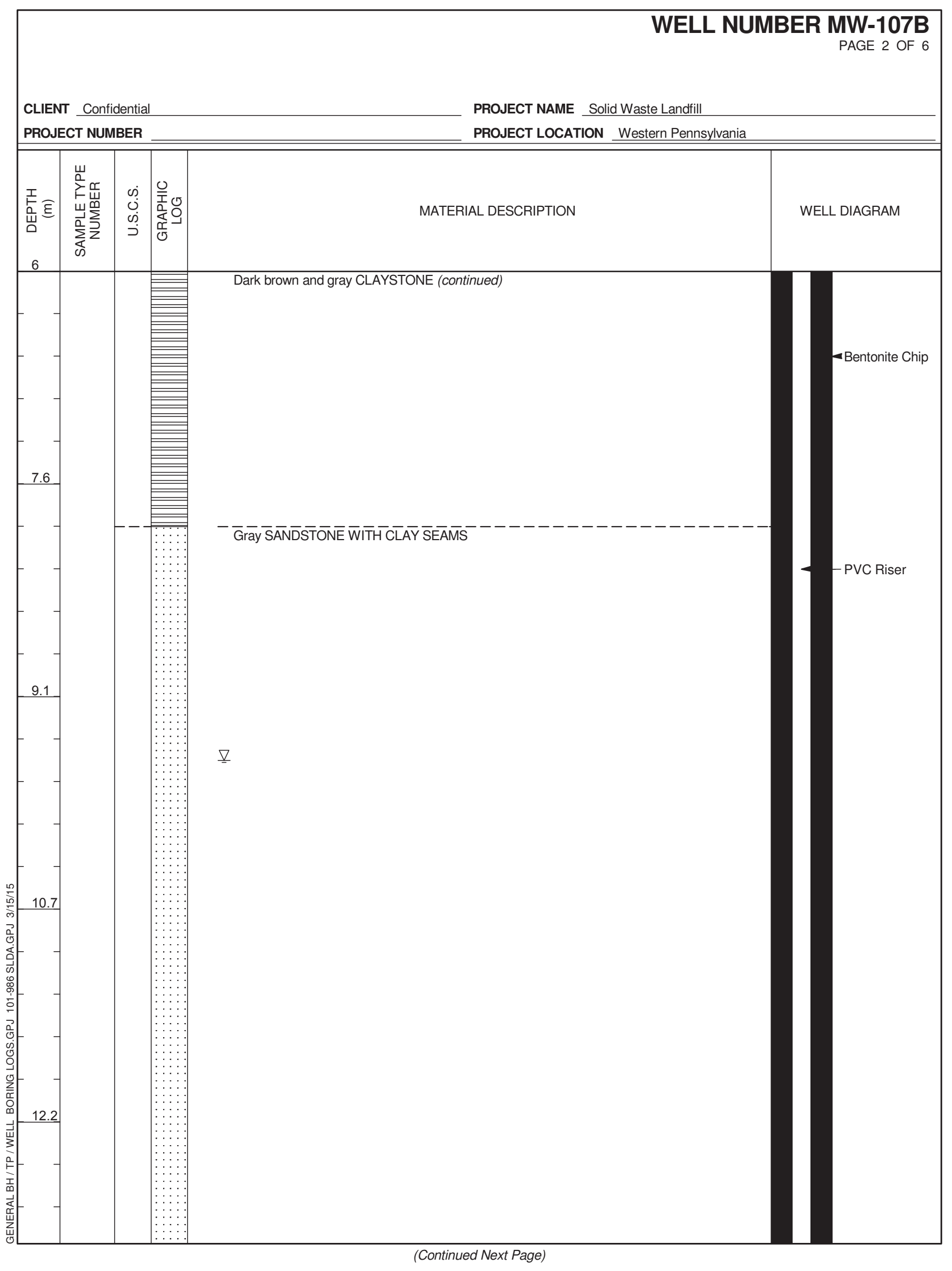




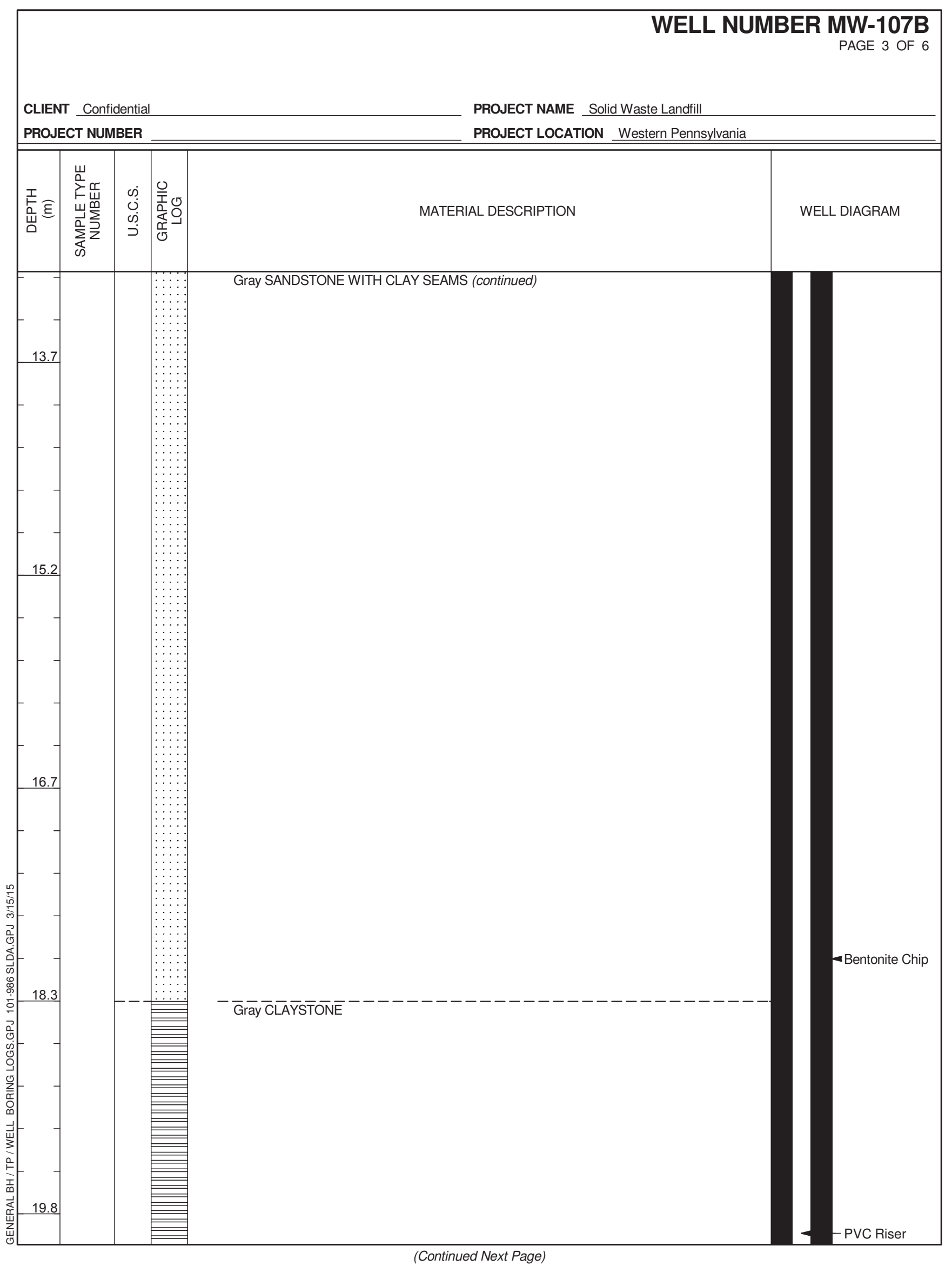




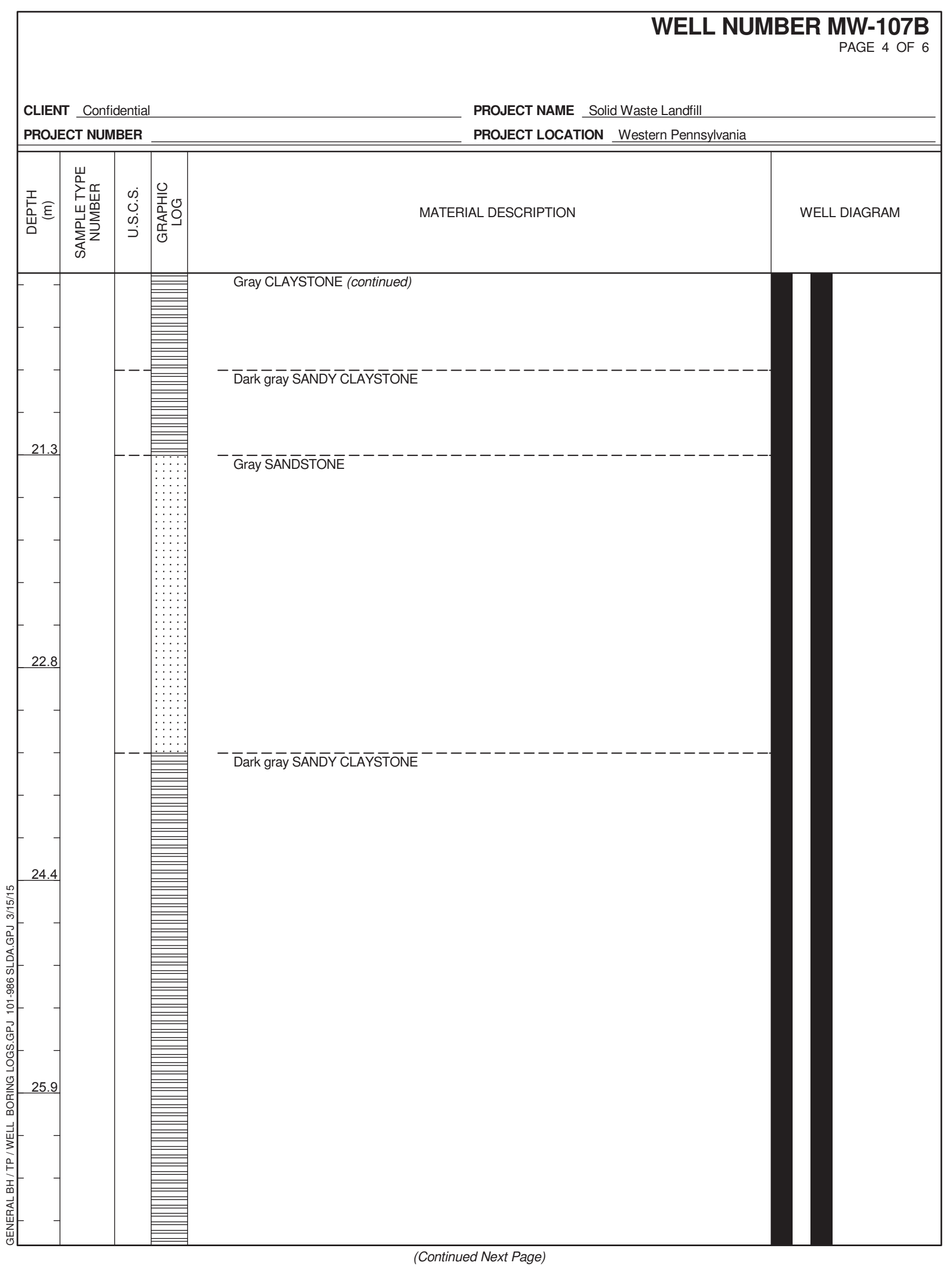




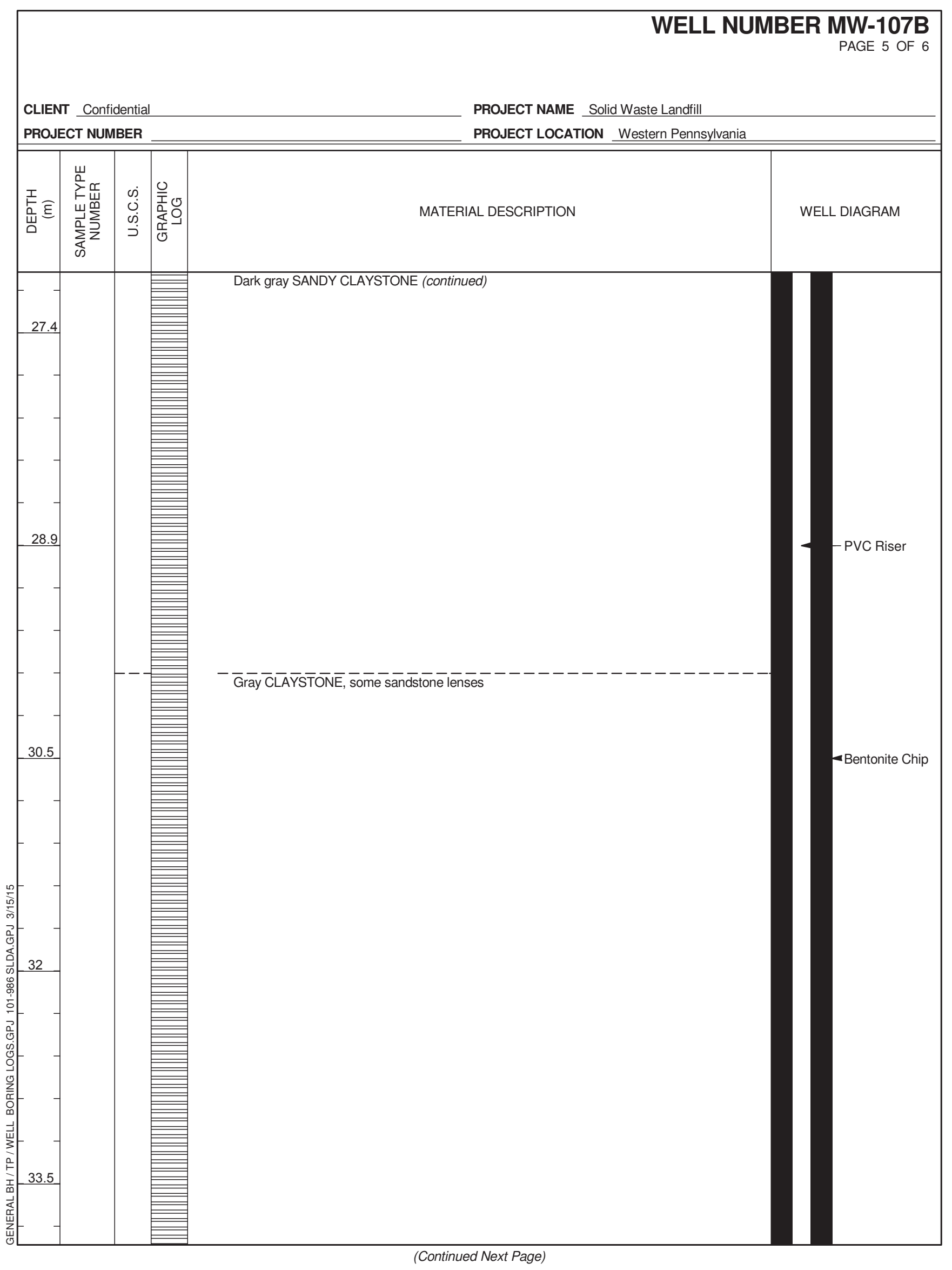




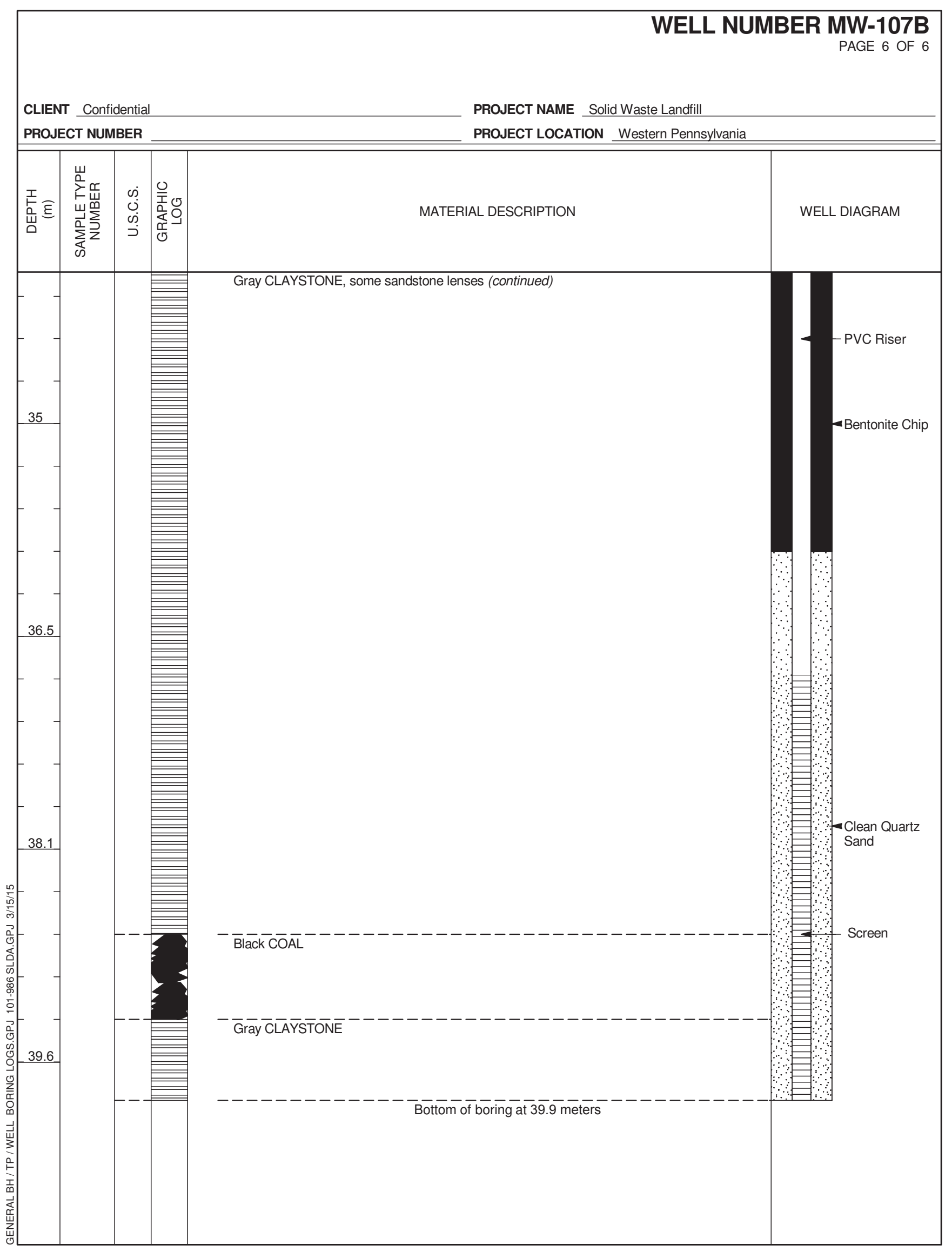




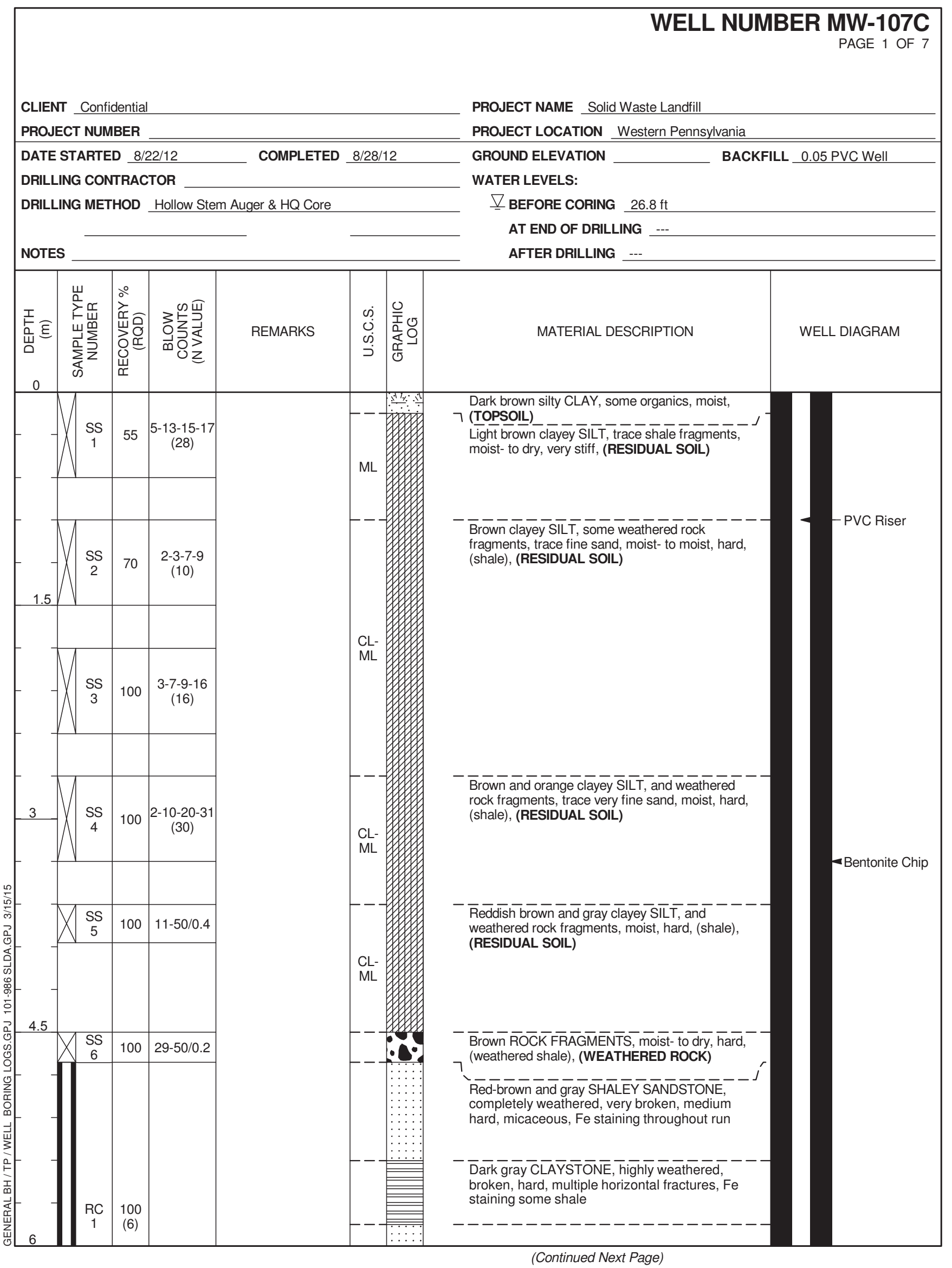

Figure B-13: MW-107C Boring Log

113 


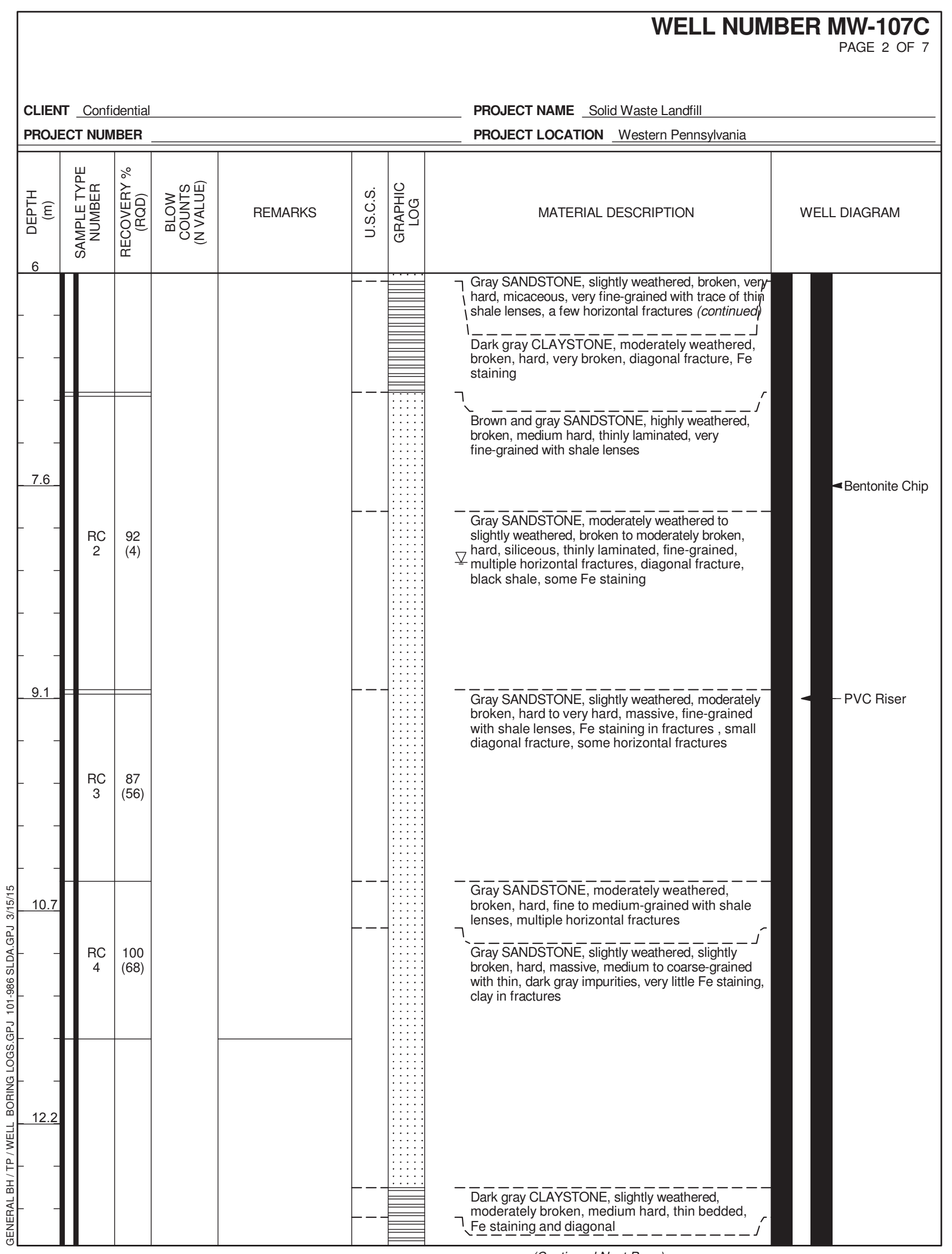

(Continued Next Page) 


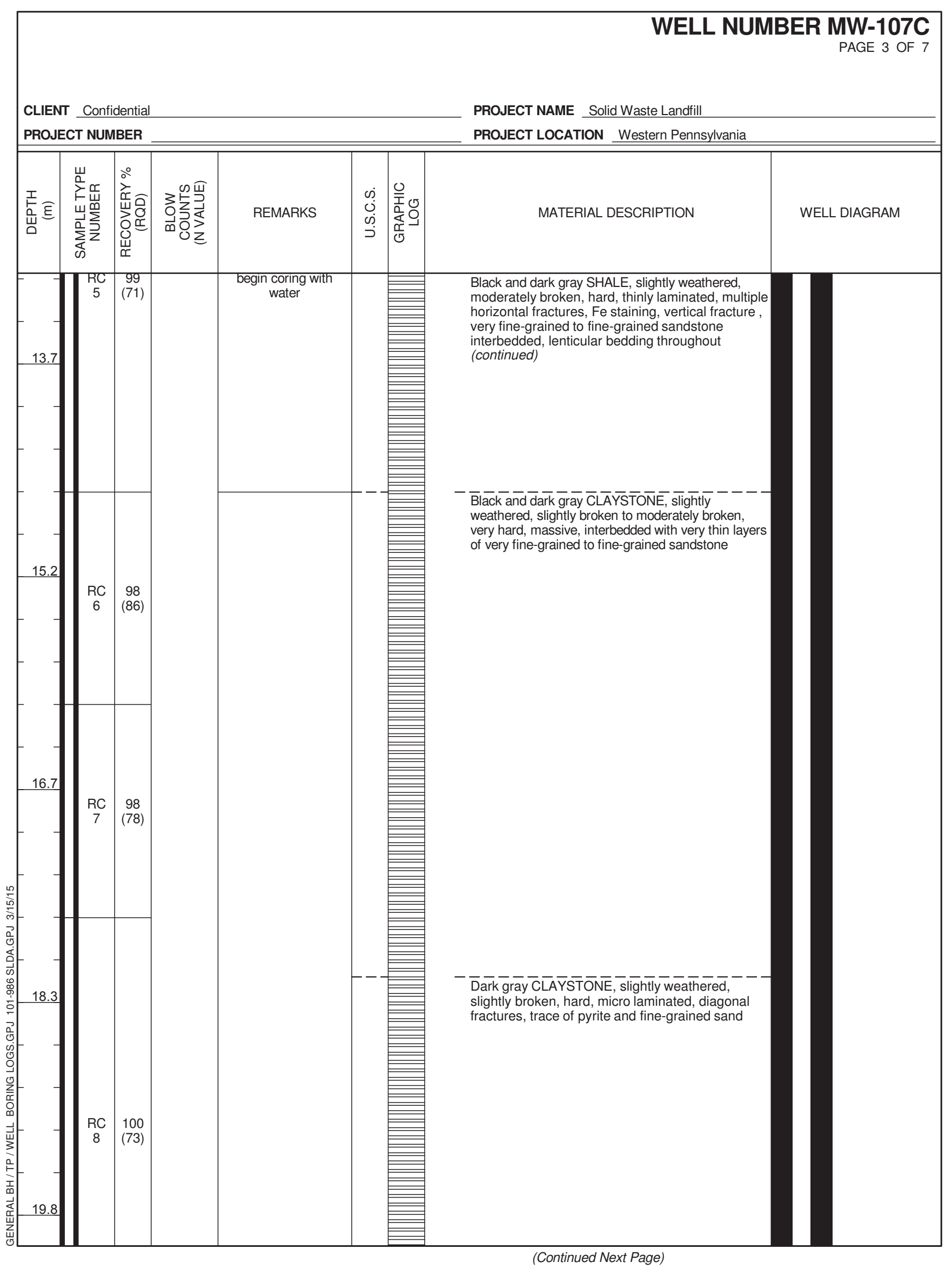




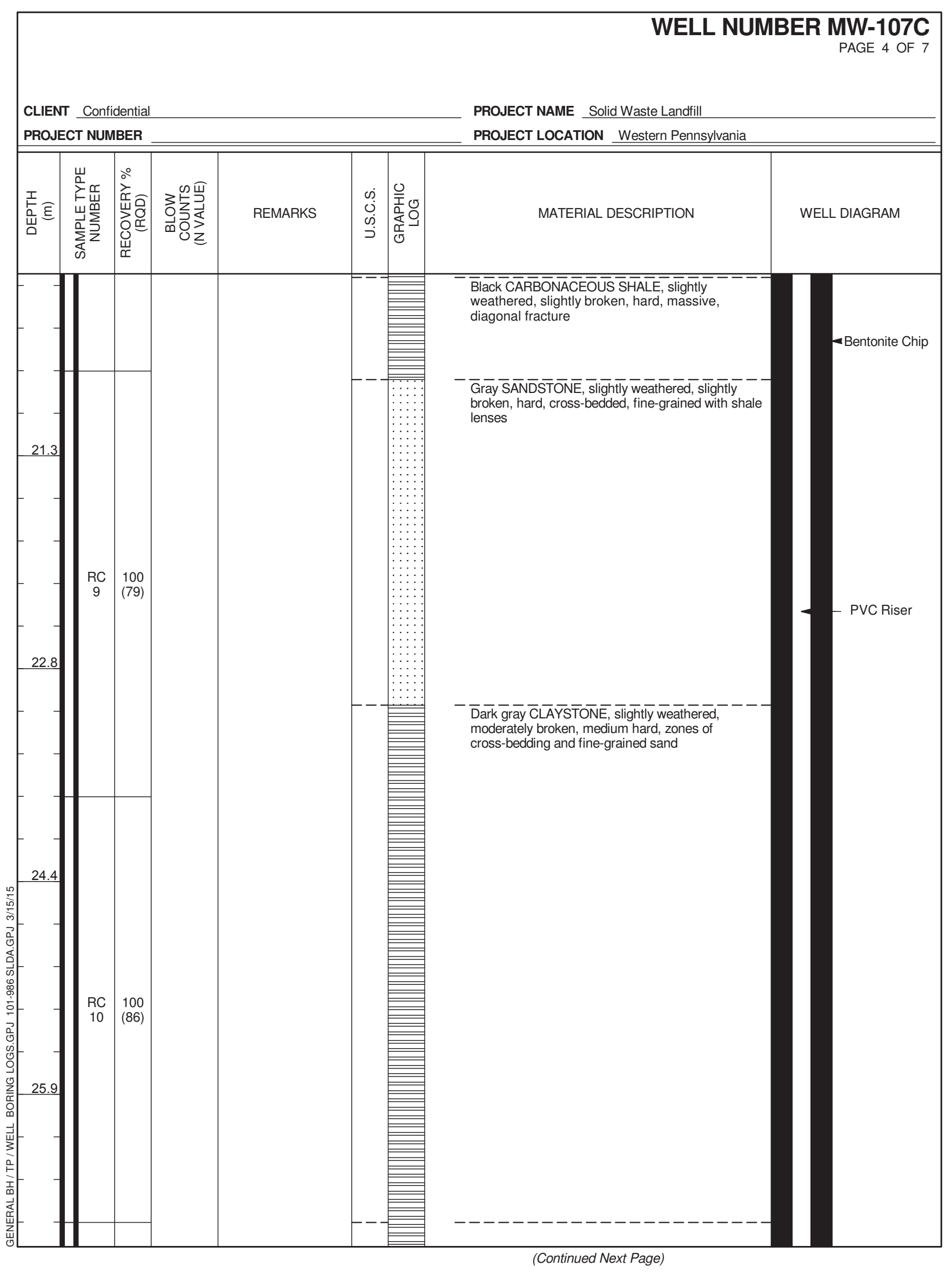




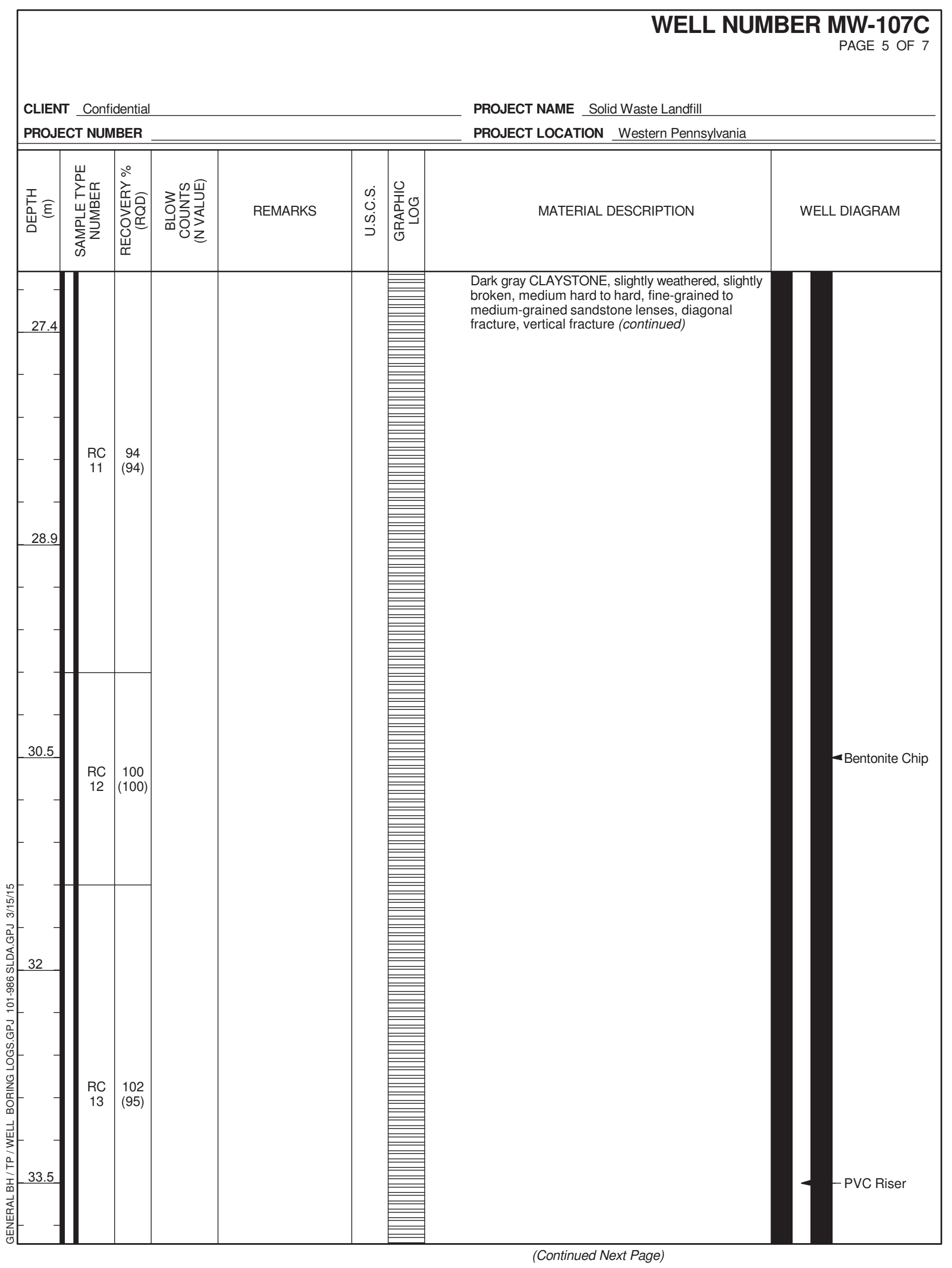




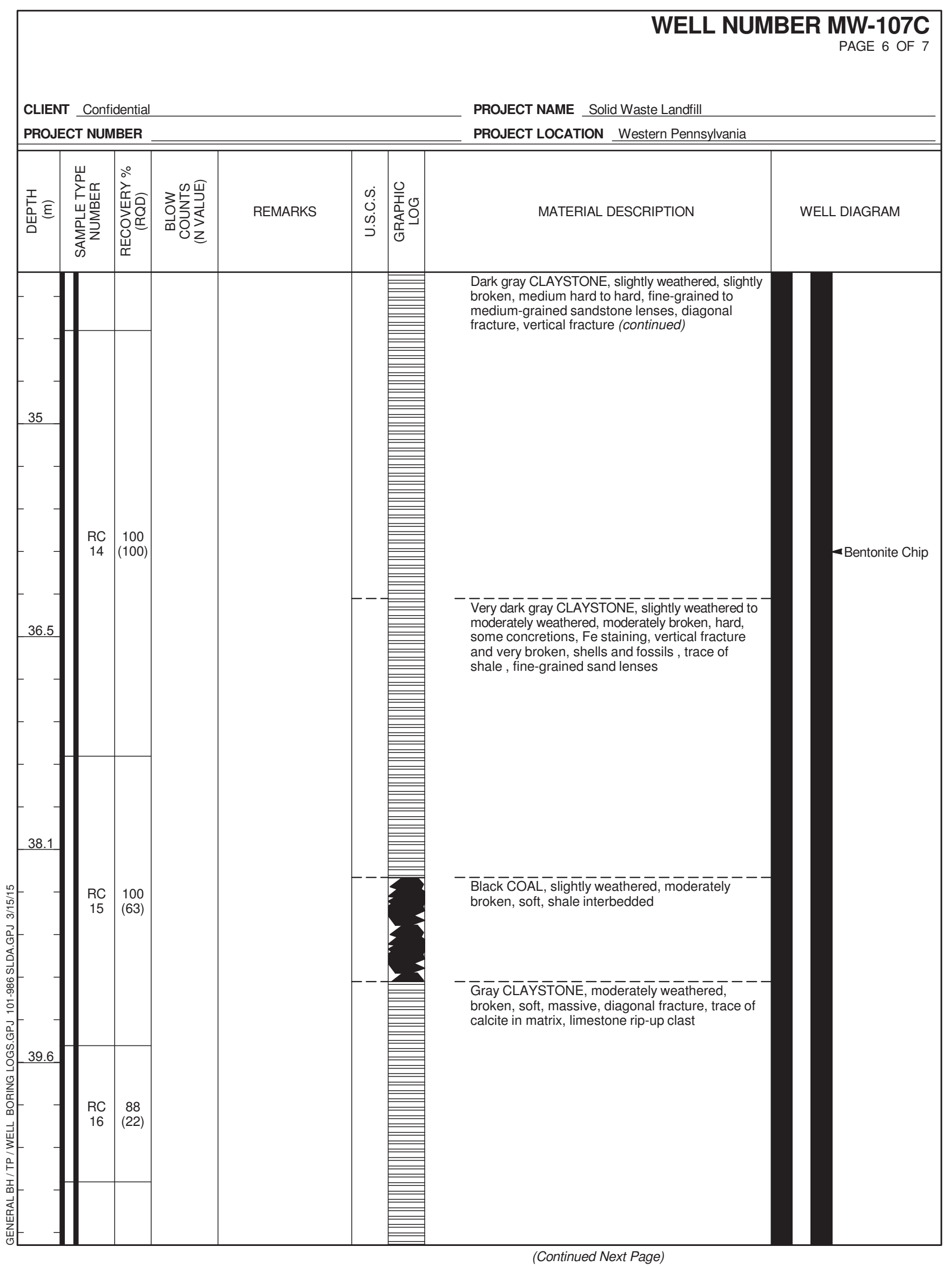




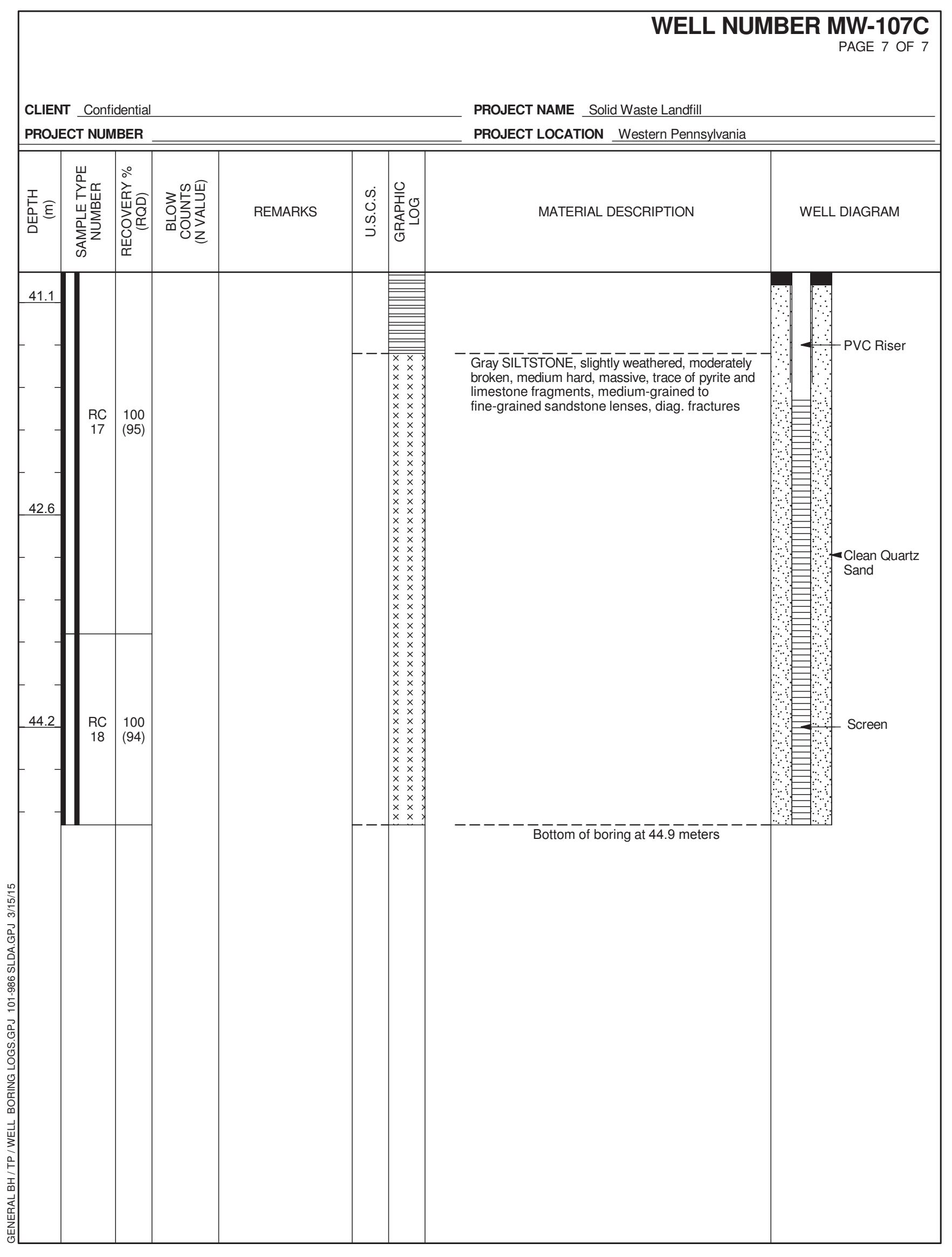


WELL NUMBER MW-113

PAGE 1 OF 2

CLIENT Confidential

PROJECT NUMBER

DATE STARTED $9 / 17 / 12$

DRILLING CONTRACTOR

DRILLING METHOD Hollow Stem Auger \& NQ Core

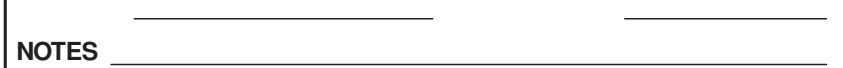

PROJECT NAME Solid Waste Landfill PROJECT LOCATION Western Pennsylvania GROUND ELEVATION BACKFILL 0.05 PVC Well WATER LEVELS:

BEFORE CORING

₹ AT END OF DRILLING $22.5 \mathrm{ft}$

AFTER DRILLING

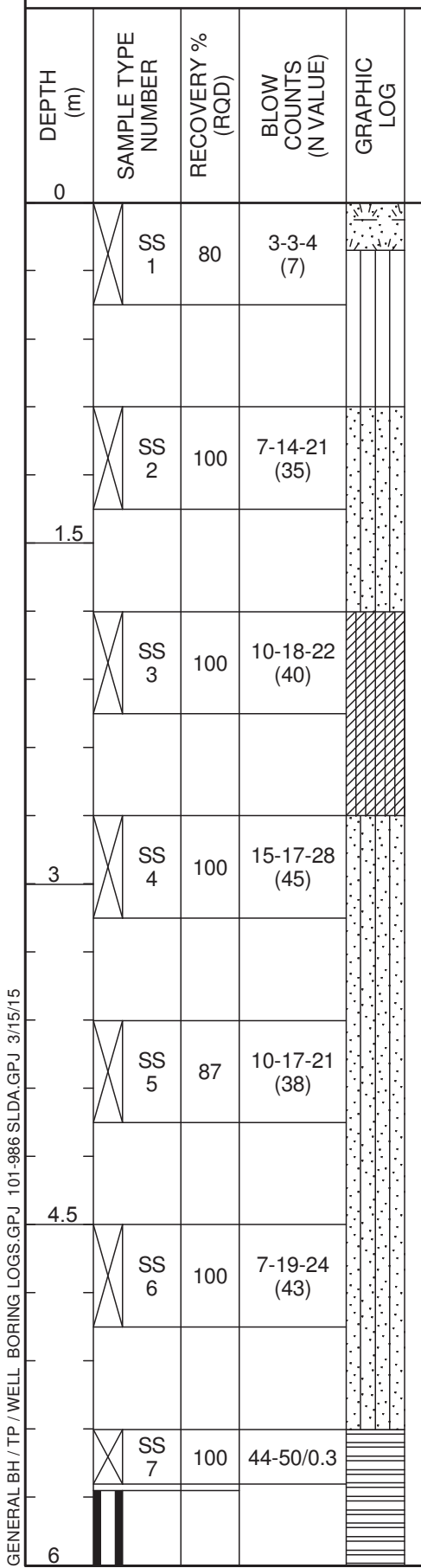

Tan sandy SILT, $\overline{\text { dry, }} \overline{\text { (RESIDUAL SOIL) }}$

$-\overline{B r o w n}$ and gray SIL $\bar{T}$, and clay, some shale fragments, moist $-\overline{-}, \overline{\text { REESIDUA }} \overline{\mathrm{S}}$ SOIL)

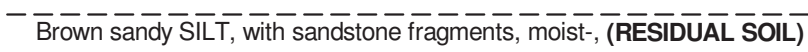

$-\bar{B} \bar{B} \overline{-} \bar{n} \overline{S A} \bar{N} \overline{D Y} \bar{S} \overline{H A} \overline{L E}, \overline{m o} \overline{d e r a t e l y}$ weathered, very broken, iron staining in fractures

(Continued Next Page)
WELL DIAGRAM

Bentonite Chip

- PVC Riser 


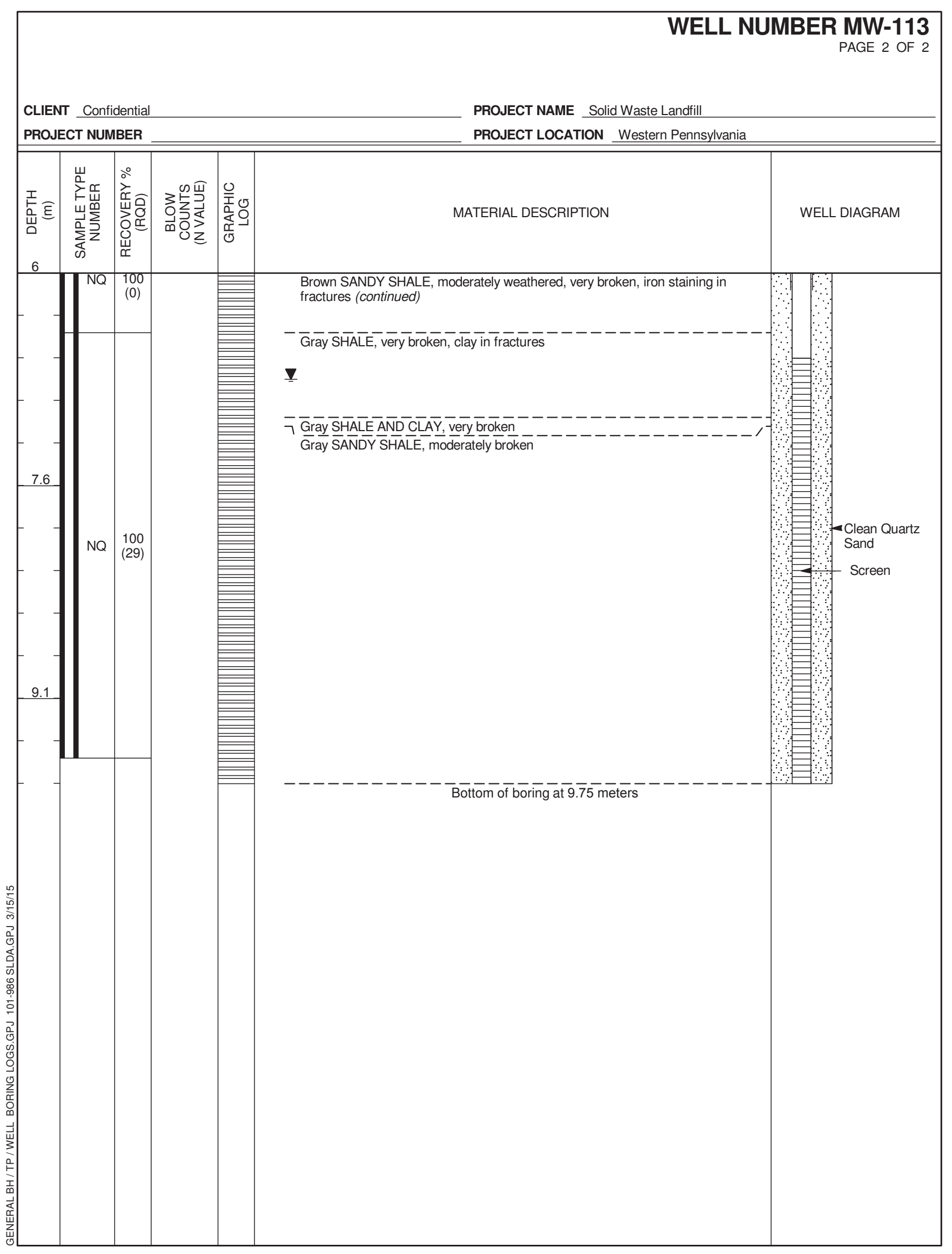




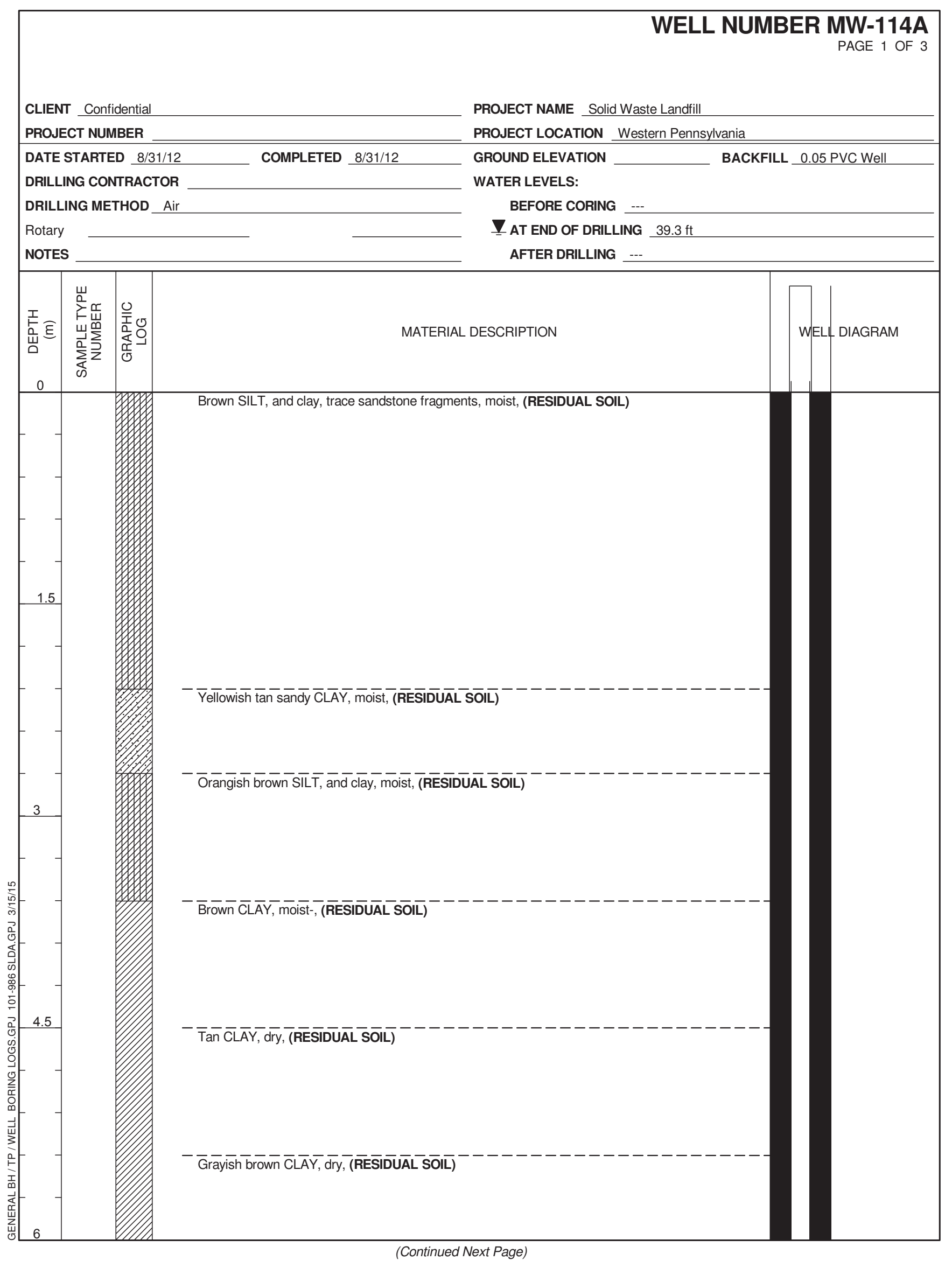

Figure B-15: MW-114A Boring Log 


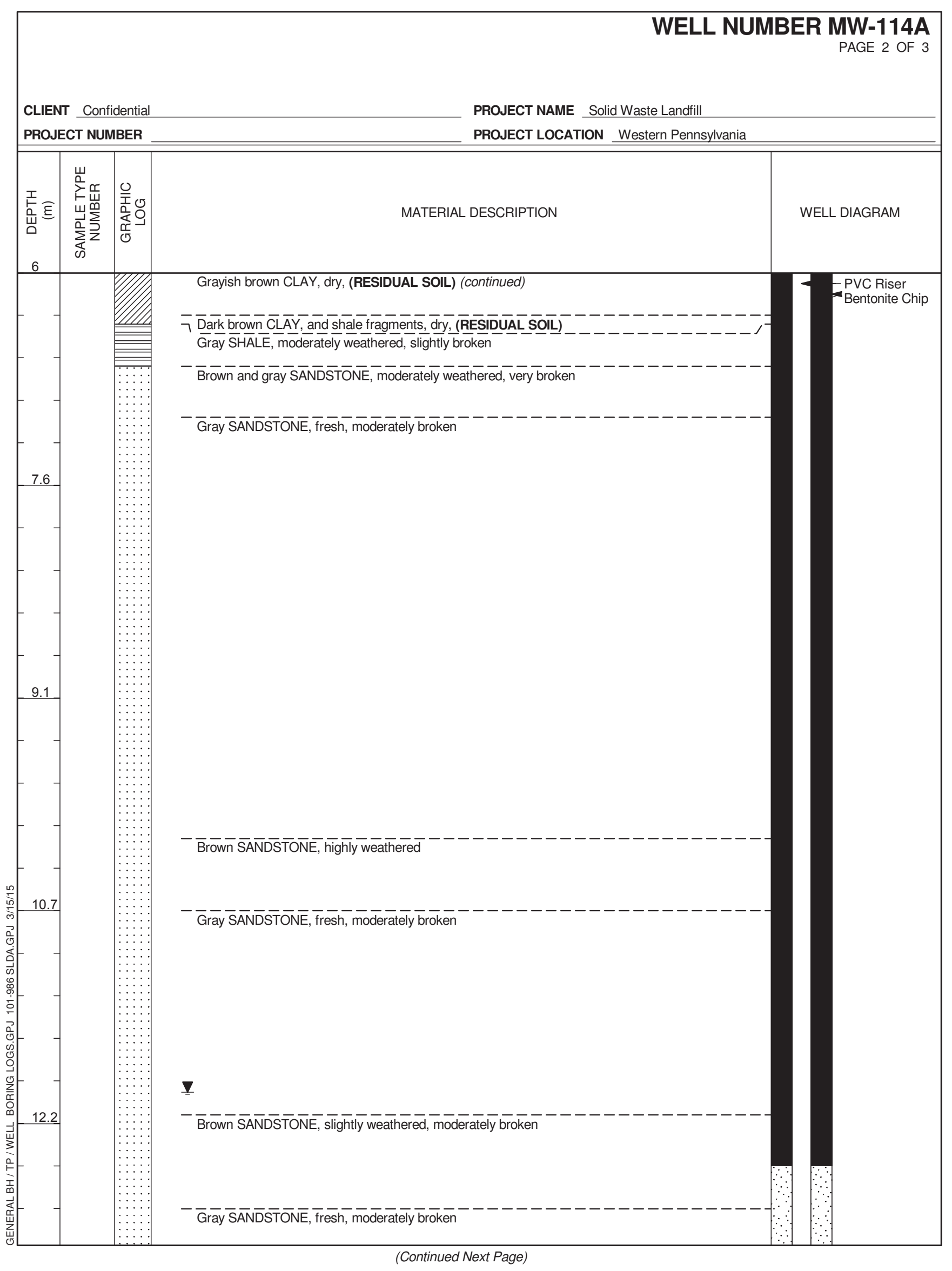




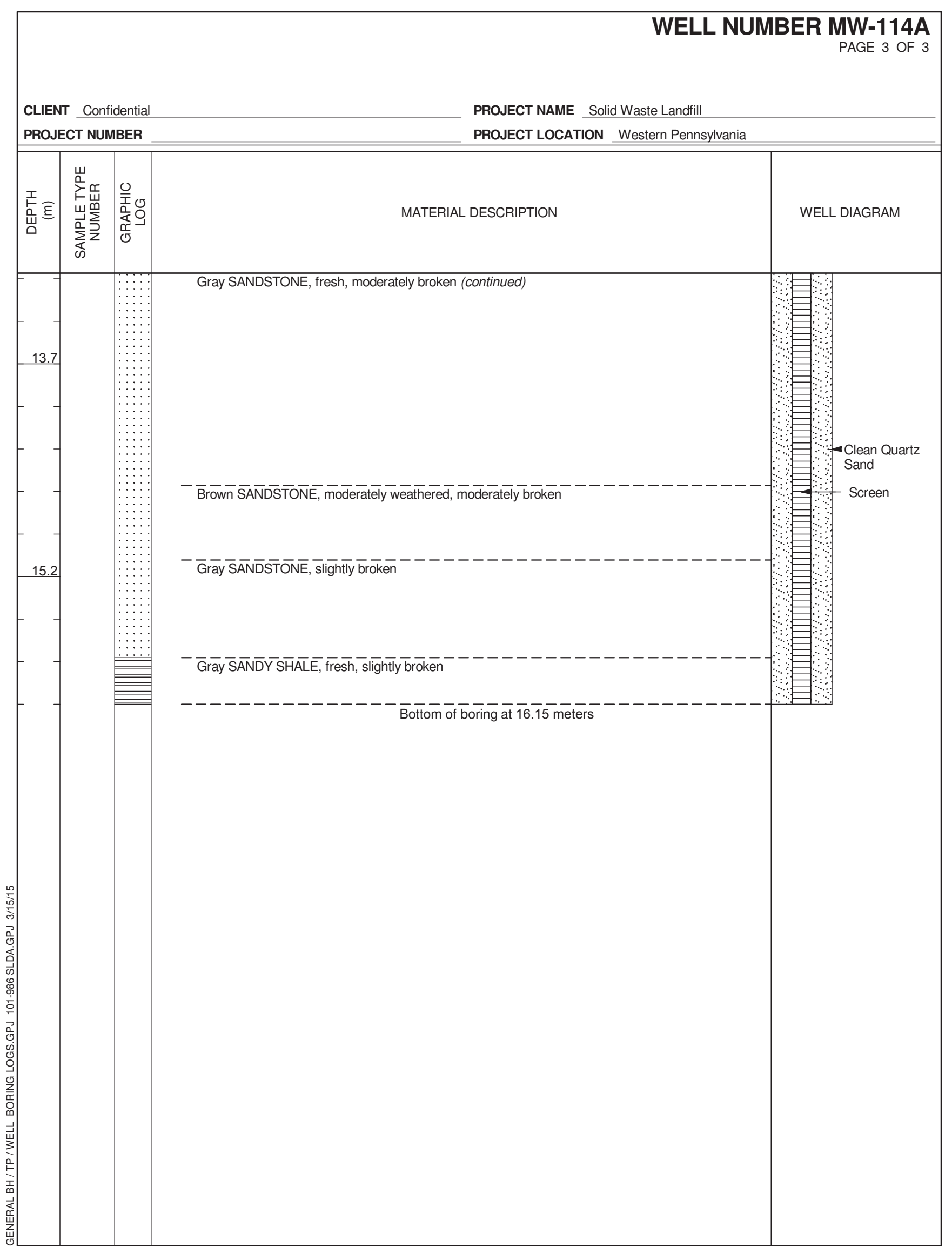




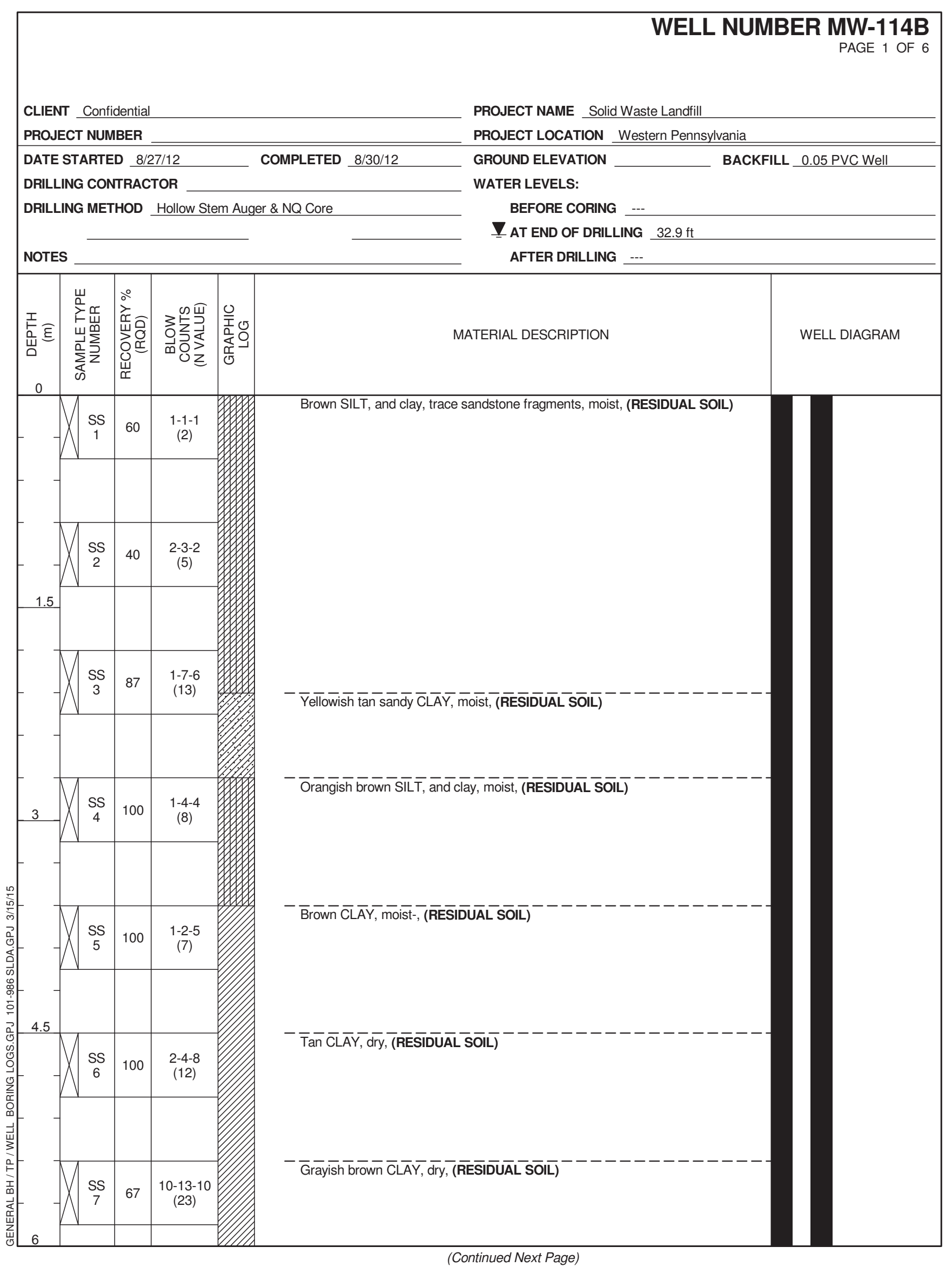

Figure B-16: MW-114B Boring Log 


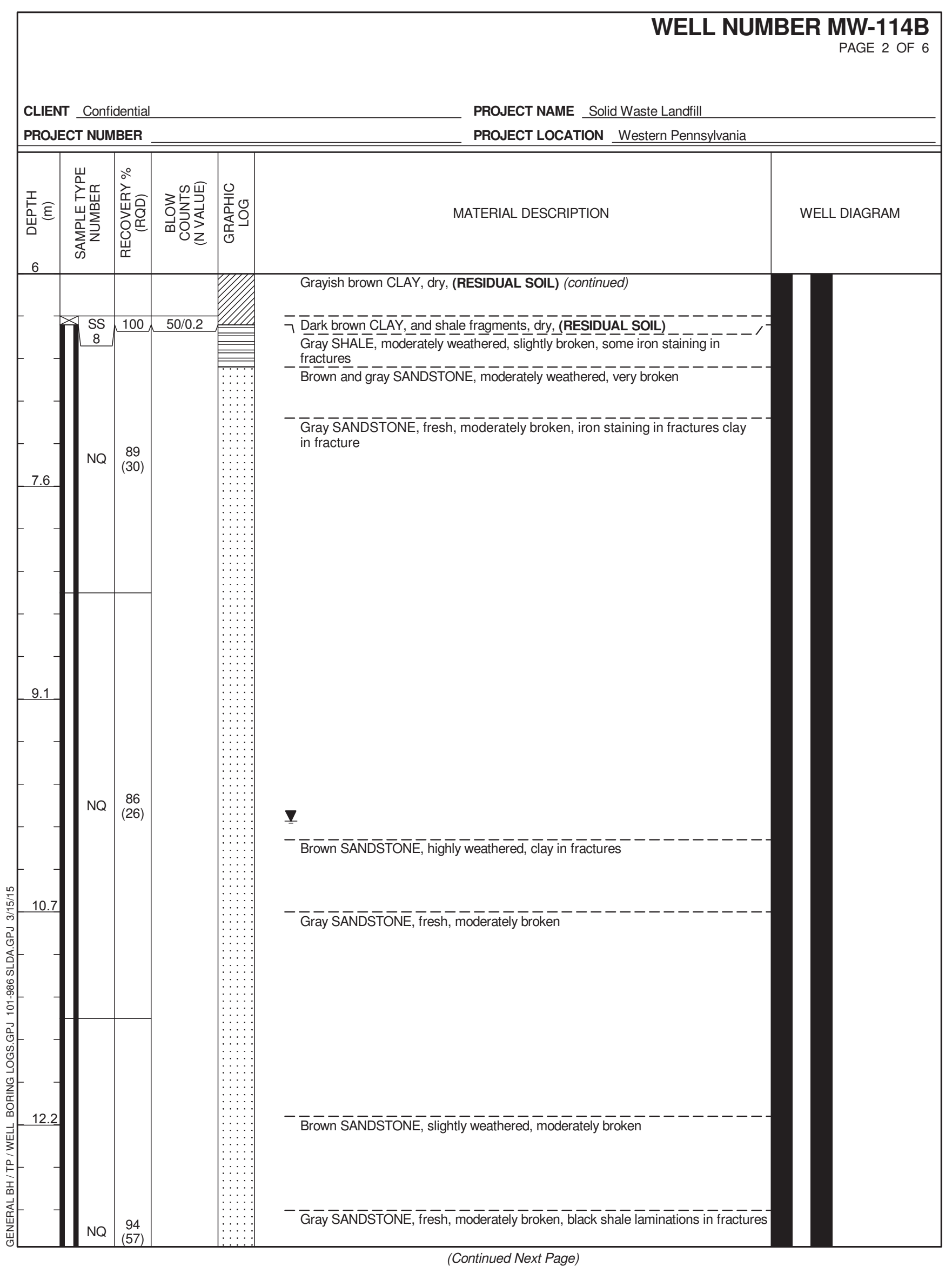




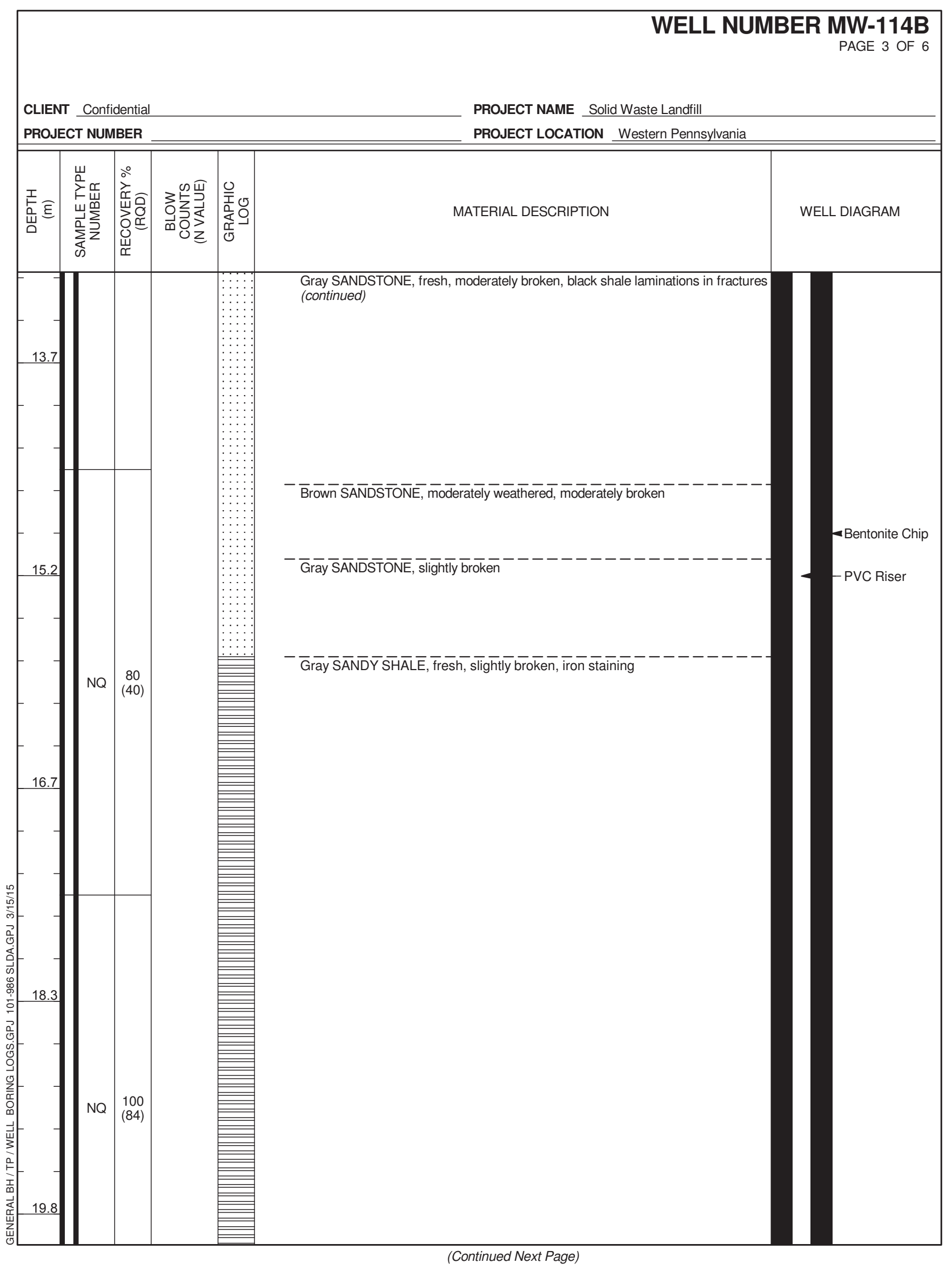




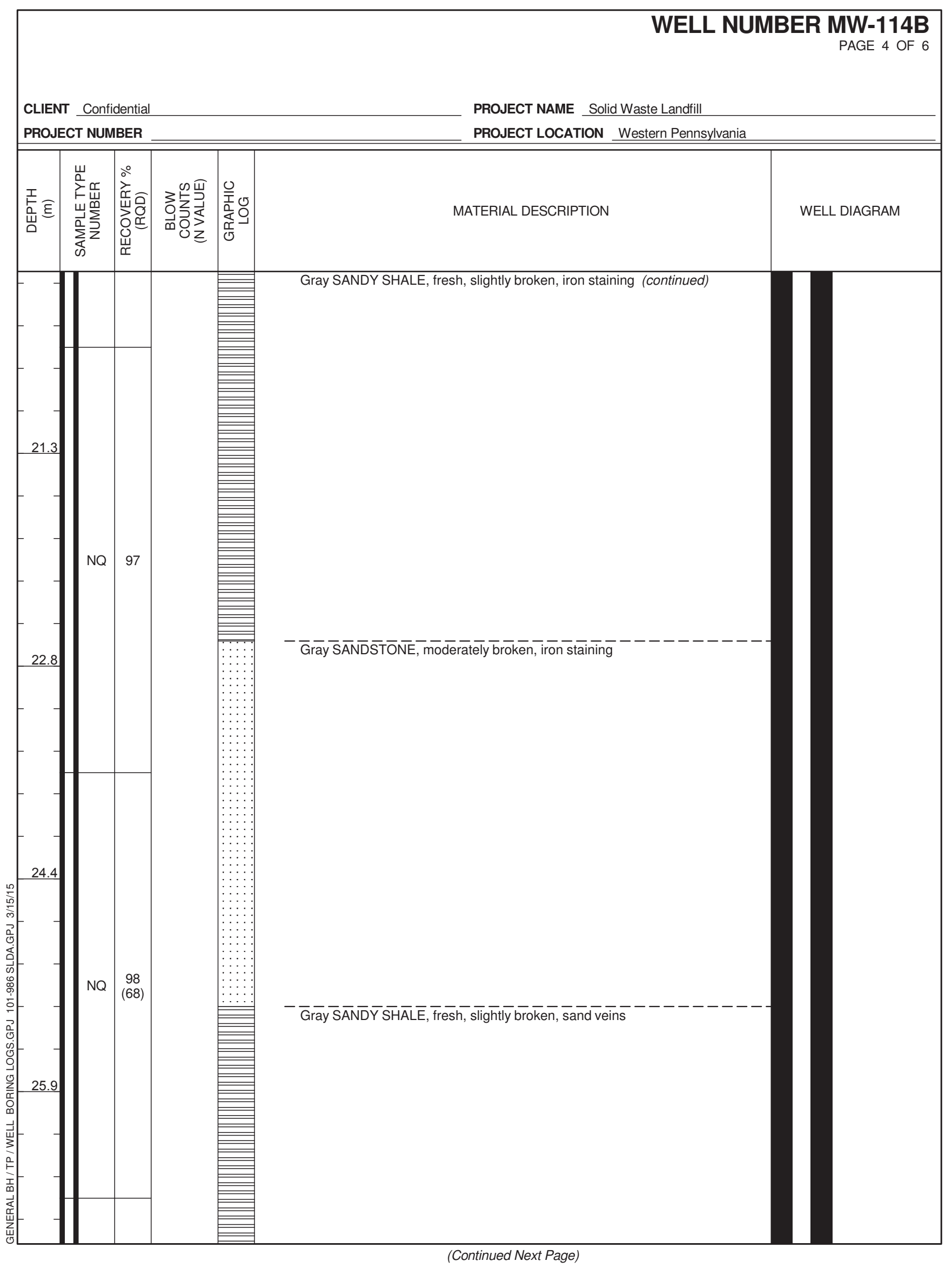




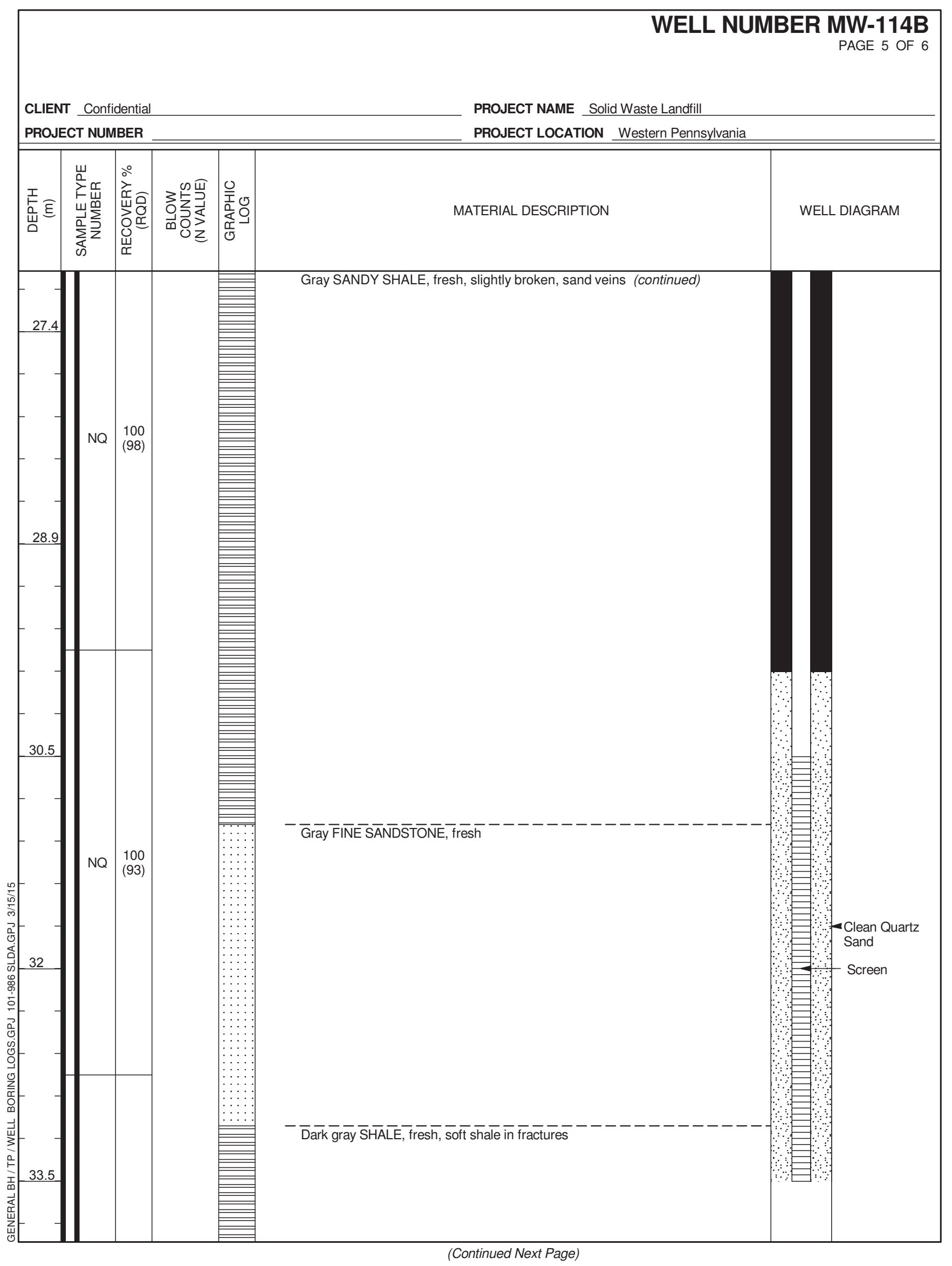




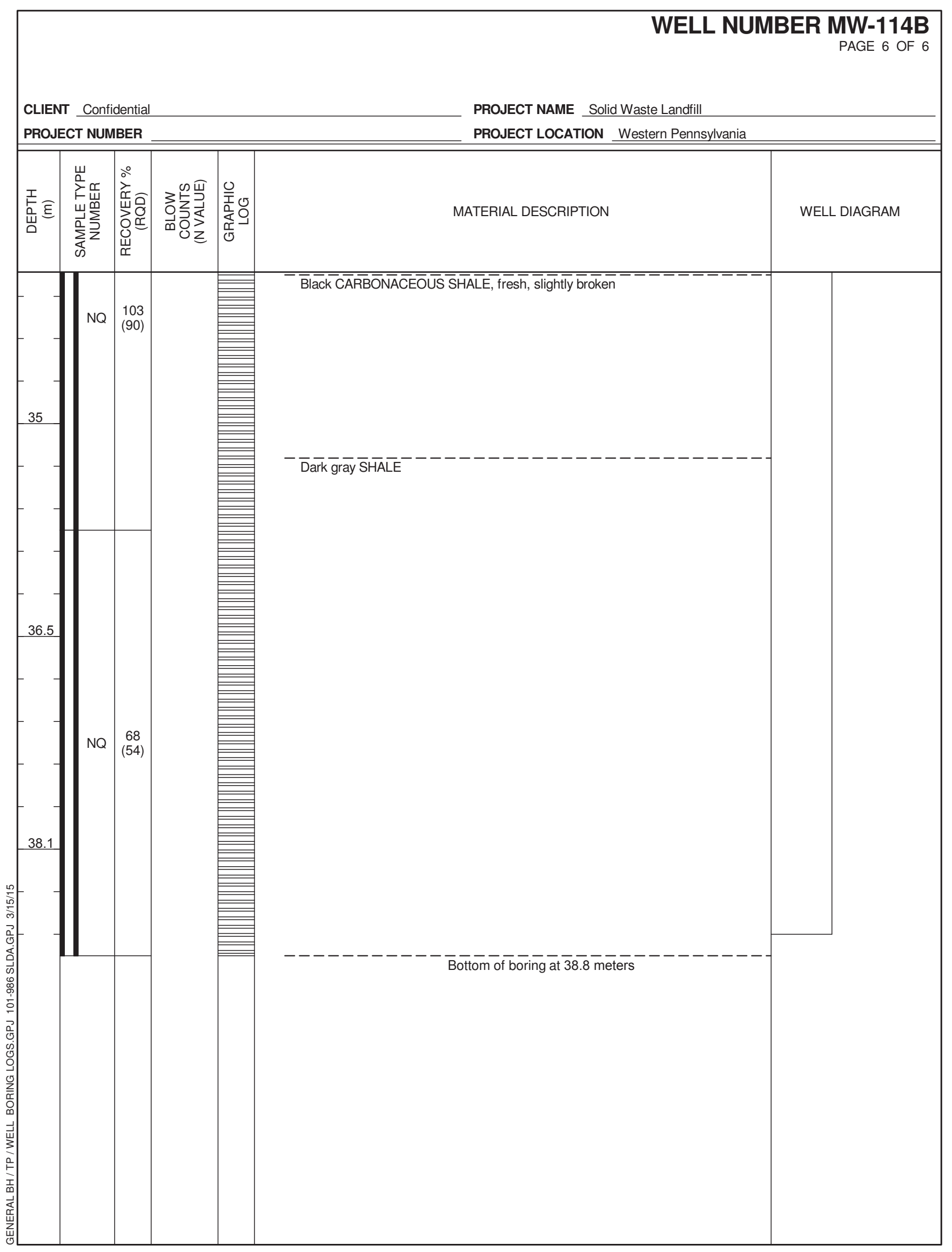




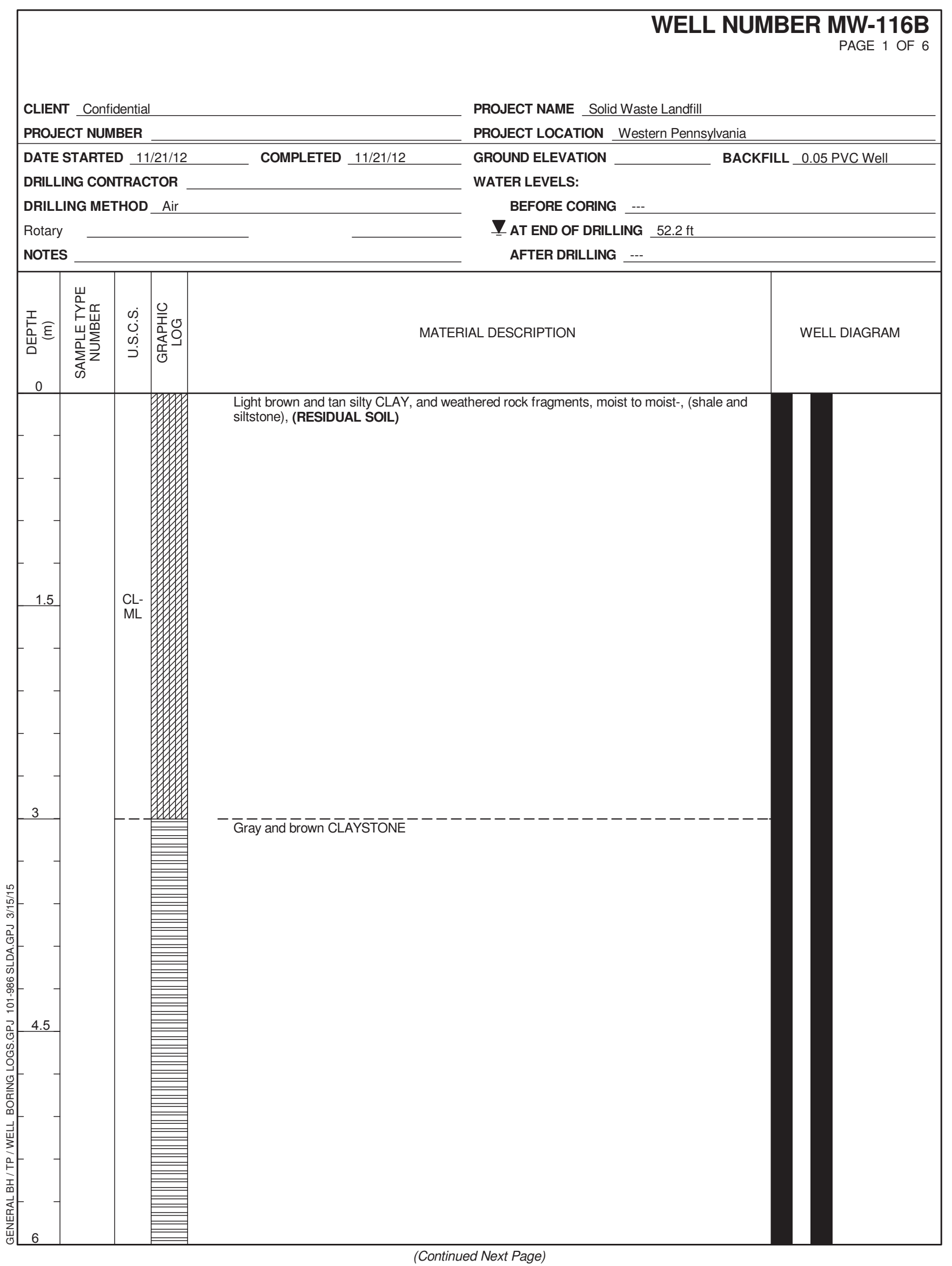

Figure B-17: MW-116B Boring Log 


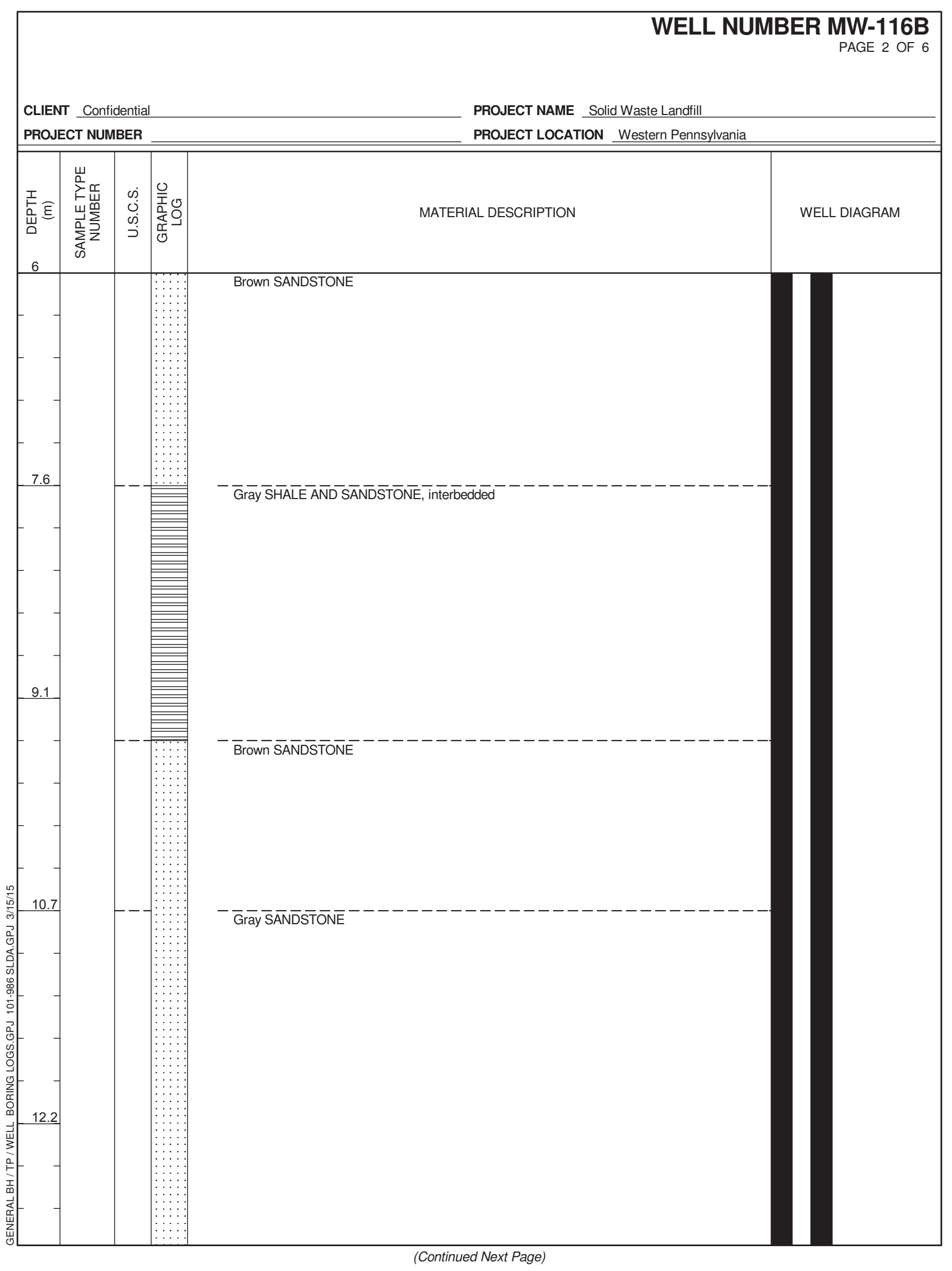




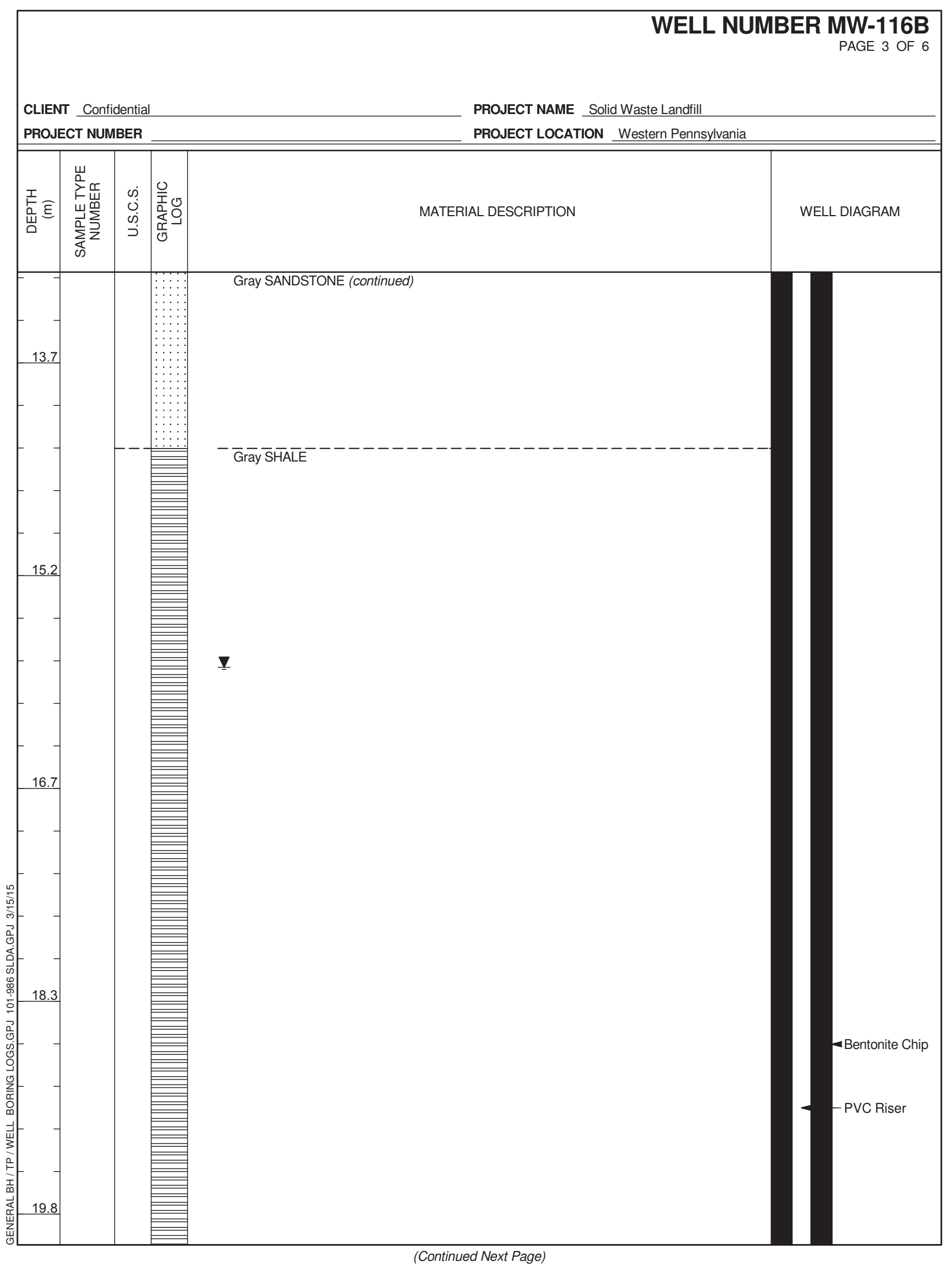




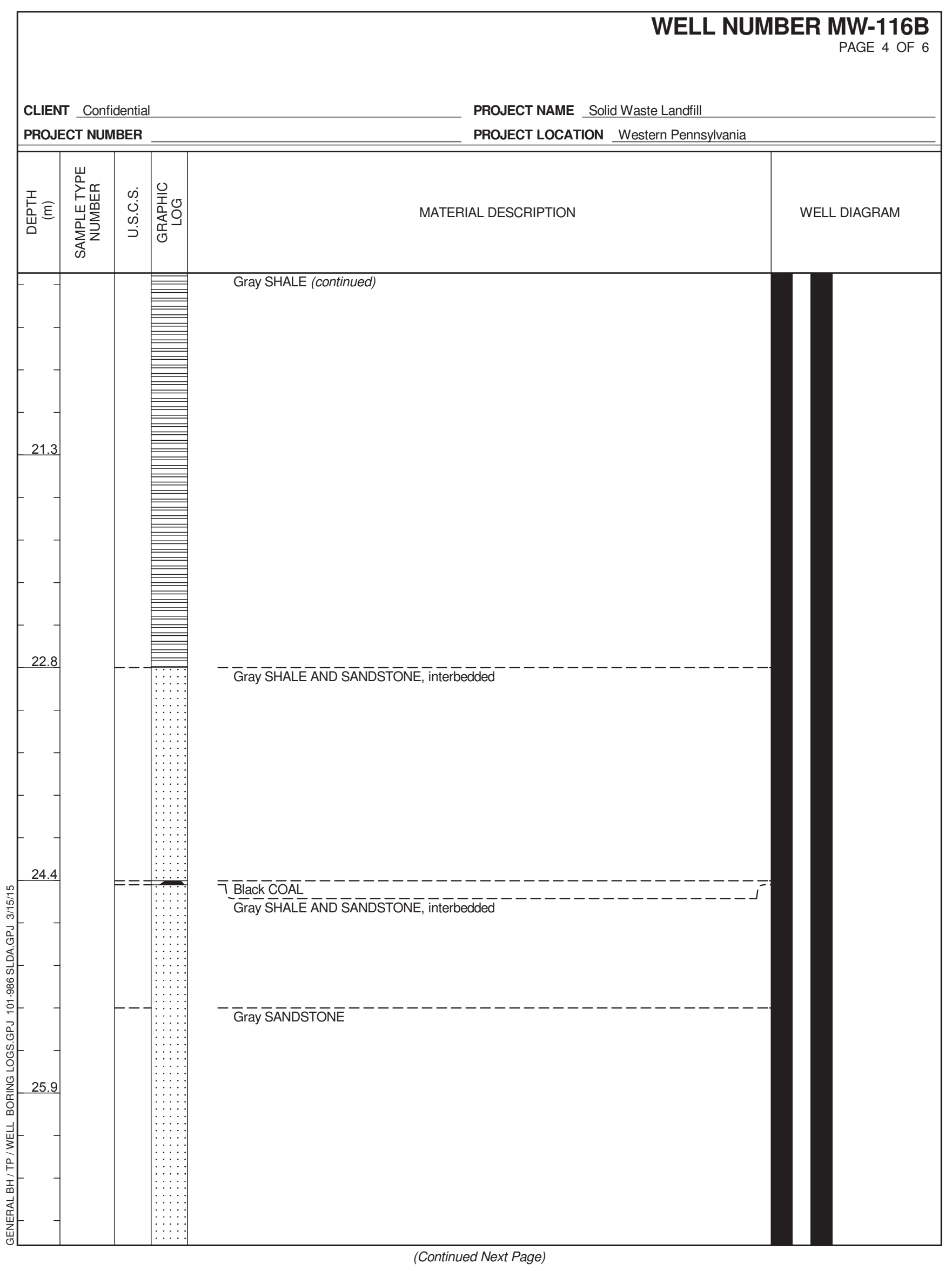




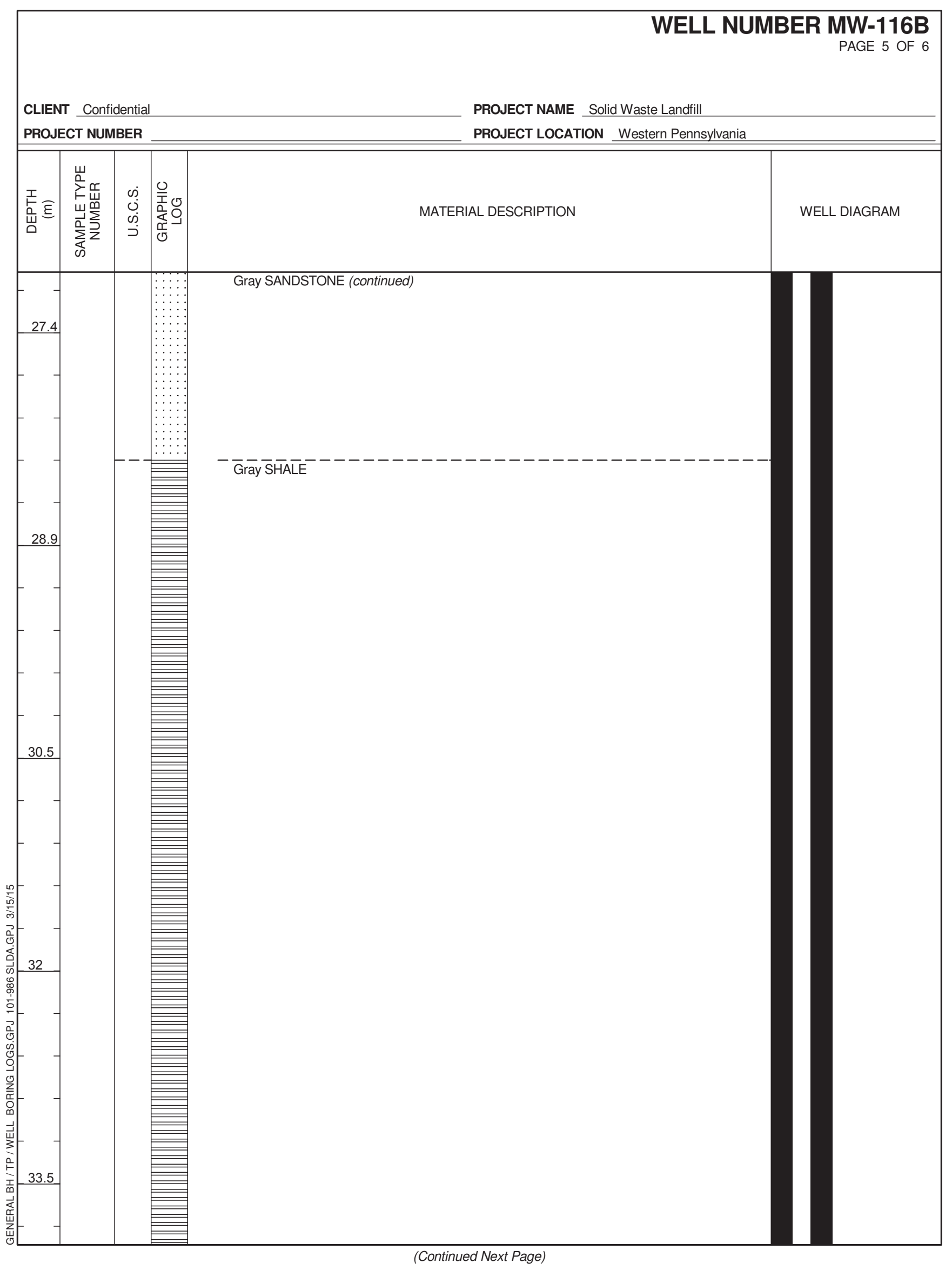




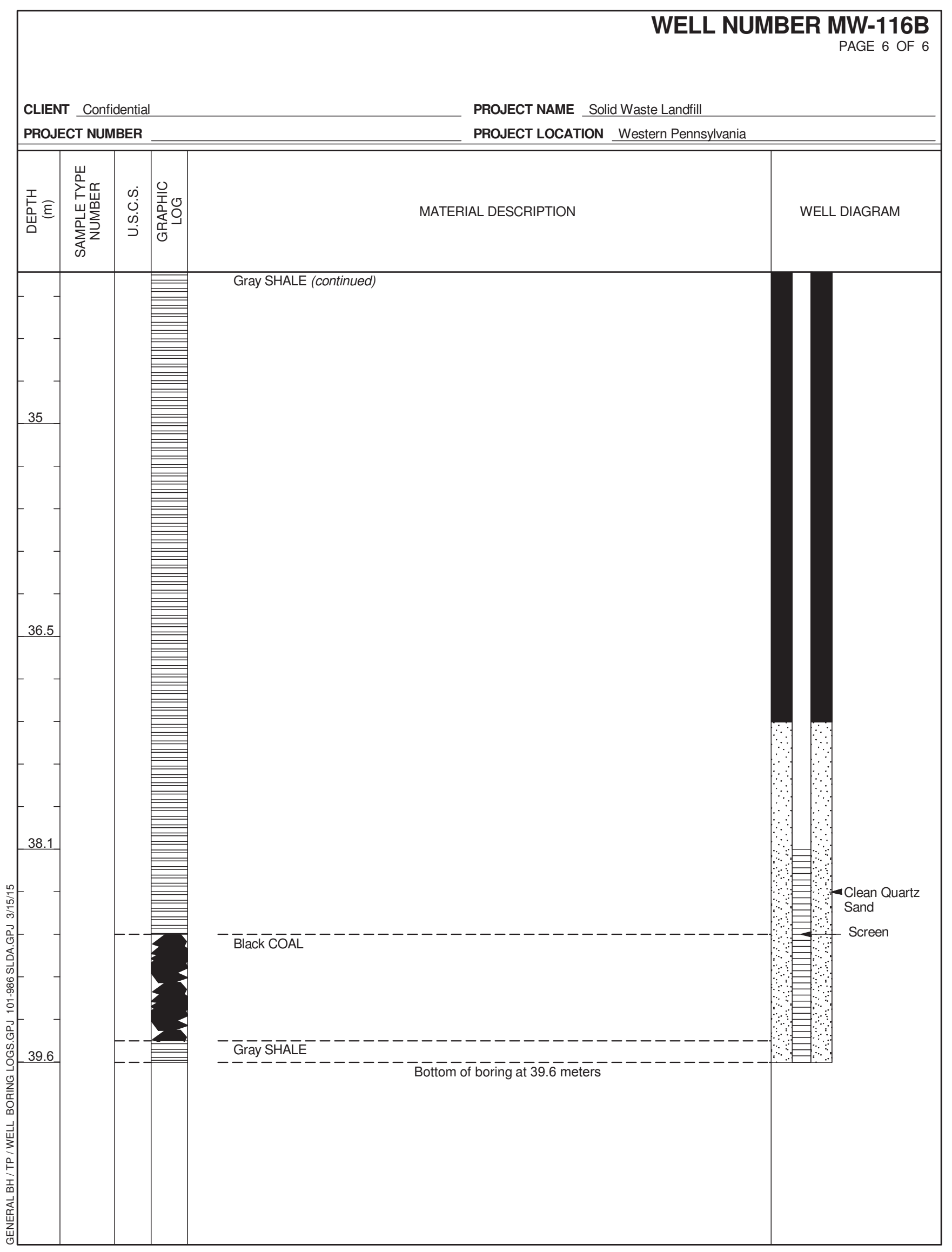




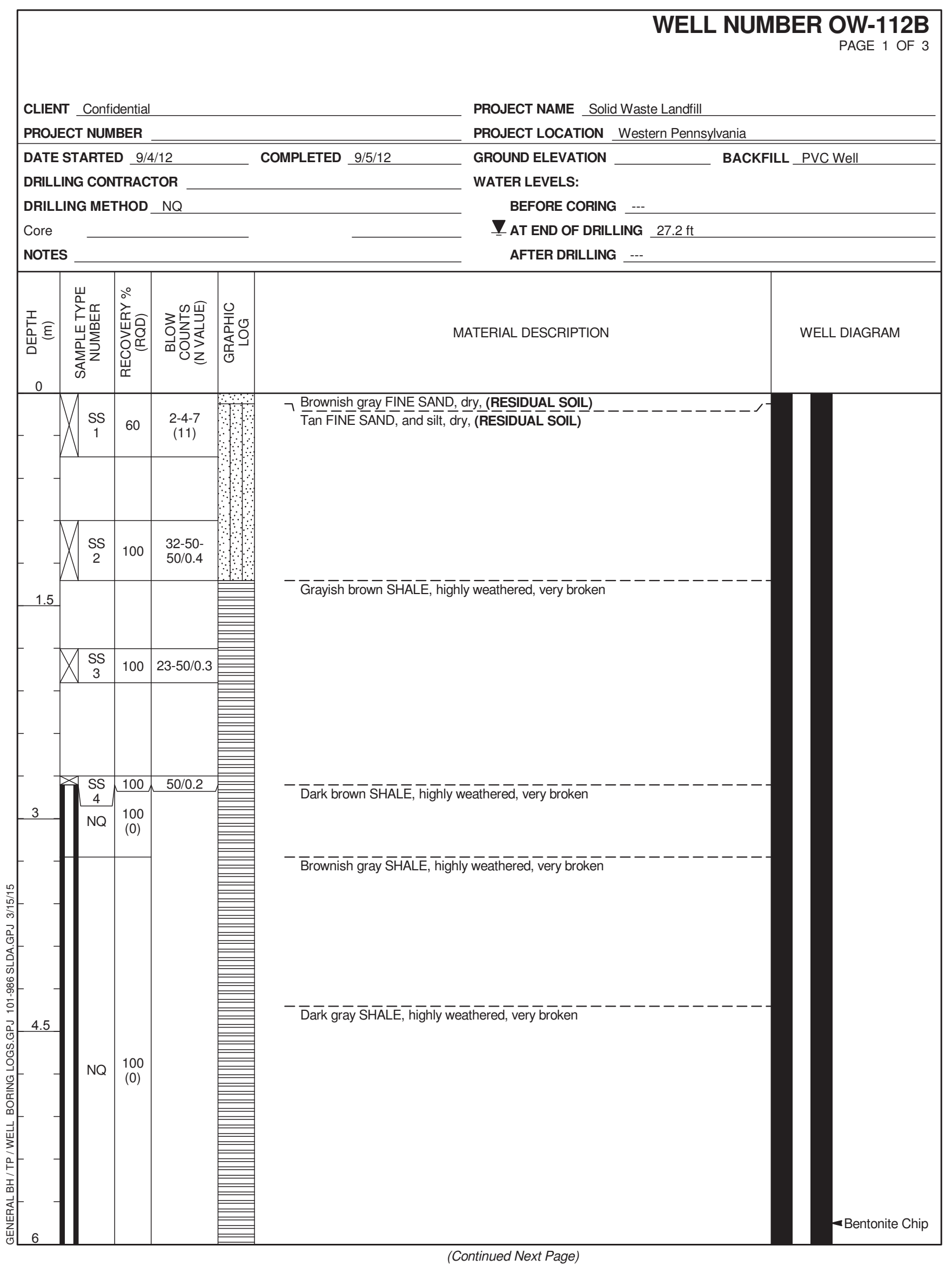

Figure B-18: OW-112B Boring Log 


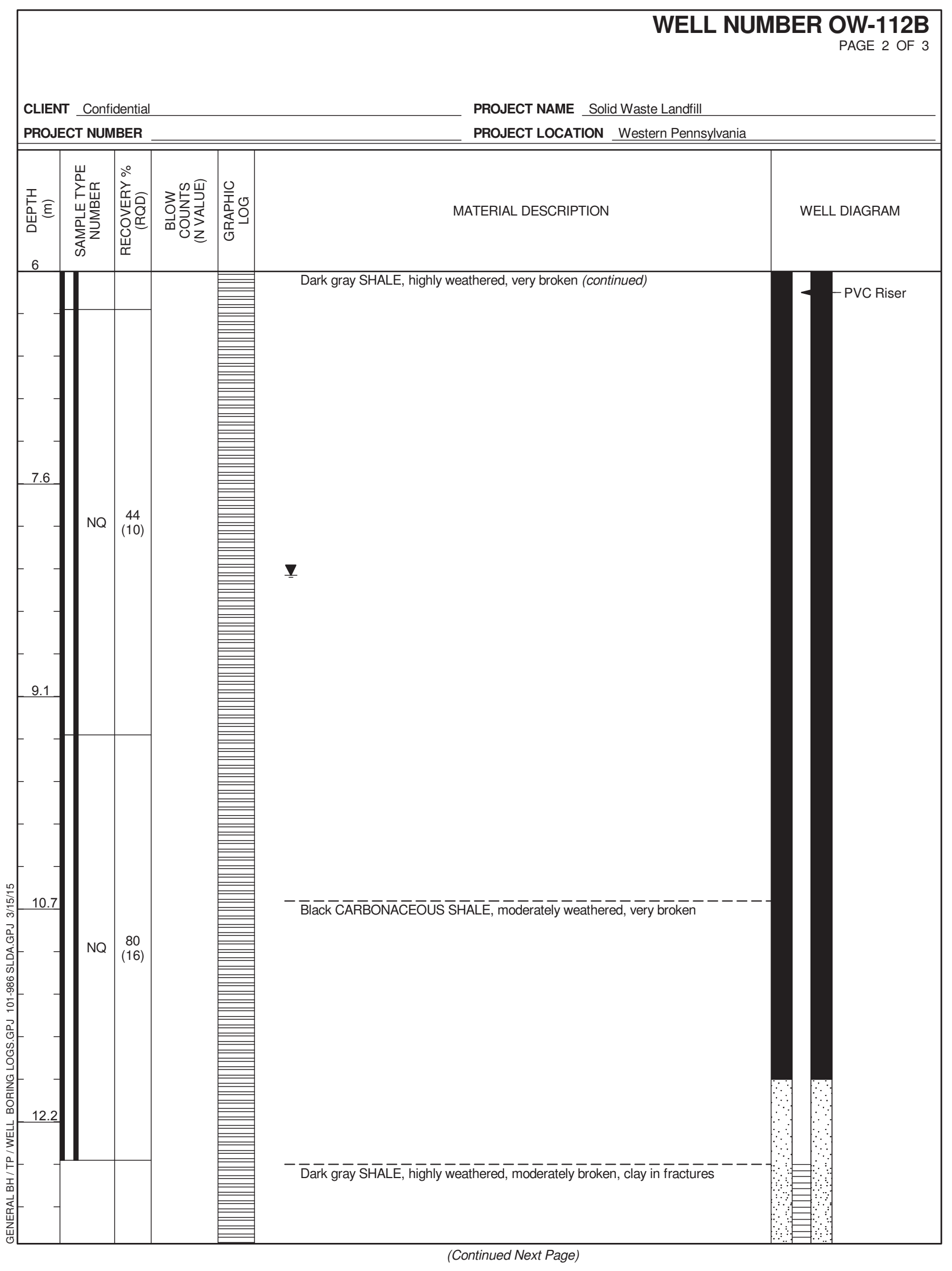




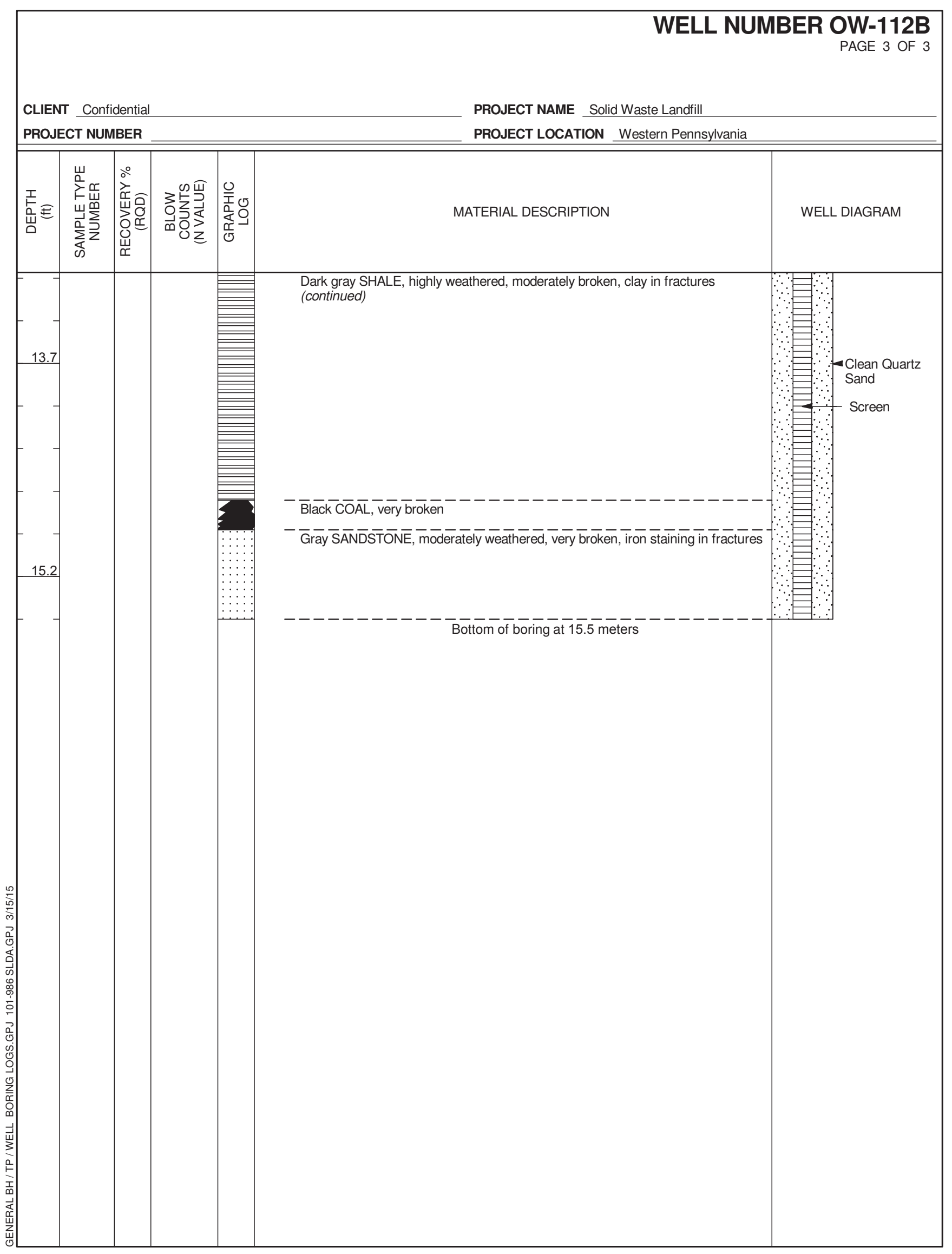


APPENDIX C

SLUG TEST AND PUMPING TEST RESULTS 


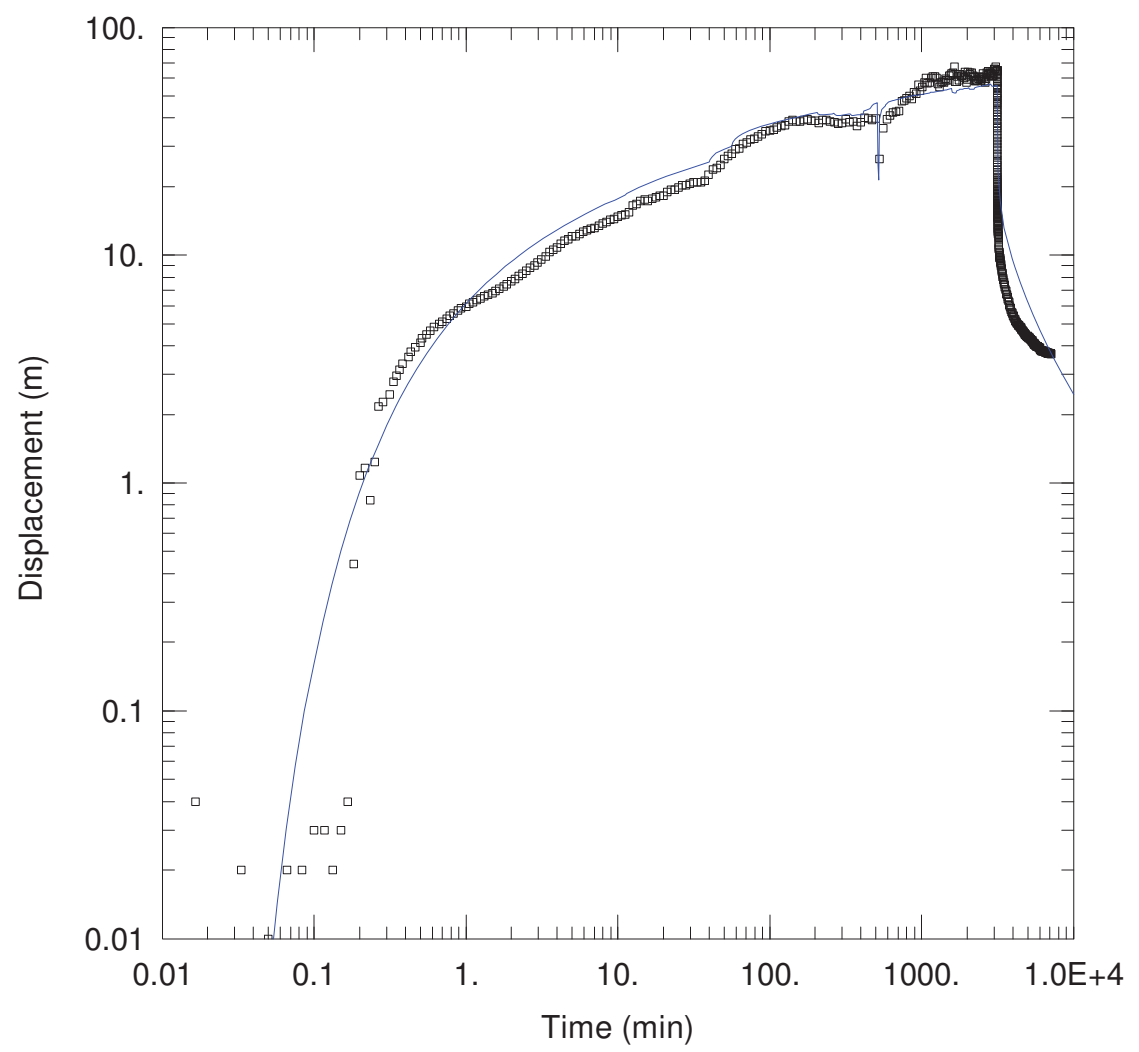

\section{WELL TEST ANALYSIS}

Data Set: $P:|\ldots| 1$ 12-10_allData.aqt Date: $03 / 07 / 15$

Time: 09:38:21

PROJECT INFORMATION

Test Well: $12-10$ Test

Date: $10 / 3 / 12$

\section{AQUIFER DATA}

Saturated Thickness: $34.6 \mathrm{~m}$

WELL DATA

Pumping Wells

\begin{tabular}{|l|c|c|}
\hline Well Name & $\mathrm{X}(\mathrm{m})$ & $\mathrm{Y}(\mathrm{m})$ \\
\hline $12-10$ & 0 & 0 \\
\hline
\end{tabular}

Observation Wells

\begin{tabular}{|l|c|c|}
\hline Well Name & $\mathrm{X}(\mathrm{m})$ & $\mathrm{Y}(\mathrm{m})$ \\
\hline $\mathrm{0} 12-10$ & 0 & 0 \\
\hline
\end{tabular}

\section{SOLUTION}

Aquifer Model: Unconfined

Solution Method: Neuman

$\mathrm{T}=0.1884 \mathrm{~cm}^{2} / \mathrm{sec}$

Sy $=0.1$

$S=0.1052$

$B=0.001$

Figure C-1: 12-10 Pumping Test 


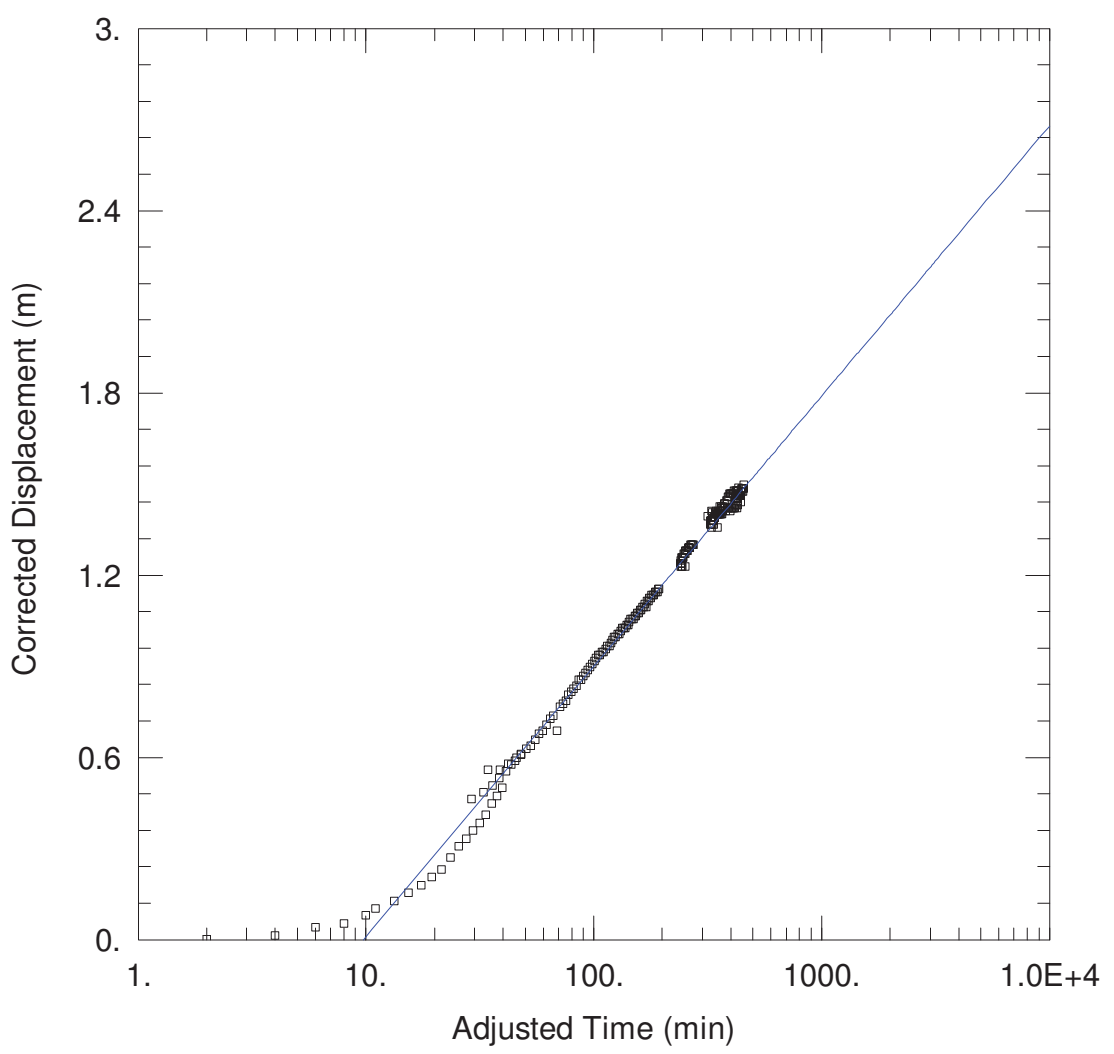

WELL TEST ANALYSIS

Data Set: P:I...12-10A_single_noRec_FINAL_111212.aqt

Date: $03 / 07 / 15 \quad$ Time: 09:37:27

PROJECT INFORMATION

Test Well: $12-10 \mathrm{~A}$

Test Date: $10 / 3 / 12$

\section{AQUIFER DATA}

Saturated Thickness: $\underline{34.6 \mathrm{~m}} \quad$ Anisotropy Ratio $(\mathrm{Kz} / \mathrm{Kr}): \underline{1.166 \mathrm{E}+4}$

WELL DATA

\section{Pumping Wells}

\begin{tabular}{|l|c|c|}
\hline Well Name & $\mathrm{X}(\mathrm{m})$ & $\mathrm{Y}(\mathrm{m})$ \\
\hline $12-10$ & 0 & 0 \\
\hline
\end{tabular}

Observation Wells

\begin{tabular}{|l|c|c|}
\hline Well Name & $X(\mathrm{~m})$ & $\mathrm{Y}(\mathrm{m})$ \\
\hline $\mathrm{a} 12-10 \mathrm{~A}$ & 0 & 3.9 \\
\hline
\end{tabular}

\section{SOLUTION}

Aquifer Model: Unconfined

Solution Method: $\underline{\text { Cooper-Jacob }}$

$\mathrm{T}=3.284 \mathrm{~cm}^{2} / \mathrm{sec}$

$S=0.02827$

Figure C-2: 12-10A Pumping Test 


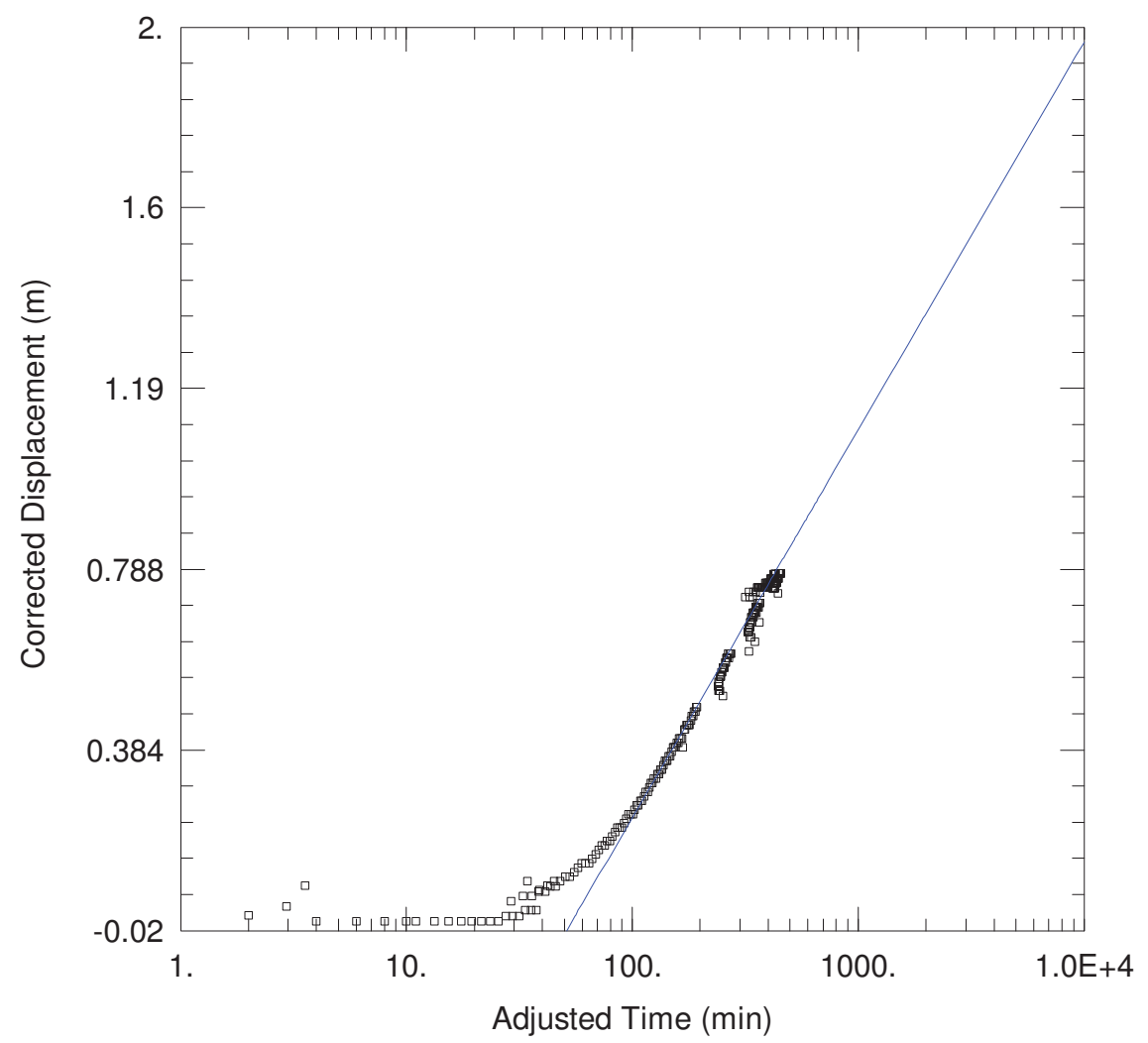

WELL TEST ANALYSIS

Data Set: P:I...12-10B_single_noRec_FINAL_111212.aqt

Date: $03 / 07 / 15 \quad$ Time: 09:37:09

PROJECT INFORMATION

Test Well: $12-10 \mathrm{~B}$

Test Date: $10 / 3 / 12$

\section{AQUIFER DATA}

Saturated Thickness: $\underline{34.6 \mathrm{~m}} \quad$ Anisotropy Ratio $(\mathrm{Kz} / \mathrm{Kr}): \underline{1.87}$

WELL DATA

\section{Pumping Wells}

\begin{tabular}{|l|c|c|}
\hline Well Name & $\mathrm{X}(\mathrm{m})$ & $\mathrm{Y}(\mathrm{m})$ \\
\hline $12-10$ & 0 & 0 \\
\hline
\end{tabular}

\begin{tabular}{|l|c|c|}
\hline Well Name & Observation Wells \\
\hline $012-10 \mathrm{~B}$ & $\mathrm{X}(\mathrm{m})$ & $\mathrm{Y}(\mathrm{m})$ \\
\hline
\end{tabular}

\section{SOLUTION}

Aquifer Model: Unconfined

Solution Method: Cooper-Jacob

$\mathrm{T}=3.368 \mathrm{~cm}^{2} / \mathrm{sec}$

$S=0.03814$

Figure C-3: 12-10B Pumping Test 


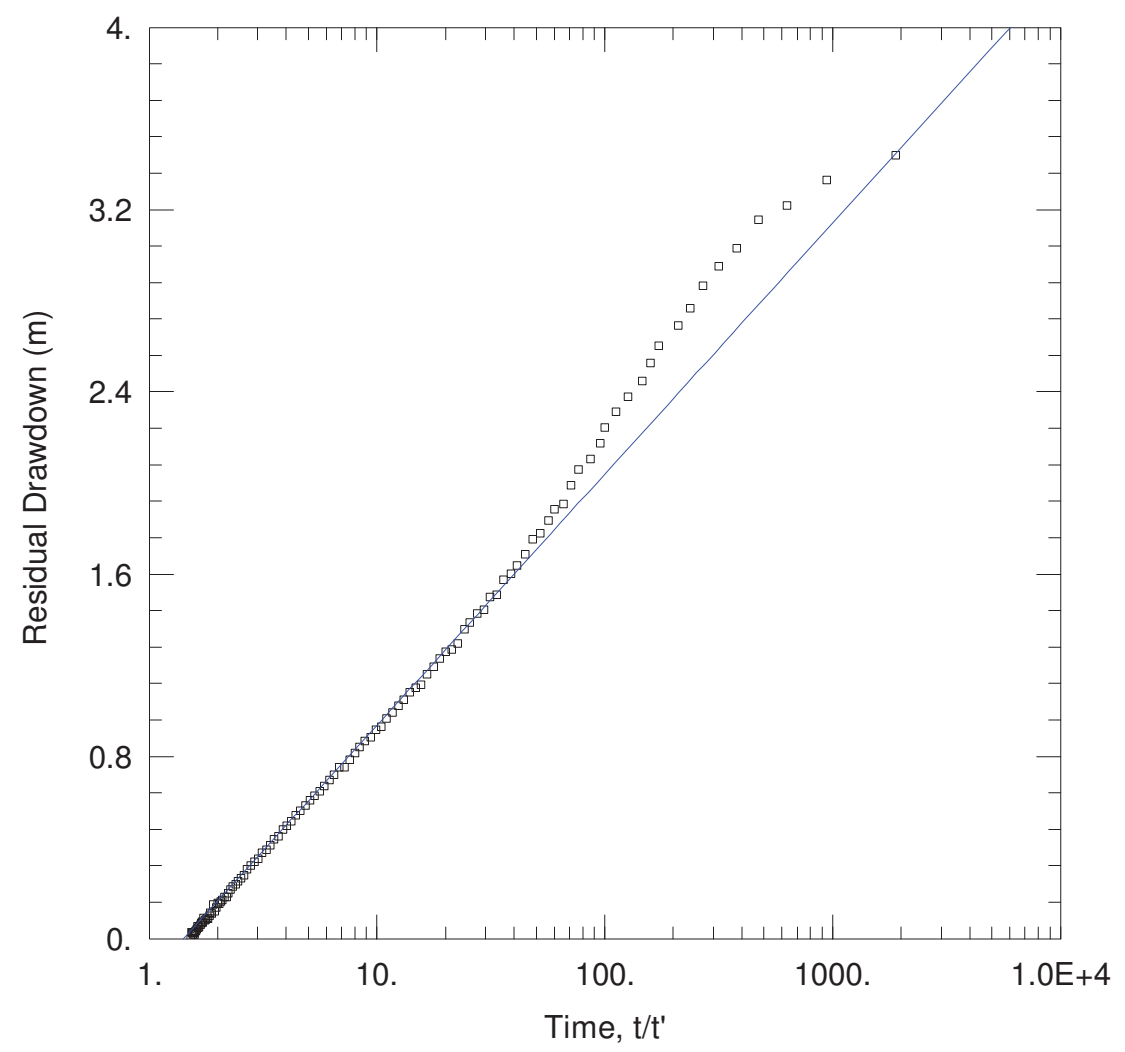

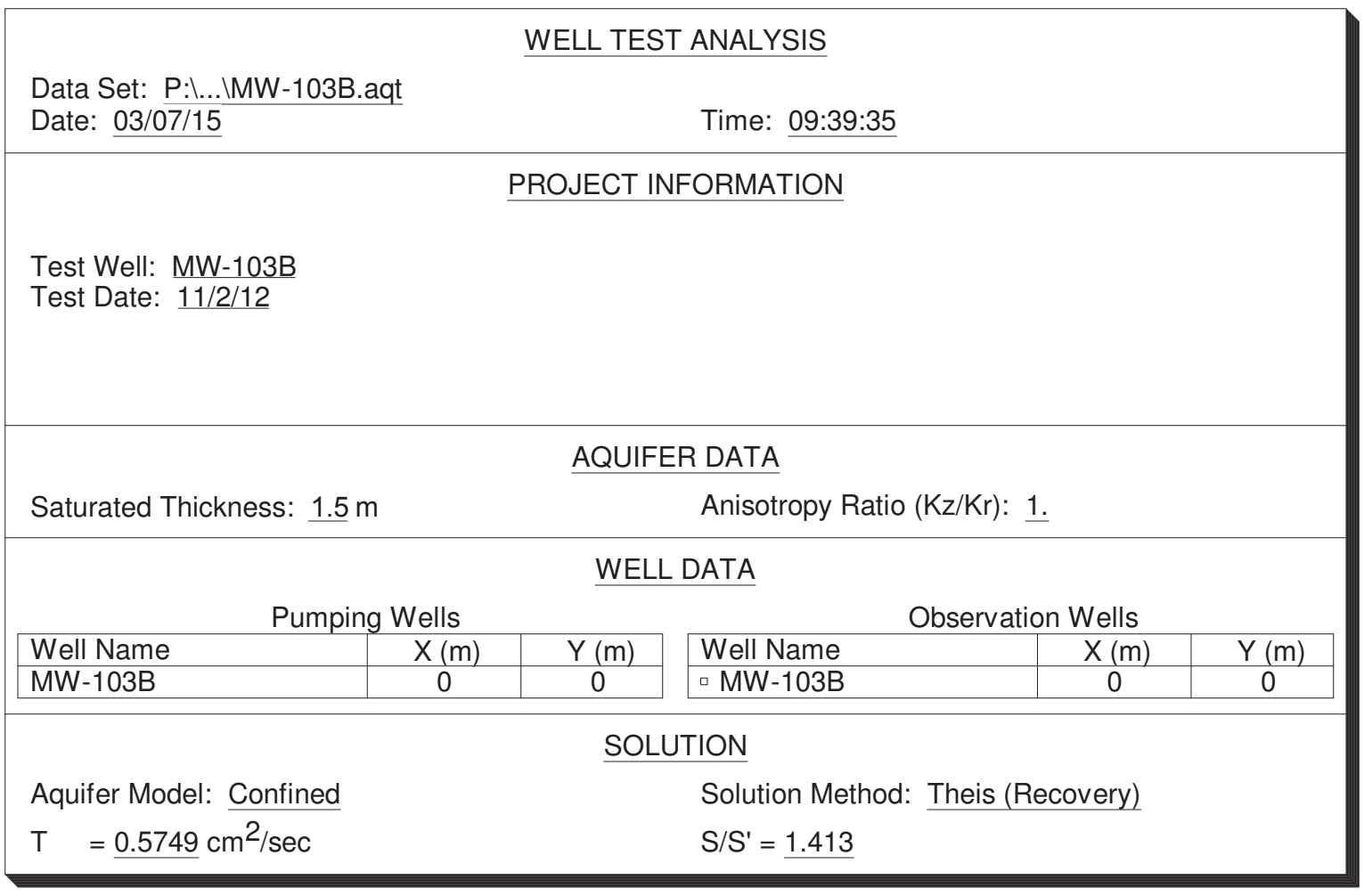

Figure C-4: MW-103B Pumping Test 


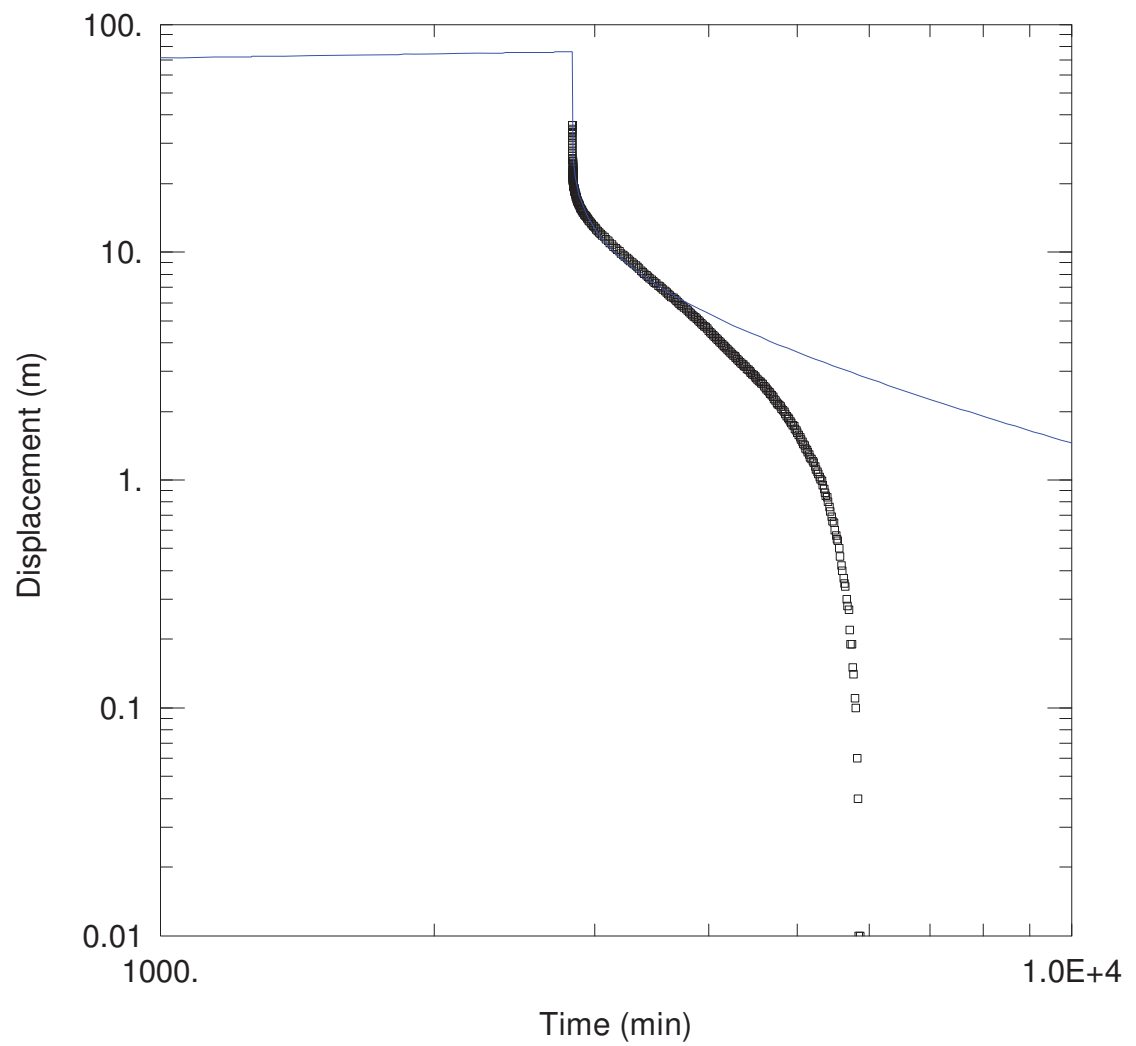

WELL TEST ANALYSIS

Data Set: $P: \backslash \ldots \mid M W-103 B . a q t$

Date: $\underline{03 / 07 / 15}$

Time: 09:44:54

PROJECT INFORMATION

Test Well: MW-103B

Test Date: 12/5/12

WELL DATA

Pumping Wells

Well Name

\begin{tabular}{c|c}
$\mathrm{X}(\mathrm{m})$ & $\mathrm{Y}(\mathrm{m})$ \\
0 & 0
\end{tabular}

Observation Wells

MW-103B

\section{SOLUTION}

Aquifer Model: Confined

Solution Method: Theis

$\mathrm{T}=0.2829 \mathrm{~cm}^{2} / \mathrm{sec}$

$\mathrm{S}=3.06 \mathrm{E}-5$

$\mathrm{Kz} / \mathrm{Kr}=1$.

b $=1.5 \mathrm{~m}$

Figure C-5: MW-103B Slug Test 


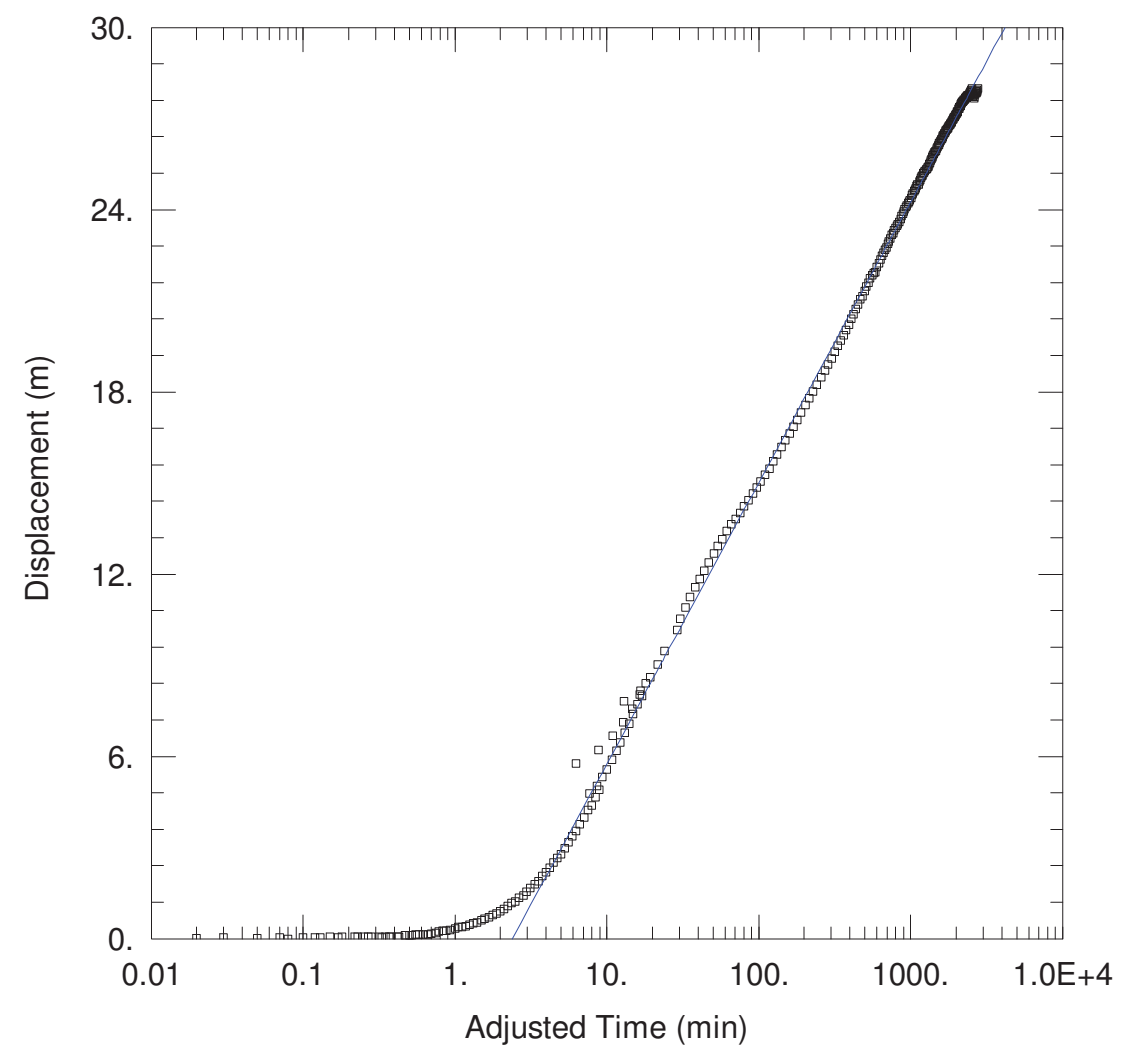

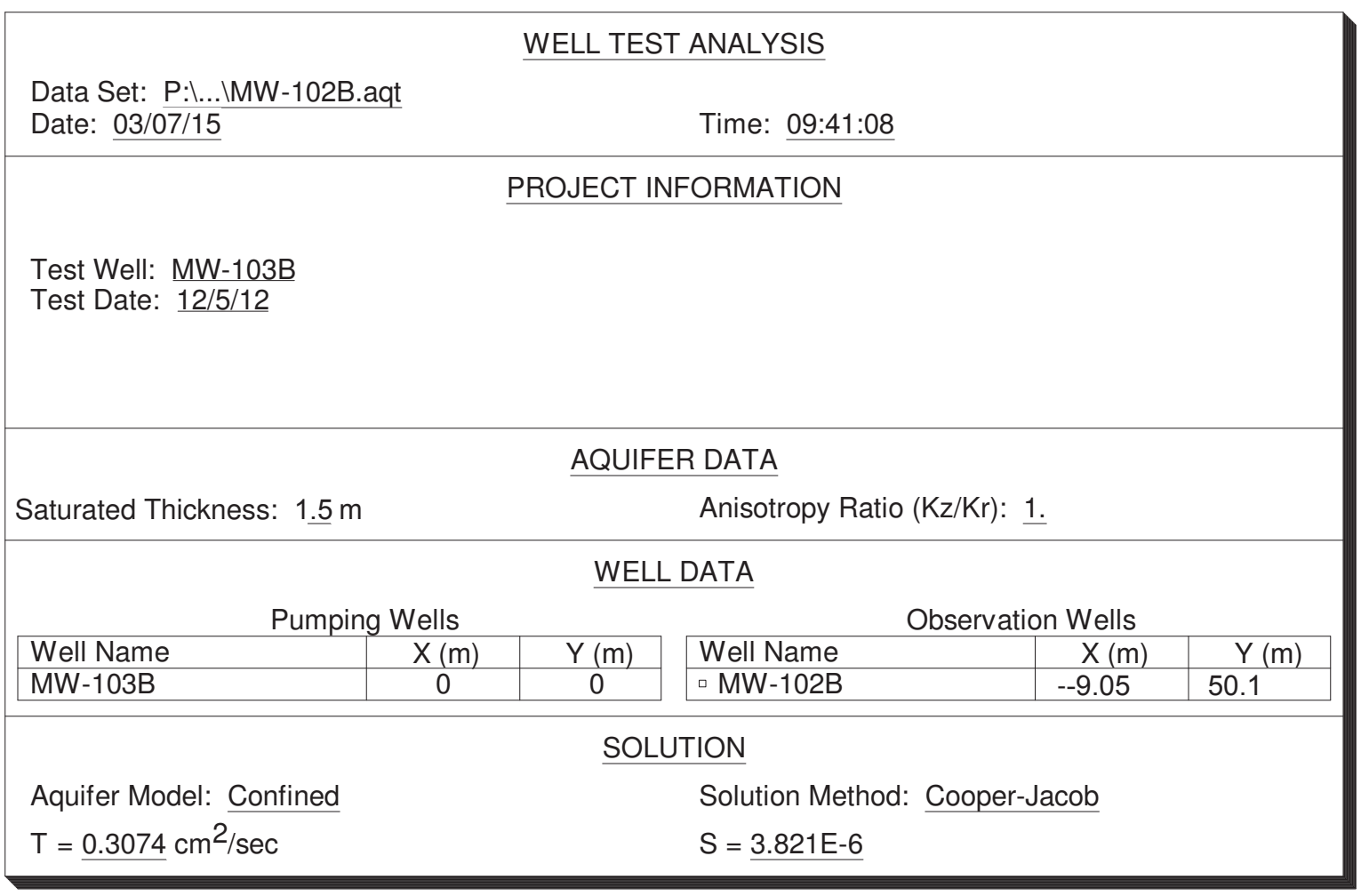

Figure C-6: MW-102B Pumping Test 


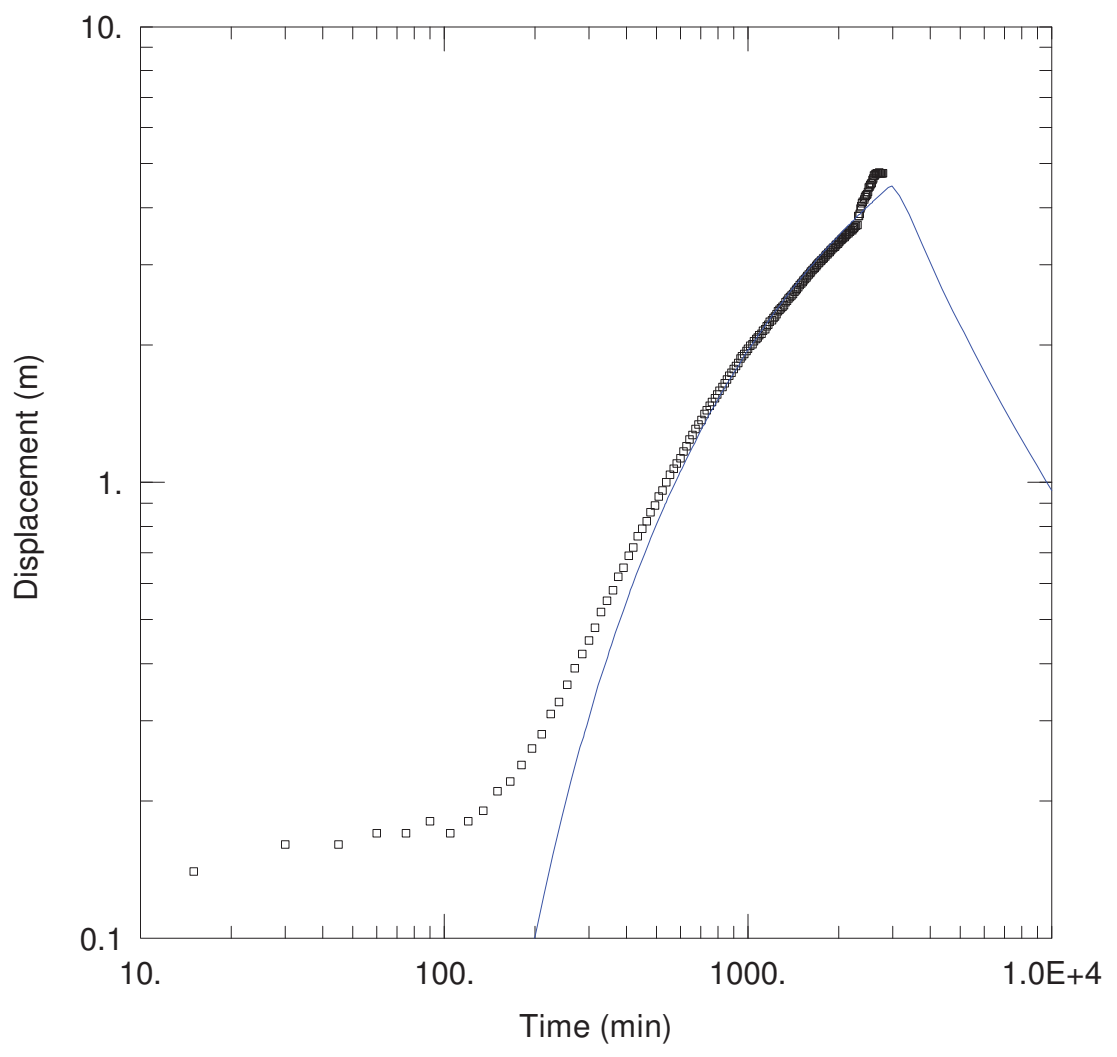

WELL TEST ANALYSIS

Data Set: P:I...MW-105B.aqt

Date: $03 / 07 / 15$

Time: 09:42:14

PROJECT INFORMATION

Test Well: MW-103B

Test Date: $12 / 5 / 12$

\section{AQUIFER DATA}

Saturated Thickness: $1.5 \mathrm{~m}$

Anisotropy Ratio (Kz/Kr): 1.

WELL DATA

Pumping Wells

\begin{tabular}{|l|c|c|}
\hline Well Name & $\mathrm{X}(\mathrm{m})$ & $\mathrm{Y}(\mathrm{m})$ \\
\hline MW-103B & 0 & 0 \\
\hline
\end{tabular}

Observation Wells

\begin{tabular}{|l|c|c|}
\hline Well Name & $X(m)$ & $Y(m)$ \\
\hline$\square$ MW-105B & 122.6 & 61.5 \\
\hline
\end{tabular}

\section{SOLUTION}

Aquifer Model: Confined

$\mathrm{T}=0.4061 \mathrm{~cm}^{2} / \mathrm{sec}$

$\mathrm{Sw}=0$.

$\mathrm{P}=\underline{2}$.

Step Test Model: Jacob-Rorabaugh Time $(\mathrm{t})=\underline{1} \cdot \mathrm{min}$
Solution Method: Theis (Step Test)

$\mathrm{S}=0.0002265$

$\mathrm{C}=$

$\mathrm{s}(\mathrm{t})=$

$W . E .=100 . \%(Q$ from last 


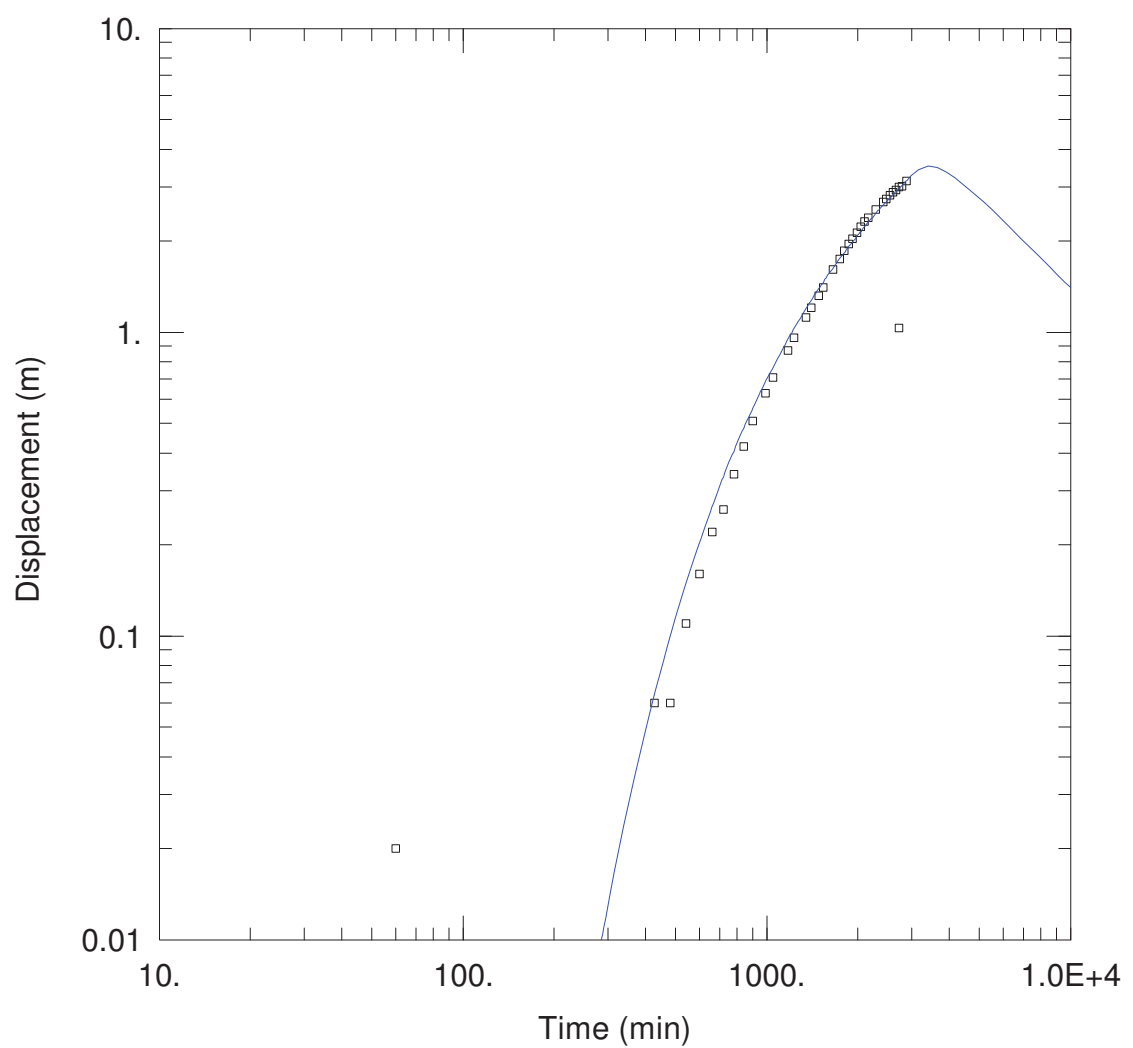

\begin{tabular}{|c|c|c|c|c|c|}
\hline \multicolumn{6}{|c|}{ WELL TEST ANALYSIS } \\
\hline $\begin{array}{l}\text { Data Set: } P:|\ldots| M W-107 \mathrm{~B} \\
\text { Date: } \underline{03 / 07 / 15}\end{array}$ & & \multicolumn{4}{|c|}{ Time: $\underline{09: 42: 58}$} \\
\hline \multirow{2}{*}{\multicolumn{6}{|c|}{$\begin{array}{l}\text { Test Well: } \mathrm{MW}-103 \mathrm{~B} \\
\text { Test Date: } \underline{12 / 5 / 12}\end{array}$}} \\
\hline & & & & & \\
\hline \multicolumn{6}{|c|}{ WELL DATA } \\
\hline \multicolumn{3}{|c|}{ Pumping Wells } & \multicolumn{3}{|c|}{ Observation Wells } \\
\hline Well Name & $X(m)$ & $Y(m)$ & Well Name & & $\mathrm{Y}(\mathrm{m})$ \\
\hline MW-103B & 0 & 0 & 口 MW-107B & 181 & -517 \\
\hline \multicolumn{6}{|c|}{$\underline{\text { SOLUTION }}$} \\
\hline Aquifer Model: Confined & \multicolumn{5}{|c|}{ Solution Method: Theis } \\
\hline $\begin{array}{l}\mathrm{T}=\underline{0.2528} \mathrm{~cm}^{2} / \mathrm{sec} \\
\mathrm{Kz} / \mathrm{Kr}=\underline{1 .}\end{array}$ & \multicolumn{5}{|c|}{$\begin{array}{l}\mathrm{S}=2.535 \mathrm{E}-5 \\
\mathrm{~b}=1.5 \mathrm{~m}\end{array}$} \\
\hline
\end{tabular}

Figure C-8: MW-107B Slug Test 


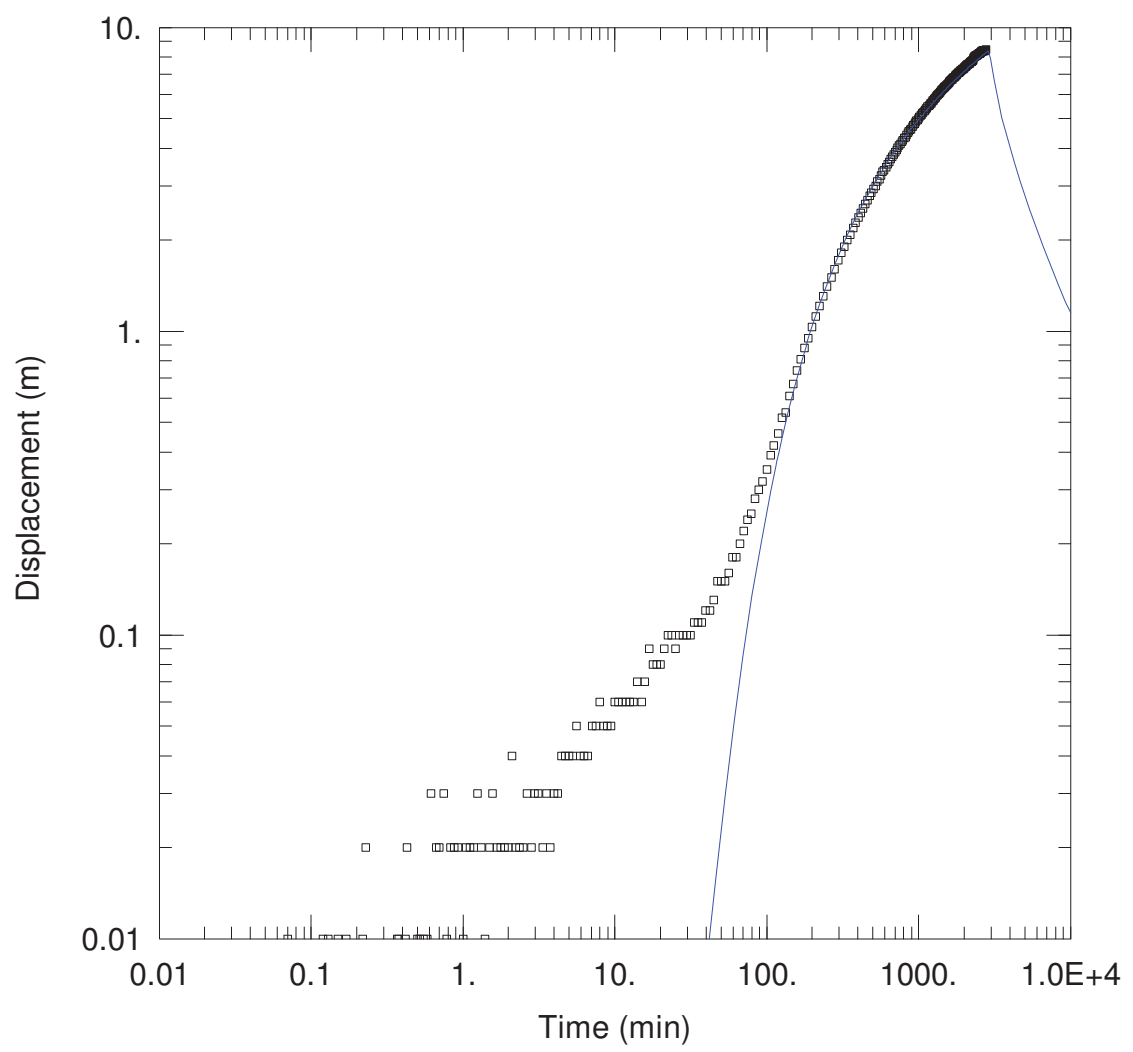

\begin{tabular}{|c|c|c|c|c|c|}
\hline \multicolumn{6}{|c|}{ WELL TEST ANALYSIS } \\
\hline $\begin{array}{l}\text { Data Set: } P:|\ldots| M W-116 \mathrm{~B} \\
\text { Date: } \underline{03 / 07 / 15}\end{array}$ & & \multicolumn{4}{|c|}{ Time: 09:43:22 } \\
\hline \multirow{2}{*}{\multicolumn{6}{|c|}{$\begin{array}{l}\text { Test Well: } \mathrm{MW}-103 \mathrm{~B} \\
\text { Test Date: } \underline{12 / 5 / 12}\end{array}$}} \\
\hline & & & & & \\
\hline \multicolumn{6}{|c|}{ WELL DATA } \\
\hline \multicolumn{3}{|c|}{ Pumping Wells } & \multicolumn{3}{|c|}{ Observation Wells } \\
\hline Well Name & $X(\mathrm{~m})$ & $Y(m)$ & Well Name & $X(\mathrm{~m})$ & $\mathrm{Y}(\mathrm{m})$ \\
\hline MW-103B & 0 & 0 & - MW-116B & 103.4 & -60.12 \\
\hline \multicolumn{6}{|c|}{ SOLUTION } \\
\hline Aquifer Model: Confined & \multicolumn{5}{|c|}{ Solution Method: Theis } \\
\hline $\begin{array}{l}\mathrm{T}=0.3502 \mathrm{~cm}^{2} / \mathrm{sec} \\
\mathrm{Kz} / \mathrm{Kr}=\underline{1 .}\end{array}$ & \multicolumn{5}{|c|}{$\begin{aligned} S & =9.337 \mathrm{E}-5 \\
b & =1.5 \mathrm{~m}\end{aligned}$} \\
\hline
\end{tabular}

Figure C-9: MW-116B Slug Test 


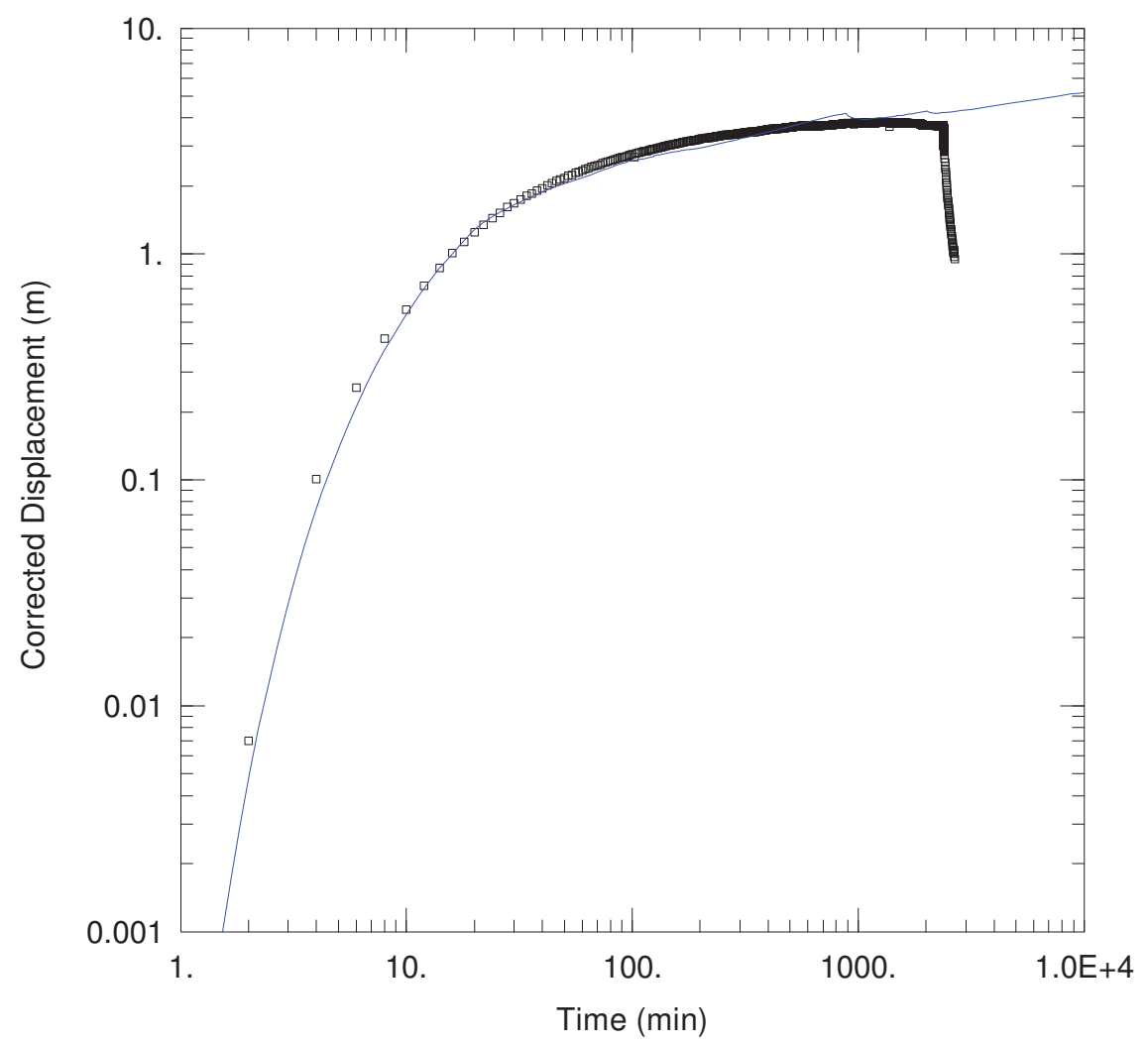

WELL TEST ANALYSIS

Data Set: P:I...IOW-112B.aqt

Date: $\underline{03 / 07 / 15}$

Time: $09: 46: 43$

PROJECT INFORMATION

Test Well: MW-112

Test Date: 10/8/12

WELL DATA

Pumping Wells

Well Name

\begin{tabular}{c|c}
\hline $\mathrm{X}(\mathrm{m})$ & $\mathrm{Y}(\mathrm{m})$ \\
\hline 0 & 0
\end{tabular}

Observation Wells

MW-112

\section{SOLUTION}

Aquifer Model: Unconfined

Solution Method: Theis

$\mathrm{T}=0.2884 \mathrm{~cm}^{2} / \mathrm{sec}$

$\mathrm{S}=8.449 \mathrm{E}-5$

$\mathrm{Kz} / \mathrm{Kr}=1$.

$\mathrm{b}=19.6 \mathrm{~m}$

Figure C-10: OW-112B Slug Test 


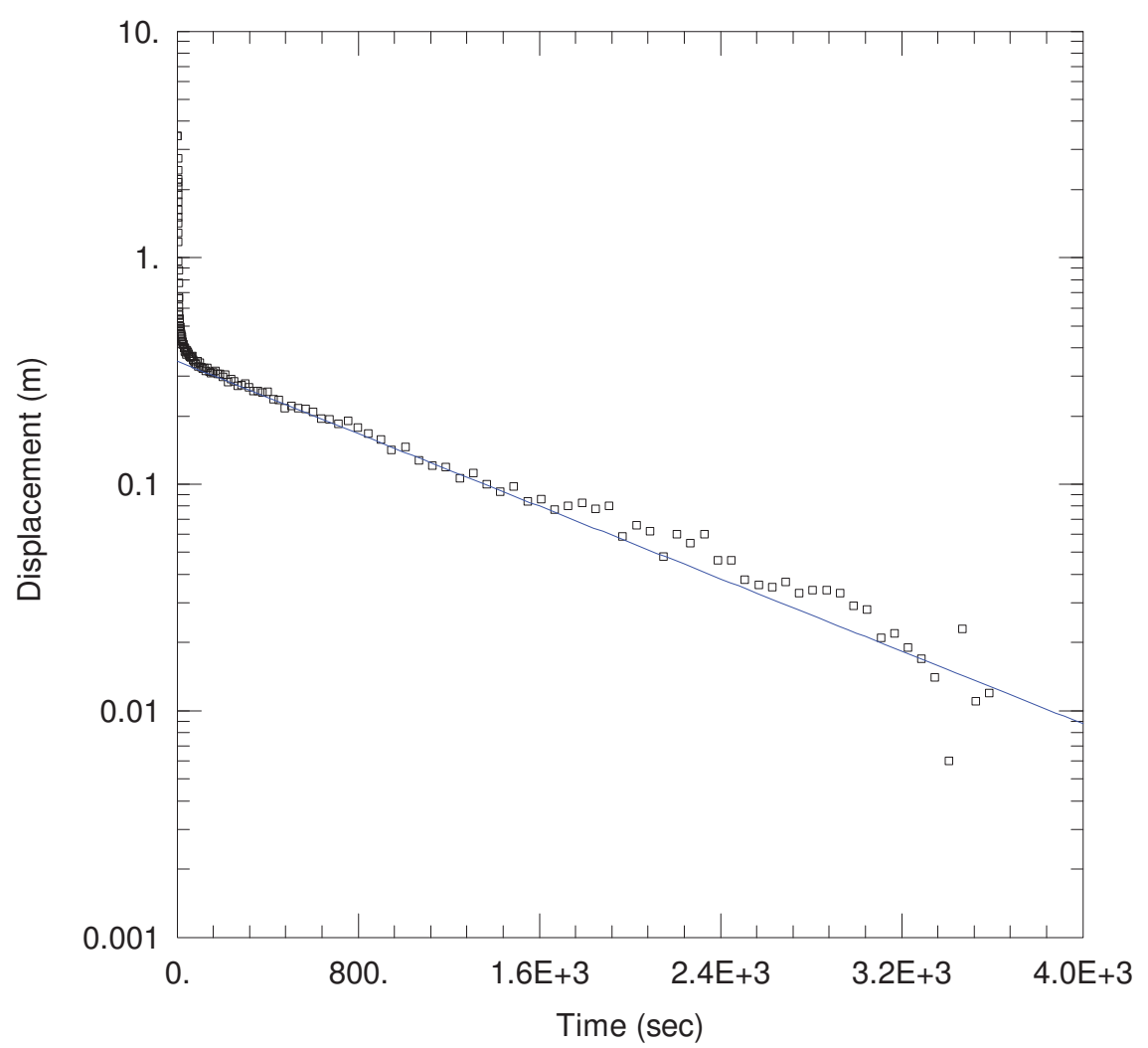

WELL TEST ANALYSIS

Data Set: P:I...112-10A Slug test.aqt Date: $\underline{03 / 07 / 15}$

Time: 09:23:19

PROJECT INFORMATION

Well: 12-10A Test

Date: $11 / 26 / 12$

\section{AQUIFER DATA}

Saturated Thickness: $35.3 \mathrm{~m}$

Anisotropy Ratio (Kz/Kr): 1.

WELL DATA (12-10A)

Initial Displacement: $1.05 \mathrm{~m}$

Total Well Penetration Depth: $4.2 \mathrm{~m}$

Casing Radius: $\underline{0.025} \mathrm{~m}$

Static Water Column Height: $4.2 \mathrm{~m}$

Screen Length: $4.2 \mathrm{~m}$

Well Radius: $0.05 \mathrm{~m}$

Gravel Pack Porosity: $\underline{0.35}$

\section{SOLUTION}

Aquifer Model: Unconfined

Solution Method: Bouwer-Rice

$\mathrm{K}=4.032 \mathrm{E}-5 \mathrm{~cm} / \mathrm{sec}$

$\mathrm{y} 0=\underline{0.1064} \mathrm{~m}$

Figure C-11: 12-10A Slug Test 


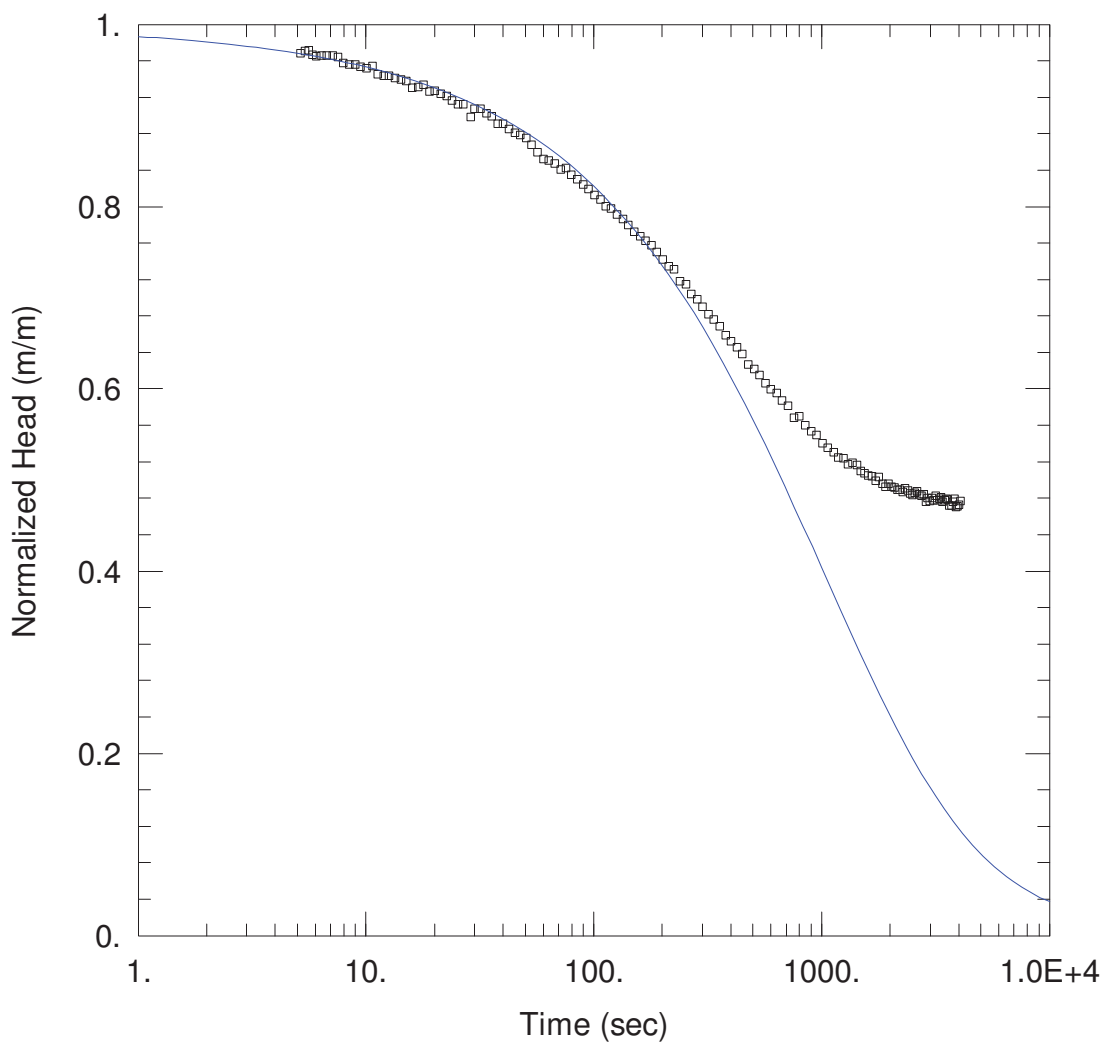

WELL TEST ANALYSIS

Data Set: $P: \backslash \ldots \backslash P-1(50)$ Slug Test_dbtRevision.aqt Date: $03 / 07 / 15$ Time: 09:21:54

PROJECT INFORMATION

Test Well: PZ-1(50)

Test Date: $\underline{11 / 26 / 12}$

\section{AQUIFER DATA}

Saturated Thickness: $66.7 \mathrm{~m}$

Anisotropy Ratio (Kz/Kr): 1.

WELL DATA (P-1(50))

Initial Displacement: $1.14 \mathrm{~m}$

Total Well Penetration Depth: 14.m

Casing Radius: $0.025 \mathrm{~m}$

Static Water Column Height: $16 \mathrm{~m}$

Screen Length: 3 . m

Well Radius: $0.05 \mathrm{~m}$

Gravel Pack Porosity: $\underline{0}$.

\section{SOLUTION}

Aquifer Model: Confined

Solution Method: Cooper-Bredehoeft-Papadopulos

$\mathrm{T}=\underline{0.005129} \mathrm{~cm}^{2} / \mathrm{sec}$

$S=\underline{0.007049}$

Figure C-12: P-1(50) Pumping Test 


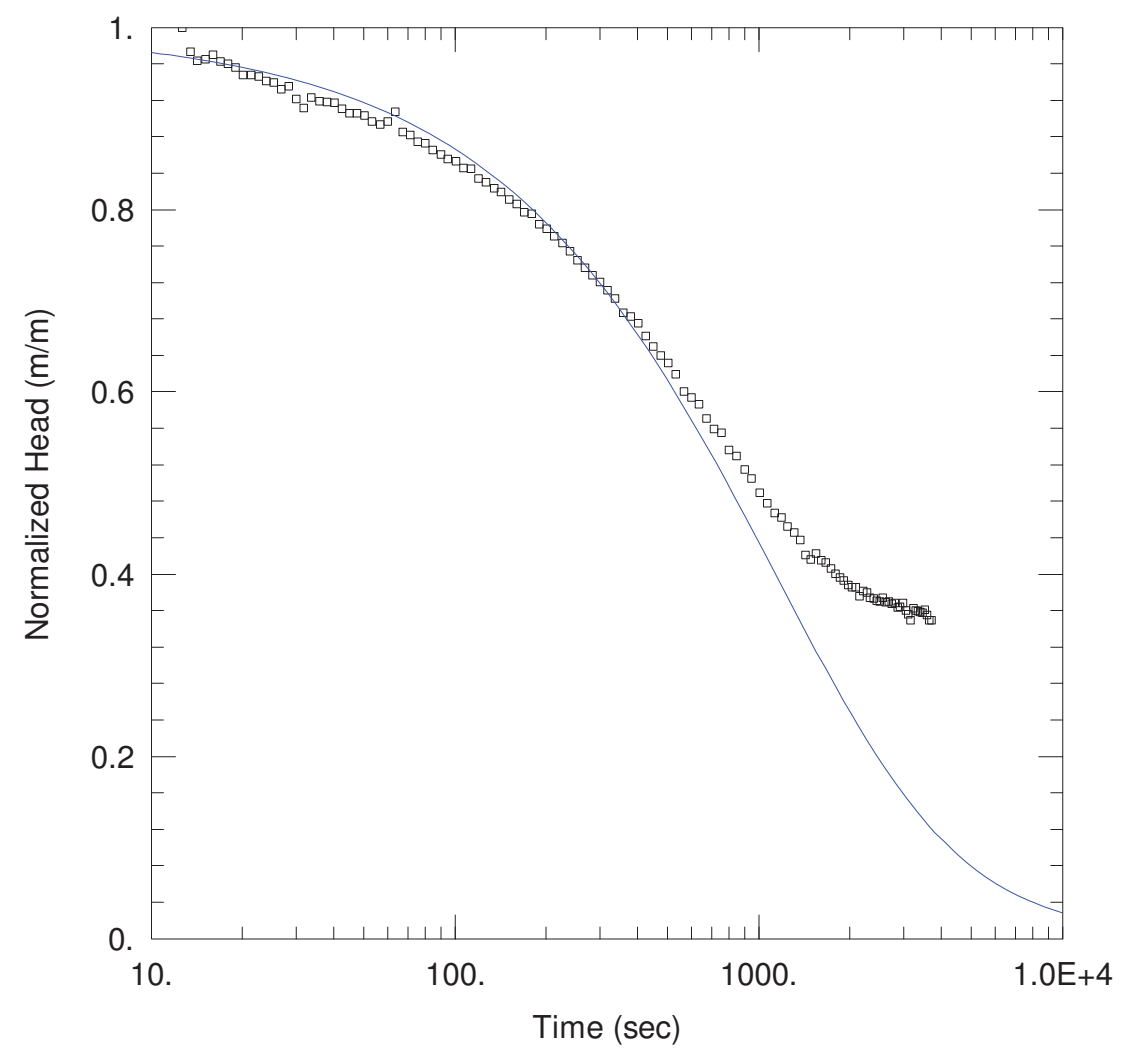

WELL TEST ANALYSIS

Data Set: P:I...P-1(150) Slug Test_dbt revision.aqt Date: $\underline{03 / 07 / 15}$ Time: 09:22:33

PROJECT INFORMATION

Test Well: $\underline{P-1(150)}$

Test Date: $11 / 26 / 12$

\section{AQUIFER DATA}

Saturated Thickness: $\underline{64} \mathrm{~m}$

Anisotropy Ratio (Kz/Kr): 1.

WELL DATA (P-1(150))

Static Water Column Height: $\underline{42.7 \mathrm{~m}}$

Screen Length: $3 . \mathrm{m}$

Well Radius: $0.25 \mathrm{~m}$

Gravel Pack Porosity: $\underline{0 .}$

Total Well Penetration Depth: $42.6 \mathrm{~m}$

Casing Radius: $\underline{0.025} \mathrm{~m}$

\section{SOLUTION}

Aquifer Model: $\underline{\text { Confined }}$

Solution Method: Cooper-Bredehoeft-Papadopulos

$\mathrm{T}=\underline{0.007057} \mathrm{~cm}^{2} / \mathrm{sec}$

$S=0.001$ 


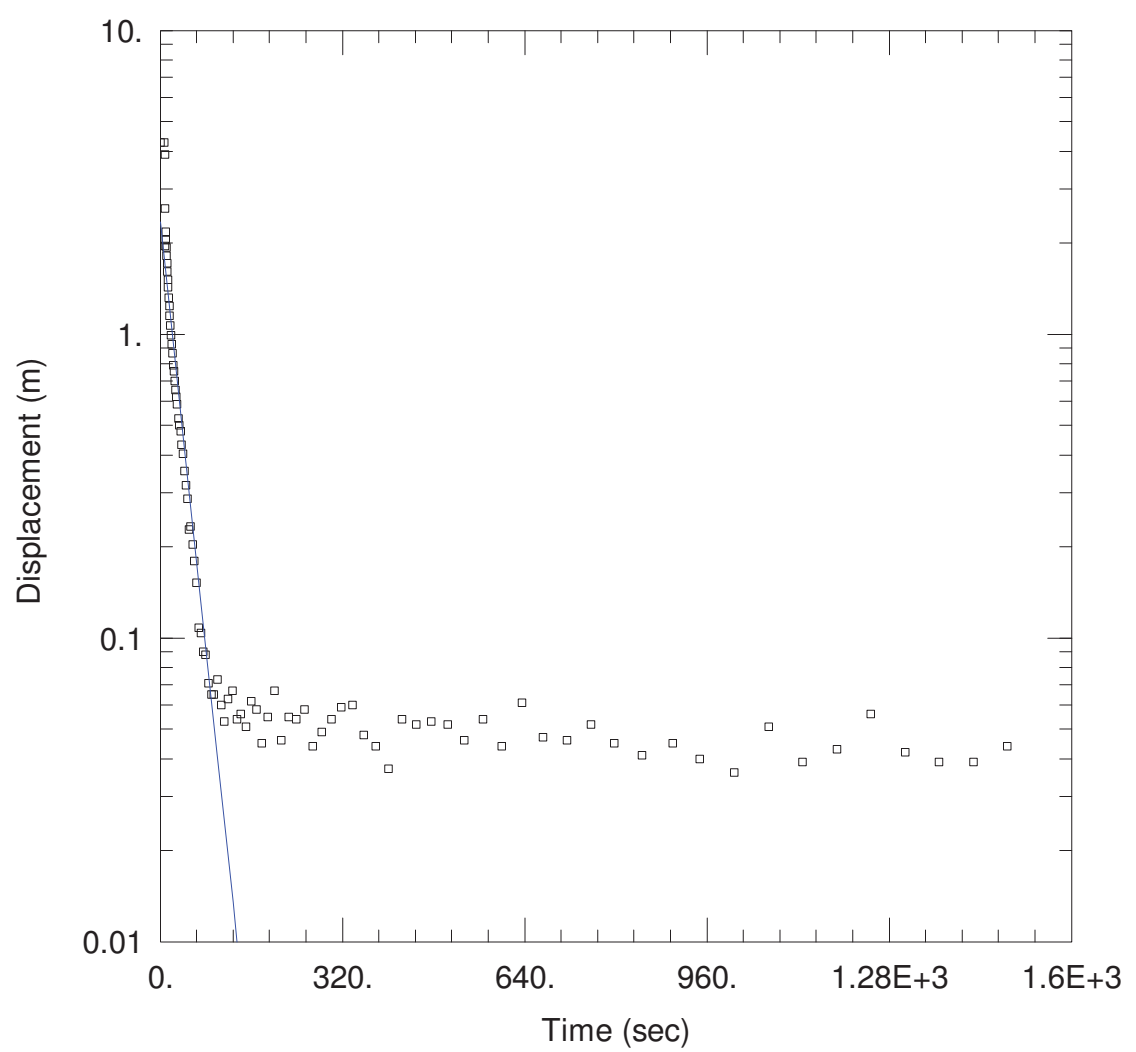

WELL TEST ANALYSIS

Data Set: P:I..IP-1(220) Slug Test.aqt

Date: $\underline{03 / 07 / 15}$

Time: 09:22:59

PROJECT INFORMATION

Test Well: P-1(220)

Test Date: $11 / 26 / 12$

\section{AQUIFER DATA}

Saturated Thickness: $65 \mathrm{~m}$

Anisotropy Ratio (Kz/Kr): 1.

WELL DATA (P-1(220))

Initial Displacement: $1.3 \mathrm{~m}$

Total Well Penetration Depth: $58.8 \mathrm{~m}$

Casing Radius: $\underline{0.025} \mathrm{~m}$

Static Water Column Height: $\underline{58.8 m}$

Screen Length: 3. m

Well Radius: $0.05 \mathrm{~m}$

Gravel Pack Porosity: 0 .

\section{SOLUTION}

Aquifer Model: Unconfined

Solution Method: Bouwer-Rice

$\mathrm{K}=0.001431 \mathrm{~cm} / \mathrm{sec}$

y0 $=0.71 \mathrm{~m}$

Figure C-14: P-1(220) Slug Test 


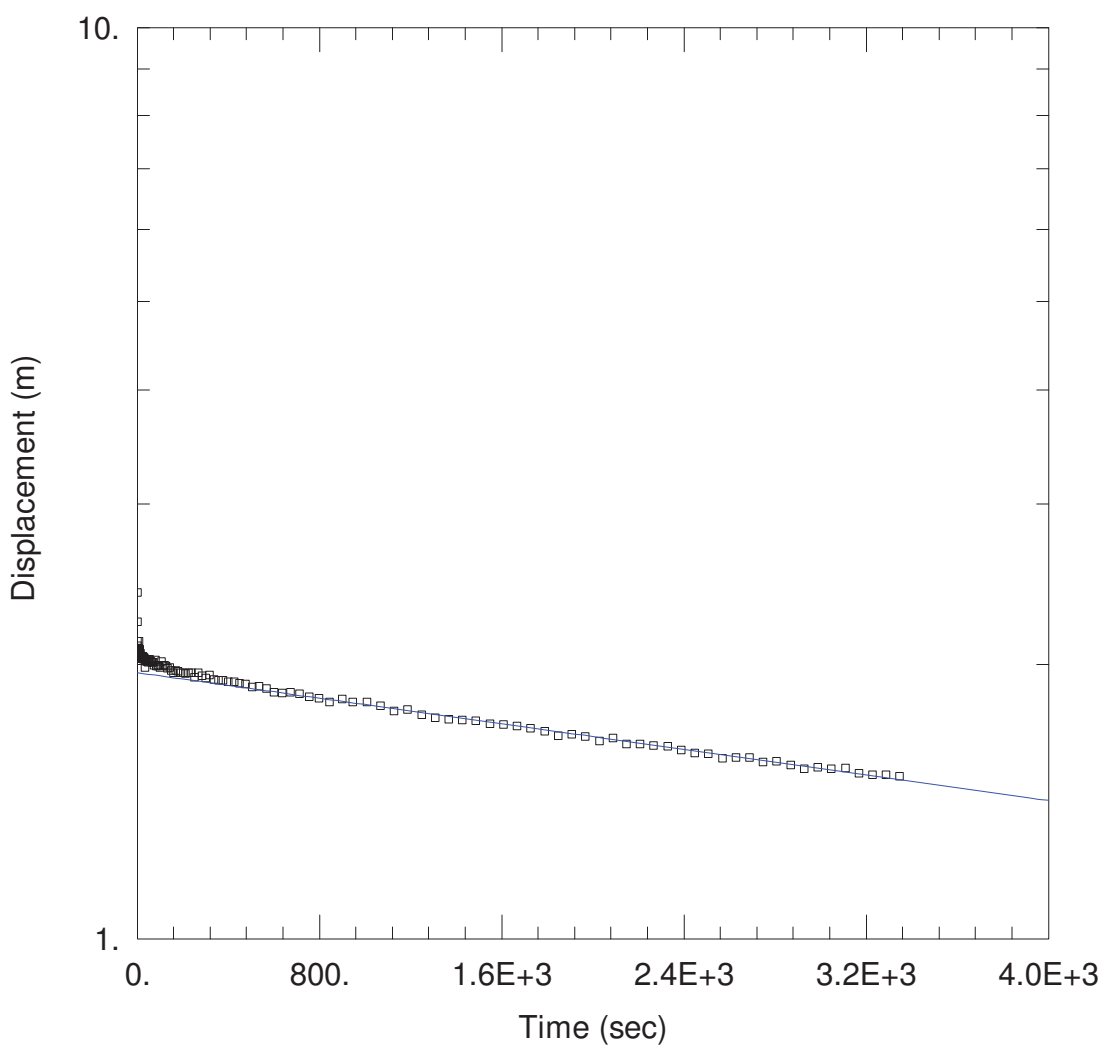

\begin{tabular}{|c|c|}
\hline \multicolumn{2}{|c|}{ WELL TEST ANALYSIS } \\
\hline $\begin{array}{l}\text { Data Set: } P: 1 . . . M W \text {-101.aqt } \\
\text { Date: } \underline{03 / 07 / 15}\end{array}$ & Time: 09:15:04 \\
\hline \multirow{2}{*}{\multicolumn{2}{|c|}{$\begin{array}{l}\text { Test Well: } \frac{M W-101}{10 / 23 / 12} \\
\text { Test Date: }\end{array}$}} \\
\hline & \\
\hline \multicolumn{2}{|c|}{ AQUIFER DATA } \\
\hline Saturated Thickness: $\underline{3.6 \mathrm{~m}}$ & Anisotropy Ratio (Kz/Kr): 1 . \\
\hline \multicolumn{2}{|c|}{ WELL DATA (MW-101) } \\
\hline $\begin{array}{l}\text { Initial Displacement: } 0.73 \mathrm{~m} \\
\text { Total Well Penetration Depth: } \underline{3.6} \mathrm{~m} \\
\text { Casing Radius: } \underline{0.025} \mathrm{~m}\end{array}$ & $\begin{array}{l}\text { Static Water Column Height: } \underline{3.6 \mathrm{~m}} \\
\text { Screen Length: } \underline{3.0 \mathrm{~m}} \\
\text { Well Radius: } \underline{0.05 \mathrm{~m}} \\
\text { Gravel Pack Porosity: } \underline{0 .}\end{array}$ \\
\hline \multicolumn{2}{|c|}{ SOLUTION } \\
\hline $\begin{array}{l}\text { Aquifer Model: Unconfined } \\
\mathrm{K}=\underline{2.391 \mathrm{E}-6 \mathrm{~cm} / \mathrm{sec}}\end{array}$ & $\begin{array}{l}\text { Solution Method: Bouwer-Rice } \\
\text { y0 }=\underline{0.6 \mathrm{~m}}\end{array}$ \\
\hline
\end{tabular}

Figure C-15: MW-101 Slug Test 


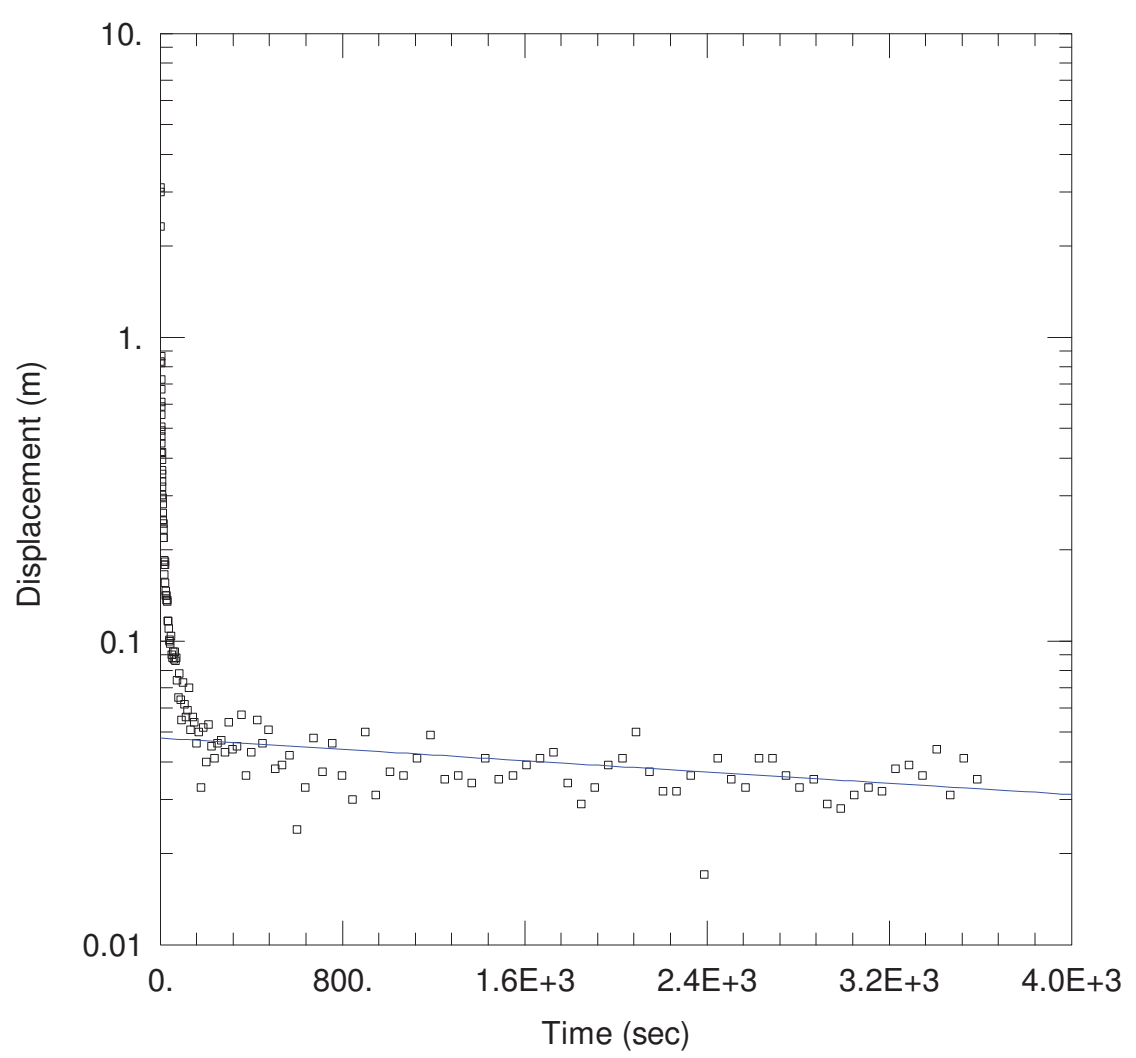

\begin{tabular}{|c|c|}
\hline \multicolumn{2}{|c|}{ WELL TEST ANALYSIS } \\
\hline $\begin{array}{l}\text { Data Set: } P: 1 \ldots \mid M W-103 a . a q t \\
\text { Date: } \underline{03 / 07 / 15}\end{array}$ & Time: $\underline{09: 16: 18}$ \\
\hline \multirow{2}{*}{\multicolumn{2}{|c|}{$\begin{array}{l}\text { Test Well: } \frac{M W-103 a}{10 / 16 / 12} \\
\text { Test Date: }\end{array}$}} \\
\hline & \\
\hline \multicolumn{2}{|c|}{$\underline{\text { AQUIFER DATA }}$} \\
\hline Saturated Thickness: $\underline{8.8 \mathrm{~m}}$ & Anisotropy Ratio (Kz/Kr): 1 . \\
\hline \multicolumn{2}{|c|}{ WELL DATA (MW-103a) } \\
\hline $\begin{array}{l}\text { Initial Displacement: } 0.9 \mathrm{~m} \\
\text { Total Well Penetration Depth: } \underline{3.1} \mathrm{n} \\
\text { Casing Radius: } \underline{0.025 \mathrm{~m}}\end{array}$ & $\begin{array}{l}\text { Static Water Column Height: } \underline{3.2 \mathrm{~m}} \\
\text { Screen Length: } \underline{3.0 \mathrm{~m}} \\
\text { Well Radius: } 0.05 \mathrm{~m} \\
\text { Gravel Pack Porosity: } \underline{0 .}\end{array}$ \\
\hline \multicolumn{2}{|c|}{ SOLUTION } \\
\hline Aquifer Model: Unconfined & Solution Method: Bouwer-Rice \\
\hline 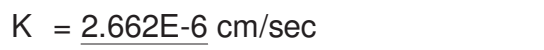 & $\mathrm{y} 0=\underline{0.015 \mathrm{~m}}$ \\
\hline
\end{tabular}

Figure C-16: MW-103a Slug Test 


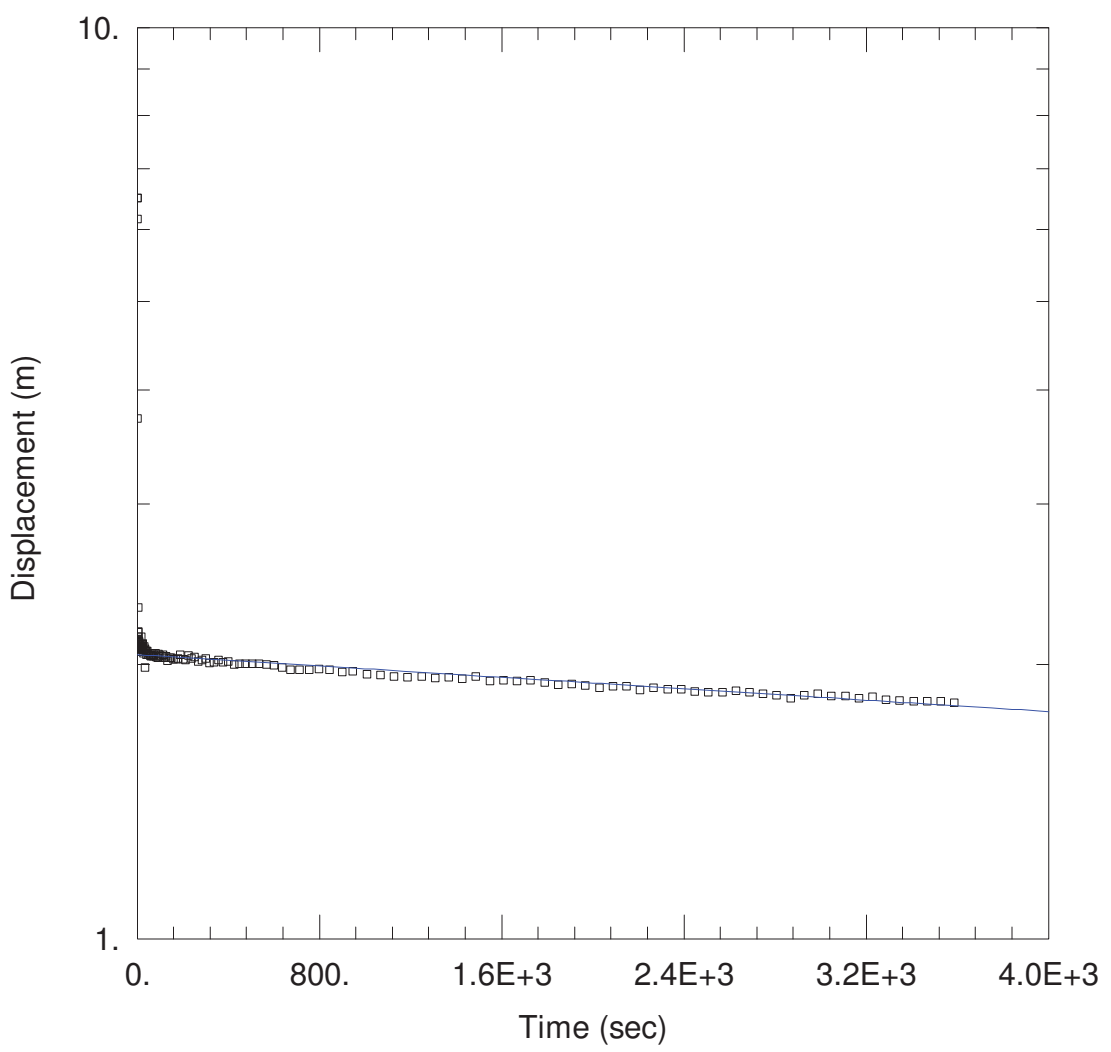

\begin{tabular}{|c|c|}
\hline \multicolumn{2}{|c|}{ WELL TEST ANALYSIS } \\
\hline $\begin{array}{l}\text { Data Set: } P: 1 \ldots \mid M W-103 c . \text { aqt } \\
\text { Date: } \underline{03 / 07 / 15}\end{array}$ & Time: $\underline{09: 16: 57}$ \\
\hline \multicolumn{2}{|c|}{ PROJECT INFORMATION } \\
\hline 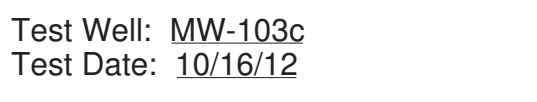 & \\
\hline \multicolumn{2}{|c|}{$\underline{\text { AQUIFER DATA }}$} \\
\hline Saturated Thickness: $\underline{1.5 \mathrm{~m}}$ & Anisotropy Ratio (Kz/Kr): 1 . \\
\hline \multicolumn{2}{|c|}{ WELL DATA (MW-103c) } \\
\hline $\begin{array}{l}\text { Initial Displacement: } 2.0 \mathrm{~m} \\
\text { Total Well Penetration Depth: } \underline{1.5} \mathrm{~m} \\
\text { Casing Radius: } \underline{0.025} \mathrm{~m}\end{array}$ & $\begin{array}{l}\text { Static Water Column Height: } \underline{5.8 \mathrm{~m}} \\
\text { Screen Length: } 1.5 \mathrm{~m} \\
\text { Well Radius: } 0.05 \mathrm{~m} \\
\text { Gravel Pack Porosity: } \underline{0 .}\end{array}$ \\
\hline \multicolumn{2}{|c|}{ SOLUTION } \\
\hline Aquifer Model: Confined & Solution Method: Bouwer-Rice \\
\hline 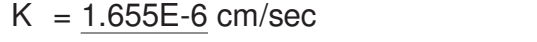 & $\mathrm{y} 0=\underline{0.62} \mathrm{~m}$ \\
\hline
\end{tabular}

Figure C-17: MW-103c Slug Test 


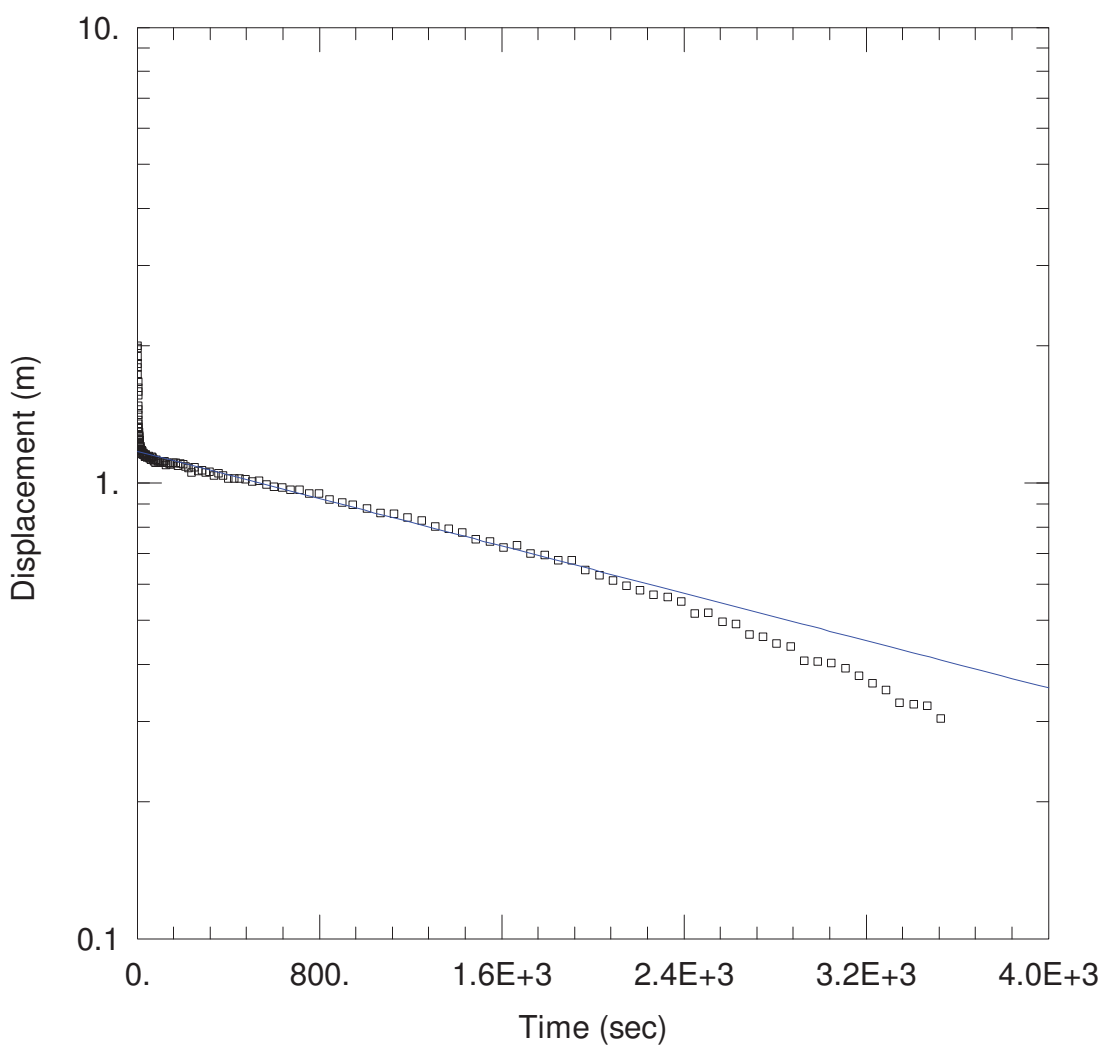

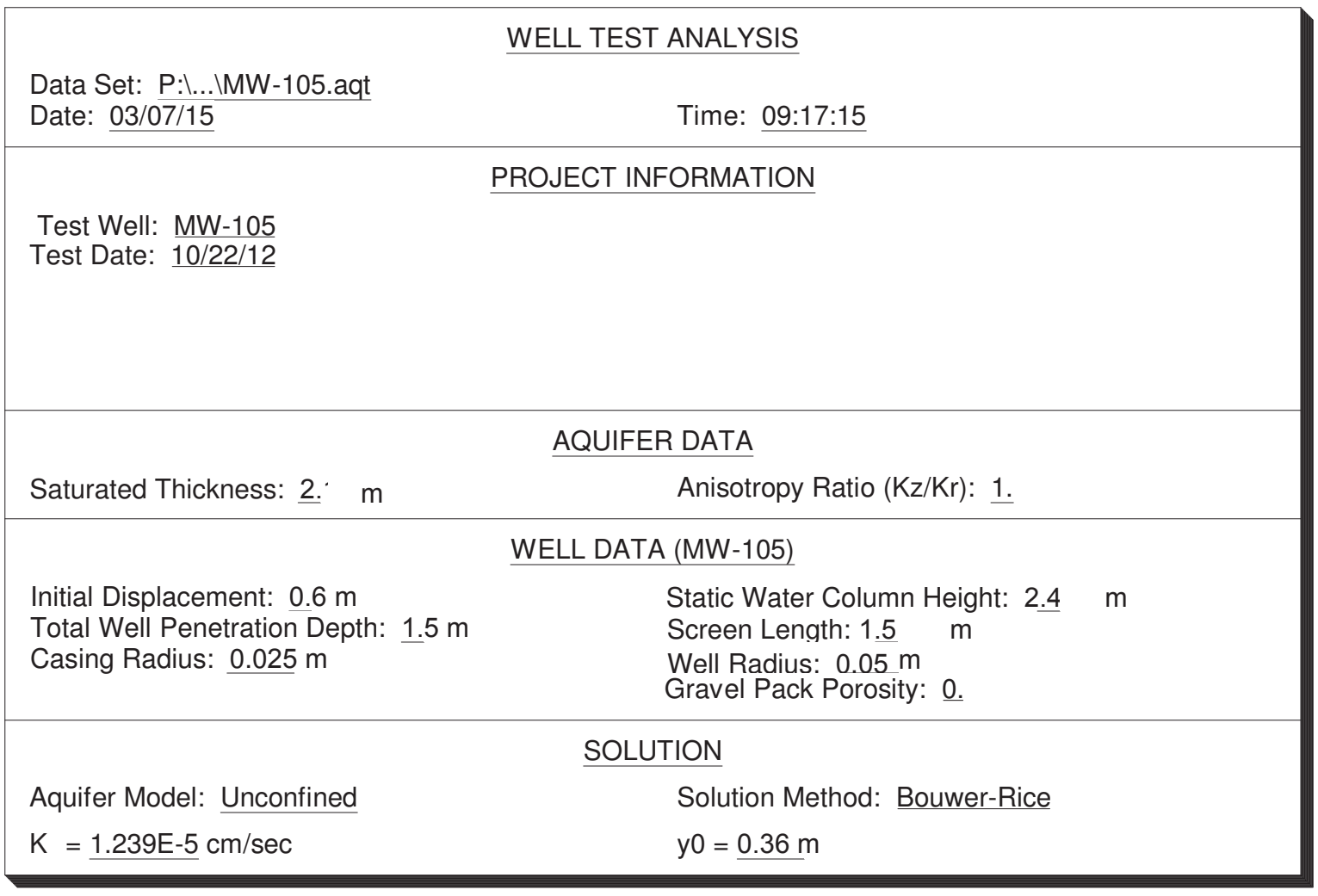

Figure C-18: MW-105 Slug Test 


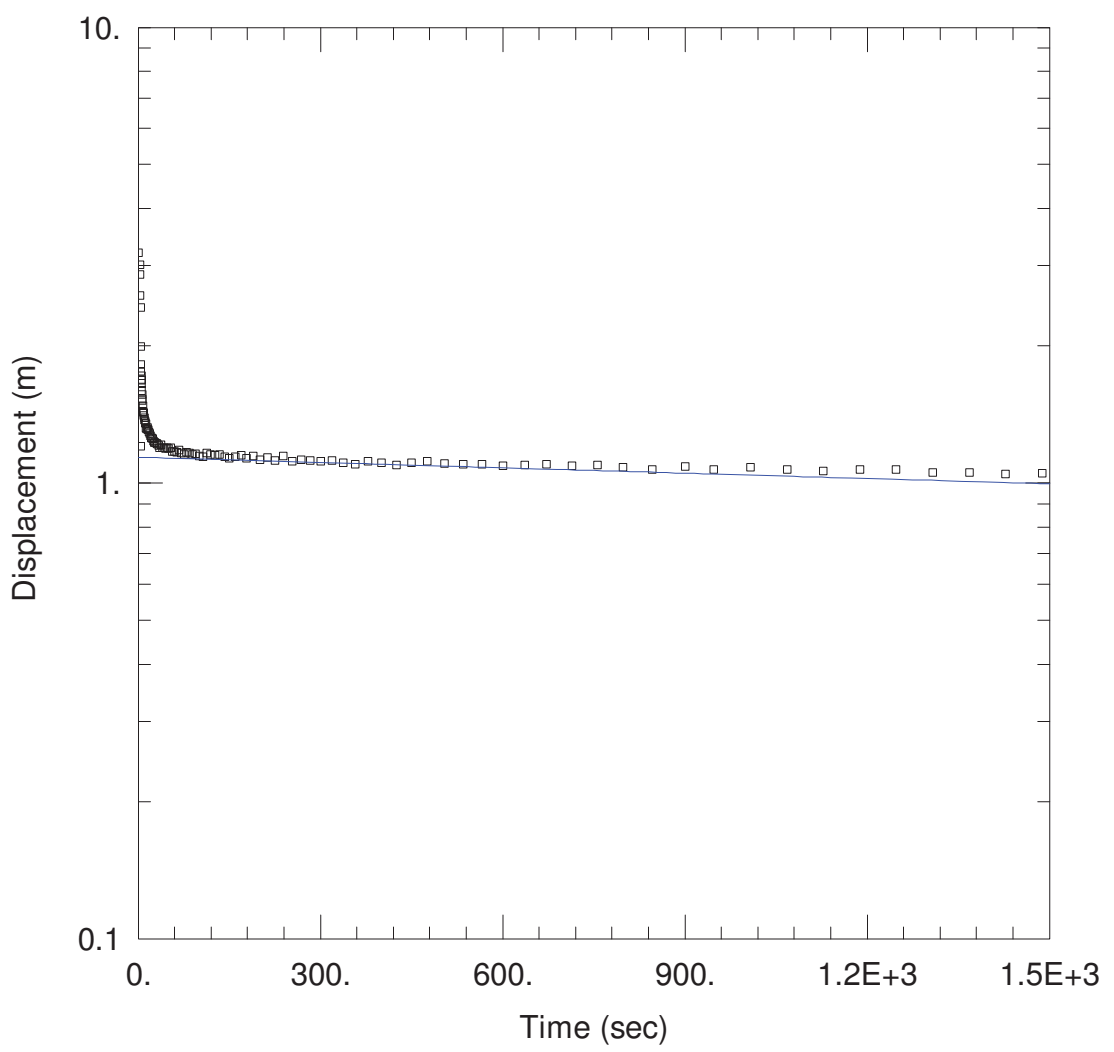

WELL TEST ANALYSIS

Data Set: P:I...MW-107a.aqt

Date: $\underline{03 / 07 / 15}$

Time: 09:17:58

PROJECT INFORMATION

Test Well: MW-107a

Test Date: 10/22/12

\section{AQUIFER DATA}

Saturated Thickness: $\underline{18} \mathrm{~m}$

Anisotropy Ratio (Kz/Kr): 1.

WELL DATA (MW-107a)

Static Water Column Height: 3. m

Screen Length: 3. m

Well Radius: $0.05 \mathrm{~m}$

Gravel Pack Porosity: $\underline{0 .}$

Total Well Penetration Depth: $3 \mathrm{~m}$

Casing Radius: $\underline{0.025} \mathrm{~m}$

SOLUTION

Aquifer Model: Unconfined

Solution Method: Bouwer-Rice

$\mathrm{K}=2.166 \mathrm{E}-6 \mathrm{~cm} / \mathrm{sec}$

y0 $=0.35 \mathrm{~m}$

Figure C-19: MW-107a Slug Test 


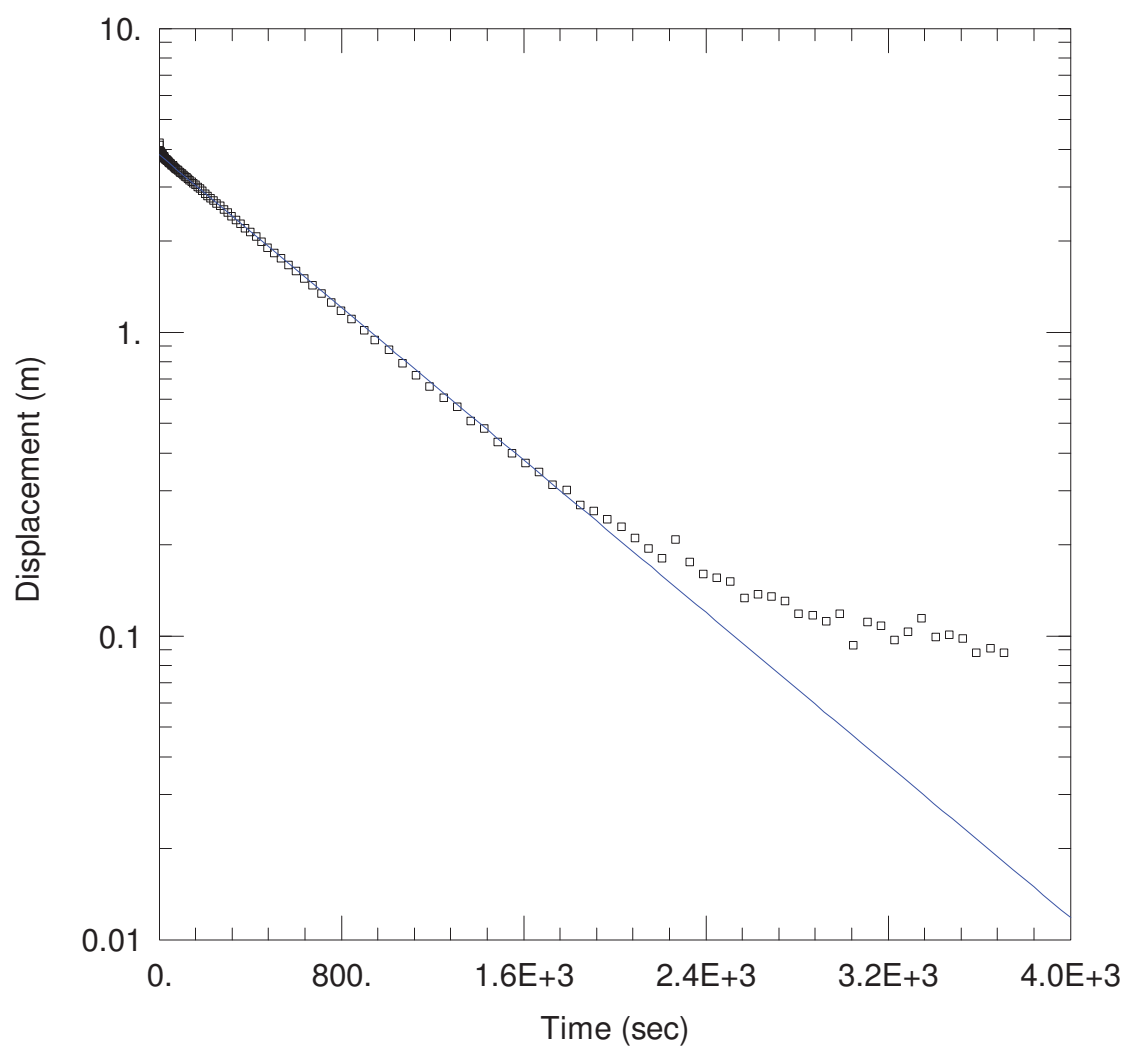

WELL TEST ANALYSIS

Data Set: P:I...MW-107b.aqt

Date: $\underline{03 / 07 / 15}$

Time: 09:18:16

PROJECT INFORMATION

Test Well: MW-107b

Test Date: 10/22/12

\section{AQUIFER DATA}

Saturated Thickness: 1. m

Anisotropy Ratio (Kz/Kr): 1.

WELL DATA (MW-107b)

Static Water Column Height: 22.m

Screen Length: $1 . \mathrm{m}$

Initial Displacement: $1.3 \mathrm{~m}$

Total Well Penetration Depth: $1 . \mathrm{m}$

Well Radius: $0.05 \mathrm{~m}$

Casing Radius: $0.025 \mathrm{~m}$

SOLUTION

Aquifer Model: Confined

Solution Method: Bouwer-Rice

$\mathrm{K}=9.294 \mathrm{E}-5 \mathrm{~cm} / \mathrm{sec}$

y0 $=1.17 \mathrm{~m}$

Figure C-20: MW-107b Slug Test 


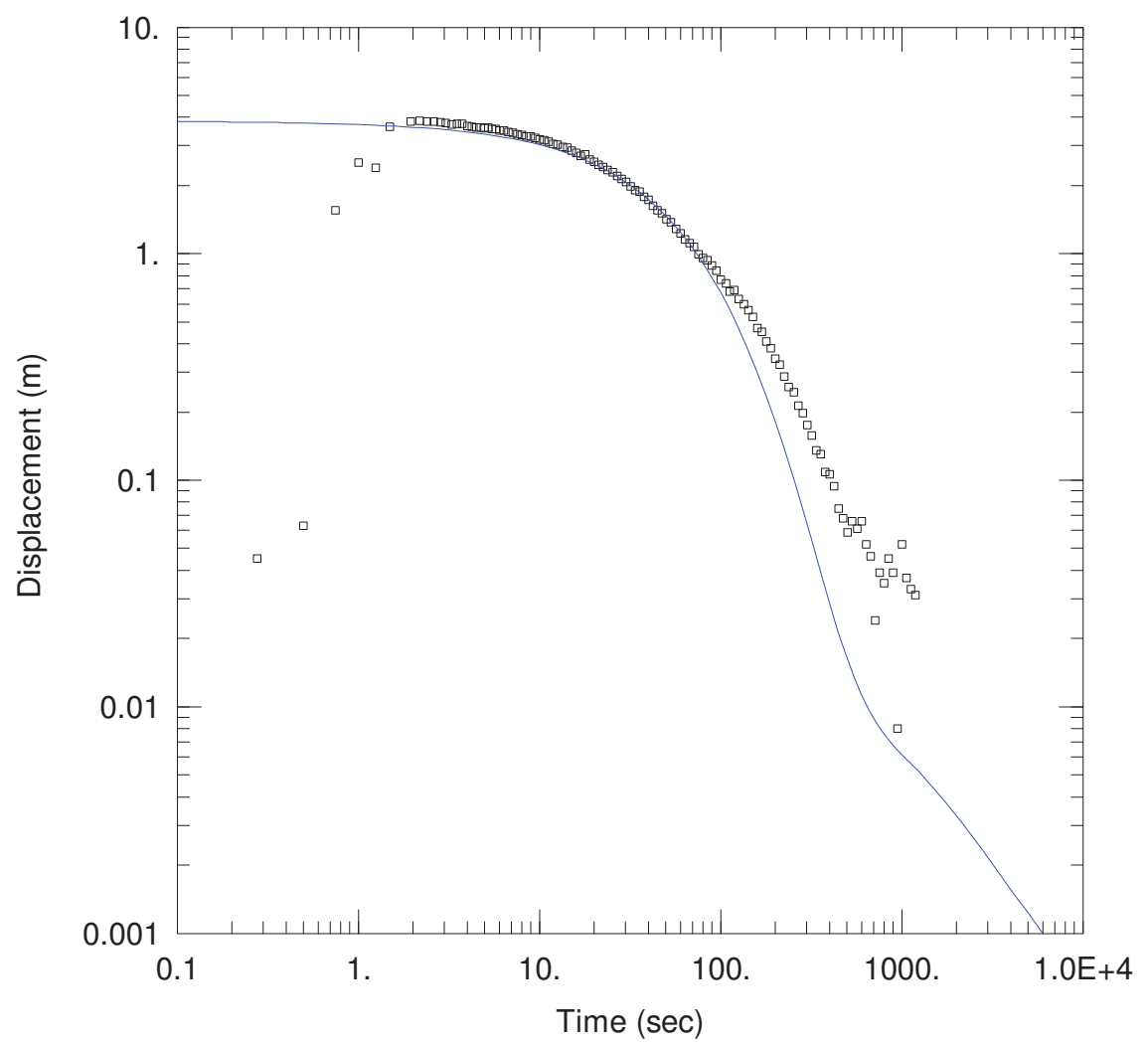

WELL TEST ANALYSIS

Data Set: P:I...MMW-107c.aqt

Date: $\underline{03 / 07 / 15}$

Time: 09:18:42

PROJECT INFORMATION

Test Well: MW-107c

Test Date: $10 / 22 / 12$

AQUIFER DATA

Saturated Thickness: $\underline{11 . \mathrm{m}}$

WELL DATA (MW-107c)

Static Water Column Height: $36 \mathrm{~m}$

$\begin{array}{ll}\text { Initial Displacement: } 1.2 \mathrm{~m} & \text { Static Water Column } \\ \text { Total Well Penetration Depth: } 35.4 \mathrm{~m} & \text { Screen Length: } 3 . \mathrm{m} \\ \text { Casing Radius: } 0.025 \mathrm{~m} & \text { Well Radius: } 0.05 \mathrm{~m}\end{array}$

Casing Radius: $\underline{0.025} \mathrm{~m}$

Well Radius: $\underline{0.05 \mathrm{~m}}$

SOLUTION

Aquifer Model: $\underline{\text { Confined }}$

Solution Method: KGS Model

$\mathrm{Kr}=0.000851 \mathrm{~cm} / \mathrm{sec}$

Ss $=\underline{0.008 \mathrm{ft}}$

$\mathrm{Kz} / \mathrm{Kr}=1$.

Figure C-21: MW-107c Slug Test 


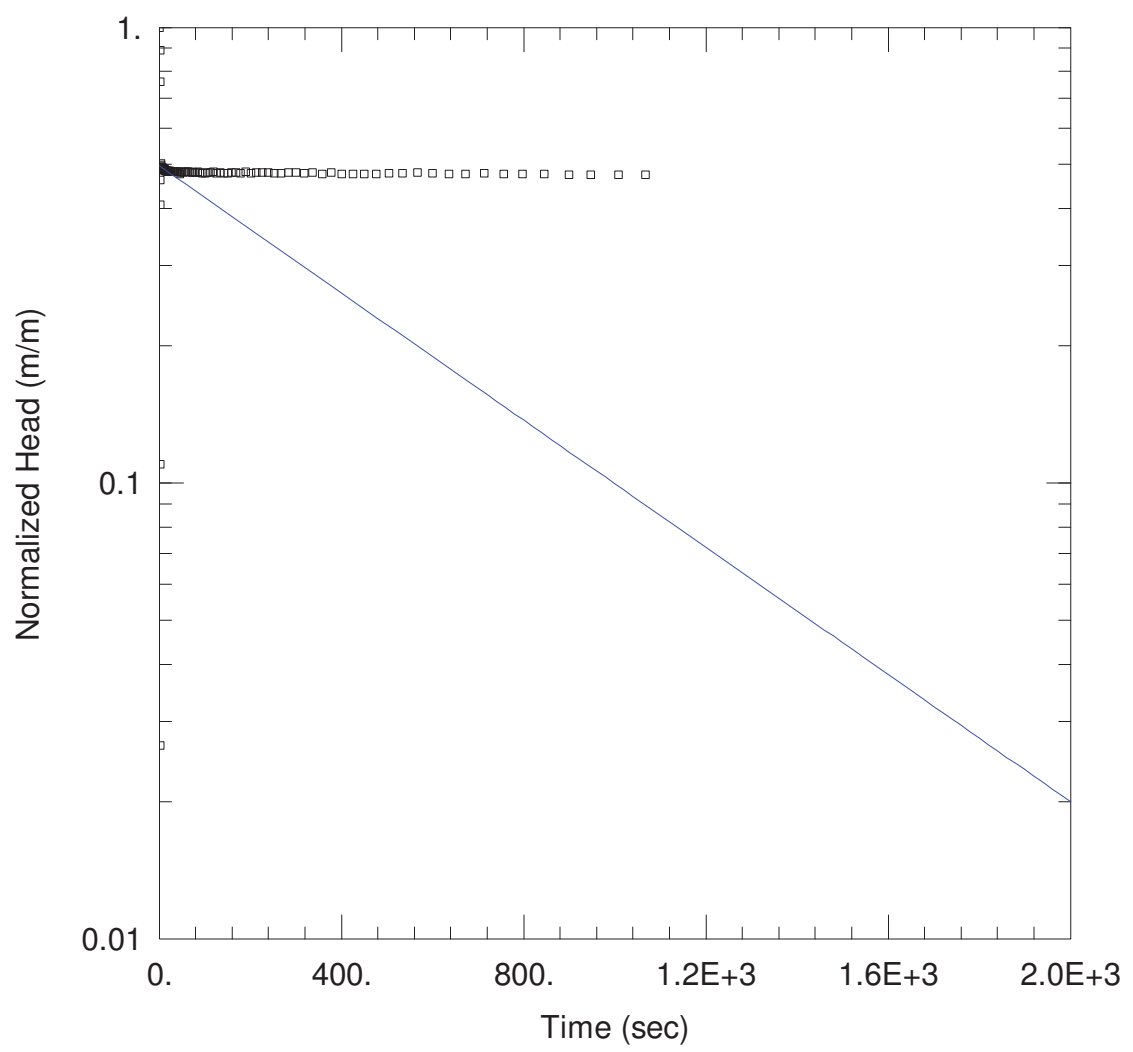

WELL TEST ANALYSIS

Data Set: P:I...MMW-110.aqt

Date: $\underline{03 / 07 / 15}$

Time: 09:19:48

PROJECT INFORMATION

Test Well: MW-110

Test Date: $10 / 23 / 12$

\section{AQUIFER DATA}

Saturated Thickness: $7.6 \mathrm{~m}$

Anisotropy Ratio (Kz/Kr): 1 .

WELL DATA (MW-110)

Initial Displacement: $2.4 \mathrm{~m}$

Total Well Penetration Depth: $18 \mathrm{~m}$

Static Water Column Height: 37 . m

Screen Length: $3 \mathrm{~m}$

Casing Radius: $0.025 \mathrm{~m}$

Well Radius: $0.05 \mathrm{~m}$

\section{SOLUTION}

Aquifer Model: Unconfined

Solution Method: Bouwer-Rice

$\mathrm{K}=2.022 \mathrm{E}-6 \mathrm{ft} / \mathrm{sec}$

$\mathrm{y} 0=\underline{1.211 \mathrm{~m}}$

Figure C-22: MW-110 Slug Test 


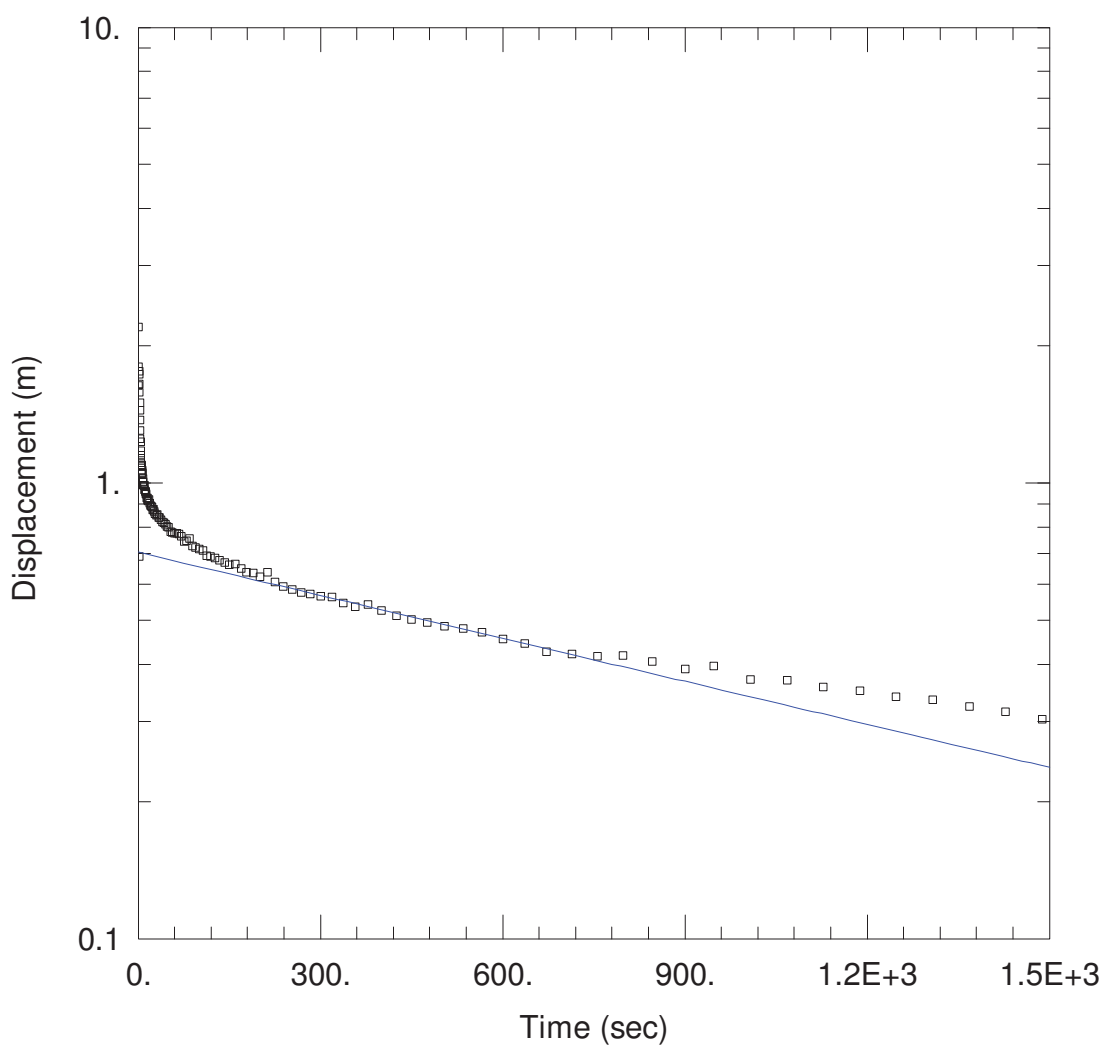

\begin{tabular}{|c|c|}
\hline \multicolumn{2}{|c|}{ WELL TEST ANALYSIS } \\
\hline $\begin{array}{l}\text { Data Set: P:I...MWW-111.aqt } \\
\text { Date: } \underline{03 / 07 / 15}\end{array}$ & Time: $\underline{09: 20: 13}$ \\
\hline \multicolumn{2}{|c|}{ PROJECT INFORMATION } \\
\hline \multicolumn{2}{|l|}{$\begin{array}{l}\text { Test Well: } \frac{\mathrm{MW}-111}{10 / 16 / 12} \\
\text { Test Date: }\end{array}$} \\
\hline \multicolumn{2}{|c|}{ AQUIFER DATA } \\
\hline Saturated Thickness: $\underline{20} \mathrm{~m}$ & Anisotropy Ratio (Kz/Kr): 1 . \\
\hline \multicolumn{2}{|c|}{ WELL DATA (MW-111) } \\
\hline $\begin{array}{l}\text { Initial Displacement: } 0.5 \mathrm{~m} \\
\text { Total Well Penetration Depth: } \underline{2.4 \mathrm{~m}} \\
\text { Casing Radius: } \underline{0.025} \mathrm{~m}\end{array}$ & $\begin{array}{l}\text { Static Water Column Height: } 2.4 \mathrm{~m} \\
\text { Screen Length: } 2.4 \mathrm{~m} \\
\text { Well Radius: } 0.05 \mathrm{~m} \\
\text { Gravel Pack Porosity: } \underline{0 .}\end{array}$ \\
\hline \multicolumn{2}{|c|}{ SOLUTION } \\
\hline Aquifer Model: Unconfined & Solution Method: Bouwer-Rice \\
\hline 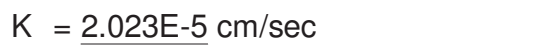 & $\mathrm{y} 0=\underline{0.214 \mathrm{~m}}$ \\
\hline
\end{tabular}

Figure C-23: MW-111 Slug Test 


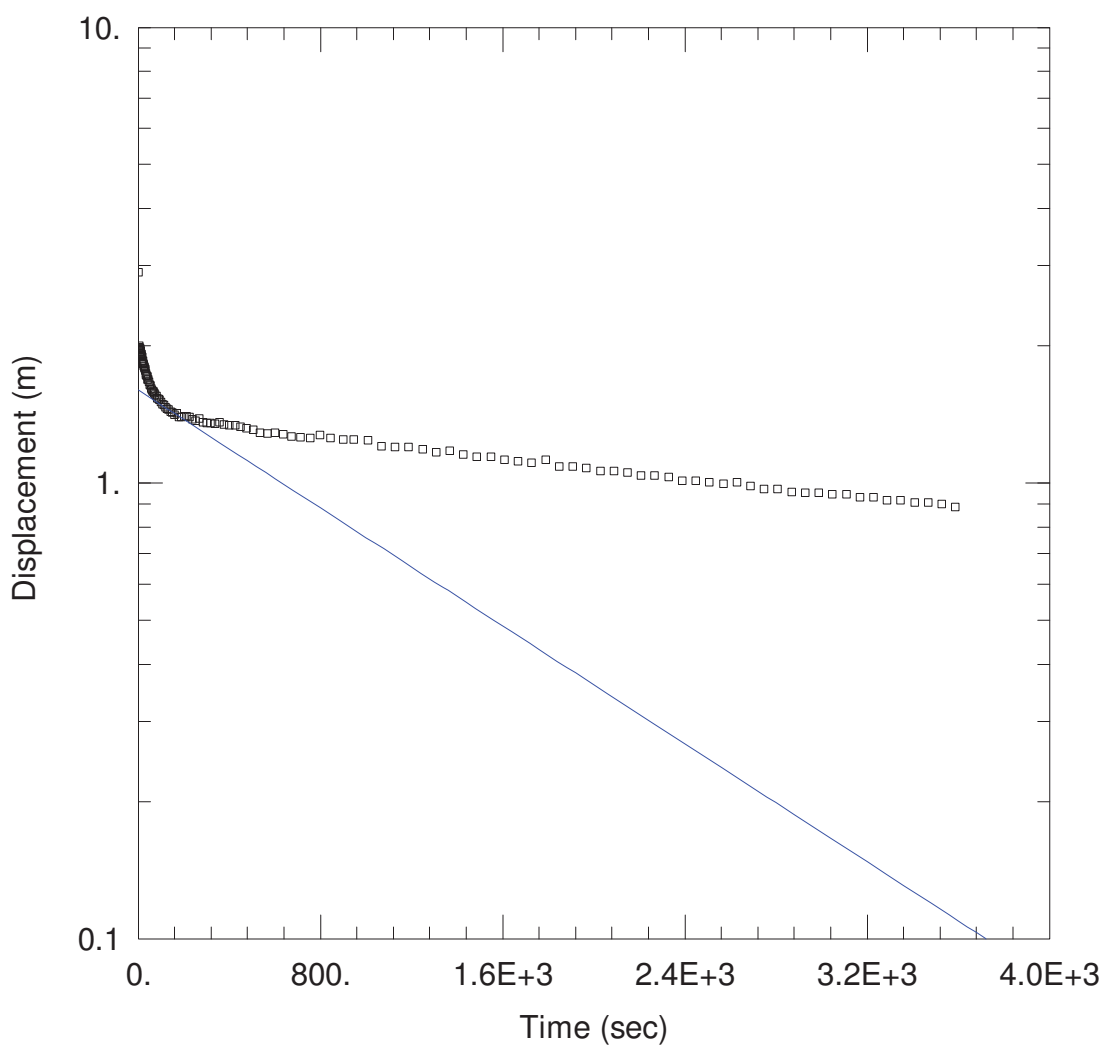

\begin{tabular}{|c|c|}
\hline \multicolumn{2}{|c|}{ WELL TEST ANALYSIS } \\
\hline $\begin{array}{l}\text { Data Set: } P: 1 . . . M W \text {-113.aqt } \\
\text { Date: } \underline{03 / 07 / 15}\end{array}$ & Time: $\underline{09: 20: 31}$ \\
\hline \multirow{2}{*}{\multicolumn{2}{|c|}{$\begin{array}{l}\text { Test Well: } \frac{M W-113}{10 / 23 / 12} \\
\text { Test Date: }\end{array}$}} \\
\hline & \\
\hline \multicolumn{2}{|c|}{ AQUIFER DATA } \\
\hline Saturated Thickness: $\underline{3.6 \mathrm{~m}}$ & Anisotropy Ratio (Kz/Kr): 1 . \\
\hline \multicolumn{2}{|c|}{ WELL DATA (MW-113) } \\
\hline $\begin{array}{l}\text { Initial Displacement: } 0.88 \mathrm{~m} \\
\text { Total Well Penetration Depth: } \underline{3.6} \mathrm{~m} \\
\text { Casing Radius: } \underline{0.025} \mathrm{~m}\end{array}$ & $\begin{array}{l}\text { Static Water Column Height: } \underline{4.2 \mathrm{~m}} \\
\text { Screen Length: } 3 . \mathrm{m} \\
\text { Well Radius: } 0.05 \mathrm{~m} \\
\text { Gravel Pack Porosity: } \underline{0 .}\end{array}$ \\
\hline \multicolumn{2}{|c|}{ SOLUTION } \\
\hline Aquifer Model: Unconfined & Solution Method: Bouwer-Rice \\
\hline 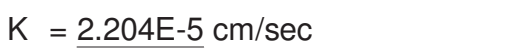 & $\mathrm{y} 0=\underline{0.48} \mathrm{~m}$ \\
\hline
\end{tabular}

Figure C-24: MW-113 Slug Test 


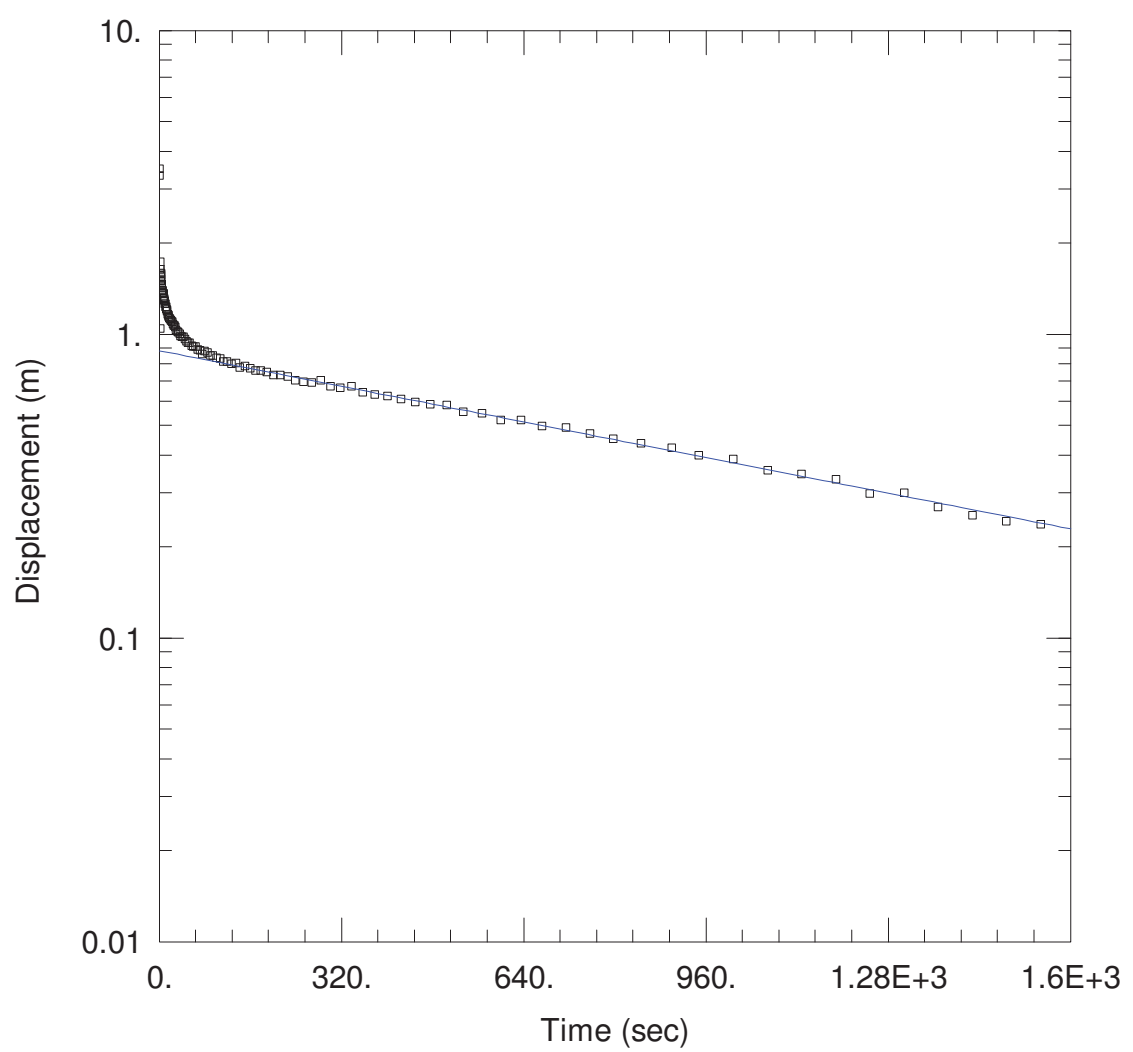

WELL TEST ANALYSIS

Data Set: $P:|\ldots| M W-114 A$.aqt

Date: $\underline{03 / 07 / 15}$

Time: 09:20:54

PROJECT INFORMATION

Test Well: MW-114A

Test Date: 10/23/12

\section{AQUIFER DATA}

Saturated Thickness: $\underline{4.5} \mathrm{~m}$

Anisotropy Ratio (Kz/Kr): 1.

WELL DATA (MW-114A)

Initial Displacement: $1.1 \mathrm{~m}$

Total Well Penetration Depth: $3.6 \mathrm{~m}$

Casing Radius: $\underline{0.025} \mathrm{~m}$

Static Water Column Height: $3.6 \mathrm{~m}$

Screen Length: $3 \mathrm{~m}$

Well Radius: $0.05 \mathrm{~m}$

Gravel Pack Porosity: $\underline{0 .}$

\section{SOLUTION}

Aquifer Model: Unconfined

Solution Method: Bouwer-Rice

$\mathrm{K}=2.257 \mathrm{E}-5 \mathrm{~cm} / \mathrm{sec}$

$\mathrm{y} 0=\underline{0.2688} \mathrm{~m}$

Figure C-25: MW-114A Slug Test 


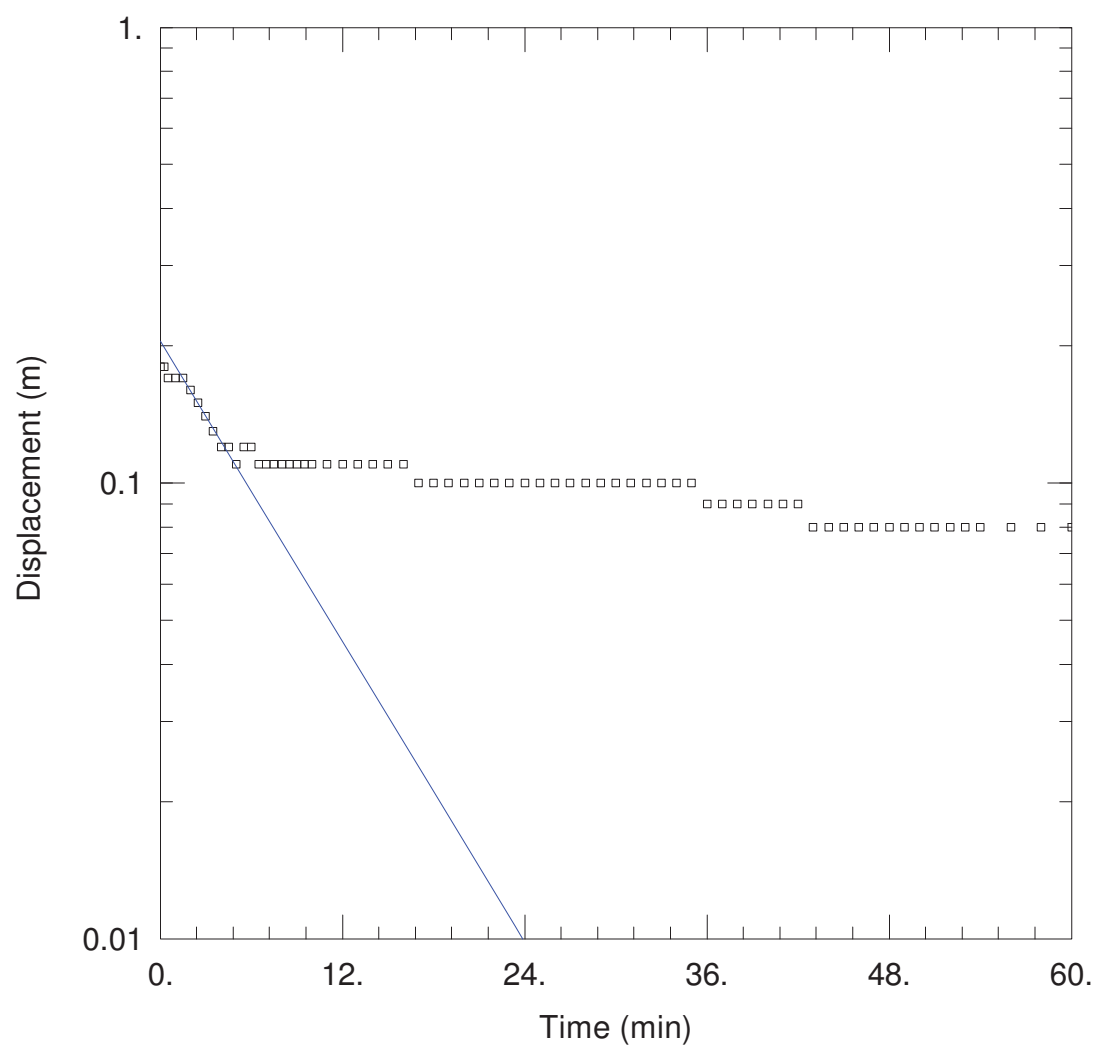

WELL TEST ANALYSIS

Data Set: P:I...MW-114B.aqt

Date: $\underline{03 / 07 / 15}$

Time: 09:21:11

PROJECT INFORMATION

Test Well: MW-114B

Test Date: 10/23/12

\section{AQUIFER DATA}

Saturated Thickness: $0.6 \mathrm{~m}$

Anisotropy Ratio (Kz/Kr): 1.

WELL DATA (MW-114B)

Initial Displacement: $\underline{0.05} \mathrm{~m}$

Total Well Penetration Depth: 34

Static Water Column Height: $\underline{0.22 \mathrm{~m}}$

Screen Length: 3. m

Casing Radius: $0.025 \mathrm{~m}$

Well Radius: $0.05 \mathrm{~m}$

\section{SOLUTION}

Aquifer Model: Unconfined

Solution Method: Bouwer-Rice

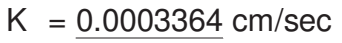

$\mathrm{y} 0=\underline{0.062 \mathrm{~m}}$

Figure C-26: MW-114B Slug Test 


\section{BIBLIOGRAPHY}

Avci, C. B., et al. "Evaluating the Effectiveness of Interceptor Trenches in Ground Water Pollution Control." Proc. 1992 Pet. Hydrocarbons Org. Chem. Ground Water: Prevent., Detect., Restor., Houston, Tex 315 (1992).

Bayer, Peter, and Michael Finkel. "Conventional and Combined Pump-and-Treat Systems Under Nonuniform Background Flow." Ground water 44.2 (2006): 234-243.

Bayer, P., Finkel, M., Teutsch, G. (2004). Combining Pump-and-Treat and Physical Barriers for Contaminant Plume Control, Ground Water, 42 (6), 856-867.

Damera, R., \& Bhandari, A. (2007). Physical Treatment Technologies. In Remediation Technologies for Soils and Groundwater (pp. 47-78). ASCE.

Davis, K. E. (1988). Laboratory evaluation of slurry wall materials of construction to prevent contamination of groundwater from organic constituents. Waste management \& research, 6(1), 201-215.

Deutsch, C.V., and A.G. Journel. (1992). GSLIB: Geostatistal Software Library and User’s Guide. New York: Oxford University Press.

Duda, Robert. "The Influence of Drainage Wells Barrier on Reducing the Amount of Major Contaminants Migrating from a Very Large Mine Tailings Disposal Site." Archives of Environmental Protection 40.4 (2014): 87-99.

EPA (U.S. Environmental Protection Agency) (1989). Evaluation of Groundwater Extraction Remedies, U.S. Environmental Protection Agency, Washington, DC.

Duffy, Glenn (2015). Aqtesolv Pro version 4.0. HydroSOLVE, Inc. 
Fetter, C. W. (2001). Applied hydrogeology. Upper Saddle River, NJ: Prentice Hall. FRTR (2001). Remediation Technologies Screening Matrix and Reference Guide 3.0, U.S. Environmental Protection Agency, Washington, DC.

Hornberger, R. J., Loop, C. M., Brady, K. B. C., \& Houtz, N. A. (2004). Geology of the Pennsylvania coal region. Coal ash Beneficial Use in Mine Reclamation and Mine Drainage Remediation in Pennsylvania. Pennsylvania Department of Environmental Protection and Penn State Materials Research Institute, 20-52.

Hudak, P. F. (2004). Augmenting groundwater monitoring networks near landfills with slurry cutoff walls. Environmental monitoring and assessment, 90(1-3), 113-120.

Hudak, P. F. (2005). Effect of setback distance on ability of gravel trenches to intercept contaminated groundwater. Environmental monitoring and assessment, 104(1-3), 419-423.

LaMaskin, T., Woodworth, A., Spangler, J., Welch, S. M., Sergi, S., \& Banks, T. (2003). Conceptual site model development for an unlined solid waste landfill in the Virginia coastal plain; evidence for natural attenuation of chlorinated solvents. Abstracts with Programs - Geological Society of America, 35(1), 3. Retrieved from http://search.proquest.com.pitt.idm.oclc.org/docview/51656879?accountid=14709

McDonald, M.G., Harbaugh, A.W. (1988). A modular three dimensional, finite difference groundwater flow model. U.S. Geological Survey Techniques of Water Resources Investigation, Book 6, Chapter A1.

McMurtry, D. C., \& Elton, R. O. (1985). New approach to in-situ treatment of contaminated groundwaters. Environmental Progress, 4(3), 168-170.

NRC (1994). Alternatives for Ground Water Cleanup. National Research Council. National Academy Press. 
Odunlami, Moradeyo Olabisi. Investigation of Groundwater Quality near a Municipal Landfill Site (IGQMLS). International Journal of Chemical Engineering and Applications. Vol. 3, No. 6, December 2012

Patterson, E., \& Lieu, J. (1971). Coal resources of Butler County, Pennsylvania. Washington: U.S. Govt. Print. Off. (Patterson, 1971)

Patterson, E. (1963). Coal resources of Beaver County, Pennsylvania. Washington [D.C.: U.S. G.P.O. (Patterson, 1963)

Rajapakse, R. (2011). Geotechnical engineering calculations and rules of thumb. ButterworthHeinemann.

Reddy, P. S., \& Nandini, N. (2011). Leachate characterization and assessment of groundwater pollution near municipal solid waste landfill site. Nature, Environment and Pollution Technology, 10(3), 415-418. Retrieved from http://search.proquest.com/docview/909939082?accountid=14709

Schmid, B., Van Everdingen, ,R.O., Maathuis, H. (2003). The Impact of the Creation of Lake Diefenbaker on Water Levels in Underlying Extensive Bedrock Aquifers; a 40-Year History. $5^{\text {th }}$ Canadian Geotechnical Convergence, $4^{\text {th }}$ Joint IAH-CNC/CGS Conference, 2003 NAGS Conference.

Seaber, Paul R., J. V. Brahana, and E. F. Hollyday. "Region 20, Appalachian plateaus and valley and ridge." The Geology of North America: Hydrogeology (1988): 189-200.

Van, T. D., Klein, N. H., Leggette, R. M., Pennsylvania, \& Geological Survey (U.S.). (1951). Ground-water resources of Beaver County, Pennsylvania. Harrisburg, PA: Pennsylvania, Bureau of Topographic and Geologic Survey.

Wildi, W. (2010). Environmental hazards of dams and reservoirs. Near Curriculum in Natural Environmental Science, 88, 187-197. 
Yadav, S. Muralidhar. Application of leachate pollution indices for assessment of leachate pollution potential of landfills. Int. J. Environment and Waste Management, Vol 13, No. 2, 2014.

Yeboah, N. N. N., \& Burns, S. E. (2011). Geological disposal of energy-related waste. KSCE Journal of Civil Engineering, 15(4), 697-705. 